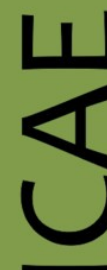

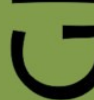

ex Instituto Archaeologico Universitatis de Rolando Eötvös nominatae

O

$\overrightarrow{0}$

山

$\leftarrow$

I

$\cup$

ه

$\leftarrow$

u

Ш

Z

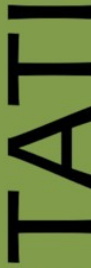

œ

ш

n

n

$\varnothing$
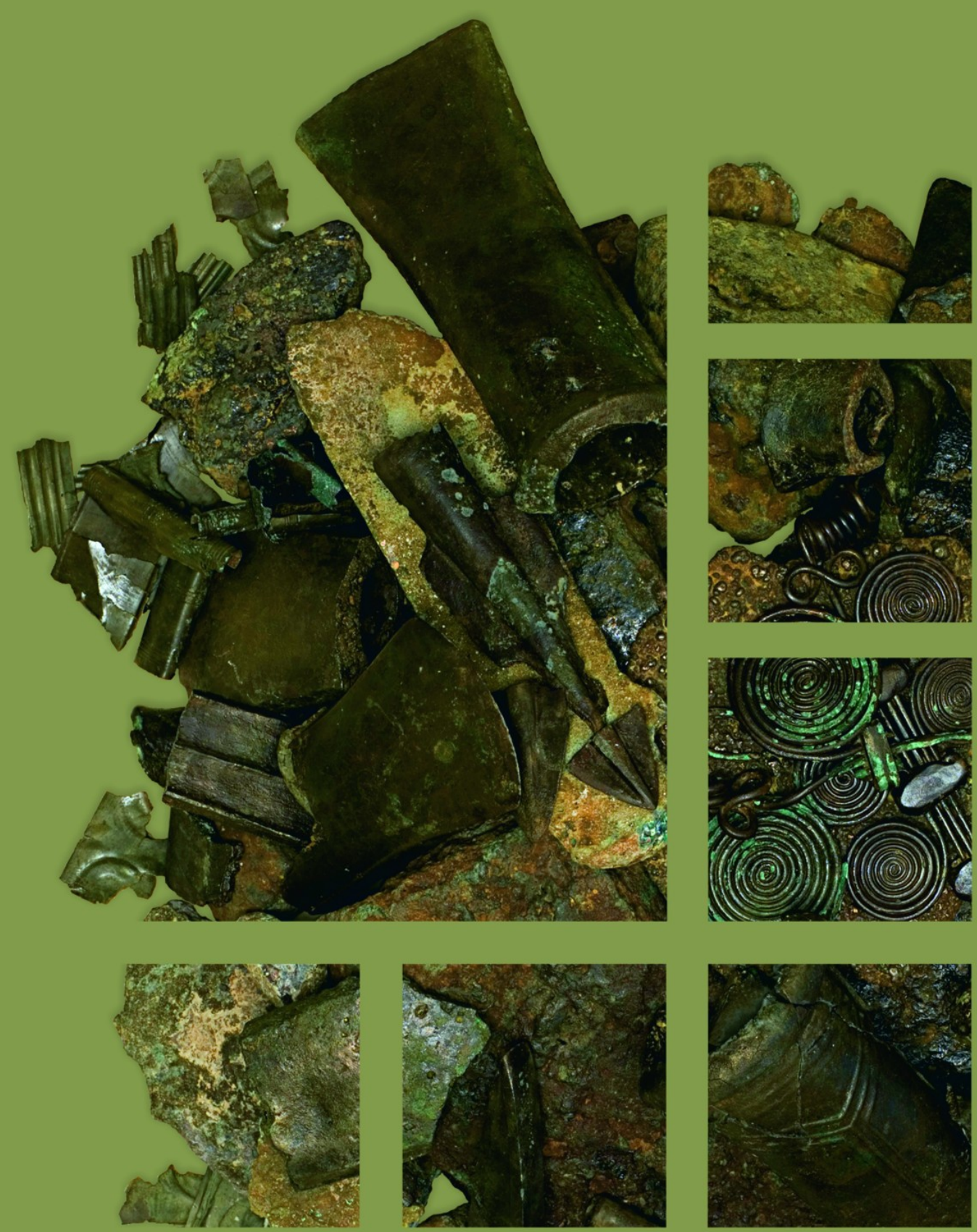


\section{Dissertationes Archaeologicae ex Instituto Archaeologico}

Universitatis de Rolando Eötvös nominatae Ser. 3. No. 2.

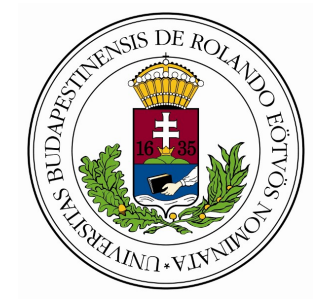

Budapest 2014 
Dissertationes Archaeologicae ex Instituto Archaeologico Universitatis de Rolando Eötvös nominatae

Ser. 3. No. 2.

Editor-in-chief:

DÁvid BARTus

Editorial board:

LÁsZló BARTOSIEWICZ

LÁSZLÓ BORHY

IsTVÁN FELD

GÁBOR KALLA

PÁL RACZKY

MiKLÓs SzABÓ

TIVADAR VIDA

Technical editors:

DÁvid BARTus

GÁBOR VÁCZI

ANDRÁs BÖDŐCS

DÁNIEL SZABÓ

Proofreading:

SZILVIA SzÖLLősI

Available online at http://dissarch.elte.hu Contact: dissarch@btk.elte.hu

$$
\begin{aligned}
& \text { PUBLIC } \\
& \text { KNOWLEDGE } \\
& \text { PROJECT }
\end{aligned}
$$

(c) Eötvös Loránd University, Institute of Archaeological Sciences

Budapest 2014 


\section{Contents}

\section{SElected PAPERS OF THE XI. Hungarian CONFERENCE on Classical Studies}

Ferenc BARNA

Venus mit Waffen. Die Darstellungen und die Rolle der Göttin in der Münzpropaganda

der Zeit der Soldatenkaiser (235-284 n. Chr.)

Dénes GABLER

A belsó vámok szerepe a rajnai és a dunai provinciák importált kerámiaspektrumában

Lajos MATHÉDESZ

Római bélyeges téglák a komáromi Duna Menti Múzeum gyújteményében

Katalin OtTOMÁNYI

Újabb római vicusok Aquincum territoriumán

Eszter SÜVEGH

Hellenistic grotesque terracotta figurines. Problems of iconographical interpretation

András SzABó

Some notes on the rings with sacred inscriptions from Pannonia

István VIDA

The coinage of Flavia Maxima Helena

\section{Articles}

Gábor TARBAY

Late Bronze Age depot from the foothills of the Pilis Mountains

Csilla SÁRó

Roman brooches from Paks-Gyapa - Rosti-puszta

András BöDőcs - Gábor KovÁcs - Krisztián ANDERKó

The impact of the roman agriculture on the territory of Savaria

Lajos JuHÁsz

Two new Roman bronzes with Suebian nodus from Brigetio

\section{FIELD REPORTS}

Zsolt MESTER - Norbert FARAGó - Attila KirÁLy

The first in situ Old Stone Age assemblage from the Rába Valley, Northwestern Hungary

Pál RACZky - Alexandra ANDERs - Norbert FARAgó - Gábor MÁRKus

Short report on the 2014 excavations at Polgár-Csőszhalom 
Preliminary Report on the first season of fieldwork in Berettyóúffalu-Szilhalom

Márton SzILÁgyi - András FüZESI - Attila VIRÁG - Mihály GASPARIK

A Palaeolithic mammoth bone deposit and a Late Copper Age Baden settlement and enclosure

Preliminary report on the rescue excavation at Szurdokpüspöki - Hosszú-dúlö II-III. (M21 site No. 6-7)

Kristóf FüLÖP - Gábor VÁcZI

Preliminary report on the excavation of a new Late Bronze Age cemetery

from fobbágyi (North Hungary)

Lőrinc TimÁr - Zoltán CzAJLik - András BöDőcs - Sándor PuszTA

Geophysical prospection on the Pâture du Couvent (Bibracte, France). The campaign of 2014

Dávid BARtus - László Borhy - Gabriella Delbó - Emese SzÁmadó

Short report on the excavations in the civil town of Brigetio (Szőny-Vásártér) in 2014

Dávid BARTus - László BorHy - Emese SzÁMADó

A new Roman bath in the canabae of Brigetio

Short report on the excavations at the site Szőny-Dunapart in 2014

Dávid BARTus - László Borhy - Zoltán CzAjlik - Balázs Holl -

Sándor PuszTA - László RuPNiK

Topographical research in the canabae of Brigetio in 2014

Zoltán CZAJLIK - Sándor BERECKI - László RUPNIK

Aerial Geoarchaeological Survey in the Valleys of the Mureș and Arieș Rivers (2009-2013)

Maxim MoRDovin

Short report on the excavations in 2014 of the Department of Hungarian Medieval

and Early Modern Archaeology (Eötvös Loránd University, Budapest)

Excavations at Castles Čabrad' and Drégely, and at the Pauline Friary at Sáska

\section{Thesis Abstracts}

Piroska Csengeri

Late groups of the Alföld Linear Pottery culture in north-eastern Hungary

New results of the research in Borsod-Abaúj-Zemplén County

Ádám Bíró

Weapons in the 10-11th century Carpathian Basin

Studies in weapon technology and methodology - rigid bow applications and southern import

swords in the archaeological material

Márta DARÓcZI-SzABó

Animal remains from the mid 12th-13th century (Árpád Period) village of Kána, Hungary

Károly BELÉNYESY

A 15th-16th century cannon foundry workshop in Buda

Craftsmen and technology of cannon moulding and the transformation of military technology

from the Renaissance to the Post Medieval Period 
István RINGER

Manorial and urban manufactories in the 17th century in Sárospatak

\section{BIBLIOGRAPHY}

László BORHY

565

Bibliography of the excavations in Brigetio (1992-2014) 


\title{
Late Bronze Age depot from the foothills of the Pilis Mountains
}

\author{
JÁNOS GÁBOR TARBAY \\ Institute of Archaeological Sciences \\ Eötvös Loránd University \\ tarbayjgabor@gmail.com \\ Hungarian National Museum \\ tarbay.gabor@hnm.hu
}

\begin{abstract}
The analyzed assemblage was found in 2008 by Gergely Radovics, in the vicinity of Kesztölc (Hungary, Komárom-Esztergom county). It consists of 107 artefacts (total weight: $12260.31 \mathrm{~g}$ ) which can be divided into nine groups based on their function: 1. weapons; 2. utensils; 3. clothing parts; 4. metal vessel; 5. wagon part; 7. semi-finished products; 8. metallurgical byproducts; 9. unclassifiable objects. The aim of this study is to give a complete evaluation of the artefacts in question by using the typo-chronological method and macroscopic observations. In addition, due to the finder's statement we were able to reconstruct the original context and re-localize the exact finding place.
\end{abstract}

\section{Introduction}

The study discusses a new Late Bronze Age depot from Kesztölc-Bodzás dülő (Hungary, Komárom-Esztergom county). The assemblage and one bit were found in 2008 by a local metal detectorist: Gergely Radovics. Two years later, he generously contributed to their publication and handled over the depot to Gábor V. Szabó and Gábor Lassányi. Thereafter these finds were temporarily stored at the Eötvös Loránd University, Institute of Archaeological Sciences for the purpose of documentation, restauration and evaluation. ${ }^{1}$ The depot consists of 107 artefacts (total weight: $12260.31 \mathrm{~g}$ ) which are classifiable into nine groups on the basis of their function: 1.) weapons: spears; 2.) utensils: socketed chisel, socketed axes, fragments of socketed utensils, fragments of flange-handled sickles; 3.) clothing parts: rings, belt, passementerie fibulae, torques, metal sheet tubes; 4.) metal vessel: Zateč-Type bucket, 5.) wagon part: tube with widened rim; 7.) semi-finished products: axe half form, rod ingot, plano-convex ingots; 8.) metallurgical byproducts: casting jets; 9.) unclassifiable objects: button/belt-hook, wire fragments (Fig. 1-2). The following chapters will concentrate on the topographical situation, finding circumstances, typo-chronological and technological aspects of the assemblage. Within the framework of the final chapter we shall discuss the depositional features and chronological questions of the analyzed assemblage.

1 The first evaluations of the artefacts were carried out as a part of my BA (2010) and MA (2013) thesis. TARBAY 2011; TARBAY 2013. In 2012, the two passementerie fibuae of the depot were published in a separate study. TARBAY 2012. Shortly after, the results of these works were briefly presented by Gábor V. Szabó. V. SzABó 2013, 808-809, Fig. 14. The present publication was supported by the Hungarian Scientific Research Fund (OTKA K 112 427). 


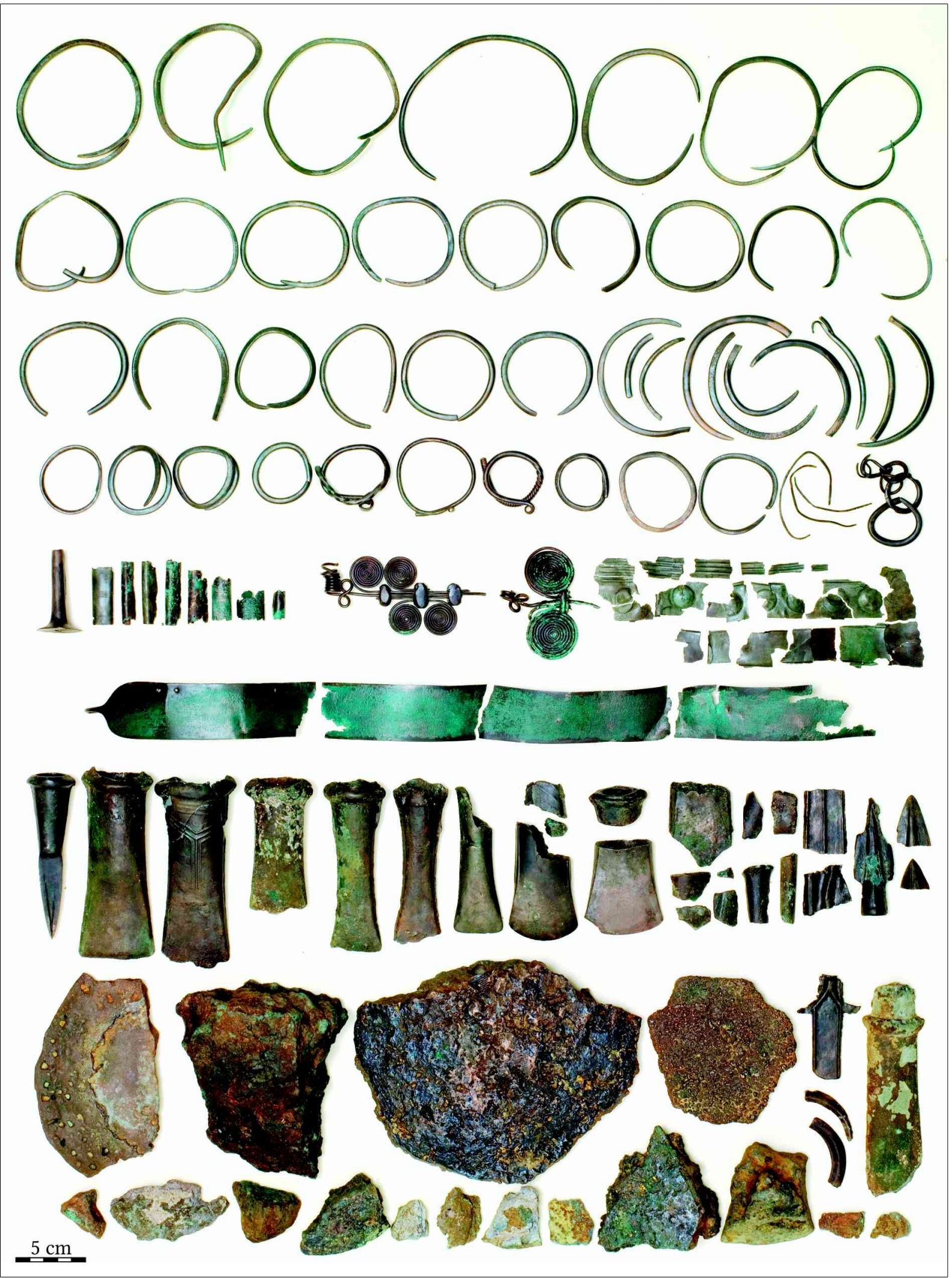

Fig. 1. Late Bronze Age depot from Kesztölc. 


\section{Topographical Situation}

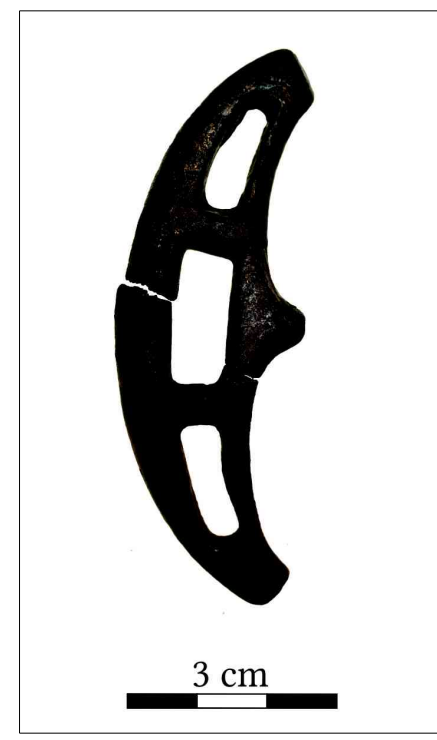

Fig. 2. The stray find fom Kesztölc.

The village of Kesztölc is located at the northwestern slope of the Pilis Mountans. The topography of the area is dominated by intervening valleys and the Kenyérmezo stream that flows in curving path from northern to the southern boundary of the region. The communities of the Transdanubian Urnfield sphere had already settled the area during the Late Bronze Age. In the recent half century, many ceramics and bronze artefacts came to light in the vicinity of Kesztölc (List 1). The most prominent of these discoveries is the cemetery of Cseresznyés hát which is topographically close to the finding place of the analyzed depot. The first graves were excavated at the end of the 1950s, at the southern slope of the site. Later, in the 1960s, G. Szepessy found some characteristic Urnfield ceramics. During the construction of the kindergarten at the Eastern part of the site, five graves with typical Urnfield pottery were excavated. Newer finds had unearthed during the village's road construction, and later they were donated to the Balassa Bálint Museum by P. Kárpáti. It is important to mention the results of É. V. Vadász's excava tions when 13 new graves were salvaged. Symbolic burials (No. 1-2) and burials with stoneand-pile construction were also found at that time. The burials contained typical Urnfield ceramics, animal bones and even small bronze jewelries. ${ }^{2}$ It should be emphasized that these finds were dated to the Ha A2 stage by E. Patek which is chronologically close to the deposition of the analyzed assemblage. ${ }^{3}$ Further notable sites are the Sármánka and Chlapec caves where Late Bronze Age ceramics were also found. ${ }^{4}$ The topographically closest metal finds to the depot are a chisel and a socketed axe which were unearthed in the territory of the Sátorko sand mine at Dorog (List 1). ${ }^{5}$ It should be underlined that the Kesztölc depot is the only prominent metal assemblage from this area. However, depots ${ }^{6}$ with similar dating (Ha A1 - Ha A2) and composition, moreover river finds are known from the wider geographical region of the Danube Bend, Nitransky kraj, Komárom-Esztergom and Northern part of Pest county (Fig. 3).

The exact finding place is located at Bodzás dülö - an uncultivated land -, in a northwestern direction from Kesztölc village, next to the road 117th (Fig. 4-6). ${ }^{7}$ Since 2008, G. Radovics has been investigating the site many times, but according to his statement, he did not find further metal or ceramic artefacts. The first field survey was carried out in 2010 when we searched not just the finding place but the Cseresznyés hát and Sármánka cave as well. As a result of this attempt, only a few untypical ceramics were collected from the surface of the Sármánka cave. In April 2011, metal detector reconnaissance was carried out in Bodzás dűlő which was led by G. V. Szabó. Due to weather conditions, the investigation only lasted for a

\footnotetext{
2 Horvát et Al. 1979, 238; Patek 1968, 74, 126-128, Taf. CVIII. 6-11, Taf. CIX. 4-12.

3 PATEK 1968, 74, 126-128.

4 Horvát et AL. 1979, 239, 300-302.

5 Horvát ET AL. 1979, 64.

6 The most important assemblage is the depot from Esztergom-Szentgyörgymező which was dated to the Ha A1 stage and composed of similar artefacts (e. g. fragments of Žatec-type bucket and a belt) as the Kesztölc depot. HoRvÁt ET AL. 1979, 212, 19-20. tábla; Mozsolics 1985, 117-118, Taf. 137-138.

7 The finding place was located by the aid of the finder. Due to the present day illicit metal detector activities, we do not intend to publish here the site's exact GPS coordinates.
} 
few hours, but two smaller bronze lumps came to light from the exact location of the depot. Unfortunately, further metal objects or datable ceramics were not found. In the following years, the finding place were investigated two more times but similarly to the previous ones, no datable artefacts appeared in Bodzás dülő.

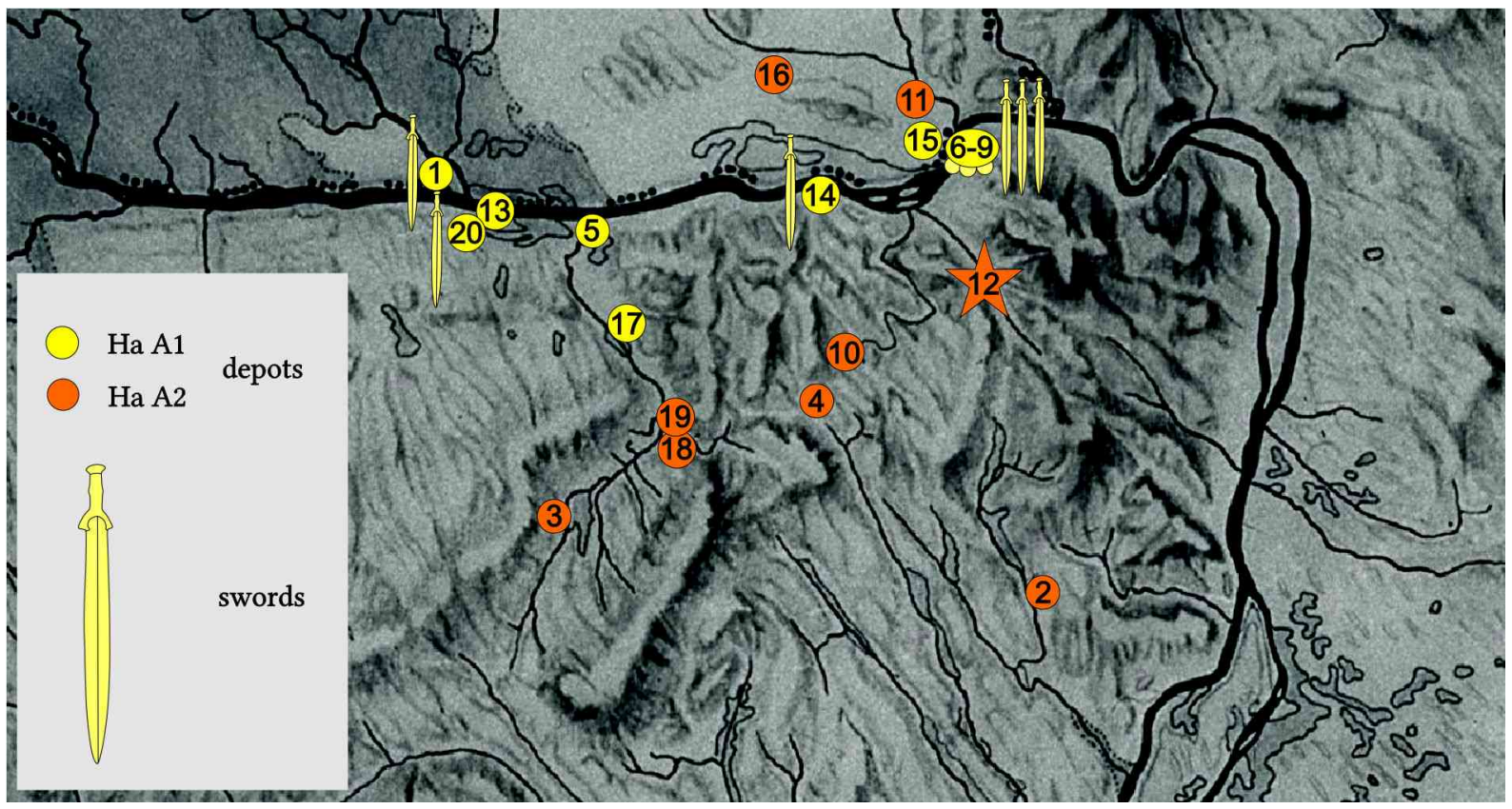

Fig. 3. Depots and individual sword finds from North Eastern Transdanubia (Hungary, Komárom-Esztergom, Pest county) and Southern Slovakia (Nitriansky kraj) between the Ha A1 and Ha A2 stages. 1. Ács; 2. Biatorbágy-Herceghalom; 3. Bokod; 4. Csabdi; 5. Dunaalmás; 6. Esztergom-Szentgyörgymező; 7. Esztergom-Dunahíd 1; 8. Esztergom-Dunahíd 2; 9. Esztergom-Dunahíd 3; 10. Gyermely-Szomor; 11. Kammený Most; 12. Kesztölc; 13. Komárom; 14. Nyergesújfalu; 15. Śtúrovo; 16. Strekov; 17. Tata; 18. Tatabánya-Bánhida; 19. Tatabánya-Ótelep; 20. Újszőny. Kemenczei 1996, 77-78; Mozsolics 1985, Taf. 280-281; Novotná 1970a.

The aim of the preliminary field surveys were the precise investigation of the site. It can therefore be concluded that the depot was the only Late Bronze Age metal assemblage in Bodzás dülö. It is worth to mention that during spring rains the site become marshy wetland. Moreover it is topographically close to the Cseresznyés hát cemetery which is separated by the eastern branch of the Kenyérmező stream. This promising geographical situation $^{8}$ should be investigated later by extensive metal detector reconnaissance and other field survey methods (Fig. 4, Fig. 7).

\section{The reconstruction of the context}

The exact find circumstances of the depot were not documented by archaeologists, therefore the following information only rely on the oral statement of the finder (Fig. 8). G. Radovics first discovered a ring and shortly afterwards, not further away the depot, which was buried approximately $40 \mathrm{~cm}$ deep under the present surface without any trace of organic residue. According to his statement, it composed of three separated parts: a central heap and two, separate heaps of rings. The plano-convex ingots were in the lowest section of the central heap.

8 It should be emphasized that the landscape of Kesztölc has changed radically. In the recent century, the village expanded northwards, new artificial lakes were created and stone mining was conducted at the Fehér-szirt. 


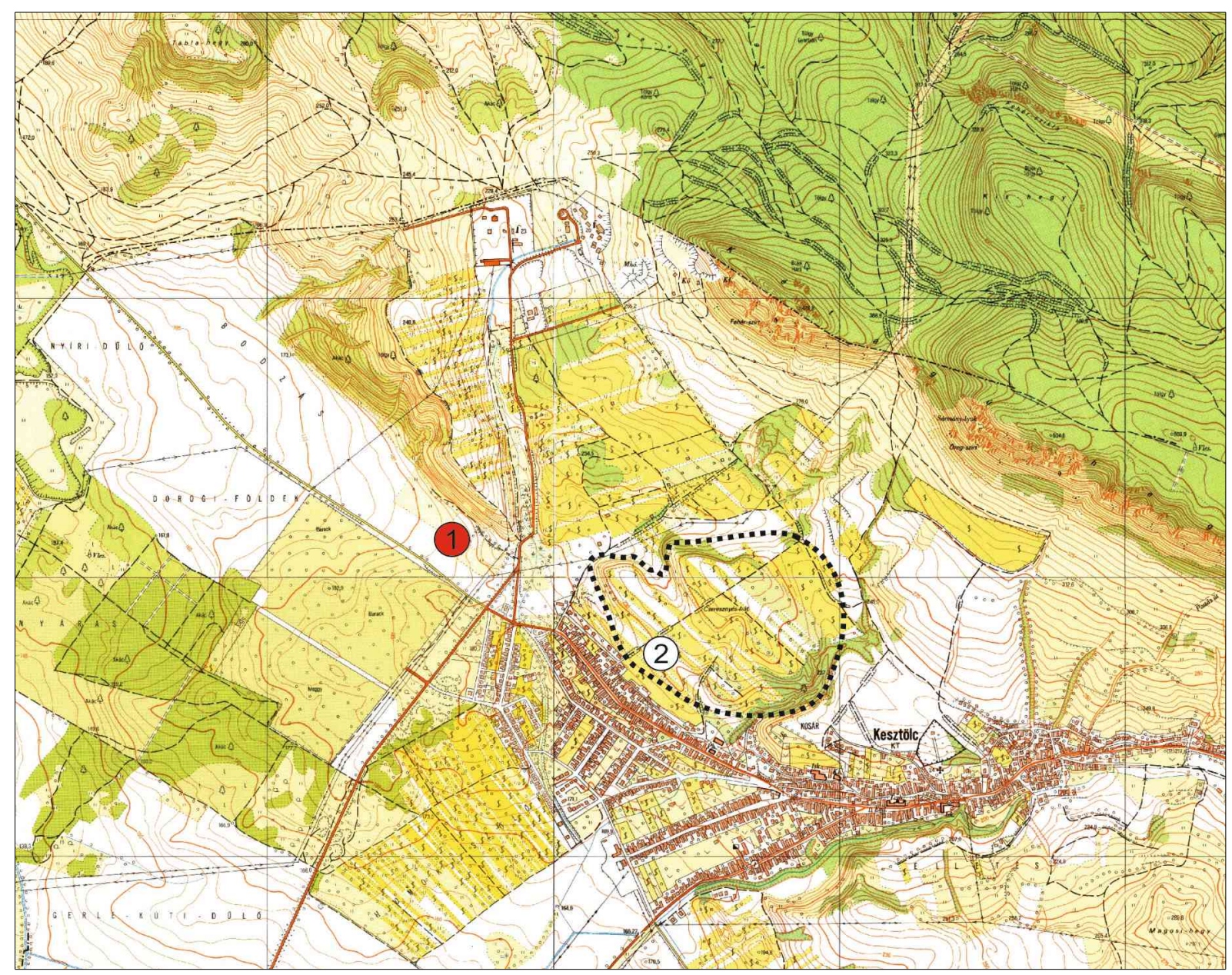

Fig. 4. The location of the depot (1) and the Cseresznyés hát (2).

On the top of them a chisel and socketed axes were buried randomly. The passamenterie fibulae which was the first appeared objects, situated on the highest section. It is important to note that the central heap was surrounded by the fragments of the belt. The chained objects and the rings were "separated by dimensions" and placed on the both sides of the central heap. Unfortunately, G. Radovics did not remember the position of the other artefacts, but his statement made it possible to reconstruct the probable, original context (Fig. 8, Fig. 44). In conclusion, the depot might be buried layered and deliberately organized. The valuable, damaged objects - such as the passementerie fibulae and the sheet belt - were positioned on special parts of the heaps. The less vulnerable artefacts - like the plano-convex ingots and the socketed utensils - were placed on the lower sections. Although we were unable to differentiate the rings by dimensions, their separate position is also notable. Despite its uncertainty, this reconstruction could provide valuable information about the deposition practices of the Carpathian Basin due to the extremely low number of assemblages with fine documentation or reconstructed context; not just in this region, but also in the whole territory of the Late Bronze Age Europe. ${ }^{9}$ We shall return to discuss the context within the framework of the final chapter. 

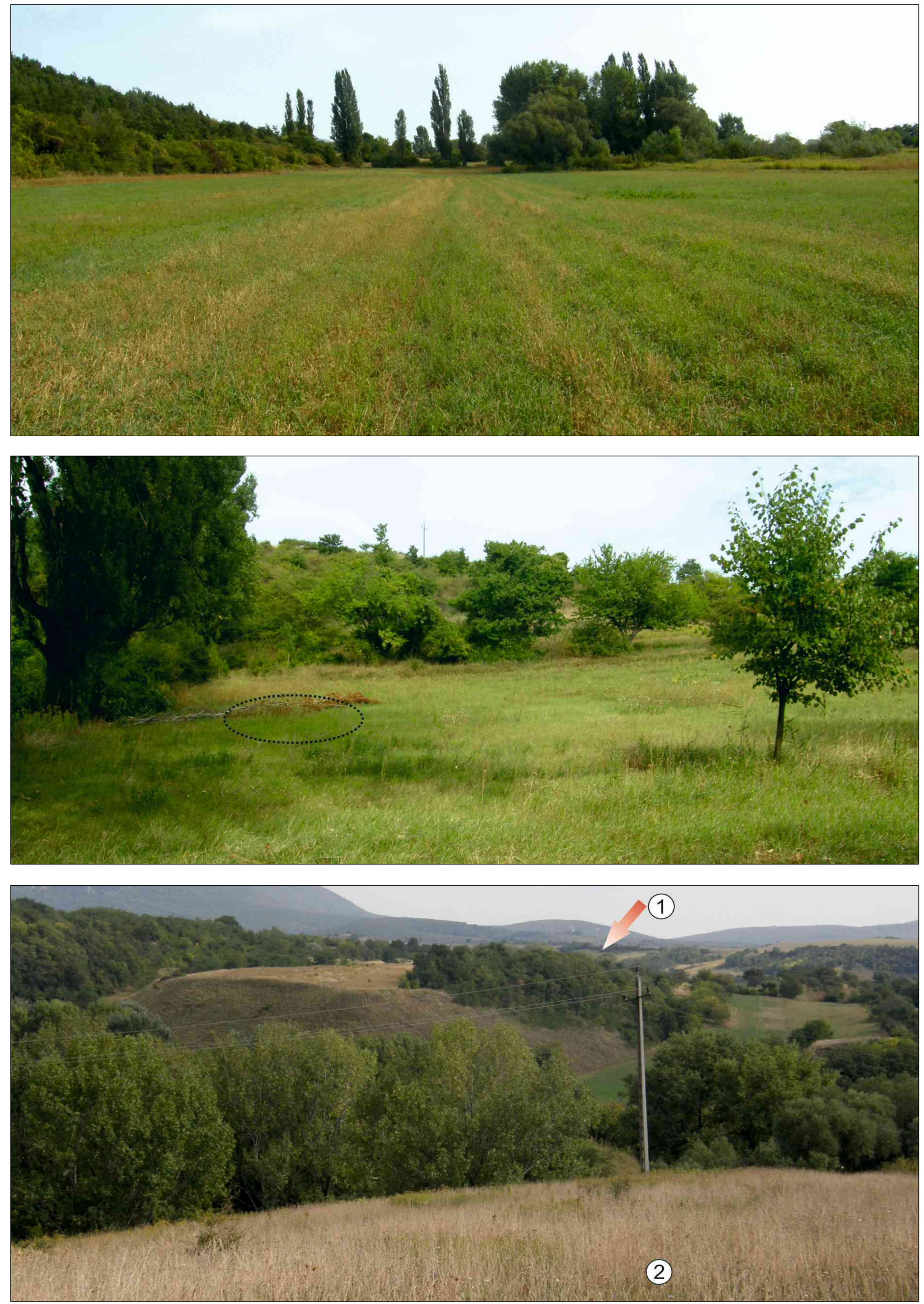

Fig. 5-7. Bodzás dủlő (above); The exact location of the finding place (center); The view to the Cseresznyés hát (1) from the hill next to Bodzás dủlö (2) (below). 


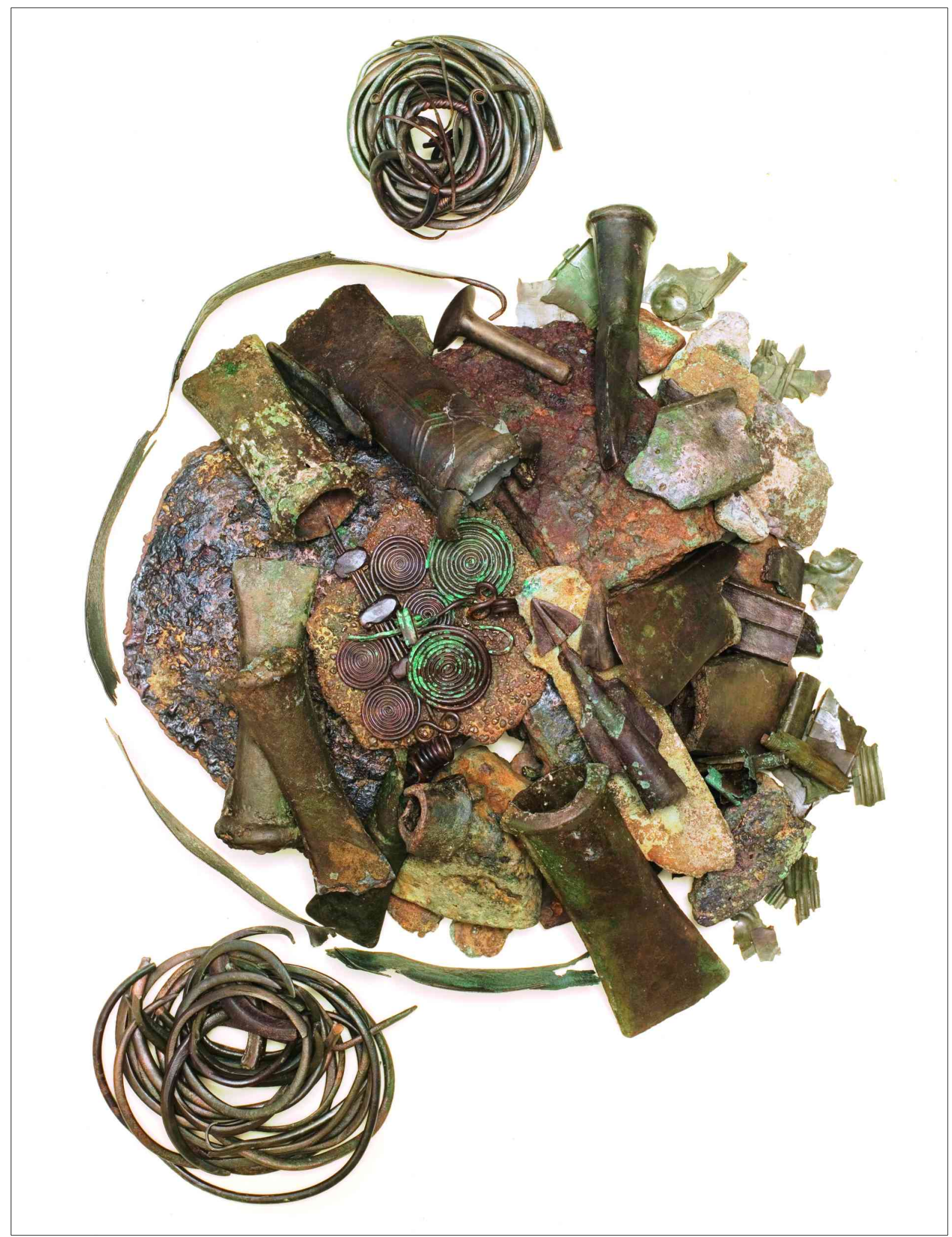

Fig. 8. The reconstruction of the context. 


\section{The Analysis of the Artefacts}

This chapter presents the summarized results of my MA thesis ${ }^{10}$ and primarily focuses on the evaluation of the artefacts in terms of typology, chronology, technology and probable function. The method of this analysis follows the works of Ch. Clausing, M. Hagl and B. Wanzek. ${ }^{11}$ In certain cases (e. g. the axe half-forms), more detailed analysis will be given by the reason of the lack of typology or the necessity for new synthesis. For the typo-chronological analysis we determine the closest stylistic and morphological parallels but we also take into account the spatial distribution and chronological aspects of the wider group of the analyzed artefacts. Each section is supplemented with distribution maps and lists of parallels which can be found in the Appendix (List 2-List 20). In the case of macroscopic observation, we used high resolution pictures and partly rely on the results of prominent, earlier studies. ${ }^{12}$

III. 1. Spears (Fig. 45.1-3)

The depot contains a spear with fragmented edge and two further blade fragments. From the beginning of the 19th century until the present day special attention has been paid on the typology and chronology of the spears, lances and sauroters. ${ }^{13}$ However, detailed typochronological evaluation of these weapons from the territory of Hungary and the Carpathian Basin basically remained undeveloped. As several researchers pointed out, this problem rooted not just in the deficiencies of the archaeological documentations, but also in the weapon under study itself which individualistic forms and decorations are hard to classify or interpret by the aid of traditional archaeological methods. ${ }^{14}$ This uniqueness is not surprising because the spears are very personal hunting-and fighting weapons. Moreover some may argue that they had also symbolic role among the Bronze Age societies. Therefore, the stylistic and formal diversity of the spears and lances may reflect on these special fighting styles, meanings or social behavioral patterns. Consequently, their exact function cannot be fully understood by only studying different stylistic and formal patterns of the weapons metal part. ${ }^{15}$ However, new technological and archaeo-metallurgical approaches based on experiments and systematic macro- and microscopic observations - may be able to construct new synthesis and answer to socio-historical questions. ${ }^{16}$

From typological point of view, only the spear No. 1 is suitable for further analysis. ${ }^{17}$ Due to the blade's deformation the original form is hard to reconstruct, only the short conical socket is visible. However, it is possible that the shape of the blade was originally a narrow, sub triangular form with angular base. ${ }^{18}$ Similar spears can be found among J. Ríhovský's typological scheme. ${ }^{19}$

10 TARBAy 2013, 42-172.

11 Clausing 2003; Hagl 2008; Wanzek 1992.

12 Bruno 2012, 203-279; Mozsolics 1984; Ottaway - Roberts 2003; Szabó 2013, 49-61.

13 Avila 1983; Bader 2006; 2009; Clausing 2005, 48-61; Dergačev 2002, 131-133; Foltiny 1955, 76-78; Gavranović 2011, 123-129; GedL 2009; HAMPEL 1896, 104-107; HANSEN 1994, 59-82, Abb. 34-35; HARDING 2007, 77-78; HöckMANN 1980; Hetesi 2004; Jacob-Friesen 1967a; Kobal' 2000, 31-33; Leshtakov 2011; Mozsolics 1967, 61-62; 1973, 33-34; 1985, 20-24; Ŕ́́HOVSKÝ 1996; TAROT 2000.

14 Hansen 1994, 59; Mozsolics 1985, 20.

15 Anderson 2011, 599-600; Clausing 2005, 59-60; ČIVIlyté 2009, 64; HaRding 2007, 77-78; LAUX 1971, 85; MozsoliCs 1985, 20-23; Mödlinger 2011, 54-55; Ř́́hovský 1996, 5; TARot 2000, 40-49.

16 ANDERSON 2011; BRUNo 2012, 216-232.

17 The No. 1 object, based on its dimensions can be classified into the group of spears. Its length is $8.5 \mathrm{~cm}$ which correlates with the dimensions of the Ríhovský's $(10-11 \mathrm{~cm})$ and Leshtakov's $(6-15 \mathrm{~cm})$ spear groups. It should be noted that this category is only a typological group and not a functional determination. LESHTAKOV 2011, 26-43; Ř́nOVSKÝ 1996, 88.

18 Grateful thanks are due to Tiberius Bader for his advices about the original form of the spear.

19 Ř́íHovskÝ 1996, 90-91. 
By the reason of the absence of detailed typo-chronological system, here we only focus on the closest parallels of the object. ${ }^{20}$ Similar weapons are known from the inner territory of the Carpathian Basin and from the southeastern part of the Czech Republic (e. g. Dubany). The dating of these spears is the Ha A2 stage in Hungary, however, in other countries of Central Europe this form is mainly dated to the Ha B1. It is important to note that comparable objects could also have been deposited in the Ha B2 stage (e. g. Hida) (Fig. 9, List 2). ${ }^{21}$

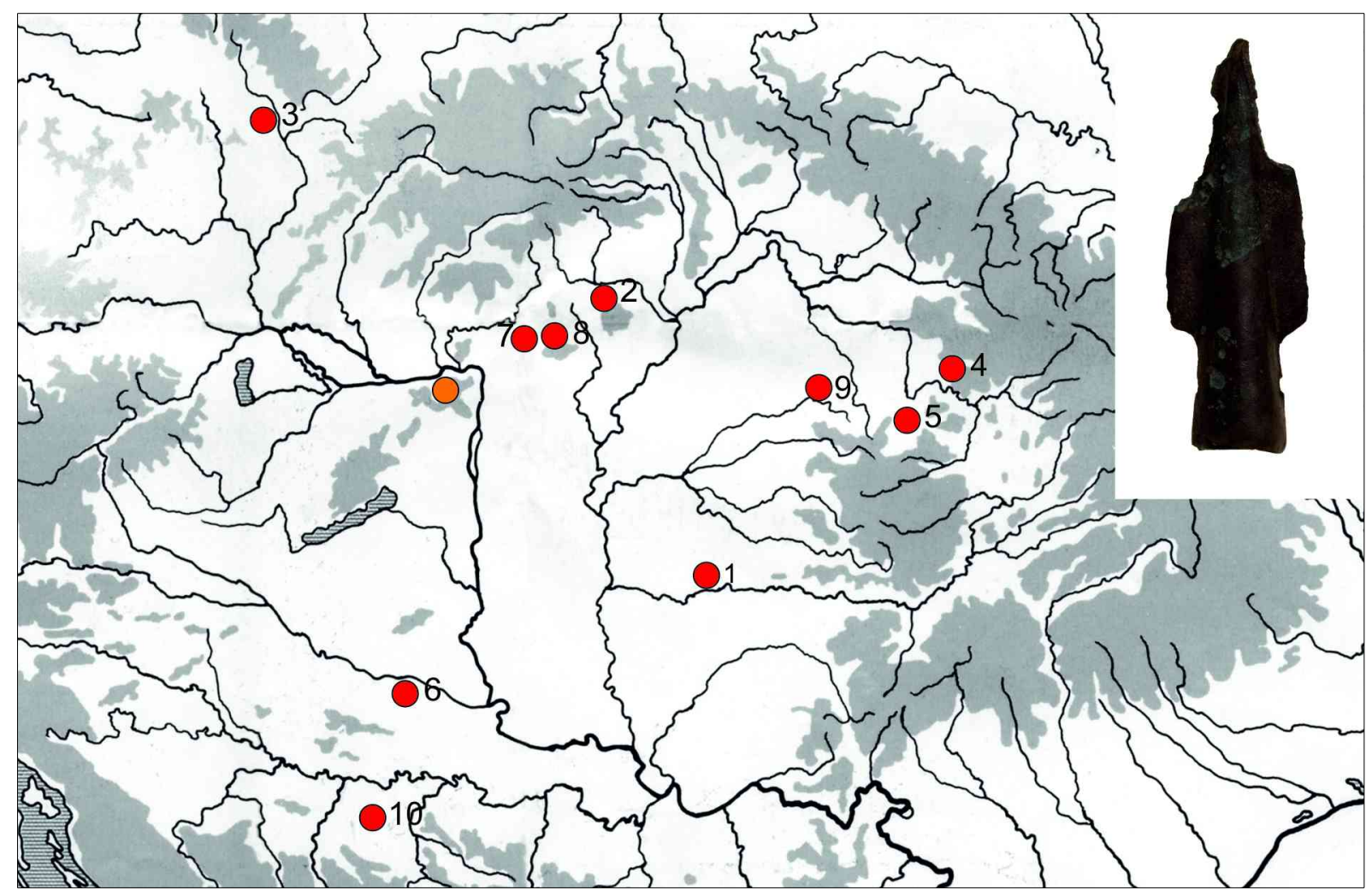

Fig. 9. The distribution of the parallels of the No. 1 spear (List 2).

The macroscopic observations of the three spears from Kesztölc provided interesting results. None of them bare traces of casting faults on their break surfaces. Although the corrosion and fragmentation damage to spear No. 1 is extensive, rendering the identification of further use-wear along its edges basically impossible. The current state of the fragment No. 2 is possibly the result of peri-depositional bending, moreover an oval damage mark is visible along its central rib. These two damage types may be connected, and thereupon they could be interpreted as traces of deliberate, prehistoric destruction. ${ }^{22}$ It is important to note that sharpening was also observed on blades of the fragments No. 2-3 which could support their use.

III. 2. Socketed axes (Fig. 46.4-5, Fig. 47.6-7, Fig. 48.8-9, Fig. 49.1O-11, Fig. 50.12-13, Fig. 51.14-17)

The Kesztölc depot contains eleven fragments of socketed axes which belong to a characteristic axe group of the Carpathian Basin. Based on the results of the traditional and experimental research, similar utensils were primarily interpreted as multi-functional objects.

20 The closest parallels were determined by the following criteria: 1.) length: $8.5-10 \mathrm{~cm}$; 2.) narrow, sub triangular blade with angular base; 3 .) cylindrical-sectioned socket; 4.) short, conical socket.

21 Petrescu-Dîmboviţa 1978, 149, Taf. 260.26.

22 Similar traces of destruction were observed by G. Szabó, B. Rezi and M. Novák. Novák - VÁczi 2012, 112; REzi 2011, 316; SzABÓ 1993, 199. 
They could be used as weapons or working tools, moreover their symbolic aspect is also possible. ${ }^{23}$ From the very beginning of the 19th century, the research has inherently focused on the typo-chronology of these artefacts. After J. Hampel's first discussion, several local typo-chronologies have been formulated. As a result of these studies, the fine chronology of the axes was established, based on mainly their stylistic features. ${ }^{24}$ Prominent examples are A. Mozsolics's works which she classified the socketed axes from the territory of Hungary, based on their fine features like the types of mouth, cross-sections or decorations. Her works have manifested great powers of survival, although now some of their results are outdated. ${ }^{25}$ In 1989, B. Wanzek wrote his classical monograph on the socketed axe moulds. Within the framework of his study he established the most detailed style-typology of the socketed axes from the Central-European region. ${ }^{26}$ Thereafter only local typo-chronologies and thematic studies have been written. ${ }^{27}$

\begin{tabular}{|c|c|c|}
\hline No. & Citations & Hungarian and German terminology \\
\hline 1. & HAMPEL 1886a, XI. Tábla. & Tokos vésők füllel, 1 . változat \\
\hline 2. & Foltiny 1955, 87-90. & $\begin{array}{l}\text { c) Tüllenbeile mit plastischer Verzierung ohne Öse d) Tül- } \\
\text { lenbeile mit plastischer Verzierung und Öse }\end{array}$ \\
\hline 3. & VON BRUNN 1968, 47, Abb. 3.30. & Beil mit geknickten Rippen \\
\hline 4. & VINSKI-GASPARINI 1973, 206. & Tüllenbeile mit plastischer V-Verzierung \\
\hline 5. & NovotnÁ 1970b, 83-87. & $\begin{array}{l}\text { Tüllenbeile mit Gerade Abschliessender Tülle Mitteleu- } \\
\text { ropäische Art }\end{array}$ \\
\hline 6. & MAYER 1977, 192. & Tüllenbeile mit Winkel-oder Bogenverzierung \\
\hline 7. & KEMENCZEI 1984, 53. & Tüllenbeile mit Rippenverzierung \\
\hline 8. & KEMENCZEI 1996, 76, 77, 78. & Tüllenbeile mit geknicktem Rippenornament \\
\hline 9. & Mozsolics 1985, 26. & Tüllenbeile mit Y-Rippen \\
\hline 10. & WANZEK $1989,106-109$. & 2.b.6.a. \\
\hline 11. & ŘíHOVsKy 1992, 203-205. & $\begin{array}{l}\text { Gruppe VIII: Mitteldonauländische Formen mit Reicher } \\
\text { Rippenzier und Keilförmigen Längsschnitt. }\end{array}$ \\
\hline 12. & ŽERAVICA 1993, 96, 99. & Verzierte Tüllenbeil, Variante 4 \\
\hline 13. & KoBAL' 2000, 41. & Beile Type 2, Variante A3 \\
\hline 14. & DERGAČEV 2002, 174, 176, Taf. 127. & Tüllenbeile vom Typ Debrecen \\
\hline 15. & KÖNIG 2004, 92, 101. & Tüllenbeile mit genickten Rippen \\
\hline 16. & $\begin{array}{l}\text { GAVRANOVIĆ 2011a, 134-135, 138- } \\
140 .\end{array}$ & $\begin{array}{l}\text { Frühe Tüllenbeile mit genickten/gebogenen Rippen, Tüllen- } \\
\text { beile mit Y-Rippe und gebogenen/genickten Seitenrippen. }\end{array}$ \\
\hline 17. & $\begin{array}{l}\text { BOROFFKA - RIDICHE 2005, 150, Liste } \\
\text { 8B3, Abb. 8.C9. }\end{array}$ & 2.b.6.a.3-1/3. \\
\hline
\end{tabular}

Fig. 10. Distinct terminologies of the "ribbed" socketed axes (No. 4 and No 15).

The classifiable socketed axes of the depot can be divided into two, distinct groups: 1.) socketed axes with straight body and thickened mouth (No. 4-7, 15); 2.) socketed axes with narrow, curve body and thickened mouth (No. 7, 9-10). ${ }^{28}$ It should be emphasized that group 1 is a widespread axe type. Despite it has many variants, all of them practically bare the same formal and stylistic features. ${ }^{29}$ Nonetheless, similar axes have been evaluated in different

23 EOgAN 2000, 8-9; EŐRY 1998-1999; KuŚNIERZ 1998, 6; MAYER 1977, 207; MONTAGEAGUdo 1977, 242; MÖDLINGER 2011, 51-53; Nienhuis et AL. 2011, 47-50, 60-61; Novotná 1970b, 71; Sprockhoff 1941, 92.

24 Hampel 1886a, 42-46; Foltiny 1955, 86-93; KibBert 1984; MAYer 1977; Mozsolics 1973, 37-41; 1985, 32-38; NovotnÁ 1970a, 44-47; 1970b.

25 Mozsolics 1973, 37-41; 1985, 32-38, Taf. 275; 2000, 24.

26 WANZEK 1989, 13-14.

27 BoroffKa - Ridiche 2005; Dergačev 2002, 136-143; Gavranović 2011, 128-146; KobaL' 2000, 39-43; Kuśierz 1998; Kytlicová 2007, 132-139; PÁszThory - MAYer 1998; Ř́íhovskÝ 1992; ŽERAVicA 1993, 74-106.

28 Due to their fragmentary state No. 12, 13, 14, 16 and 17 are not classifiable.

29 DergačEv 2002, 174-176, Taf. 127; KöNIG 2004, 101. 
kinds of local typological schemes, and published under several names, even though they belong to one, standard group (Fig. 10). The common characteristics of these works are the overemphasis of the ribbed decorations, from typological and chronological point as well. ${ }^{30}$

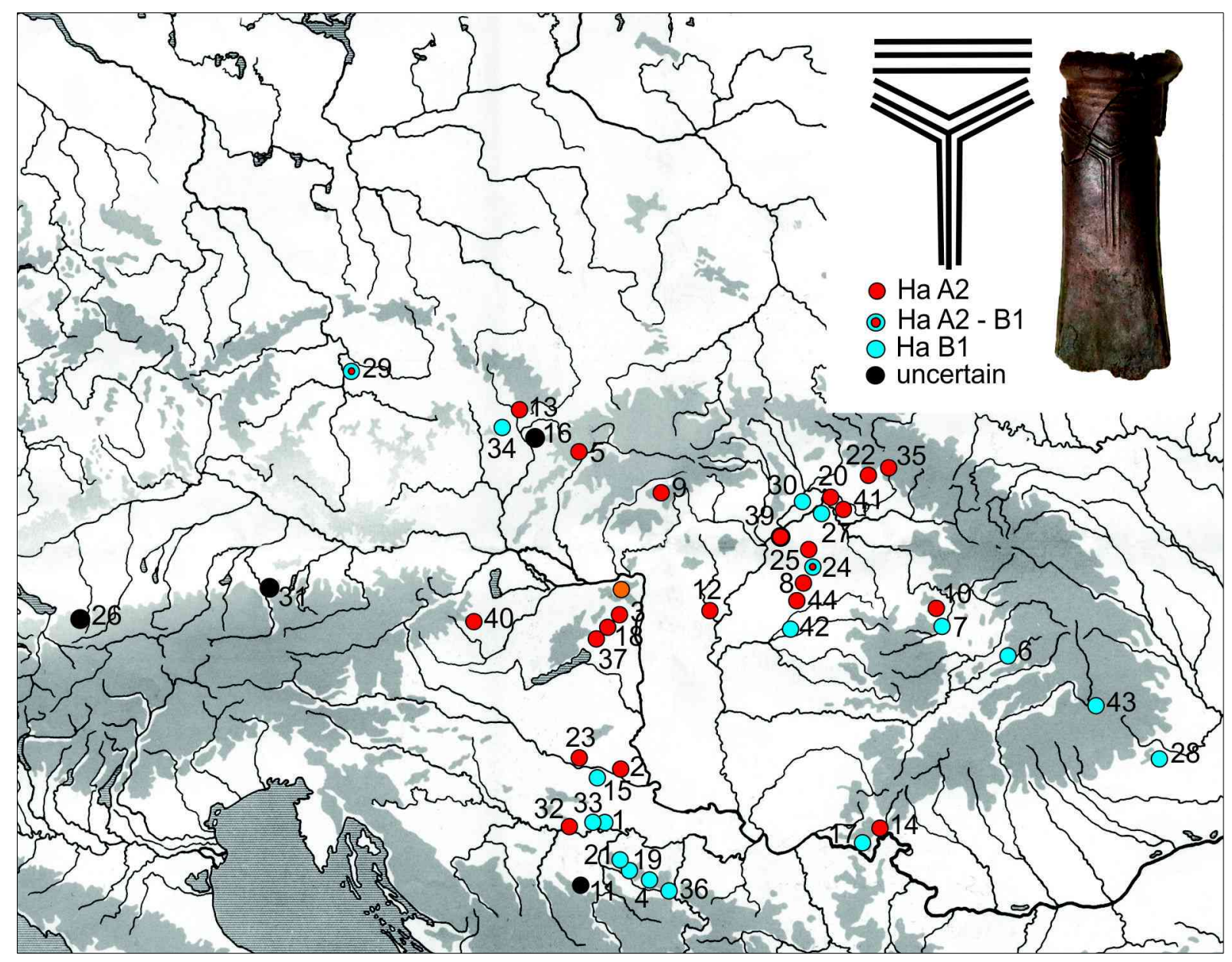

Fig. 11. The distribution of the No. 4 and 15. socketed axes (List 3).

No. 4 and No. 15 based on their patterns ${ }^{31}$ are comparable to the Boroffka - Ridiche's 2.b.6.a3$1 / 3$ decoration group. ${ }^{32}$ These widespread examples primarily concentrate in the Upper Tisza region and Transdanubia. However, they appear in other territories of the Carpathian Basin as well, moreover their examples are known sporadically from the Western part of Central Europe (List 3, Fig. 11). Earlier studies determined them as the most representative objects of the Ha A2 stage while the current research propounds - and we share a similar opinion - that they were also exist in the Ha B1. ${ }^{33}$ The socketed axe No. 5 belongs to the similar formal group although its patterns are quite unique. Hence, only six parallels are known from the Carpathian Basin and they were primarily deposited in Ha A1-A2 depots but axes with identical decoration

30 BoroffKa - Ridiche 2005, 150, Liste 8B3, Abb. 8, C9; von Brunn 1968, 47, Abb. 3.30; GAvranović 2011, 134-135, 138-140; Kemenczei 1996, 76-77, 78; KobAL' 2000, 41; KöNig 2004, 92, 101; MAYer 1977, 192; Mozsolics 1985, 36; Novotná 1970b, 83-87; Ř́Hovsky 1992, 203-205; WANZEK 1989, 106-109.

31 Three horizontal ribs, one $\mathrm{V}$ rib, one Y rib, two broken ribs.

32 In my estimation, the ones from Brezovo Polje, Dridu, Varatic 2, Szombathely and Slovenia have different decoration hence cannot be classified into this group. BorofFKA - Ridiche 2005, 150, Liste 8B3, Abb. 8.C9; ENĂCHIUC 1995, 280, Abb 9.1-2; Ilon 2002, 154, Abb. 6.3; Šinkovec 1995, 62, Pl. 16.88; ŽEravicA 1993, 94, Taf. 35.473.

33 This different dating is probably the result of the uncertainty of the Ha A2 stage. 
appeared in the Ha B2 (List 4, Fig. 12). ${ }^{34}$ Regarding to their features No. 6 and No. 7 are similar to the aforementioned axes, however they are undecorated. We are only aware of eight, comparable examples from the territory of Hungary and Croatia between the Ha A1 and Ha B1 stages. ${ }^{35}$ The narrow, curved forms like the No. 8, No. 9 and No. 10 are also considered to be uncommon. Some identical axes were deposited between the Ha A1 and Ha B1 stages mostly in the adjacent regions of the Carpathian Basin (List. 5-6, Fig. 12).

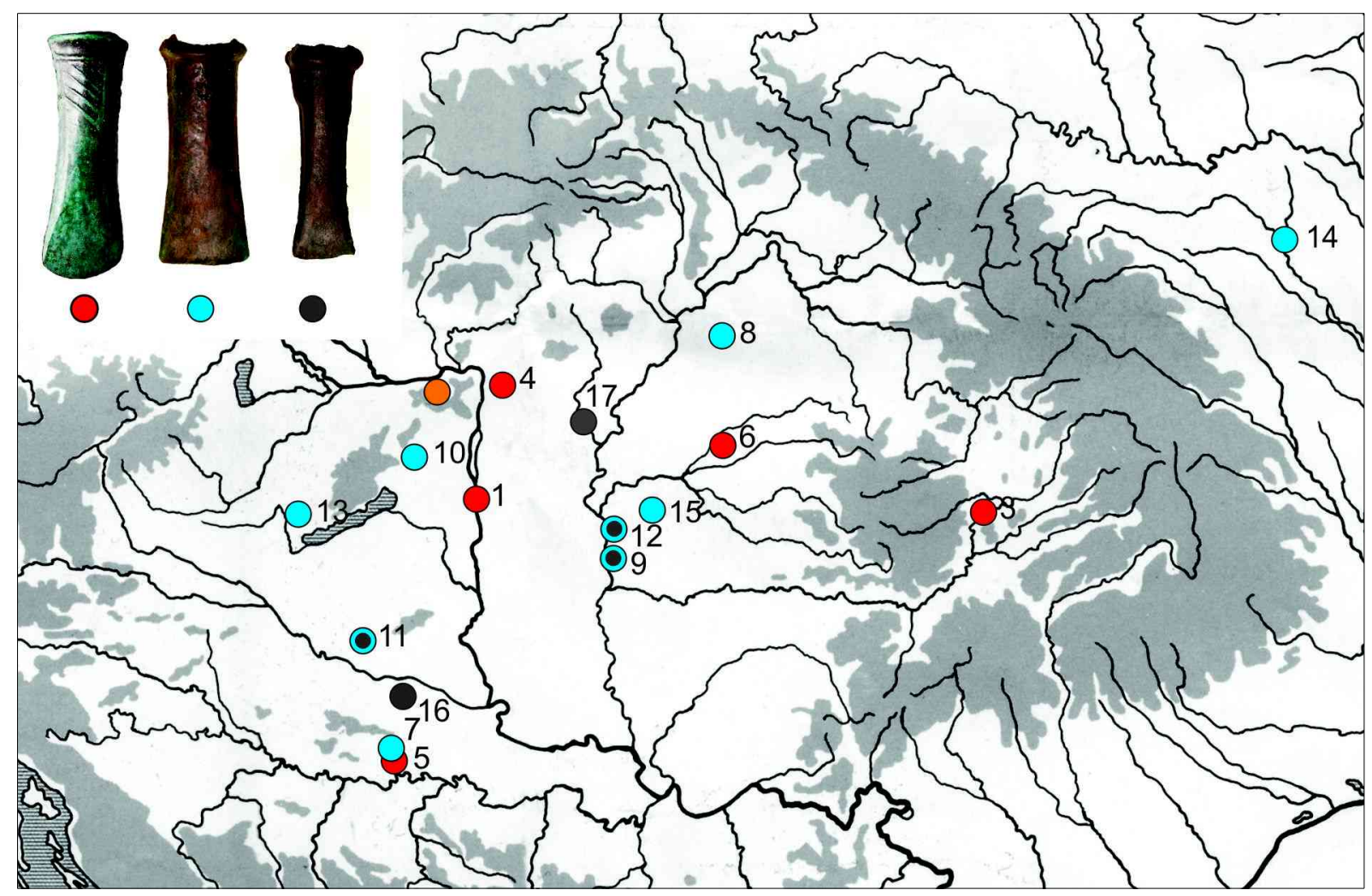

Fig. 12. The distribution of the parallels of No. 5, No. 6-7 and No. 8-10 socketed axes (List 4-6).

The macroscopic observations of the analyzed socketed axes (No. 4-11, 15-17) showed that they were mostly defective products with traces of minor (e. g. amorphous patterns, overflow) and major (e. g. dysfunctional socket, shifted body sides, porous breakage and external surfaces) casting faults. It is noteworthy that these specimens were also lack of post-production marks, for instance: fine polishing of the casting seams or hammering and sharpening of the edge. Therefore, their primary use as a multi-functional tool is highly unlikely. However, No. 12 and No. 13 are exceptions. Only slight asymmetry could be detected along their breakage surfaces but they can be interpreted as finished products in their every other aspects. The surfaces of these socketed axes are well-polished. In addition hammering and sharpening marks are also visible on their edges. In relation to the question of fragmentation only one axe (No. 6) remained intact. Three different types of explanations are possible for the current state of the rest of the axes: 1.) the fracture occurred due to the result of faulty casting process (e. g. No. 10-11); 2.) the fracture occurred due to deliberate destruction (e. g. No. 12-13); 3.) the fracture occurred due to post-depositional processes (e. g. No. 4, No. 8-9).

\footnotetext{
34 These patterns show slight differences, e. g. the one from Püspökhatvan has reverse motif. Kemenczei 1984, Taf. CXIII. 10; Mozsolics 1985, 178-179, Taf. 139.15. It should be noted that an identical example was sold at the London Coin Galleries under the name "Germany" (Fig. 12). http://www.londoncoin.com/antiquities/ancient-greece/1489/bronze-axe-head/ 35 Clausing 2003, Abb. 48.107; Vinski-Gasparini 1973, 212, Tab. 60.1-2.
} 


\section{3. Socketed chisel (Fig. 52.18)}

The Kesztölc depot contains a medium-sized socketed chisel with straight blade. Similar objects first appeared among the assemblages of the Aunjetitz culture (e. g. Vedrovice-Zábrdovice ${ }^{36}$ ). However, they have become characteristic during the Middle and Late Bronze Age when hundreds of them were buried into the ground as part of depots from the territory of France to the Noua-Sabatinovka sphere (e. g. the moulds from Malye Kopani) ${ }^{37}$ As many researchers pointed out, they also appear in prominent grave finds (e. g. Čaka, Bakonybél, Hövej, Lapus). ${ }^{38}$ The very first typology of these objects belongs to J. Hampel who evaluated them independently but also together with the group of socketed axes. ${ }^{39}$ Later, S. Foltiny differentiated the handled chisels (A) from the socketed ones (B) ${ }^{40}$ The following works mostly dealt with the fine typology of these objects. ${ }^{41}$ Nevertheless, different kinds of typological schemes were emerged from which the works of S. Hansen and G. Bălan should be emphasized. ${ }^{42} \mathrm{~S}$. Hansen used similar type of grouping as S. Foltiny, but his distinction based on the objects function-related edges (hollow or straight) and he also draws attention to the class of punching chisels. ${ }^{43}$ In his recent study, G. Bălan established a new typo-chronology which primarily focuses on the Romanian examples but also take into account the published examples from the whole territory of the Carpathian Basin and Western Europe. His classification, similarly to the aforementioned ones is practically based on the forms of the edges (Type I - straight blade, Type II - hollow blade) but he also distinguished fine formal and metrical groups (Variant Ia-c, Variant IIa-c) and individual forms (Type III-IV). ${ }^{44}$

In connection to the chisels function, they can be interpreted - similarly to the socketed axes - as multi-functional objects. According to the concepts of the research, they are suitable for wood-, leather- or bone-working, but some of them can be served as metallurgical tools and used with hammer or mallet. ${ }^{45}$ In relation with the previous one, these tools were associated with mould making or the destruction of metal artefacts. ${ }^{46}$ Damages which were possible caused by chisel can also be identified among the utensils of the Kesztölc depot (e. g. No. 2, No. 5). However, without experimentations, it is hard to prove completely that the chisel should be blamed for such damages. However, according to new archaeometric analyses these chisels with the aid of a hammer might be hard enough to crush or break other bronze utensils. ${ }^{47}$

36 HÁJEK 1959, 201, Obr. 1.4a-4b.

37 BĂLan 2009, 4; BočKarev - Leskov 1980, 56-57, Taf. 4.39-40; Dergačev 2002, 121-122; Hansen 1994, 150-151; KYTLICOVÁ 2007, 141; MAYER 1977, 222; Ř́́HOVSKÝ 1992, 270.

38 BĂLAn 2009, 4; Hampel 1886a, CXI. tábla; 1896, CLXXXVI. tábla; Hansen 1994, 151; Mozsolics 1985, 39; NovotnÁ 1970b, 70; SőTÉr 1892, 207-212, I. tábla 10.

39 Hampel 1896, 30-32, 42-43, X. tábla 9.

40 Foltiny 1955, 102-104.

41 Gavranović 2011, 136-138; Gedl 2004a, 155; Karavanić 2009, 86-88, Fig. 51; KytlicovÁ 2007, 141-143; Mayer 1977, 208-222; Mozsolics 1985, 38-39; 2000, 24; NovotnÁ 1970b, 67-70; SAlaš 2005a, 47-48; ŽEraviCA 1993, 110-113; PÁSZTHORY - MAYER 1998, 164-170.

42 BĂLAN 2009, 11-16, 29-31; HANSEN 1994, 150-154; WANZEK 1992, 262, 269-271.

43 HANSEN 1994, 150-154, Abb. 83-84.

44 BăLAN 2009, 11-16, 29-31. Within his scheme the chisel from Kesztölc falls close to the group of Ia-Ib.

45 Ferenczy 1976, 257, 61. kép; Hansen 1994, 150; Kytlicová 2007, 144; Mayer 1977, 221-222; Novotná 1970b, 71; PAnčíková 2008, 152; PÁszthory - Mayer 1998, 166; Speciale - Zanini 2010, 420; ŽeravicA 1993, 112. It is highly possible that socketed chisels with hollow edge can be served as wood-working tools because the modern woodworking chisels still have similar edge. CoBlenz 1989, 21; Ferenczy 1976, 254-259, 60a-b ábra; ŽERAVICA 1993, 112. Some may argue that the greater ones are suitable for causing great injuries therefore they can be sorted among the group of weapons. HANSEN 1994, 151; NovOTNÁ 1970b, 71.

46 Kytlicová 2007, 145; NovÁk - VÁczi 2010, 89-99; PANČíkovÁ 2008, 152; Rezi 2011, 316; SzABÓ $1993,199$.

47 Coblenz 1989, 21-22; MAYer 1977, 221; Müller 2011, 214-217, 5. ábra 22, 7. ábra 32; NeUnINGEN 1976, 441-442. 


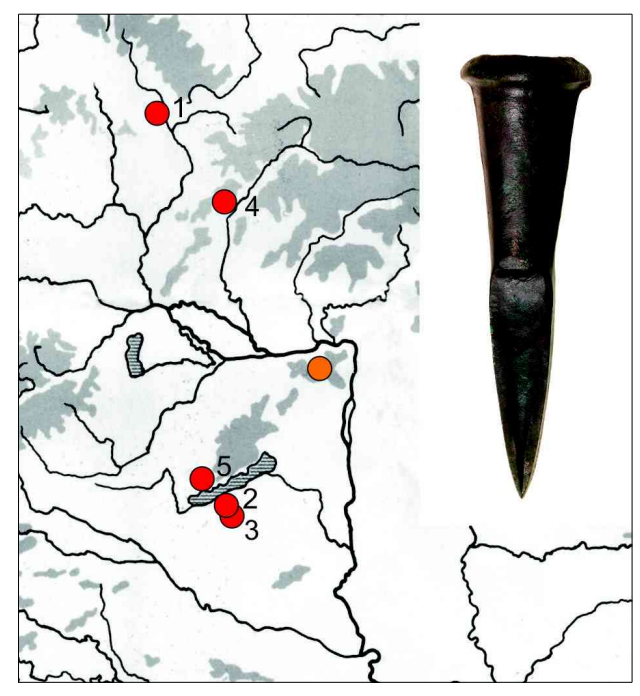

Fig. 13. The distribution of the parallels of the socketed chisel (List 7).

The chisel from Kesztölc is a typical Carpathian form. Identical objects with straight edge were unearthed from France to the Black Sea. Although, based on its fine features ${ }^{48}$ five examples from the Carpathian Basin and the territory of the present day Czech Republic can be determined comparable: Dubany, Lengyeltóti 2, Lengyeltóti 4, Trenčianske Bohuslavice, VárvölgyNagyláz-hegy (List. 7, Fig. 13). Most of these were dated to the Ha A1-A2 stage, only the one from Dubany has a later dating (Ha B1). From technological point of view, the chisel of the Kesztölc depot can be described as finished product with high quality. Its surfaces are well-polished and hammering traces are also visible on its edge. ${ }^{49}$

\section{4. Fragments offlange-handled sickles (Fig. 52.19-2O)}

The Kesztölc depot contains two unclassifiable flange-handled sickle fragments. These types of utensils were mostly interpreted as agricultural tools for harvesting grain crops or different type of fodder to feed the livestock. However, some may argue that the sickles were exchange of value, fertility symbols or in broken form such as the ones from Kesztölc they could serve as raw material. ${ }^{50}$ The main forms of these artefacts have been divided already at the end of the 19th and the beginning of the 20th century. ${ }^{51} \mathrm{H}$. Schmidt's four types division was the base of the later typologies. ${ }^{52}$ However, the first, detailed analysis of the flange-handled sickles was carried out by W. Angeli and H. Neuninger who divided their groups (A-E) based on the rib decorations along the handle. ${ }^{53}$ Recently, B. Wanzek analyzed 351 examples with statistical methods. He followed the steps of W. Angeli and H. Neuninger, nonetheless his scheme operated with large quantities of type and subtypes and primarily based on the patterns of the main types and their different combinations. ${ }^{54}$

Due to their atypical forms, the classification of the sickle fragments from Kesztölc is not possible without uncertainties. They could be parts of many different types of flange-hilted sickles from the Br D to the Ha B stage. However, the fragment No. 20 can be associated with Wanzek's A1 main group - which contains more than 181 examples - although, due to

48 1.) length: 10 or $12 \mathrm{~cm}$; 2.) conical base; 3.) thickened rim; 4.) proportional size of the blade and socket.

49 BĂLAN 2009, 10. Similar chisels are known from the following depots: Brandgraben, Borsodgeszt-Kerekhegy, CelldömölkSághegy 3, Černotín, České Zlatníky, Ciugud, Drslavice 2, Grünbach, Gyöngyössolymos 1, Peterd, Poljanci, Haidach. Aldea - Ciugudean 1995, 220, Fig. 3.4; Distelberger 1986, Taf. 1.6; Kemenczei 1984, 145, 326, Taf. CXVIb.6; KytliCovÁ 2007, 257, Taf. 2B.2; MAYer 1977, 220, Taf. 88.1302,1303; Mozsolics 1985, 122-123, 171-175, Taf. 14.2, Taf. 61.1-2; 2000, 38-39, Taf. 19.4; SAlaš 2005a, 332-342, 417-418; 2005b, Tab. 335.3, Tab. 148.45; Vinski-GASPARINI 1973, 218, Tab. 49.2.8; Windholz-KonRad 2008, Abb. 53.

50 Beranová 1993, 104-106, 108, Abb. 3; Clausing 2005, 91; Fumánek - Novotná 2006, 70-73; Hagl 2008, 73-75; Harding 2000, 124, 364-365; Hellebrandt 1989, 110, 12. kép; Mozsolics 1984, 52, Taf. 5.12; Primas 1986, 1, 15-20, 37-41, 43; Ŕ́́HOVSKÝ 1989, 6; SOMMERFELd 1994, 4, 269-270.

51 HAMPEL 1896, 52-58.

52 Bezzenberger 1910, 179-180; von Brunn 1968, 149; Foltiny 1955, 92-92; Furmánek - Novotná 2006; Gavranović 2011, 150-152; Gedl 1995; Hänsel 1968, 52; Kobal’ 2000; 44-47; Mozsolics 1985, 42-46; Petrescu-Dîmboviţa 1978, 1-3, 8-77; Primas 1986, 2-3, Abb. 1-2; Ř́novskÝ 1989, 3; SchmidT 1904, 416-450; VAsić 1994.

53 Angeli - Neuninger 1964, 80.

54 ANGELI - NeUNinger 1964; WANZEK 2002, 1. 
its fragmentary state detailed grouping is not possible. ${ }^{55}$ In relation with the macroscopic analyses, the breakage of No. 19 should be underlined which might be caused by deliberate bending. Comparable fragmentation was described earlier by B. Rezi within the framework of his progressive study on Romanian depots. ${ }^{56}$ However similar phenomenon is well-known from the whole region, including Transdanubia as well (e. g. Badacsonytomaj, ${ }^{57}$ Regöly $3^{58}$ ).

\section{5. Passementerie Fibulae (Fig. 53.21-22a-b)}

In the current analysis, we only would like to give a short presentation of the two passementerie fibulae from the depot and some newly appeared artefacts because they have been already evaluated within our recent study (Fig. 14-15). ${ }^{59}$ The research of the passementerie fibulae have been started at the end 19th and beginning of the 20th century. ${ }^{60} \mathrm{~A}$ classical work belongs to J. Filip who divided their main three groups: A, B, C. ${ }^{61}$ In the 1950s, J. Paulík presented new results and divided group A into A1, A2 and A3. ${ }^{62}$ Five years later, P. Patay postulated new data on these fibulae moreover he also distinguished further sub-types: A3a, A3b, A3c. ${ }^{63}$ In 1983, T. Bader summarized and updated the typology of the passementerie fibulae. He named the group A as "Rimavská Sobota type" and divided four types among the group C: Uzsavölgy, Sadská, Suseni, Sviloš. ${ }^{64}$ Based on his work, the following studies mostly presented new finds from the whole territory of the Carpathian Basin and Central Europe. ${ }^{65}$ To conclude, the passementerie fibulae classifiable into 4 main groups and can be divided into different sub-types: Group A (Type A1, Type A2/A2a and A2b, Type A3/A3b and A3c), Group B, Group C (Type Uzsavölgy, Type Sadksá, Type Suseni, Type Sviloš). ${ }^{66}$

As regards to their size and their manufacturing techniques, the groups of passementerie fibulae are diverse. These composite jewelries practically unite the wire, casting and basic metal sheet techniques. ${ }^{67}$ The so-called passementerie style or in other words the wire spirals fastened by traps can be found among high quality objects such as the golden jewelries, passementerie necklaces etc. ${ }^{68}$ Most of the passementerie fibulae are from depots, only small percent of them are from burials (e.g. Budapest-Békásmegyer grave 138, Celldömölk-Sághegy, Heršpice, Jasenica, Krásna Ves, Kotešová, Partizánské, Sadská, Senta). In the previous case the fibulae are too fragmented to classify, and the few anthropological remains of the burials provide diverse picture about the sex of the wearers (e. g. Budapest-Békásmegyer, grave 138 - male, Sadská, grave 13 - female). ${ }^{69}$

55 WANZEK 2002, 10, Abb. 4A1.

56 REZI 2011, 311, Fig. 2.

57 Mozsolics 1985, Taf. 235.6.

58 Mozsolics 1985, Taf. 29.8.

59 TARBAy 2012. The catalogue of our earlier study does not include the passamenterie fibula from the grave 4/1911 from Velika Gorica which is similar to the fibulae from Pobrežje and the one from Fridolfing. Karavanić 2009, 58, Pl. 63.3. The Gemer/Sajógömör find was also not appeared in that list. HAMPEL 1886b, V. tábla 23.

60 Åberg 1935, 55; Childe 1929, 342, 374, Pl. VII; HAmpel 1896, 135-137; MÁRTon 1911, 341-346; Miske 1910, 66-67, II. tábla 7; UndSET 1880, 54-57, Abb. 2, Taf. 12.6; Pulszky 1897, 163.

61 Filip 1936-1937, 120; Filip 1969, 1072-1073.

62 Paulí́ 1959, 328-362.

63 Patay 1964, 7-21.

64 BADER 1983, 41-45.

65 Dergačev 2002, 44; Gedl 2004b, 79-80; Kašuba 2008, 214-217; Kemenczei 1984; Kobal' 2000, 68-69; Kytlicová 2007, 38, 292-293, 306; Mozsolics 1985, 68-70; NovotnÁ 1970a, 57-60; 2001, 36-51; Ř́́HOvsKÝ 1993, 56-62; TeRžAN 2000, 37-38; VASIĆ 1999, 22-27;

66 BAder 1983, 41-56; Novotná 2001, 38-39; Filip 1936-1937, 120; 1969, 1072-1073; PATAY 1964, 15-17; TARbay 2012, 7. kép.

67 EőRY 2009, 4. kép 1-2.

68 Karavanić 2010, 89-90; Kemenczei 1999, 73, 78-79, Abb. 41-41a, Abb. 46; Mozsolics 1950, 29-39; 1985, 61; Novotná 1984, 48-52, Taf. 52.338-340, 60-62, Taf. 60.360-361; Šimić 2008, Abb. 8-8a.

69 DudÁs 1885, 349; Filip 1939, 27-28, Obr. 14; Kalicz-Schreiber 2010, 90, 272, Abb. 196, Taf. 60.18-19.22-23; Kőszegi 1988, 130, 47. tábla; Paulík 1959, 331, 334, 336, 357-358, Abb. 6-7; Mozsolics 1985, 69; Novotná 2001, 41, 50, Taf. 14.90. 

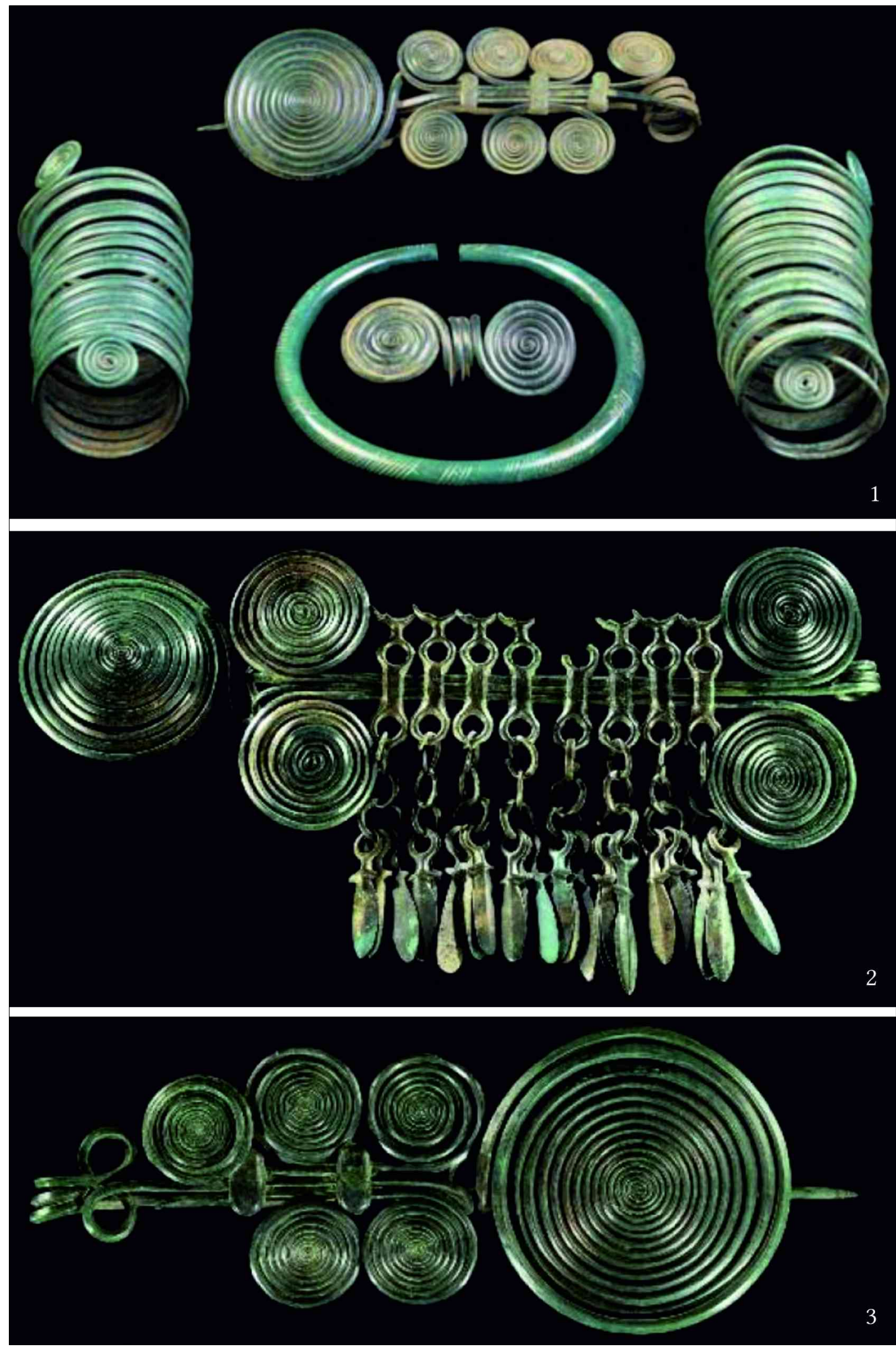

Fig. 14. Passementerie fibulae from auction houses. GoRnY\&Mosch 2011, $54-55$ (above);http://www.christies.com/lotfinder/lot/a-large-central-european-copper-alloy-bronze-2 034 933-details.aspx?intObjectID=2 034933 (2012.1.26, below). 

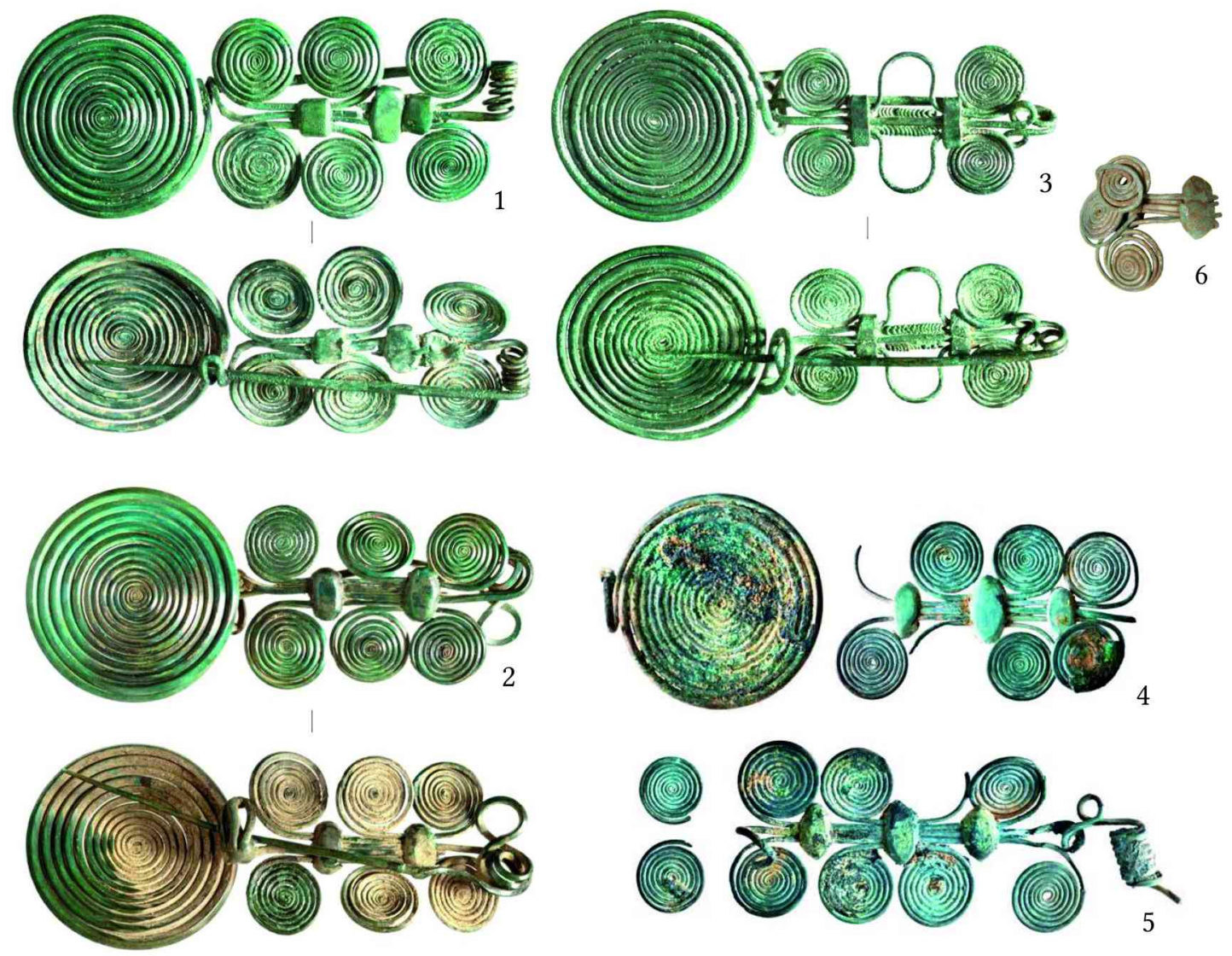

Fig. 15. Passementerie fibulae from the auction of Hermann Historica and the vakond blog:

1. Unknown (length: $2.02 \mathrm{~cm}$ ): http://www.hermann-historica.de/auktion/hhm67.pl?db=kat67_a.txt\&f= ZAEHLER\&c=286\&t=temartic_A_GB\&co=5 (2014.11.05).

2. Unknown (length: $19.5 \mathrm{~cm}$ ): http://www.hermann-historica.de/auktion/hhm67.pl?db=kat67_a.txt\&f= ZAEHLER\&c=284\&t=temartic_A_GB\&co=1 (2014.11.05).

3. Unknown (length: $21.8 \mathrm{~cm}$ ) http://www.hermann-historica.de/auktion/hhm67.pl? $\mathrm{f}=\mathrm{NR} \_L O T \& \mathrm{c}=2286 \& \mathrm{t}=$ temartic_A_GB\&db=kat67_a.txt (2014.11.05).

4-5. Unknown (lenght: $2-13.2 \mathrm{~cm}$ ): http://www.hermann-historica.de/auktion/hhm67.pl? $\mathrm{db}=$ kat67_a.txt\&f=ZAEHLER\&c=287\&t=temartic_A_GB\&co=6.

6. Unknown (Hungary?): http://vakond.hu/lexikon_fibula.htm (2013.04.06).

Thereupon, interpreting these objects as part of woman accessory is questionable, similar apply to the double fibulae wearing custom. ${ }^{70}$ It is also hard to determine the group of individuals who possess these jewelries. However, the elaborate and from technological point of view complex examples - such as the Group B and C - could be worn by the elite.

The passementerie fibulae are practically "international" objects, they equally appeared at the territory of the Unfield and Lausitz sphere, but examples are known from the Eastern and adjacent regions of the Carpathian Basin which were habited by the Gáva and Noua culture. ${ }^{71}$ Within this widespread group the fibula No. 21 from Kesztölc can be assigned to Type A3a. Its parallels dominate in Transdanubia, but similar finds can be found in the Upper Tisza region (Kenderes 2), Slovakia and in the North Hungarian Mountains: Érsekvadkert, 
Szécsény, Kammený Most, Rimavská Sobota, Trenčín. But comparable finds appears in Croatia (e.g. Brodski Varoš), Romania (e.g. Corneşti, Sânpetru German) and even in the territory of Poland (e.g. Pawłowice Namysłowskie, Swierczów). This subtype can be dated between the Ha A1 and Ha B1 stages (List 8, Fig. 15). ${ }^{72}$ The No. 22 can be grouped among the Uzsavölgy Type fibulae (Group C) which with one exception (e.g. Kuzmin, Serbia) dominate in Transdanubia (Badacsonytomaj-Köbölkút, Kurd, Lesenceistvánd-Uzsavölgy). ${ }^{73}$ Based on the fragments of Kurd, it can be hypothesized that this type had already appeared in the Ha A1 and not just in the Ha A2 (List. 9, Fig. 16). ${ }^{74}$

Both fibulae are in fragmentary state, rendering the identification of use-wear almost impossible. Only the No. 21 is suitable for drawing further conclusions. Its lead-spiral and some of its side-spirals are broken. On the case of the missing pin, traces of bending can be well-observed on the spring. However, this could be caused by post-depositional damage.

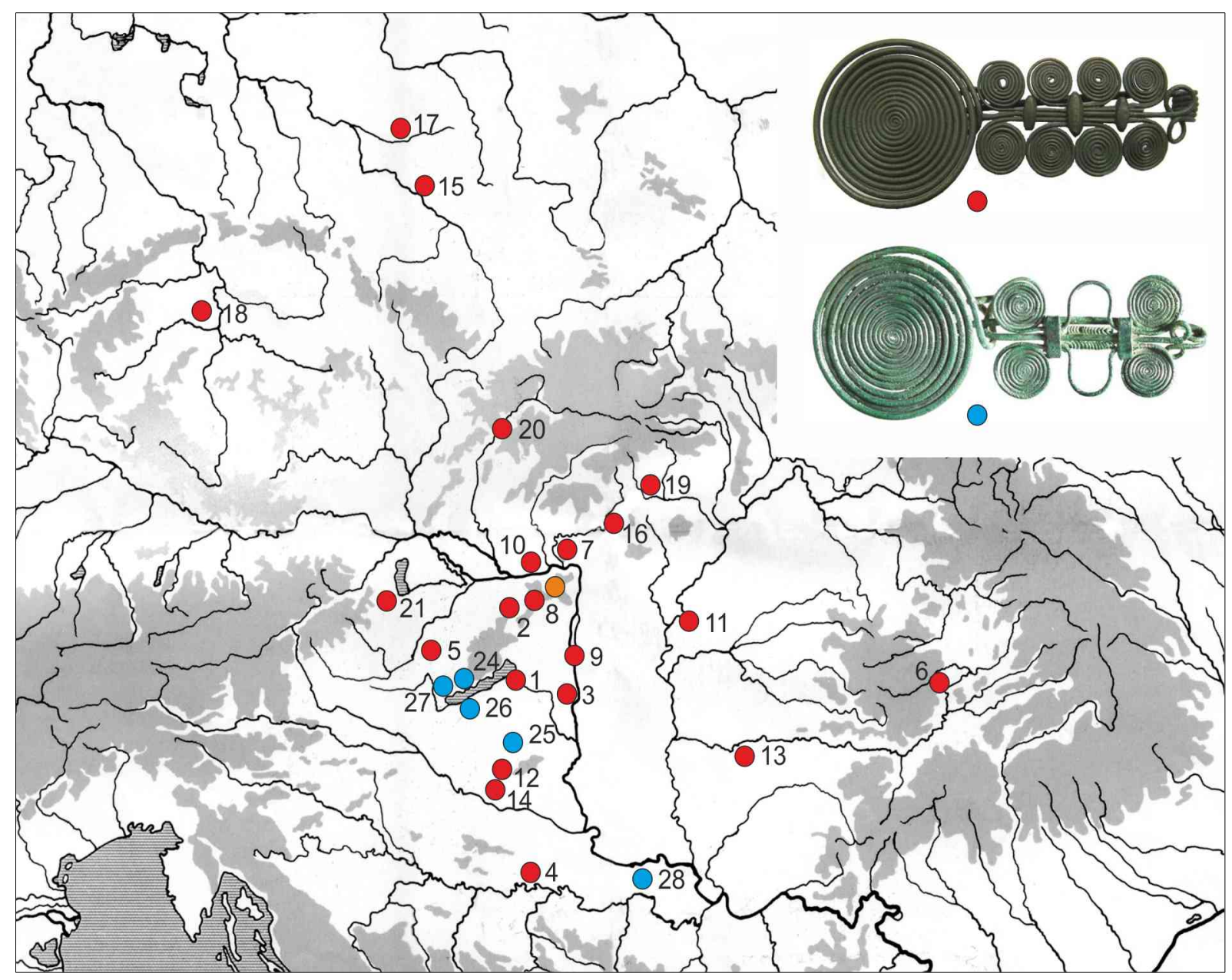

Fig. 16. The distribution of A3a- and Uzsavölgy-Type passementerie fibulaes (List 8).

72 TARbay 2010, 8. kép.

73 Tarbay 2010, 120-121; VAsić 1999, 24, Taf. 4.49.

74 TARbay 2010, 121, 8. kép. Recently, an intact example from an unknown location was sold at the Hermann Historica auction which was shortly presented on the Ásónyomon blog. http://www.hermann-historica.de/auktion/hhm67.pl? $\mathrm{db}=$ kat67_a.txt\&f=ZAEHLER\&c=285\&t=temartic_A_GB\&co=18 (2014.09.29). http://www.asonyomon.hu/egy-talanyoskeso-bronzkori-fibula/ (2014.09.29). 


\section{6. Belt (Fig. 54.23, Fig. 55.23.1-23.2, Fig. 56.23.3-23.4)}

The sheet belt of the Kesztölc depot belongs to a special costume group of the Bronze Age which was first classified at the turn of 20th century. ${ }^{75}$ Prominent is the monograph of I. KilianDirlmeier which she established the typo-chronology of the Central European belts and hooks. ${ }^{76}$ Later, her results were supplemented by many important studies which allow us to achieve a complex view of the belt wearing in the Late Bronze Age Carpathian Basin. ${ }^{77}$ The earliest sheet belts appeared at the end of the Middle Bronze Age and they had been being used with different intensity until the Late Iron Age. It is notable, that these objects were only a small parts of the whole belt custom which might have existed in the Late Bronze Age Carpathian Basin and in its adjacent regions. Many individual forms ${ }^{78}$, elaborate belt-plates ${ }^{79}$ and even an import ${ }^{80}$ are known from this period and territory. However, it is more likely that the organic ones were the dominant types. Their examples are well-preserved in Western and Northern Europe, furthermore they are known form the representations of anthropomorphic clay figures from Eastern Central Europe as well (e. g. Kličevac). ${ }^{81}$ The different types of belt hooks are also supported the existence of organic belts. ${ }^{82}$ In the Late Bronze Age (Ha A -Ha B) Carpathian Basin, these were mostly Western European types (e. g. Kelheim, Unterhaching, Wilten) ${ }^{83}$ or individual forms ${ }^{84}$ In this issue, the attachments - like buttons, pendants or even mountings - are also significant. ${ }^{85}$

The predecessors of the Late Bronze Age sheet belts, or the so called Sieding-Szeged-Type belts are mainly known from Middle Bronze Age (Br B - MD II) burials. ${ }^{86}$ Most of them were buried in female graves (e. g. Sieding barrow 1 or the cemetery of Tápé) however they can be associated with masculine symbols (e. g. the Keszthely-Boiu-Type sword representation on decoration of the belt from Chotín) or were buried in male graves (e. g. Csabrendek). ${ }^{87}$ The Late Bronze Age examples were divided into five groups by I. Kilian-Dirlmeier: 1.) RiegseeType; 2.) belts with punched decoration; 3.) belts with embossed decoration; 4.) raw materials/semi-finished products; 5.) individual forms (e. g. Nočaj-Salaš). ${ }^{88}$ The Riegsee-Type belts are decorated with chains of spirals, dots and triangles and they are characteristic in the

75 Hampel 1896, 139-141; Foltiny 1955, 38-39.

76 Kilian-Dirlmeier 1975.

77 HANSEN 1994, 236-252; HÄNSEl 1968, 109-112; KARAvAnić 2007, 59-67; 2009, 123-130; MozsOlics 1985, 58-60; SALAŠ 1997, 42-44; Schumacher-Matthäus 1985, 110-114; ReZi 2013.

78 E. g. Bonin, Komjatná, ”Hungary”, Nočaj-Salaš, Skalsko, Záluži. GedL 2009, 47, Taf. 54B4; HAMPEL 1886a, CXXI. tábla 4-6, XliV. tábla 4-5; Kilian-Dirlmeier 1975, 112, Taf. 46.549; Kytlicová 2007, 303-304, 316, Taf. 107.20, Taf. 164.1.

79 E. g. Jobaháza, Kapelna, Konjuša, Úvalno, Velikaja Began’ or Zmeevka. Kilian-DirLmeIER 1975, 92, Taf. 30/31.379, Taf. 34.392; Kobal' 2000, 98, Taf. 93.56; Vinski-Gasparini 1973, 214, Taf. 111.1-4; Mozsolics 2000, 50, Taf. 41.6.

80 SzABó 2009, 349-350, 10. ábra.

81 Bergerbrandt 2007, 54-55, Fig. 39; Glob 1977, Fig. 21; KNöPke 2009, 142-146, Abb. 57; Schumacher-Matthäus 1985, 111, Taf. 52 .

82 BónA 1959, 51, 4. kép; HÁjek 1959, 285-300; Kilian-Dirlmeier 1975, 11-89.

83 Kilian-Dirlmeier 1975, 64, 67-69; Kobal' 2000, Taf. 54B.4.

84 E. g. Békásmegyer, Bogdan Vodă, Gyermely, Jászkarajenő, Spišská Belá. KALICz-SchreIBER 2010, 269-270, Typentaf. 13.11.12; Motzoi-Chicideanu - Iuga 1995, Abb. 7.19; Mozsolics 1985, Taf. 240.1, Taf. 251.20; Novotná 1970a, Taf. XXXIX.

85 An organic belt which composed of small buttons was excavated in the grave 376 of the Tápé cemetery. ScHumAcHERMAtthäus 1985, 111; Trogmayer 1975, 150, Taf. 33.376.

86 The currently known finding places of the Sieding-Szeged-Type belts: Aiud, Band, Chotín, Csabrendek, DebrecenFancsika, Gilching, Hungary, Kiskundorozsma, Kriva Reka, Pitten, Püspökhatvan, Sármellék, Sieding grave 1, Szeged, Szentes, Tápé grave 124, Tetétlen, Velebit grave 94. Hansen 1994, 237, 240, 606, Abb. 149; HäNSEL 1968, 111-112; KiliANDirlmeier 1975, 100-103, 136, Taf. 60; LANGENEcker 1994, 269-272; Willvonseder 1935, 223 ; $1937,136$.

87 Furmánek et Al. 1999, 176, Taf. 31a-b; Trogmayer 1975, 150; Willvonseder 1937, 136, 297, Taf. 31.7-9.

88 Kilian-Dirlmeier 1975, 99-155. The group of sheets belts with embossed decoration is problematic. Some of them can be clearly interpreted as belt (e. g. Budinščina) but others based on their terminals and dimensions are closer to the group of diadems. Karavanić 2007, 59-67; Kilian-Dirlmeier 1975, 113-114, Taf. 46.460; Mozsolics $1985,59$. 
cemeteries of the South Bavarian and Tyrolean region. However, examples are known from the Czech Republic, Austria and Hungary. Their easternmost appearance is located at the Northern Carpathian Basin (e. g. Levoča, Sipš). While the Western European ones are well-dated to the Br D stage, the Southern examples are mainly parts of Ha A depots (e. g. Lengyeltóti 2) (List 10.1, Fig. 17). ${ }^{89}$ The punched belts with different kinds of decorations like spirals, discs or even wheel and sun motifs, are characteristic for the Ha A stage (Fig. 18). ${ }^{90}$ This type appeared in Transylvania, Transcarpathia, Hungary, Croatia and Serbia but identical examples are known from the territory of Poland, Czech Republic and Germany (List 10.2, Fig. 19). ${ }^{91}$

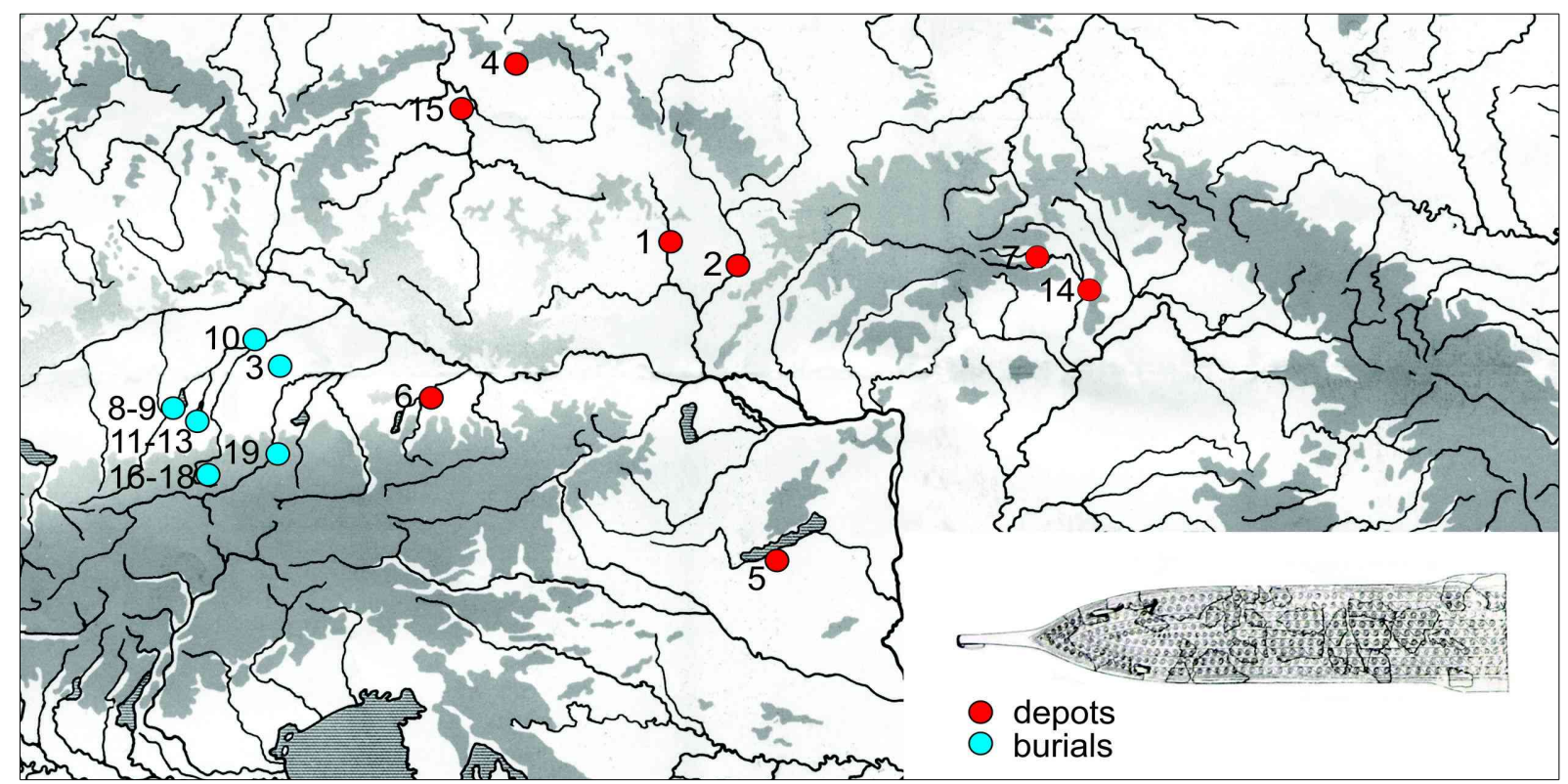

Fig. 17. The distribution of Riegsee-Type belts (MüLLER-KARPE 1959b, Taf. 180J.7; List 10.1).

The undecorated ones - like the belt from Kesztölc - are closely related to the group of punched belts, no wonder that their spatial distribution also correlates with them. Apart from the two Czech examples (Měrovice and Polesoviče) most of them concentrate in SzabolcsSzatmár-Bereg county, but they also appeared in Transylvania. Two further examples are known from Transcarpathia (e. g. Makar'evo, Užgorod) and from the territory of Croatia and Serbia (List 10.3, Fig. 20). The belt from Kesztölc plays an important role in the question of distribution, because it is the first undecorated one from Transdanubia. The dating of its group also correlates with the decorated ones. They had appeared first in the Br D, but most of them were deposited in the Ha A1, however later examples are also known (e.g. Merrovice - Ha A2, Mérk - Ha B1). ${ }^{92}$ Different opinions have formulated on the exact function of this group. W. A. von Brunn suspected that they were covered with decorated textile sheath. Contrast to him, I. Kilian-Dirlmeier, S. Hansen and M. Salaš interpreted them as semi-finished products or raw materials. ${ }^{93}$

89 Hansen 1994, 470-471, Abb. 150; Karavanić 2007, 62-65; Kilian-Dirlmeier 1975, 6-7, 104-107, Taf. 43.426, Taf. 60; Kytlicová 2007, 276, 314; Mozsolics 1985, 143; ŠAlas 2005a, 138; WANZEK 1992, 249. The belt fragment from Levoča was classified improperly because the object in question clearly belongs to the group of Riegsee-Type belts based on its characteristic decoration. FURMÁNEK ET AL. 1999, 176, Taf. 29b.

90 von Brunn 1968, 41; Karavanić 2007, 65; Kilian-Dirlmeier 1975, 111-112; Pare 1987, 44-45, Fig. 3. In the case of the ones from the territory of the Czech Republic an earlier dating can be suspected (Br D2). ŠALAs 2005a, 138.

91 Hansen 1994, Abb. 151; Kilian-Dirlmeier 1975, 107-111.

92 Kemenczei 1996, 84; Kilian-Dirlmeier 1975, 115-116; Salaš 2005, 138-139.

93 von Brunn 1968, 41; Hansen 1994, 240-241; Kilian-Dirlmeier 1975, 115-116; SAlaš 1997, 41, Taf. 25.620. 

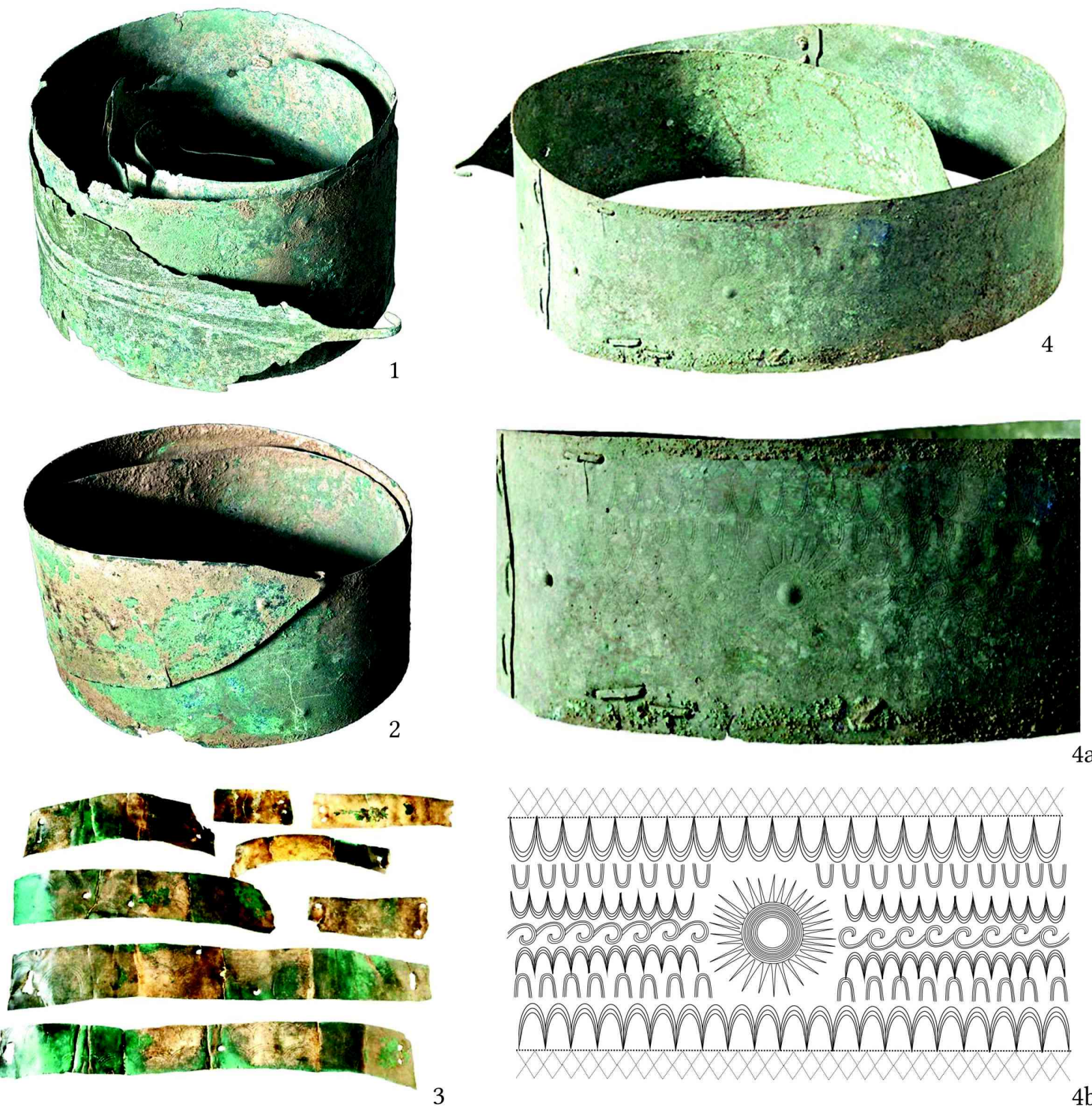

$4 b$

Fig. 18. Carpathian belts from Western European auctions.

1. Hermann Historica: http://www.myseum.de/index.php?option=com_adsmanager\&page=show_ad\&ad $\mathrm{id}=1710 \&$ catid (2014.11.05).

2. Hermann Historica: http://www.myseum.de/index.php?option=com_adsmanager\&page=show_ad\&adid $=1709 \&$ catid=29\&Itemid=60\&expand=0\&prevpage=show_category\&text_search=\&prevuserid=103\&prevcatid= 29\&prevorder $=0 \&$ prevlimit $=10 \&$ prevlimitstart $=30$ (2014.11.05).

3. http://www.hermann-historica.de/auktion/hhm50.pl?f=NR\&c=26 781\&t=temartic_1_GB\&db=A-50.txt (2014.11.05).

4. The belt from Hermann Historica which is stylistically close to the ones from Felsődobsza and Sântana. KILIANDirlmeier 1975, 108; Mozsolics 1973, 134-135, Taf. 47.33; GogÂltan - SAvA 2010, Fig. 14; http://www.myseum.de/index.php?option=com_adsmanager\&page=show_ad\&adid=947\&catid=29\&Itemid=60\&expand=0\&prevpage=show_category\&text_search=\&prevuserid=103\&prevcatid=29\&prevorder $=0 \&$ prevlimit $=10 \&$ prevlimit start=50 (2011.3.23). 


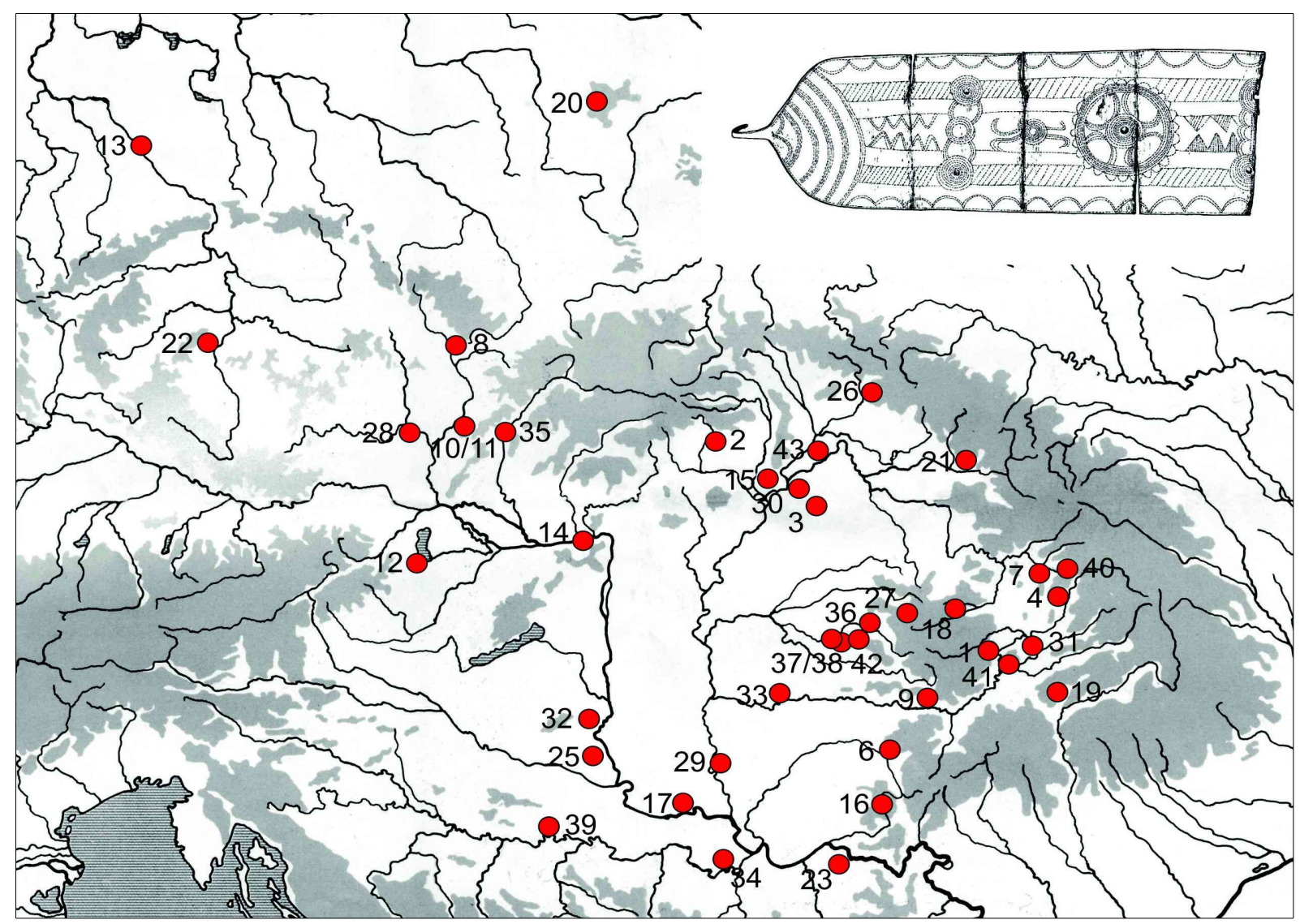

Fig. 19. The distribution of the belts with punched decoration (Mozsolics 1985, Taf. 207.1; List 10.2).

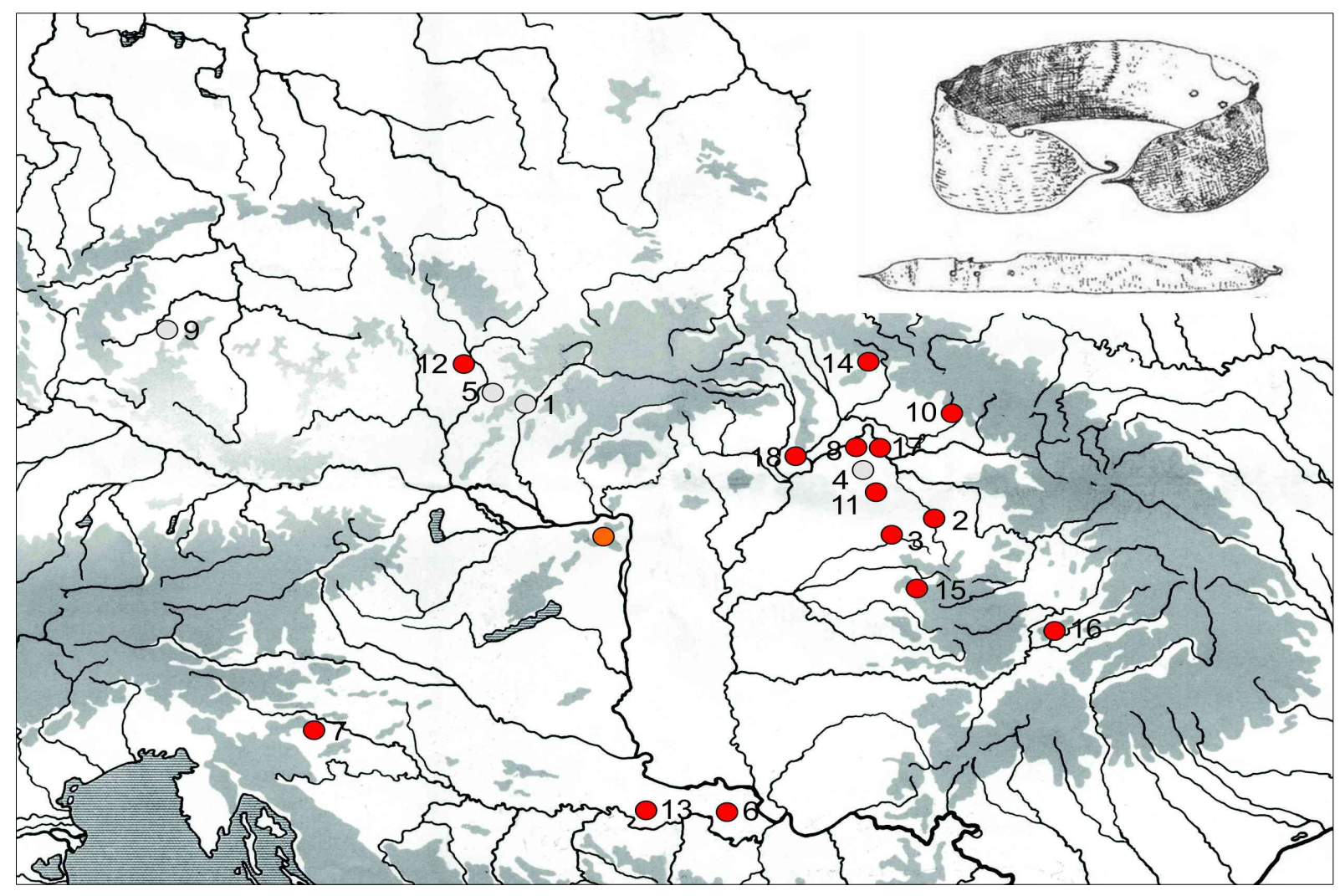

Fig. 20. The distribution of undecorated belts (JósA - Kemenczei 1963-1964, Taf. XXXIII.8a; List. 10.3). 
The opinion of S. Karavanic should be underlined who drew attention to the fact that the smaller undecorated belt fragments could be parts of decorated ones. ${ }^{94}$ In my estimation, most of the undecorated belts can be interpreted as wearable, finished products. Firstly, many examples (e. g. Jarak, Szabolcsbáka, Tállya) have hooks and row of holes for closing which allow the comfortable buckling similarly to the decorated ones. Secondly, clear traces of repairs are visible on the belt from Kesztölc which supports of its wearing (Fig. 55.23.1). However, the opinion of I. Kilian-Dirlmeier cannot be disproved completely because the belts without hooks and row of holes or traces of repair (e. g. Banka) evidently were not in use. ${ }^{95}$

III. 7. Torques (Fig. 57.24-26)

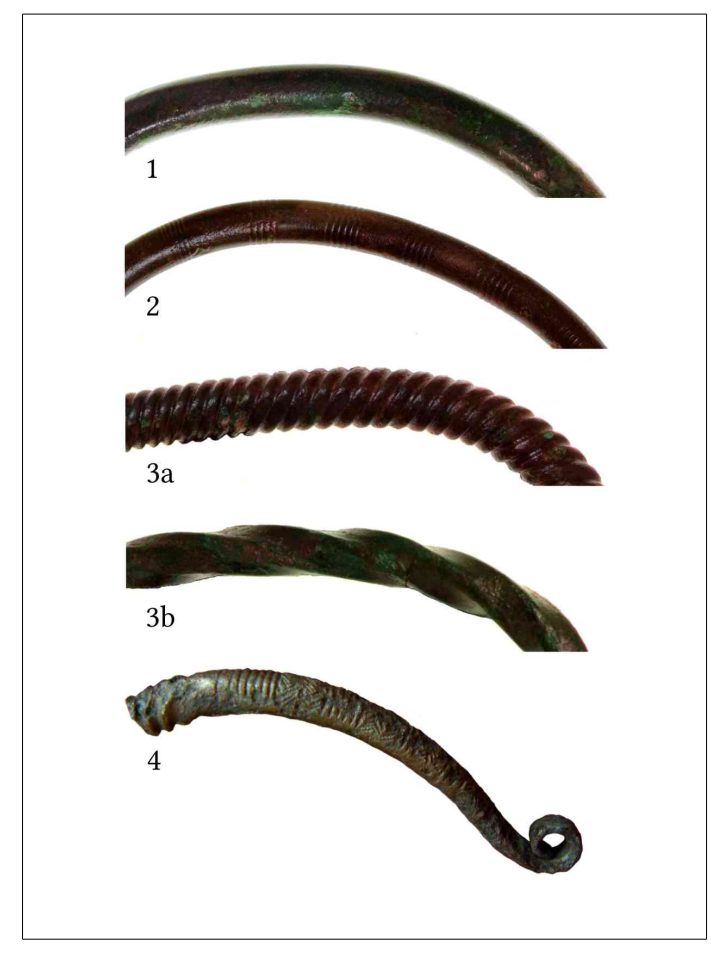

Fig. 21. The decoration types of the torques with rolled terminals (or something like that): 1 . undecorated, 2. decorated with lost-wax casted motifs, 3a. pseudo-torsion, 3b. torsion, 4. hybrid style.
Three fragments of torques with rolled-terminals were buried in the Kesztölc depot. It is notable that all of them were bent into circles similarly to the other finds from the Carpathian Basin. Their decorations are characteristic among this widespread jewelry group: torsion (No. 26), pseudo-torsion (No. $25)$ and line decoration which could have been created by lost-wax casting (No. 24). ${ }^{96}$ These artefacts were primarily categorized based on their formal (e. g. types of cross-sections and end-zone) and stylistic (e. g. torsion, pseudo-torsion, decorated, undecorated) features. ${ }^{97}$ The custom of wearing torques had been constantly evolved since the Copper Age. Its examples distributed from Germany to the Carpathian Basin and to the Northern part of the Balkan. ${ }^{98}$ It should be emphasized that the torques with rolled terminals still existed in the Early Iron Age. ${ }^{99}$ The artefact in question can be determined as jewelry, based on the anthropomorphic plastics of the Middle Bronze Age (e. g. Kliečevac, Dupljaja) and the Late Bronze Age female and male burials (e. g. Békásmegyer, Chotín grave 40, Kojuša, Szombathely-Zanat grave 31). ${ }^{100}$ Their role in the deposition practices is also significant because in some cases they were deposited in a great number (e. g. the region of Bonyhád, ${ }^{101}$ Dridu $^{102}$, Kanalski Vrh I ${ }^{103}$, Nadap, ${ }^{104}$ Románd ${ }^{105}$ ), moreover most of them were damaged by prehistoric manipulations similarly to the Kesztölc depots finds.

\footnotetext{
94 Karavanić 2007, 54, Abb. 1. For instance: the belt from Cubulcut. KözéPessy 1901, 365; Petrescu-Dîmboviţa 1978, 118, Taf. 92B.12.

95 Kilian-Dirlmeier 1975, 115-116, Taf. 52.480; Novotná 1970a, 88, Taf. XLIX.

96 BORN 1992, 290-294; SzABÓ 1996, 215.

97 Foltiny 1955, 21; Hampel 1896, 125-126; Kobal’ 2000, 58; König 2004, 82, 112; Kytlicová 2007, 74; Mozsolics 1985, 60; NovotnÁ 1984, 2, 9-13, 28-32; VAsić 2010, 17-43.

98 Mozsolics 1985, 60; Novotná 1981, 121-122; 1984, 2, 9-13; VAsić 2010, 15-16, 22-43.

99 ECKers 1996, 54-55; Sprockhoff 1956a, 146-147; Sydow 1995, 3; WeLs-WeyrauCh 1978, 162.

100 Ilon 2011, 171, 33. ábra 3, 81. ábra 4; KALICZ-SchreIber 2010, 45-46, Taf. 27.13; NovotnÁ 1984, 35; VASIĆ 2010, 37, 41, 47-54. Similar figure were sold at the auction of Hermann Historica.

101 Mozsolics 1985, 102-104, Taf. 39.28-29.31.

102 EnĂCHIUC 1995, Abb. 3.1-3.7-8, Abb. 4.3-6, Abb. 4.6-10.

103 ČERČE - ŠINKOVEC 1995, 203, Pl. 97.10-12, Pl. 99.14-17.

104 MAкKay 2006, XXIV. tábla 213-214, XXV. tábla 210,212,215,241,247.

105 Mozsolics 2000, 70-73, Taf. 86.23-26.
} 


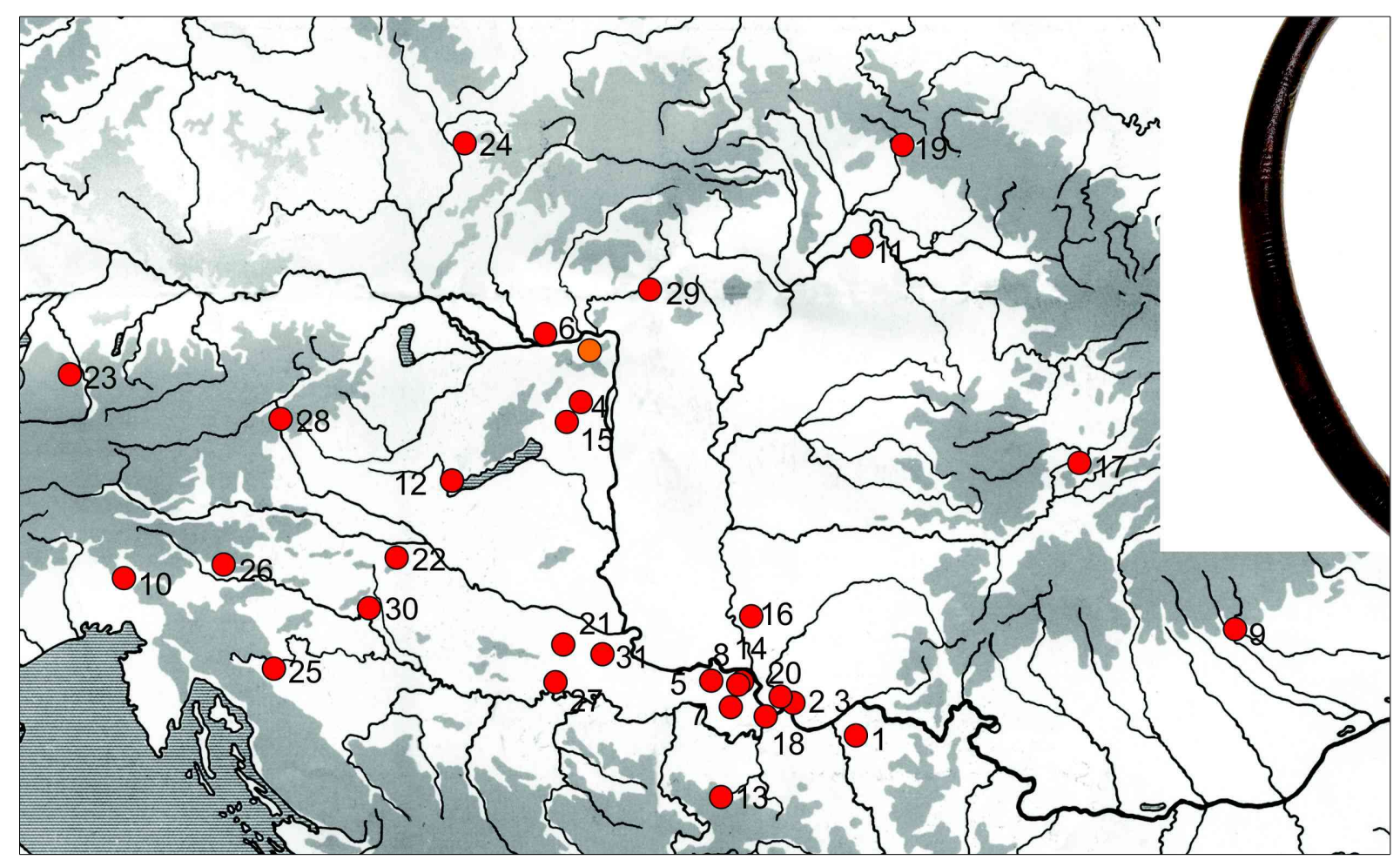

Fig. 22. The distribution of torques with lost-wax casted motifs (List 11.2.2).

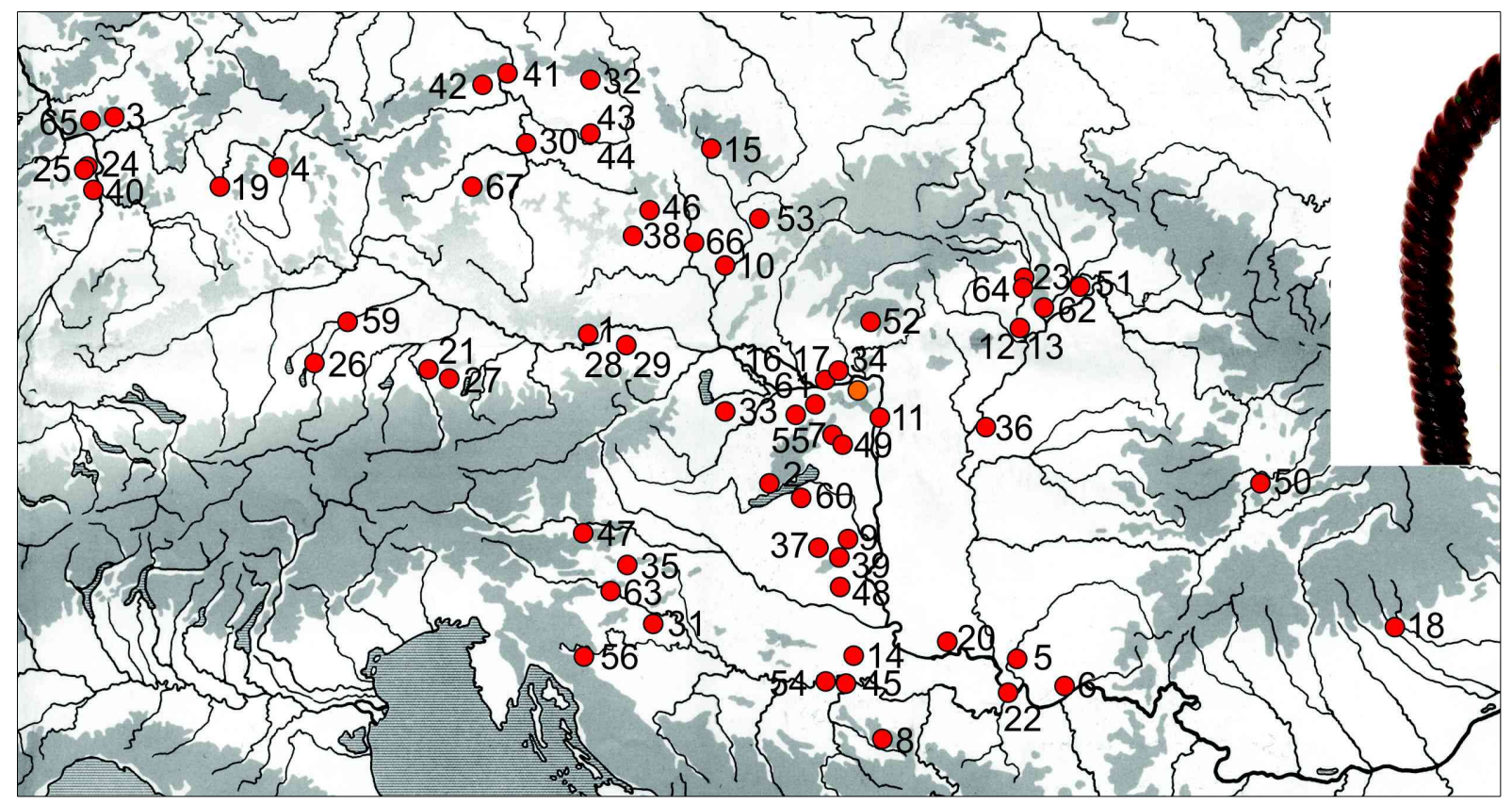

Fig. 23. The distribution of torques with pseudo-torsion (List. 11.3). 


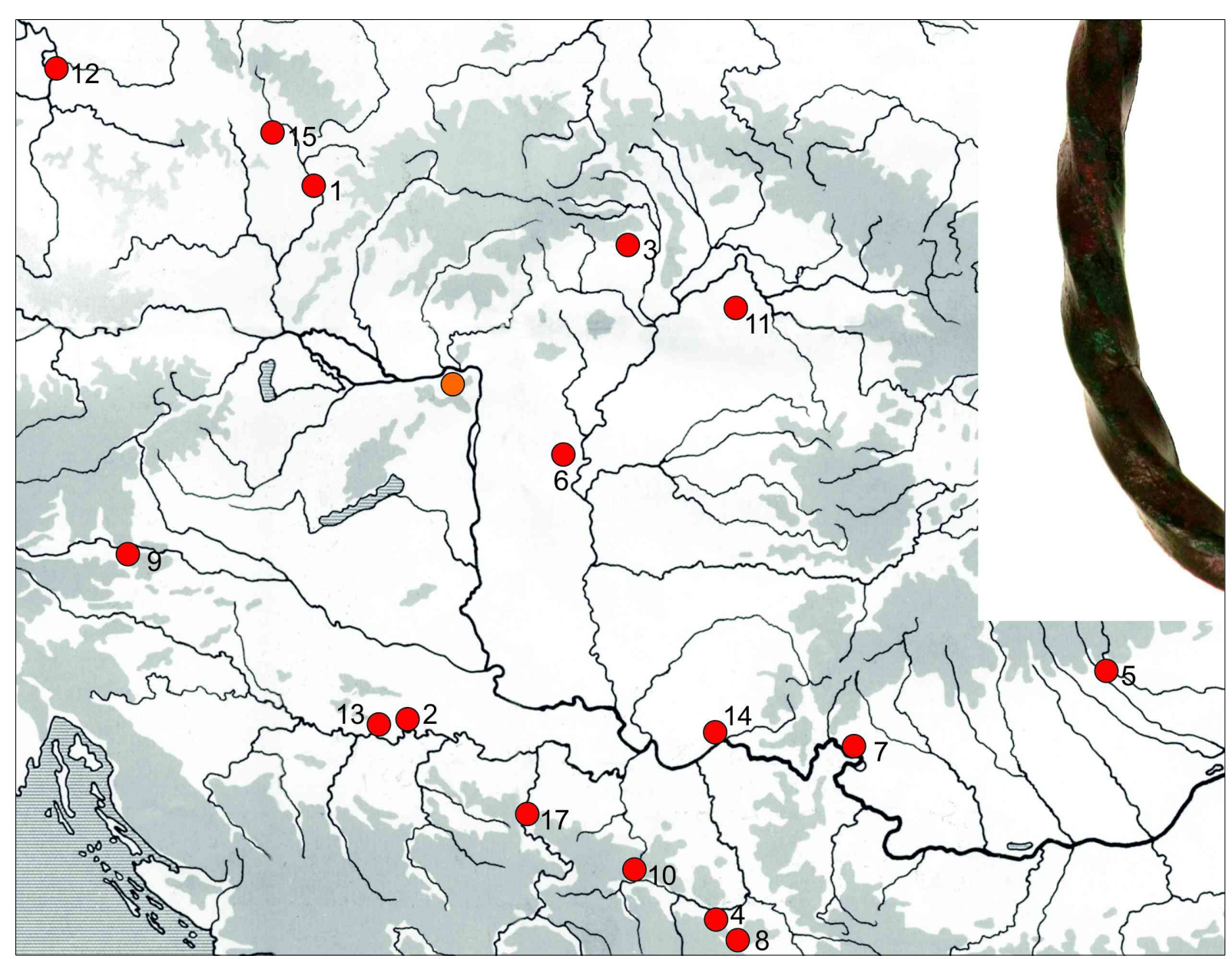

Fig. 24. The distribution of torques with torsion (List 11.4).

From typological point of view, the torques with pointed-terminals sortable into four style groups: 1.) undecorated; 2.) decorated with lost-wax casted lines; 3a.) dense-torsion (or pseudo-torsion); 3b.) loose-torsion; 4.) hybrid style (Fig. 21). ${ }^{106}$ The first group appeared in the Ha A1, but its examples are known in the Ha A2 (e. g. Přestavlky), Ha B1 (e. g. Monj) and even in the Ha 2/3 (e. g. Jobaháza) stages (List 11.1). The decoration of the second group mostly reaches the beginning of the end-zone but in some cases they cover it totally (e. $\mathrm{g}$. Nadap $^{107}$ ). These patterns composed of diagonal lines (e.g. Donji Petrovci ${ }^{108}$ ) or fishbone like and other geometric patterns. It is important to note that elaborate individual decorations (e. g. Biatorbágy-Herceghalom ${ }^{109}$ ) are also known from the Carpathian Basin. Their oldest example $\left(\right.$ Belgrad $\left.^{110}\right)$ can be dated to the $\mathrm{Br} \mathrm{D}$ although most of them belong to the Ha $\mathrm{A} 1$ or $\mathrm{Ha}$ A2 (e. g. Biatorbágy-Herceghalom) and Ha B1 (e. g. Dridu) stage. According to their decoration,

106 In the present study we classify the torques with rolled terminals. It should be underlined that we are aware of the limits of this current grouping: 1.) Due to the illicit trade and metal detector activities this artefact group suffered a great loss; 2.) The torques type in question closely related to group of bracelets with rolled terminals. Therefore dividing their fragments - based on the publication - can be inaccurate; 3.) The pseudo-torsion cannot be differentiated from the torsion based on the state of publications. For this reason we use the names of "dense-torsion" and "loosetorsion". To resolve these problems the whole group of torques should be republished but this work exceeds the goals of the present study. Mozsolics 1985, 60; V. SzABó 2013, 798-801, Fig. 3.3, Fig. 5.4; VAsıć 2010, 34.

107 MAKKaY 2006, Pl. XXV.241.

108 VAsić 2010,23 , Taf. 12.87.

109 Mozsolics 1985, 127-128, Taf. 238.1.

110 VAsić 1982, 268. 
larger examples from the Ha A1 (e. g. Budinščina ${ }^{111}$ ) and Ha A2 can also be linked to this group (List. 11.2, Fig. 22). The next group composed of torques with pseudo-torsion (3a) and torsion (3b). ${ }^{112}$ The 3a style can be observed mostly among the Ha A1 depots, but they appeared in the Ha B3 and even between the Ha C and Ha D (e. g. Vaskeresztes, Regöly 2). ${ }^{113}$ The section of these torques is mostly rounded which is characteristic for the Carpathian Basin but quadratic-sectioned ones are known from Bosnian and Croatian Ha B1 finds (List 11.3, Fig. 23). It is notable that during this period, the thickness of the torques was increased. The No. 26 of the Kesztölc depot presents the $3 \mathrm{~b}$ group which distribute in the same geographical area between the Ha A1 and Ha B1 stages as the aforementioned types (List 11.4, Fig. 24). For the last style group (4), the combination of torsion and geometric patterns is characteristic. Prominent examples are known from Keszohidegút and the territory of Slovakia (Gemer, ${ }^{114}$ Včelínce, ${ }^{115}$ Žírany ${ }^{116}$ ) but they appeared in Bosnia and Hercegovina (Drenov dô) as well. ${ }^{117}$ Similarly to the above, these torques deposited between the Ha A1 and Ha B1 stages (List 11.5). To conclude, the three torques from Kesztölc classifiable into the style group of 2, 3a, 3b. and can be dated between the Ha A - Ha B stages.

III. 8. Rings (Fig. 58.27 - Fig. 59.28-32, Fig. 60.33-38, Fig. 61.39-45, Fig. 62. 48-51, Fig. 63.5358, Fig. 64.59-67)

The depot contains of 41 rings which belong to four different types: 1.) circular-sectioned, opened ring with rounded-terminals; 2.) circular or slightly quadratic-sectioned opened rings with pointed terminals; 3.) opened ring with rhomboid-section and pointed terminals; 4.) closed ring with flattened, rhomboid-section. Comparable rings were known from the early beginnings of the research, which primary focused on its functional and typological aspects. In the 18th century, it has been suggested by F. Kiss that certain types of Bronze Age rings were functioned as measure of value during the process of prehistoric exchange but the wearable ones were served as bracelets or anklets. ${ }^{118}$ In the later studies, the rings were primarily interpreted as costume accessories. ${ }^{119}$ The typo-chronological research presented new results in the 1990s. ${ }^{120}$ Simultaneously, based on Babilonian, Egyptian and Mycenaean weight systems, the pre-monetar aspects of ring were under discussion. ${ }^{121} \mathrm{G}$. Kalla formulated dissent in connection with the pre-monetar interpretations. In his study, based on the definition of G. Dalton, he described the concept of primitive money and stated that local weight systems could have existed in the Bronze Age Europe. ${ }^{122}$ Prominent are the work of G. Szabó who differentiated three technological ring groups: 1 . cast bronze rings; 2 . rings ornamented with clusters of lines; 3 . hammered bronze rods bent into a circular shape. ${ }^{123}$

111 VinSKi-GASPARINI 1973, 212, Taf. 78.22.

112 VASIĆ 2010, 38-43.

113 Fekete 1995, 42, Abb. 3.1, Abb. 5.3-5; Kalicz-Schreiber 2010, 272; Mozsolics 1942, XV. tábla 1-4.7-10; Sydow 1995, 37; VASIĆ 2010, 42.

114 Novotná 1984, 32, Taf. 40.258.

115 Novotná 1984, 32, Taf. 40.260.

116 Novotná 1984, 32, Taf. 40.261.

117 KÖNIG 2004, 196-197, Taf. 56.11-12.

118 KIss 1859, 174-216.

119 HAMPEl 1896, 126-129; Miske 1907, 47; Szentmártoni Darnay 1899, 21.

120 Blajer 1984; Mozsolics 1985, 63-66; Petrescu-Dîmboviţa 1998; PÁszthory 1985; Richter 1970.

121 Einwanger 1989, 445, 449, 461-462; HAMPEL 1880, 29-32; Ilon 1992, 254-255; Kőszegi 1984, 280; 1988, 63, 73; MÁrtoN 1907, 64-65; Mozsolics 1963a, 76; SzABó 1996, 215. Noteworthy is the suggestion of B. Maráz, according to which, these rings could have been served also as raw material during the casting process MARÁz 1989, 14-15.

122 Dalton 1965, 44-45, 198-200; Kalla 2000, 83.

123 Oszvald - SzaBó 1996, 98-100; SzABó 1996, 214-216. 


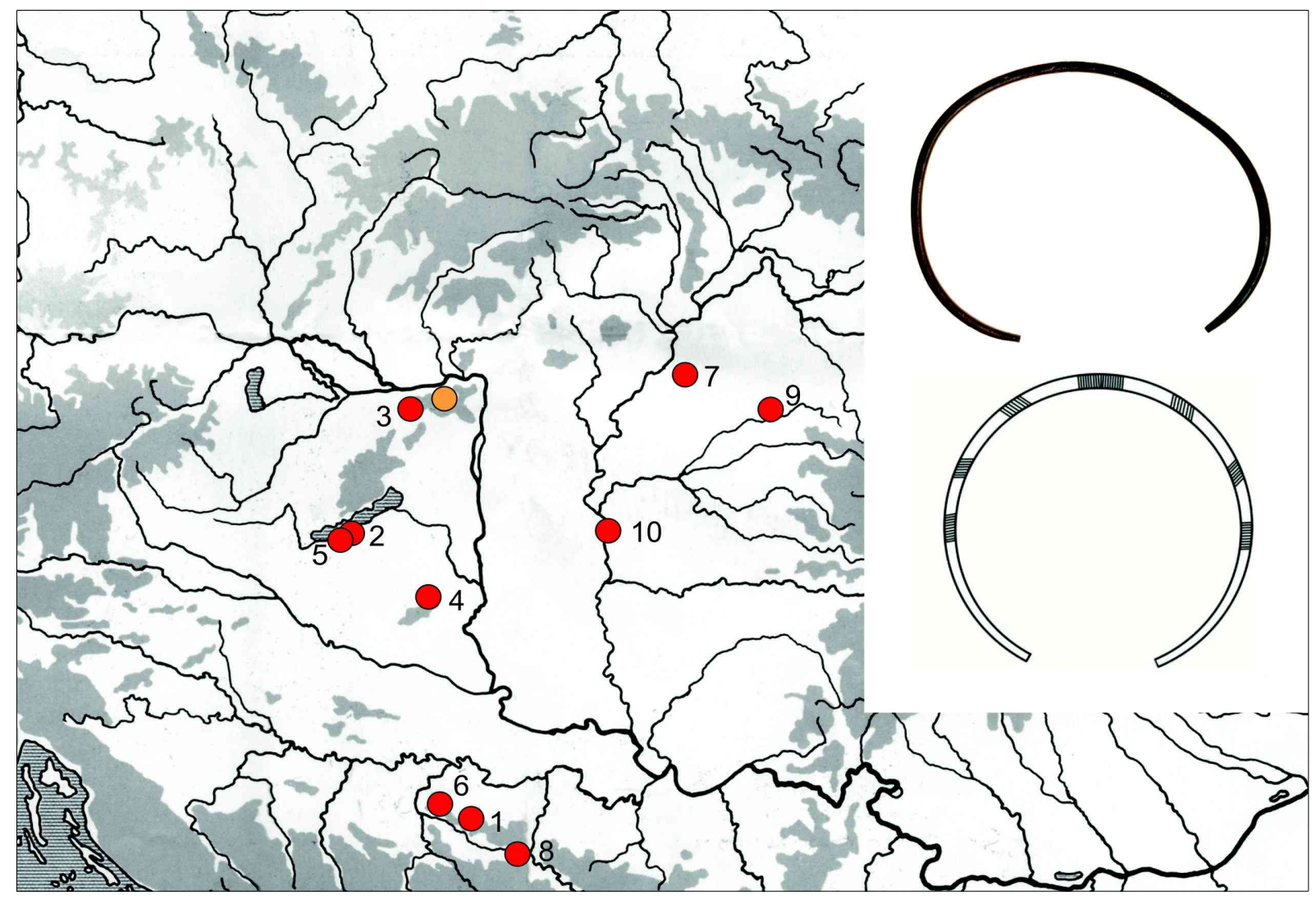

Fig. 25. The distribution of round-sectioned rings with line decoration (List. 12).

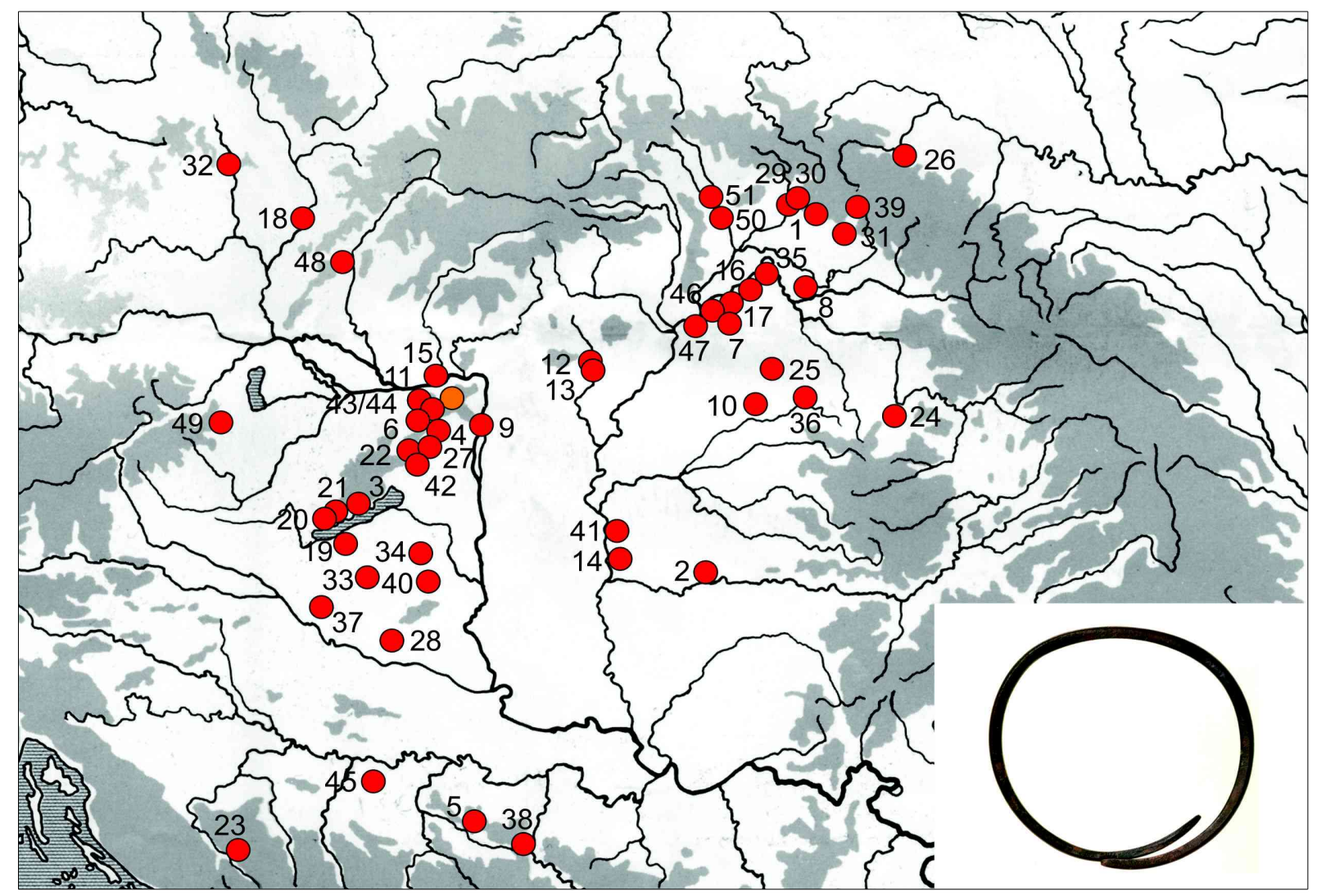

Fig. 26. The distribution of rings with pointed-terminals (List 13). 
The opened rings with rounded-terminals (No. 27) are characteristic in Transdanubia (e. g. Lengyeltóti 2, Fonyód) but similar finds are known from the territory of Bosnia and Hercegovina as well. ${ }^{124}$ Their first examples appeared in the Ha A, however they dominate among the Ha B1 depots. Both G. Szabó and H. Born suspected that the patterns of these of rings were made by lost-wax casting (List 12, Fig. 25). ${ }^{125}$

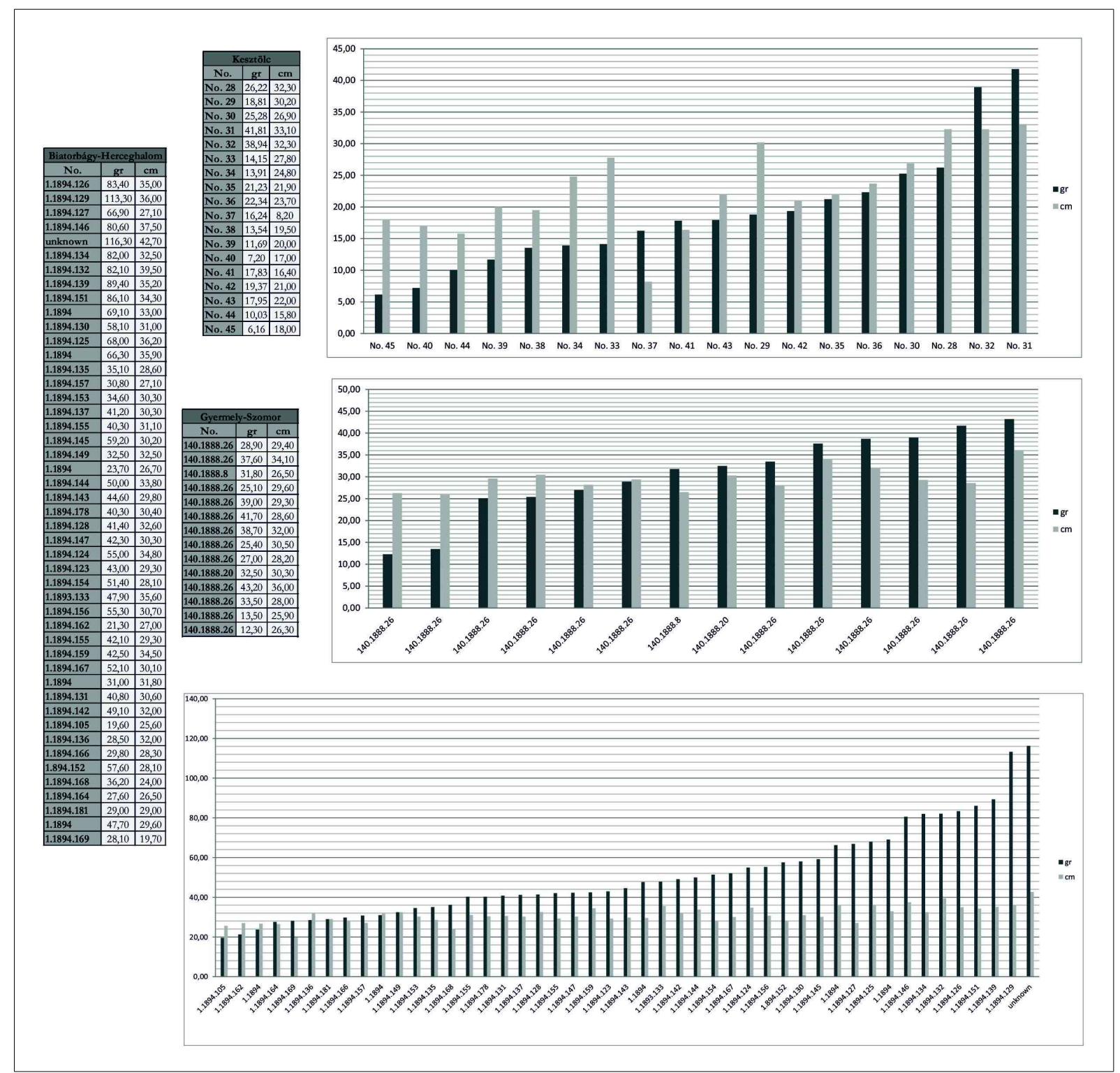

Fig. 27. Comparison between the outstreched length and weigth of the intact rings with pointed-terminals from the Biatorbágy-Herceghalom, Gyermely-Szomor and Kesztölc depot.

The 38 rings with pointed-terminals (No. 28-65) are typical forms of the Ha A1 - Ha A2/B1 depots in North-Eastern Hungary, Transcarpathia, Transylvania and Transdanubia. It should be noted that these rings are quite frequent among the so called Gyermely-type depots and they were often buried in groups of 10, 20 or even 40 (List 13, Fig. 26). ${ }^{126}$ In connection with 
their function these objects can be interpreted as jewelries. ${ }^{127}$ Within the framework of my MA thesis, following the method of G. Szabó, I had the opportunity to compare the metrical data (weight and outstretched length) of the intact rings with pointed terminals of the depots from Kesztölc (17 pieces), Gyermely-Szomor (14 pieces) and Biatorbágy-Herceghalom (49 pieces). As a result of this attempt, individual objects were unfolded without any standardization. Therefore, I believe that these results could also prove that the rings with pointed terminals were used as jewelry and their individual dimensions maybe correlated with the wearers physical endowments (Fig. 27). ${ }^{128}$

The third one (No. 66) which predecessors had first appeared in the Koszider horizon is characteristic to the Br D stage however its later examples are known from the Ha A as well. ${ }^{129}$ Due to its fragmentary state its original form is hard to reconstruct therefore the determination of its closest parallels is practically not possible. However comparable examples can be found in the territory of Hungary ${ }^{130}$, Slovakia ${ }^{131}$, Ukraine $^{132}$ and Romania. ${ }^{133}$

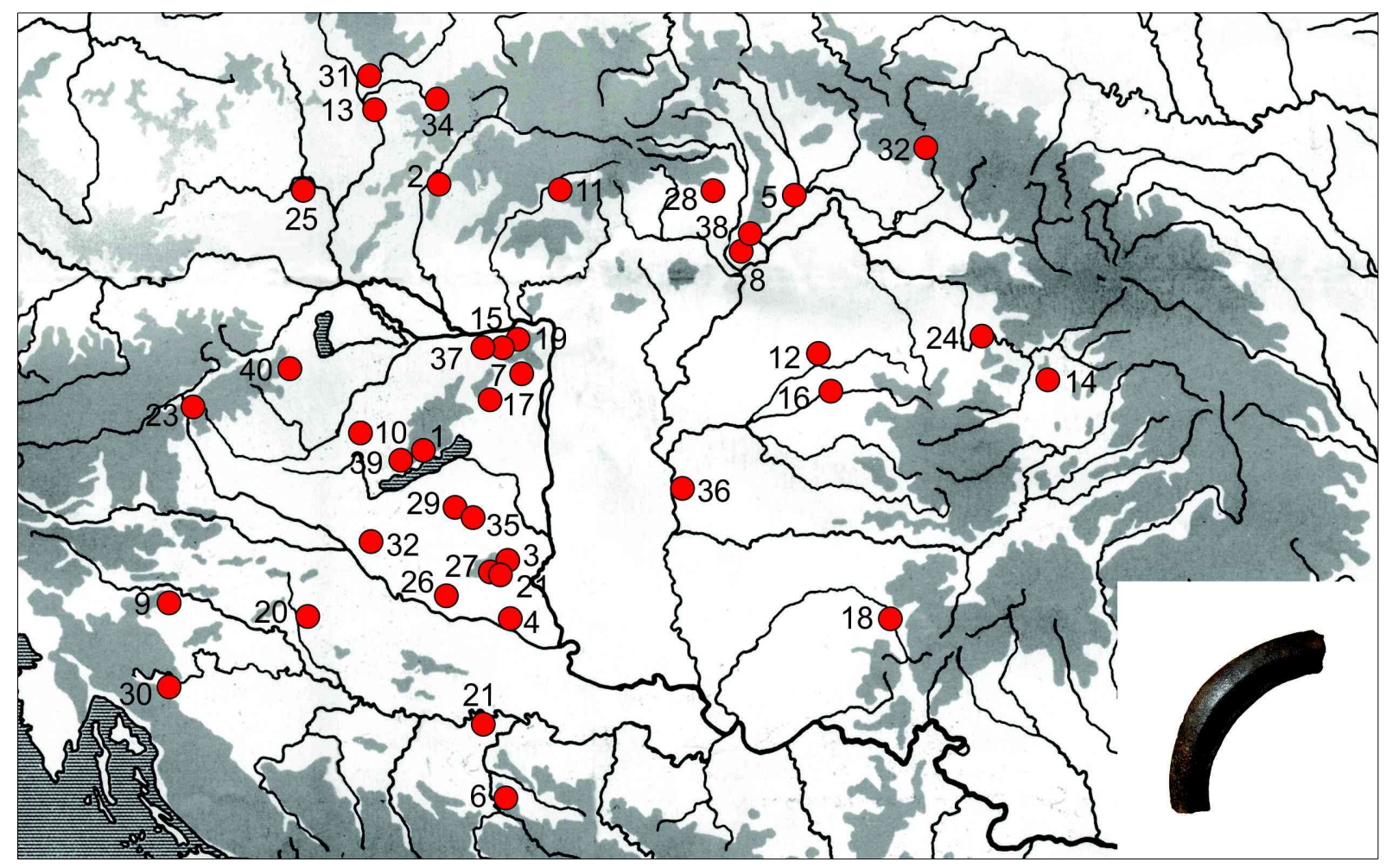

Fig. 28. The distribution of the rhomboid-sectiond rings (List 14).

The fourth type (No. 67) belongs to the group of closed rings with rhomboid cross section which are also characteristic in the Carpathian Basin between the Ha A1 and Ha A2 period. However, they appear in later depots (Ha B1/2) as well (List 14, Fig. 28). Their function is questionable, as A. Mozsolics pointed out that their dimensions and cross-sections are unsuitable

127 Mozsolics, 1985, 63-64; SzABó 1996, 216.

128 SzABÓ 1996; TARBAy 2013, 66. kép.

129 Mozsolics 1973, 60-61; 1985, 64.

130 e. g. Balsa, Jászkarajenő, Kisvarsány. Kemenczei 1984, 376, Taf. CLXVI. 20; Mozsolics 1973, 149-150, Taf. 54.6; 1985, Taf. 251.19.

131 e. g. Královce. Mozsolics 1973, 141, Taf. 68.3-4.

132 e. g. Nižnie Vorota, Veliki Lučki, Volovec, Suskovo 1. KoBAL’2000, 90, 95-96, 99-100, Taf. 12.11.13, Taf. 26B.2, Taf. 30.27, Taf. 73B.10-11.

133 Petrescu-Dîmboviţa 1998, 117-127. 
for comfortable wearing. In addition, composition analyses proved that some of them were made of white bronze (e. g. Máriakéménd) which could support their interpretation as ingots. ${ }^{134}$ The possibility cannot be excluded that some of them were parts of complex utensils. Similar rings can be found on the loops of situlae (e. g. Hosszúpályi) but they appear among the "chained objects" as well. ${ }^{135}$

From technological point of view, the rings with pointed-terminals should be underlined. Only small part of them are intact (No. 28-34, No. 36-44) the others are fragments or highly fragmentary (No. 35, No. 45-65). It is notable that most of them are bended (e. g. No. 29, No. 32, No. 33, No. 35) or were broken by bending (e. g. No. 45, No. 46, No. 48, No. 54, No. 61, No. 63). Similar phenomenon can be observed on the ring No. 27 as well. No. 66 is a failed casted object. Porosity is visible along its breakage surface and its sides are shifted due to the imprecise contact of the bivalve mould. Contrast to this No. 67 can be interpreted as high quality product without traces of any casting faults.

\section{9. Chained objects (Fig. 64.68)}

No. 68 belongs to the group of "chained objects": a special type of depositional phenomenon in Carpathian Basin during the Late Bronze Age. These chained objects classifiable into three groups: 1.) together casted closed rings, 2.) folded objects, 3.) objects folded on a closed ring or other type of artefact. The No. 68 can be categorized into the last group which is the most common in the analyzed area. These chained objects largely composed of rings, however, fragments of torques, pendants, buttons, fibulae, sheet objects and even razors can be parts of them. ${ }^{136}$ They had appeared first in the Br D stage, but identical ones are known from the $\mathrm{Ha} \mathrm{A} 1$ period. At the turn of the $\mathrm{Ha} \mathrm{A} 2$ and $\mathrm{Ha} \mathrm{B} 1$, their quantity decreased in the depots, nonetheless they became quite frequent among the Ha B1-Ha B3 depots (List 15, Fig. 29). This object was generally interpreted as a "prehistoric wallet" and named as "portemonee", "Pfalbaugeld" or "portemonnaies lacustres". According to this theory, they were basically a collection of valued raw material which could be easily transported and used during the process of prehistoric exchange. ${ }^{137}$ In my opinion, other interpretations are also possible. Chained rings are parts of handspirals (e. g. Hegyhátszentmárton) and other objects such as belts. ${ }^{138}$ Moreover, these could be also the results of destructive manipulations during the process of deposition. ${ }^{139}$ This can be supported by fact that they are primarily known from depots. Moreover, heat manipulation and special utensils are necessary to chained them.

\section{10. Metal sheet tubes (Fig. 65.69-76)}

The Kesztölc depot contains eight, decorated sheet tubes. Despite the fact that these objects are known from the 19th century their exact purpose is still under discussion. ${ }^{140}$ Comparable finds were interpreted as beads or part of a necklace, sabretache and even organic belts. ${ }^{141}$ According to W. Modrijan, the sheet tube from Wörschach could have been a part of horse tack or jewelry. ${ }^{142}$

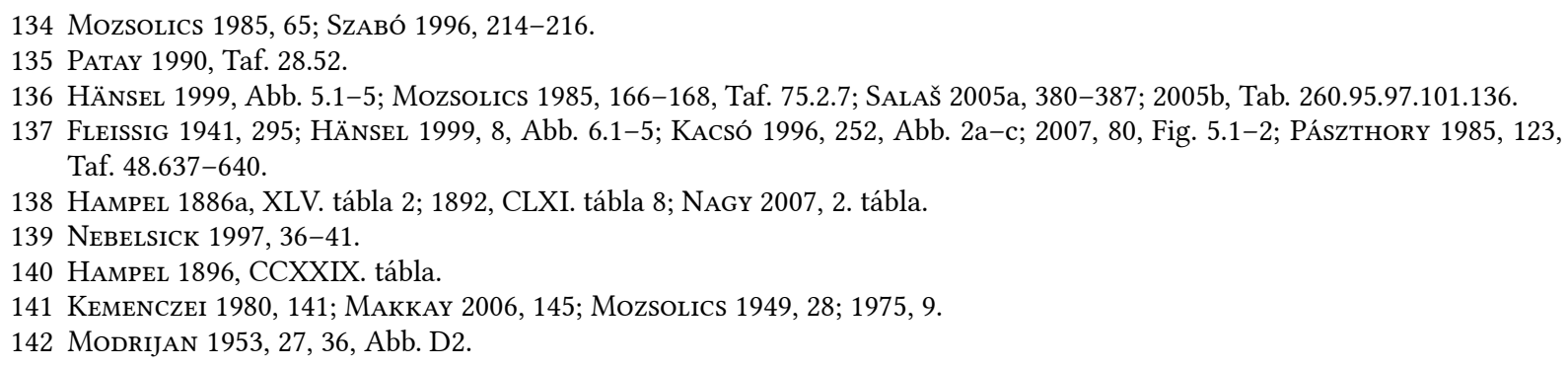




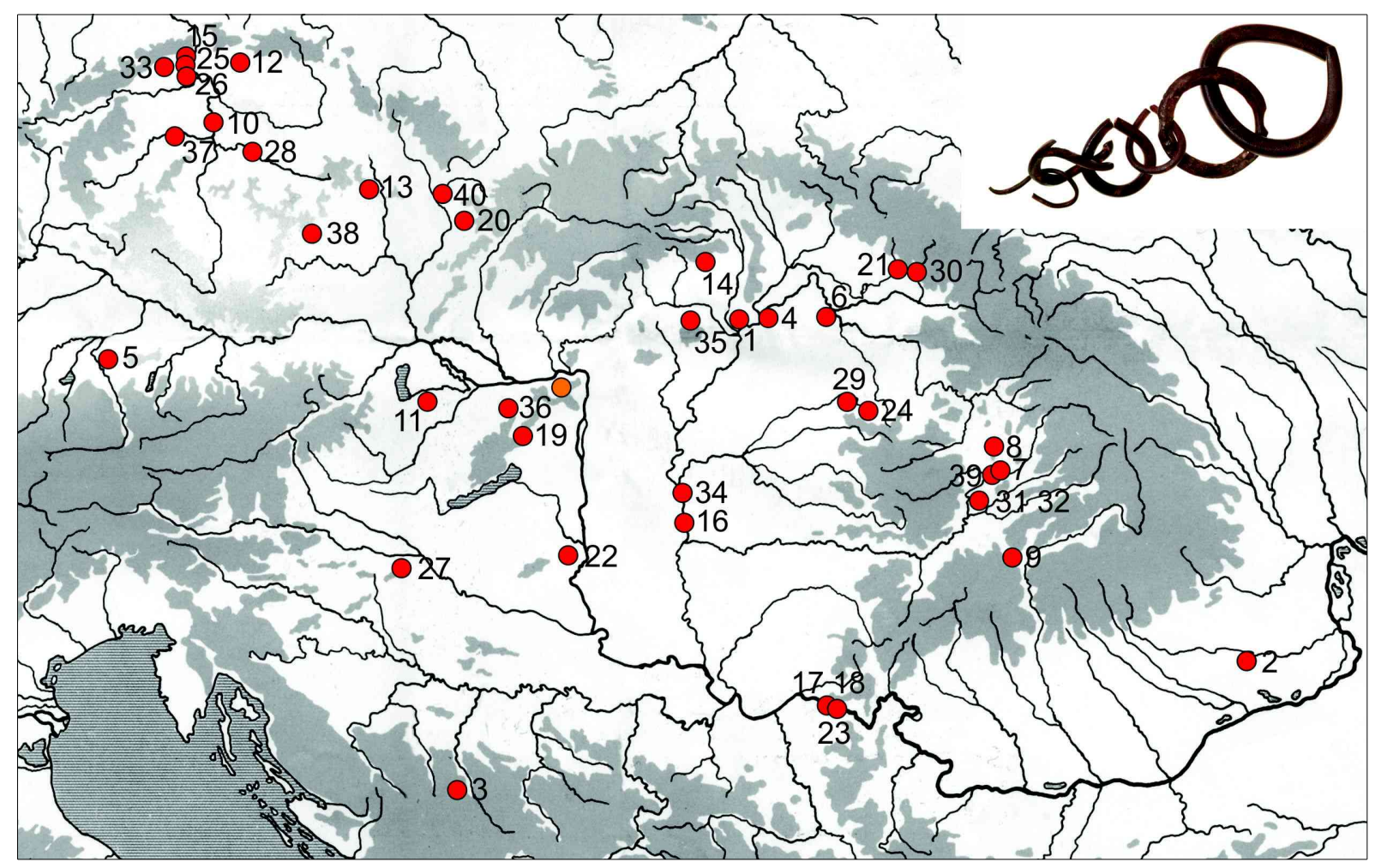

Fig. 29. The distribution of the "chained objects" (List 15).

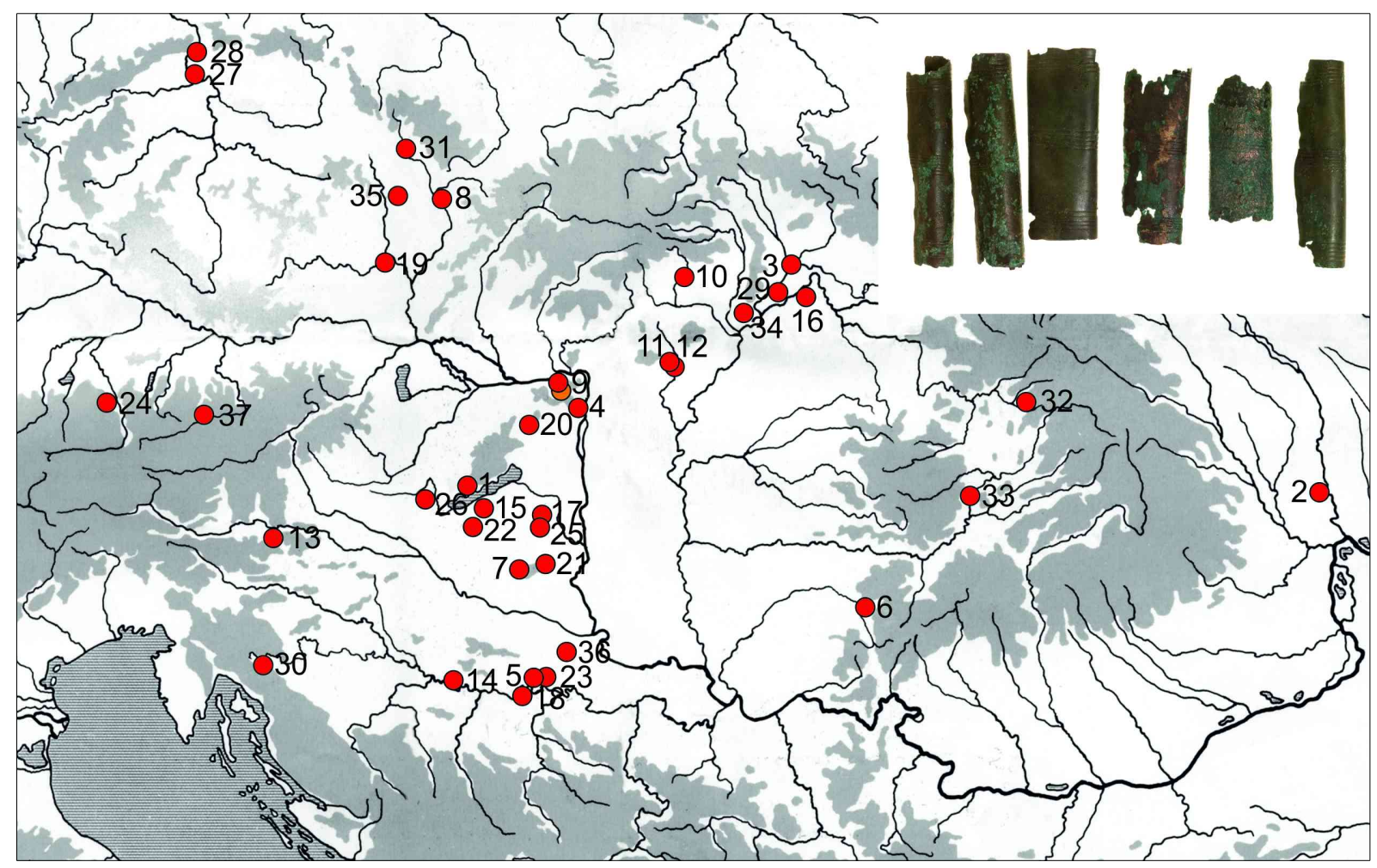

Fig. 30. The distribution of the metal sheet tubes (List 16). 
In connection with this, the jewelry set of the Thunau am Kamp depot should be underlined because it is composed of similar sheet tubes. ${ }^{143}$ Albeit the exact function of these objects are uncertain, their spatial distribution and dating can be well-described. Their first appearance is documented at the Middle Bronze Age (e. g. Puszta-Sárkánytó ${ }^{144}$ ) however they became characteristic between the Ha A1 and Ha A2 stages in Middle and Southern-Europe (List 16, Fig. 30). Most of them are decorated with bundles of lines - similarly to the ones from Kesztölc - but example with decoration of dots (Dražice) and even undecorated ones are also known.

\section{11. Žatec-Type bucket? (Fig. 66.77.1-77.17)}

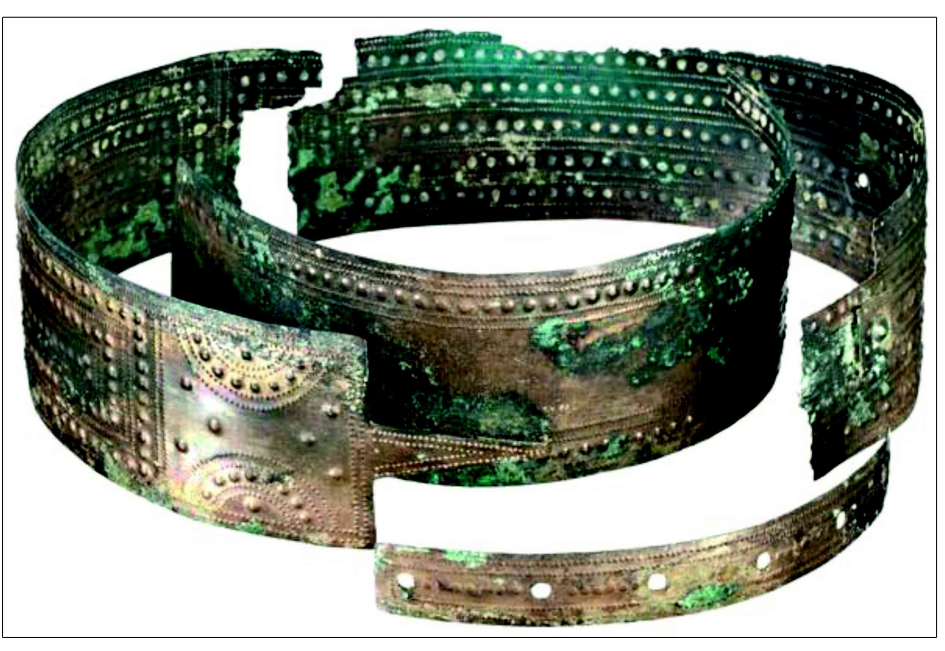

Fig. 31. Belt from Middle-Europe (Hermann Historica), Diameter: $30 \mathrm{~cm}$. http://www.hermann-historica.de/auktion/hhm68.pl?

$\mathrm{f}=\mathrm{NR} \_L O T \& \mathrm{c}=2332 \& \mathrm{t}=$ temartic_A_D\&db=kat68_aw.txt
The depot contains several fragments of thin, metal sheets with embossed decoration. Comparable finds were mainly interpreted as parts of composite armour by the Hungarian research. This hypothesis basically rest on Middle Eastern and Aegean analogies, and it appeared first in monograph of A. Mozsolics wherein these embossed sheets were determined as gorgets (germ. Halsberg). ${ }^{145}$ This type of defensive weapon was an upper part of the scale armour (sariam) and composed of a thin metal sheet riveted onto a flexible organic material. Similar armours primarily distribute in the foursquare closed by Boğazköy, Mykene, Theba and Choga Zanbil. ${ }^{146}$ Besides this, another interpretation is also possible based on formerly found Carpathian and Western European assemblages. At end of the 19th century, T. Lehóczky published a depot from Obava and he interpreted these objects as belts, however the circumstances of discovery referred to a metal vessel: "Az egyik pór megjegyzé, hogy a kősziklák közt egy réz edény látszott, melynek burka azonban a kiszedés alkalmával szétfoszlott s eltöredezett. Mint később meggyözödtem, e rézburok egy övet képezett s összehengerítve lévén, edénynek látszott." 47 It is important to note that prior to his publication, identical sheets riveted onto wooden buckets were known from warrior graves of the Western Urnfield sphere (e. g. Lorscher Wald, Heldenbergen). ${ }^{148}$ Based on the known examples, the evaluation of these objects was carried out by O. Kytlicová and later Ch. Clausing who interpreted them as Žatec-Type composite buckets. ${ }^{149}$ Although the Hungarian research do not take into account

143 Lochner 1998-1999, 184-185, Abb. 4.

144 Foltiny 1955, 20.

145 Catling 1977, 104; Chadwick 1961, 110-111; Jankovits 1999-2000, 193-194; Makkay 2006, 139-140; Mozsolics 1985, 25-26; F. Petres 1982, 61-64, Abb. 11c; ZacCAgnini 1977, 32.

146 Catling 1977, 89-90; Drews 1993, 111; Jankovich 1999-2000, 193-194, Abb. 5; Mozsolics 1985, 25-26; Schauer 1982, 344-345; ZACCAGNINI 1977, 21, 32-33.

147 Clausing 1996, 416; LeHóCZKy 1892, 350-351.

148 Clausing 1996, 414; Behrens 1917, 147-150.

149 Clausing 1996, 413-431, Abb. 6; Kytlicová 1959, 154-155, Obr. 7-9; 1991, 81-82. 
the results of these works and continuously interpreted them as armour, the theory of $\mathrm{O}$. Kytlicová and Ch. Clausing became widely excepted among the Central European research. ${ }^{150}$ In the current study, we follow the results of their works and interpret the fragments of Kesztölc as part of a Žatec-Type bucket. ${ }^{151}$ However, a new belt with similar type of decoration was sold at the auction of Hermann Historica (Fig. 31). Moreover, the fragment from Mačkovac has also identical punched decoration as the previously analyzed sheet belts. ${ }^{152}$ Therefore the determination of the object in question is still under discussion. In my estimation, only the re-publication of the older Carpathian finds and their comparison with the Western European ones can bring us closer to the final solution (Fig. 32).

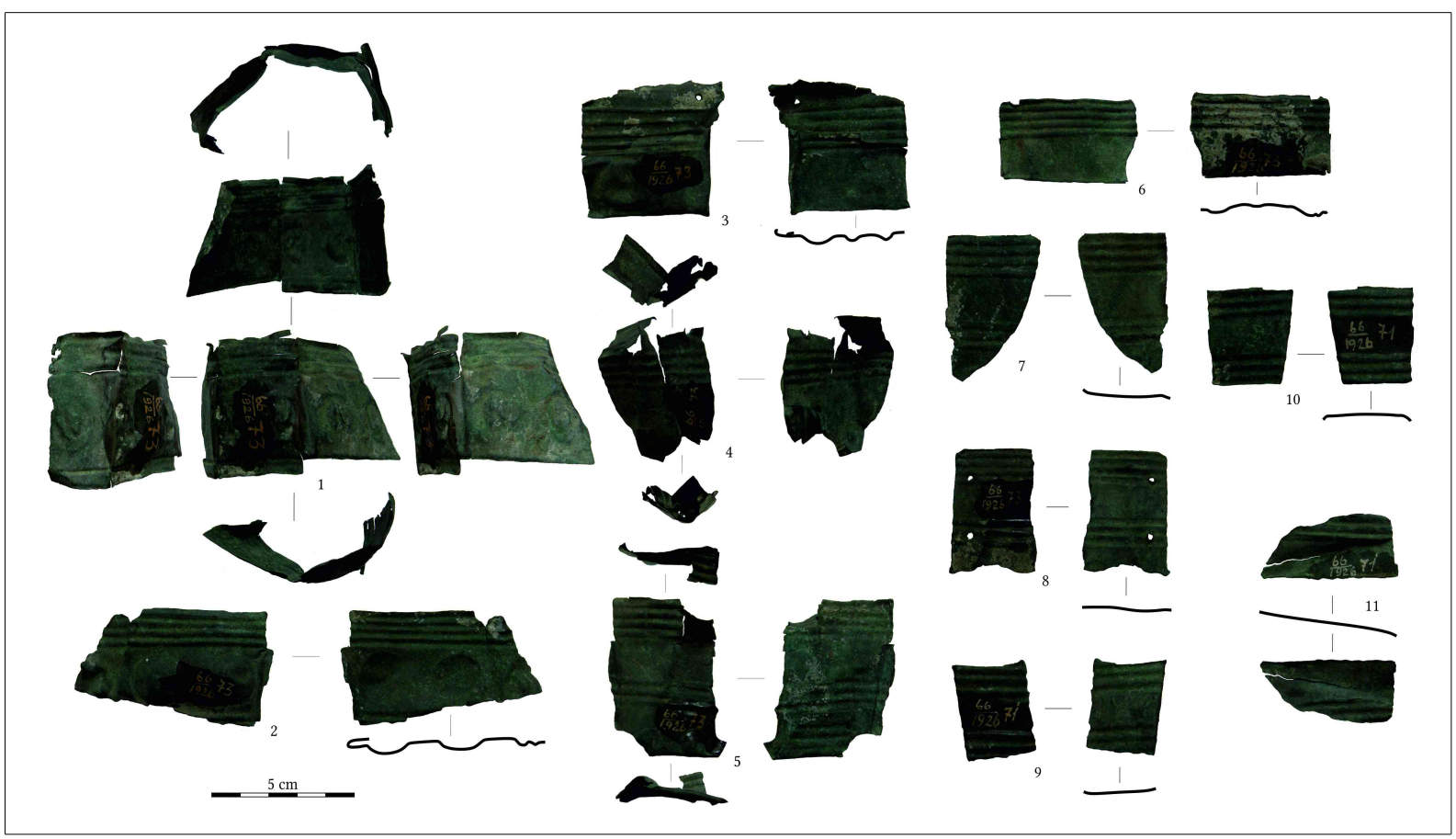

Fig. 32. Žatec-Type bucket fragments from the Keszőhidegkút hoard.

On the case of the Kesztölc depot's fragments - based on its parallels - two different types of reconstruction are possible. It is important to note that its wavy edge is unique and rivet holes were not visible on any of them (Fig. 33). For this reason, it is possible that the metal sheet object from Kesztölc can be interpreted as raw product which had not riveted onto the wooden bucket before its deposition. The Žatec-type buckets mainly distribute in the territory of Southern Germany, Czech Republic, Transdanubia and Croatia. Their easternmost examples are known from Transylvania (e. g. Uioara de Sus) and Ukraine (Obava). They are well-dated to the Ha A, however an uncertain fragment with later deposition (850-650 BC) is known from the sanctuary of Philia (Thessalia) (List 17, Fig. 34).

150 Karavanić 2007, 63; 2009, 134; Karavanić - Mihaljević 2001, 22-23, Tab. 9-10; Makkay 2006, 140, Pl. VI.14, Pl. VII. 15-16, Pl. VIII. 17-30; PAulík 1962, 25-26, 59, Abb. 20.19-34; SoroceAnu 2008, 207, Abb. 33c, Abb. 33d.

151 Problematic is the one from Szentgáloskér which ends are composed of hook and row of holes. Based on its dimensions (length: $39.3 \mathrm{~cm}$, width: $6.10 \mathrm{~cm}$ ) I. Kilian-Dirlmeier excluded the possibility of belt or diadem interpretation. A. Mozsolics and K. Jankovits interpreted it as gorget and É. F. Petres classified it as other armour part. Despite to them, Ch. Clausing grouped it among the category of uncertain buckets. In my estimation, the Szentgáloskér find were pos sibly a modified object and its exact determination is not possible. Clausing 1996, 420; JANkovits 1999-2000, 193-194; Kilian-Dirlmeier 1975, 115, Taf. 48/49.472; Mozsolics 1985, 194-195, Taf. 114.1; F. Petres 1982, 64.

152 Karavanić 2007, Sl. 2. 


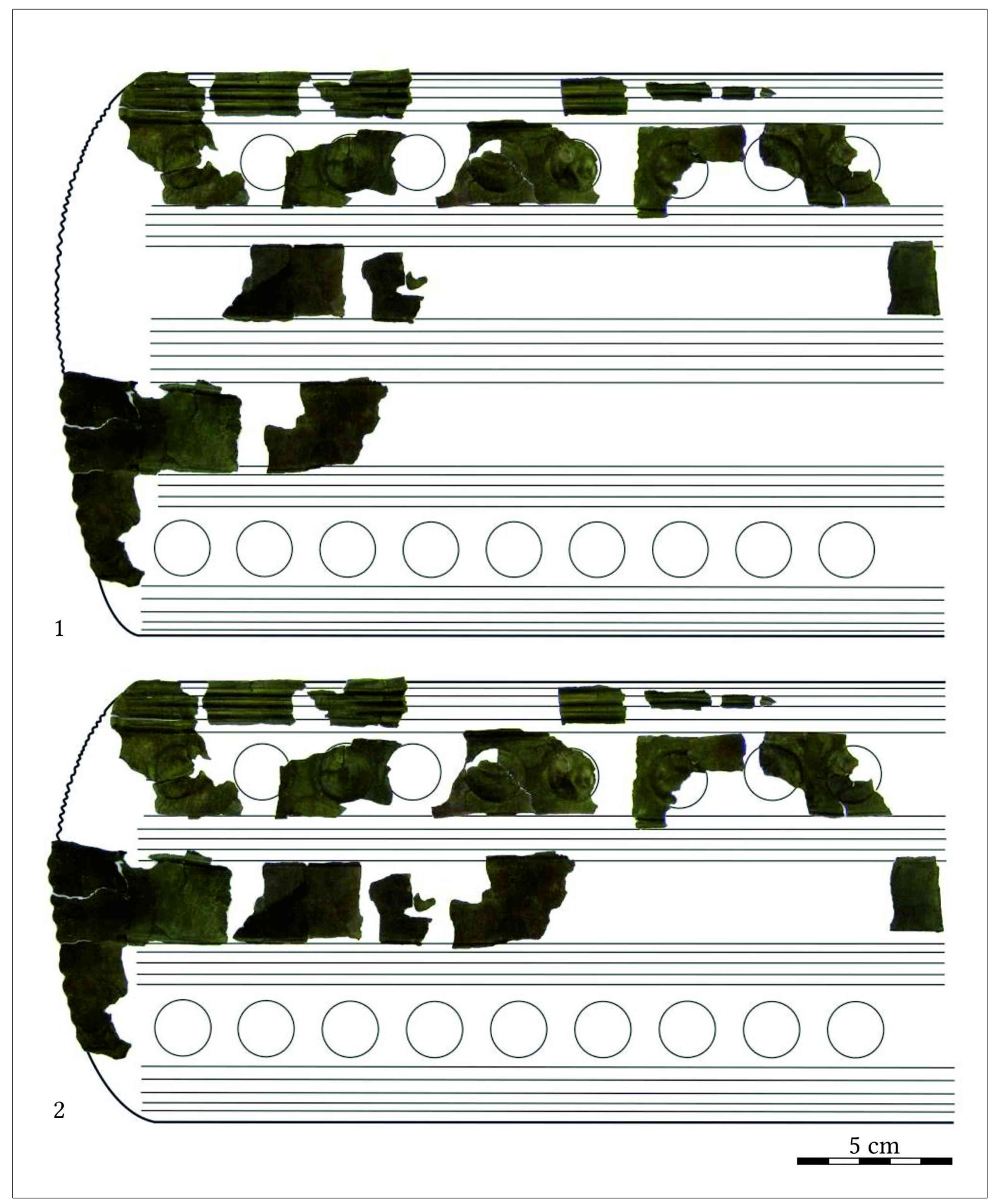

Fig. 33. The two possible reconstruction of the embossed metal sheet fragments from the Kesztölc depot. 
In connection with this it should be noted that similar objects are also appear in the Early Iron Age. ${ }^{153}$ These buckets with ribs-and protrusions decoration were probable a part of a luxury feasting- and drinking set since they often combine with other metal vessel types which spectacular examples are well-known from the elite graves (e. g. Žatec and Očkov) and significant depots (e. g. Kurd, Rinyaszentkirály, Nadap). ${ }^{154}$ In relation to these, it cannot be excluded that they might be used for alcohol consumption similarly to the Scandinavian bark buckets. ${ }^{155}$

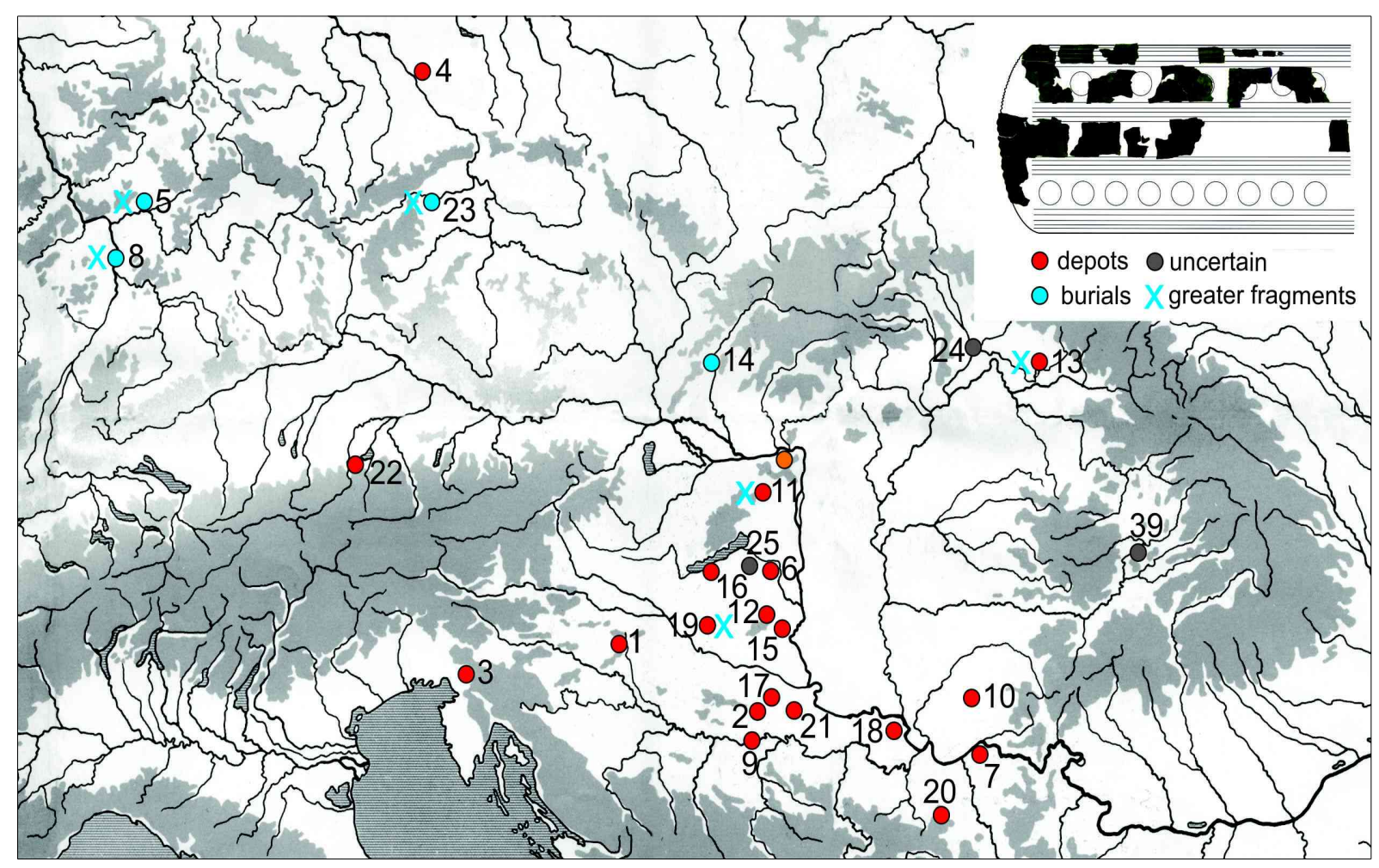

Fig. 34. The distribution of the Žatec-Type buckets and embossed metal sheet fragments from Central Europe.

\section{11. Axe half-from (Fig. 67.78)}

The axe half-form belongs to a group of special objects with uncertain function. Their first example from Kurd was published by J. Hampel at the end of the 19th century who suggested that this object may have been related to the mould manufacturing. ${ }^{156}$ By the $1980 \mathrm{~s}$, their number has been grown, and to this date almost all of the examples from Transdanubia (e. g. Beremend, Keszőhidegkút, Kurd, Lengyeltóti) were published and dated roughly to the same period (Ha A1-Ha A2). ${ }^{157}$ In her classical study, A. Mozsolics interpreted them as test pieces for manufacturing perfectly matching mould shells. ${ }^{158}$ The interpretation of B. Wanzek was similar: he determined them as models for testing the depth and decoration of the moulds. ${ }^{159}$

153 The bucket from Kleinklein should be emphasized because it was suspected that it had similar wooden body as the Late Bronze Age ones. EGg - KrÄMER 2005, 27-30, Abb. 20; Prüssing 1991, 85-87, Taf. 107-121.

154 Falkenstein 2006-2007, 40; Hänsel 1997, 83, Abb. 1; Kytlicová 1991, 82, Taf. 29C; Makkay 2006, Pl. XXX-XXXV, Pl. XXXVI.323-324; Mozsolics 1985, Taf. 96.12; Paulík 1962, Abb. 18, Abb. 20, Abb. 32.

155 MCGOVERN 2009, 144-145.

156 HAMPEL 1896, CCX. tábla.

157 HANSEN 1994, 76, Abb. 73.

158 Mozsolics 1975, 9; 1984, 39.

159 WANZEK 1989, 37-38. 


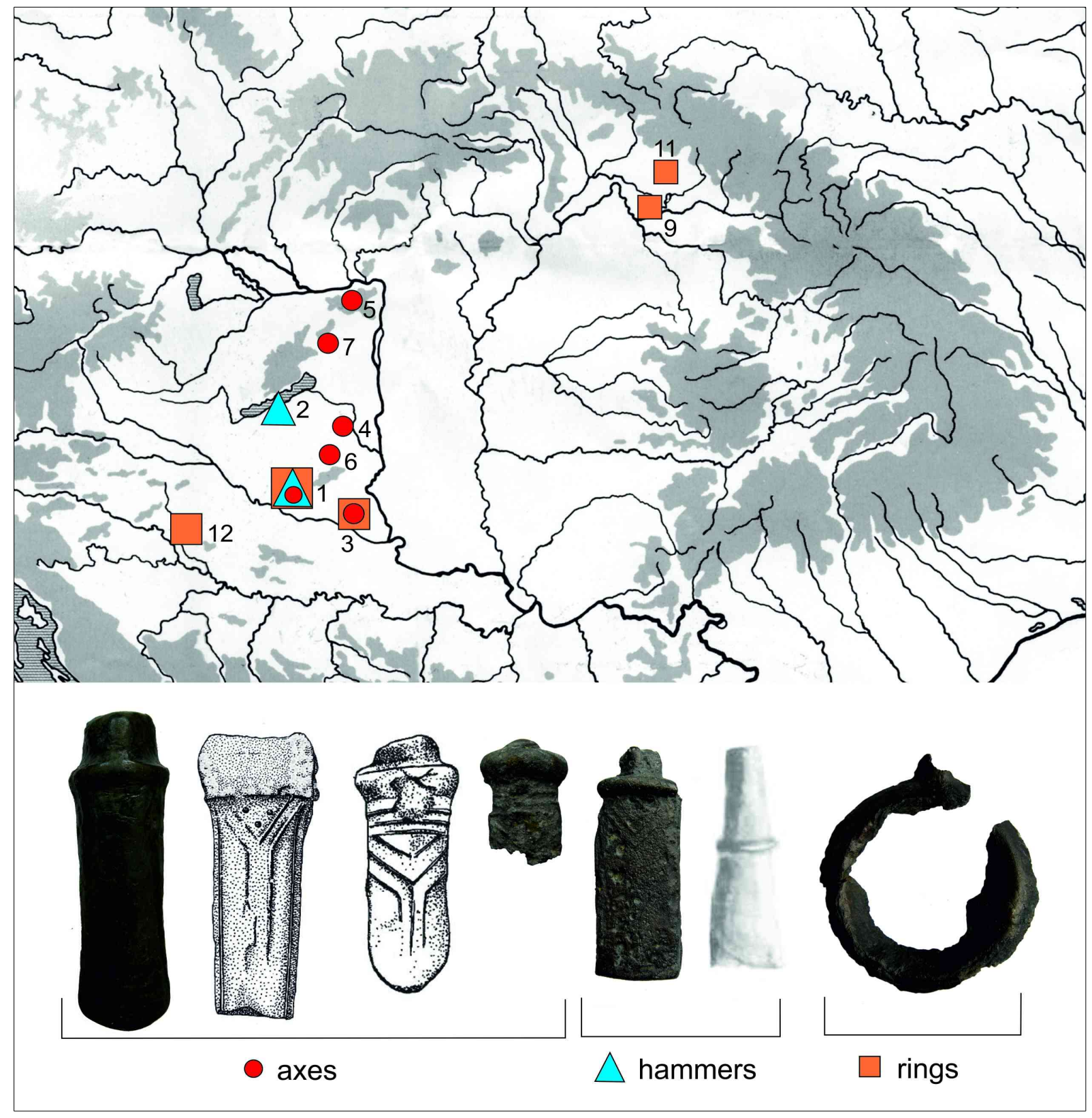

Fig. 35. The typology and distribution of the half-forms (List 18).

In contrast to them J. V. Kobal' interpreted the ring half-form from Malaja Dobron' as an ingot. ${ }^{160}$ It is important to note the opinion of O. Dietrich who drew attention to the width of these objects which is unsuitable for making useable tools. He also pointed out that if these objects were used during the process of casting they might have served for making clay or sand moulds. ${ }^{161}$ To understand the possible function of these objects and to evaluate the axe half-form of the Kesztölc depot, their whole group should be analyzed here in details. The Late Bronze Age half-forms can be divided into three groups: 1.) hammer half-forms; 2.) axe half-forms; 3.) ring half-forms (List 18, Fig. 35). These artefacts first appeared among the Transdanubian Ha A1 depots. Although, they mainly distributed in this area, some of them appeared beyond this region. Moreover, their analogies show a much more complex picture. 

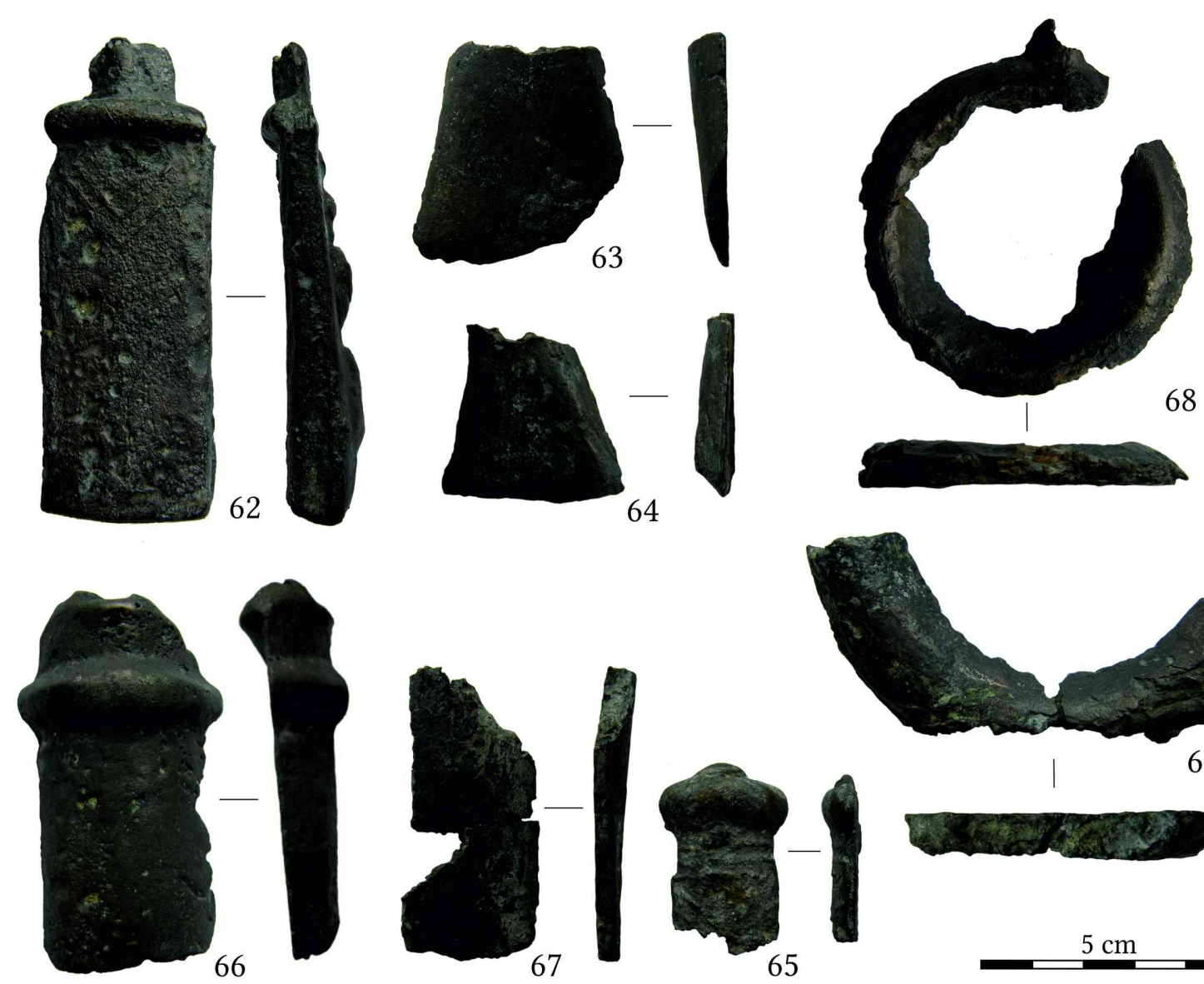

8

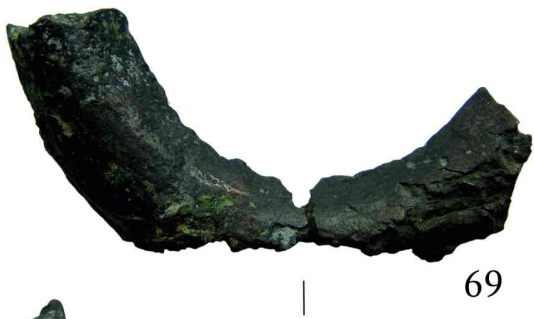

Fig. 36. The half-forms from the unpublished Nagydobsza depot.

Based on their features we sorted the two half-forms of the Lengyeltóti 3 depot into the first group. ${ }^{162}$ Their exact analogies can be found in the unpublished Nagydobsza depot (Fig. 36). ${ }^{163}$ Furthermore, a mould for manufacturing identical objects is known from Velem. ${ }^{164}$ Due to its unique features like the thickened mouth and triple V rib decorations the No. 62 object of the Nagydobsza depot should be underlined. Its mould parallels are well-known from Tiszaföldvár and Zvoleněves. In addition, similar hammers can be found among the depots of Aiud, Lengyeltóti 2 and Boljanić (Fig. 37). However these finds are slightly different in fine details and dimensions from the hammer half-form of Nagydobsza. ${ }^{165}$ Comparable finds to axe half-form of Kesztölc are known from the depots of Kurd and Nagydobsza and re cently a picture of a new example has been uploaded on a metal detectorist blog (Fig. 38-39). It is important to note that these finds' morphology and dimensions are strongly resembled to each other. ${ }^{166}$

162 Gy. Török interpreted them as knife like bronze lumps. Later, A. Mozsolics was the first who classified these objects among the group of axe-half forms. TöRöк 1940, 62; Mozsolics 1975, 9. Based on their quadratic cross section and hammer like face, these objects are fall closer to the group of hammer half-forms. This classification is also supported by several hammer parallels from the Carpathian Basin: e. g. Lovasberény, Nagydém, Somotor. HAMPEL 1896, CXCV. tábla 2; Mozsolics 1985, 144-145, Taf. 245.6; NovotnÁ 1970b, 99, Taf. 43.805.

163 The depot from Nagydobsza was first evaluated within the framework of my MA thesis. Here, we only would like to publish the half-forms of the depot. TARBAY 2013, 174-263, 495-522, Katalógus B, 1-92. tábla.

164 Miske 1907, 26, XXII. tábla 3.

165 GogÂltan 2005, 346, Taf. I.3; KöNIG 2004, 192, Taf. 17.38; WAnZeK 1992, Taf. 8.6.

166 Kesztölc (lenght: $15.3 \mathrm{~cm}$ ), Kurd (lenght: $14.1 \mathrm{~cm}$ ), Nagdobsza (lenght: $7.6 \mathrm{~cm}$ ). 


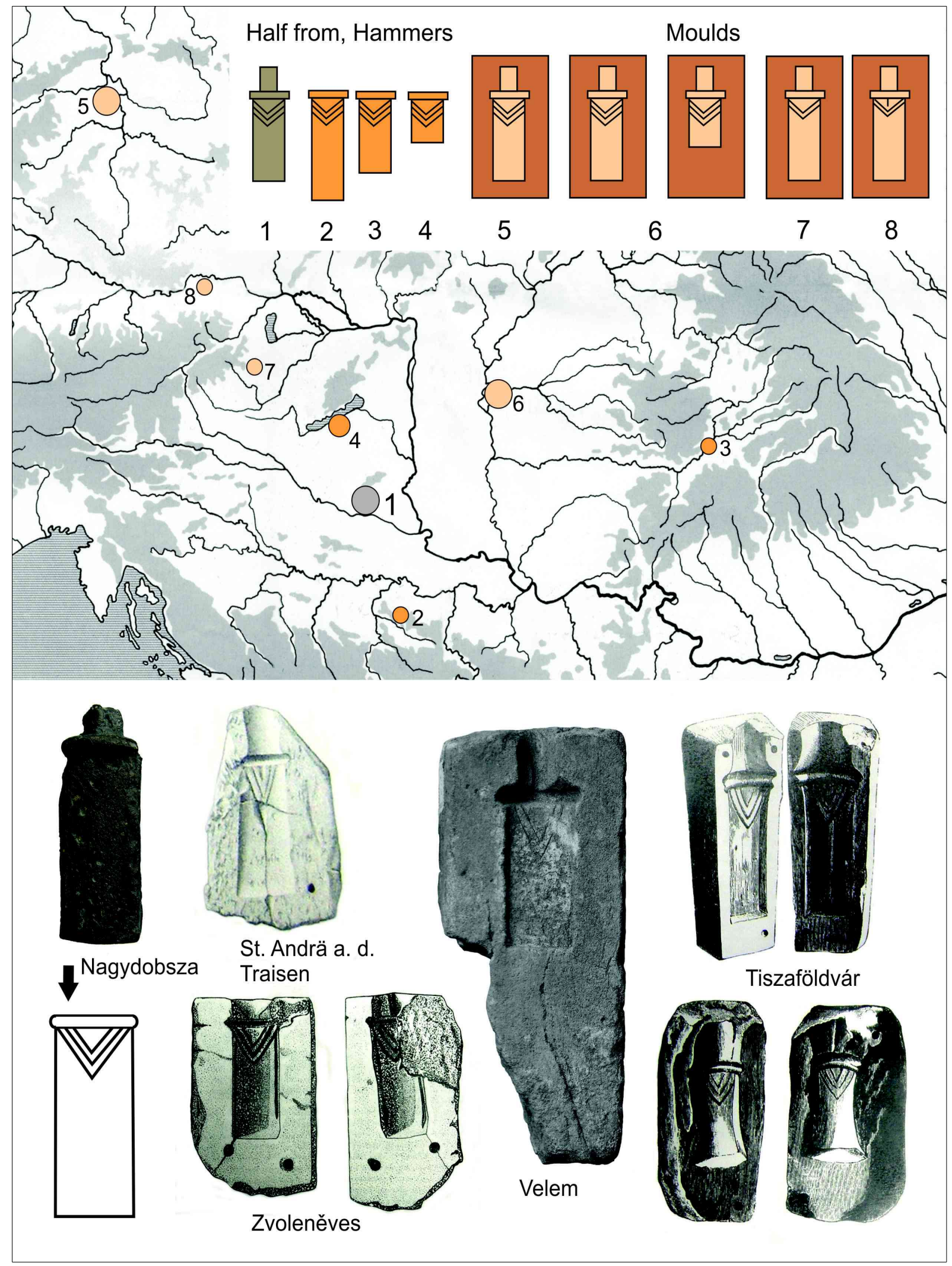

Fig. 37. Positive and mould analogies of the No. 62 axe half form from Nagydobsza (List 18). HAMPEL 1886a, IV. Tábla 4-5, 9-10; Hralová - Hrala 1971, Obr. 4.2; Mayer 1977, Taf. 89.1329; Miske 1907, Taf. XXIV. 


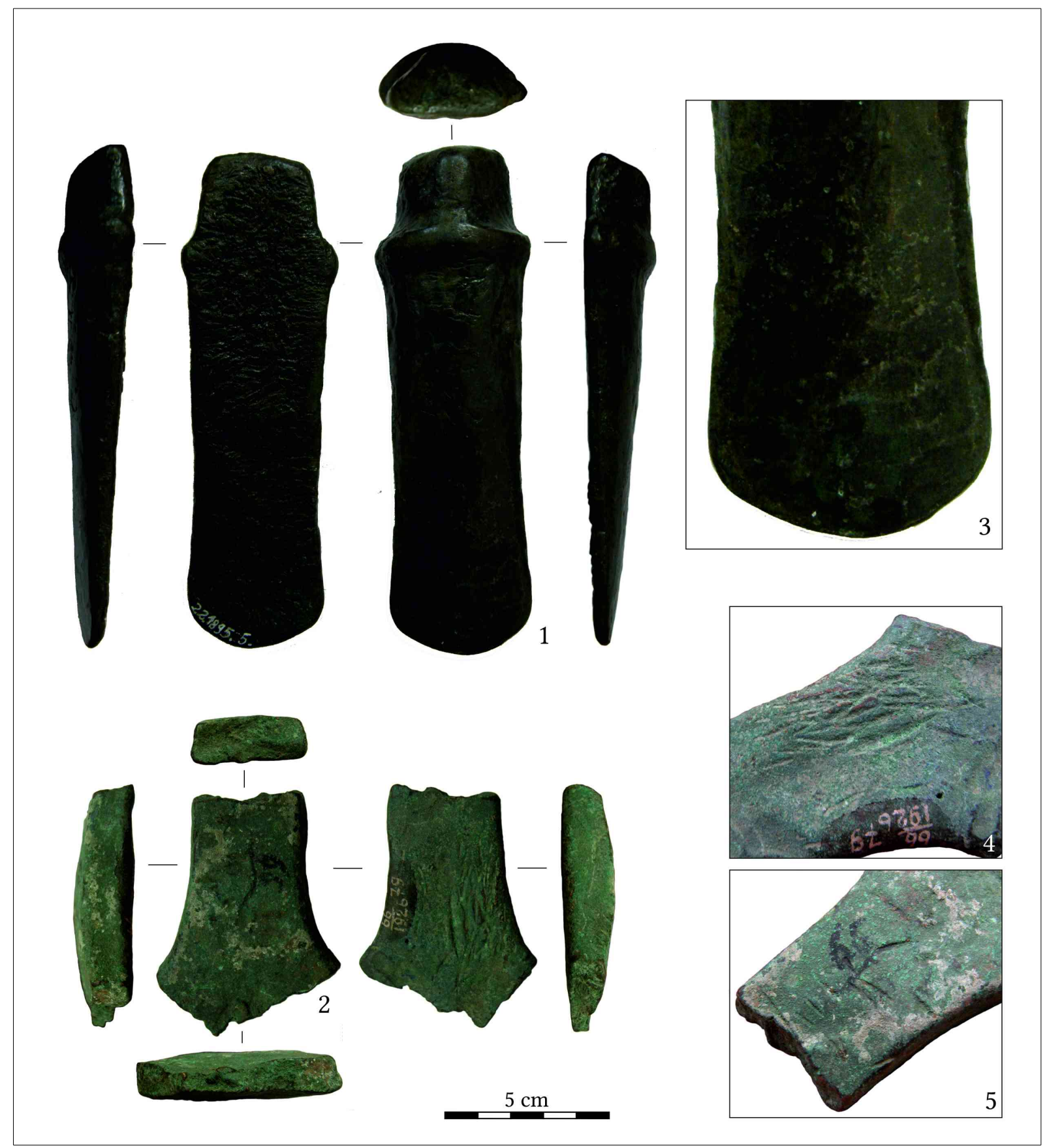

Fig. 38. 1. The axe half-form from Kurd 2. The axe half-form from Keszőhidegkút.

From typological point of view, their dating closes a relatively short period. The oldest is the one from Kurd (Ha A1) however the other two can be dated to the Ha A2/B1 stage. Different type of axe-half form is also known from the Nagydobsza depot ${ }^{167}$ which is analogous to the find from Beremend. Despite that it is a miniature form (No. 65) its patterns (Y and horizontal ribs) are similar to the earlier analyzed socketed axes (Fig. 11, Fig. 36.65). ${ }^{168}$ Further axe half-forms are known from the Keszőhidegkút depot from which the one with rib decorations should be underlined. Similar socketed axes are dominated mostly in the region of the

167 Further examples are known from the Nagydobsza depot although the parallels of these fragments cannot be determined. 168 Mozsolics 1985, 95-96, Taf. 252.5. 
Southern Carpathian Basin. ${ }^{169}$ The parallels of the other one from Keszőhidegkút are hard to determine due to its fragmentary state, however examples with identical features are wellknown among the Carpathian socketed axes (Fig. 38.2).

The ring half-forms are mostly known from uncertain context (e. g. the one from "Hungary") and Ha A2 depots (e. g. Beregovo 4, Beremend, Kloštar Ivanić, Nagydobsza No. 68, No 71) (Fig. 36. 68-69). ${ }^{170}$ It is important to note that a mould from Velem can be associated with the manufacturing of this half-form type. ${ }^{171}$

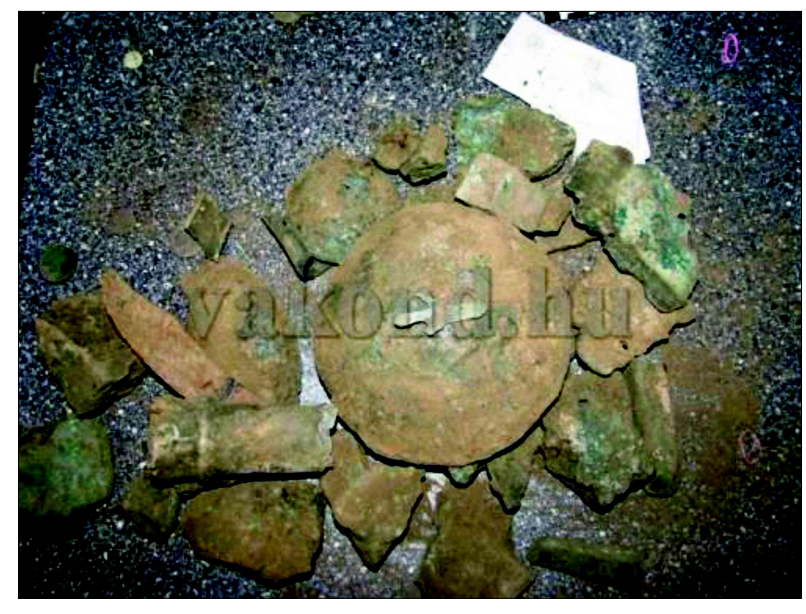

Fig. 39. Depot from unknown location with similar axe half form as Kesztölc. http:/www.vakond.hu/lexicon depo.htm (2003. 03.01).

In regards to the probable function, I agree with the opinion of O. Dietrich that these objects are unsuitable for manufacturing useable tools. This statement can be well supported by the miniature axe half-from of Nagydobsza and the half-forms' exact dimensions. It is also notable that none of the axe half-forms are equipped with loops. Moreover, clear traces of casting faults and a re-melted casting jet (Nessel's Type I.2) can be observed on the surface of the hammer half-form from Nagydobsza. Therefore this artefact is not just unsuitable to manufacture moulds but it could have been casted from re-melted materials. ${ }^{172}$ More confusing are the hammering traces on the surface of Kurd axe half-form. Up to now, comparable phenomenon was only observed on the surfaces of finished products. It is important to note the damage traces on the Keszőhidegkút axe half-form. Comparable mark can be observed on the surfaces of plano-convex ingots or socketed utensils and weapons. Based on the aforementioned features, two distinct statements can be formulated on the function of the analyzed artefacts: 1.) the half-forms can be determined as semi-finished products and probable were made of re-melted materials. 2.) the manufacturing of these objects might have related to the event of deposition, therefore they could bare symbolic function as well.

\section{12. Rod ingot (Fig. 67.79)}

The depot contains only one fragment of a rod ingot. These bronze or gold semi-finished products appeared at the Middle Bronze and were manufactured by moulds (e. g. Aszód, Füzesabony). Their form are various even in the context of one assemblage, for this reason their morphological typology may not be necessary. ${ }^{173}$ Similar Late Bronze Age examples to the Kesztölc depot's ingots are distributed over the whole territory of the Carpathian Basin and its adjacent regions between the $\mathrm{Br} \mathrm{D}$ and Ha A1 stage (List 19, Fig. 40).

169 The parallels of the half-form of Keszőhidegkút: Bodrogkeresztúr, Budinščina, Čermožiše, Donja Dolina, Gornji Log, unknown (Archaeological Museum Split), Motke. It should be emphasized that the decoration of the ones from Motke und Gornji Log are slightly different. ČERČE - ŠINKOvEC 1995, 138-147, 169-170, Pl. 43.9, P. 69.2; GAvRANović 2011, 135, Abb. 133.2; Kemenczei 2003, Taf. 1.4; König 2004, 211-212, Taf. 26.21; Mozsolics 1985, 135-137, Taf. 35.1; VinsKIGasparini 1973, 212, Tab. 78.7; Žeravica 1993, 95, Taf. 36.488.

170 Hampel 1886a, I. Tábla 4; Kobal’ 2000, 74, Taf. 46B.2; Mozsolics 1985, 254, Taf. 254.2-4; Vinski-Gasparini 1973, 215, Tab. $96.15-18$

171 MisKe 1907, XXIII. tábla 8.

172 Nessel 2012a, 14.

173 Czajlik 2012, 74; Dietrich 2009, 100; Hampel 1886a, 186; Kobal’' 2000, 70-71; Mozsolics 1985, 32. 


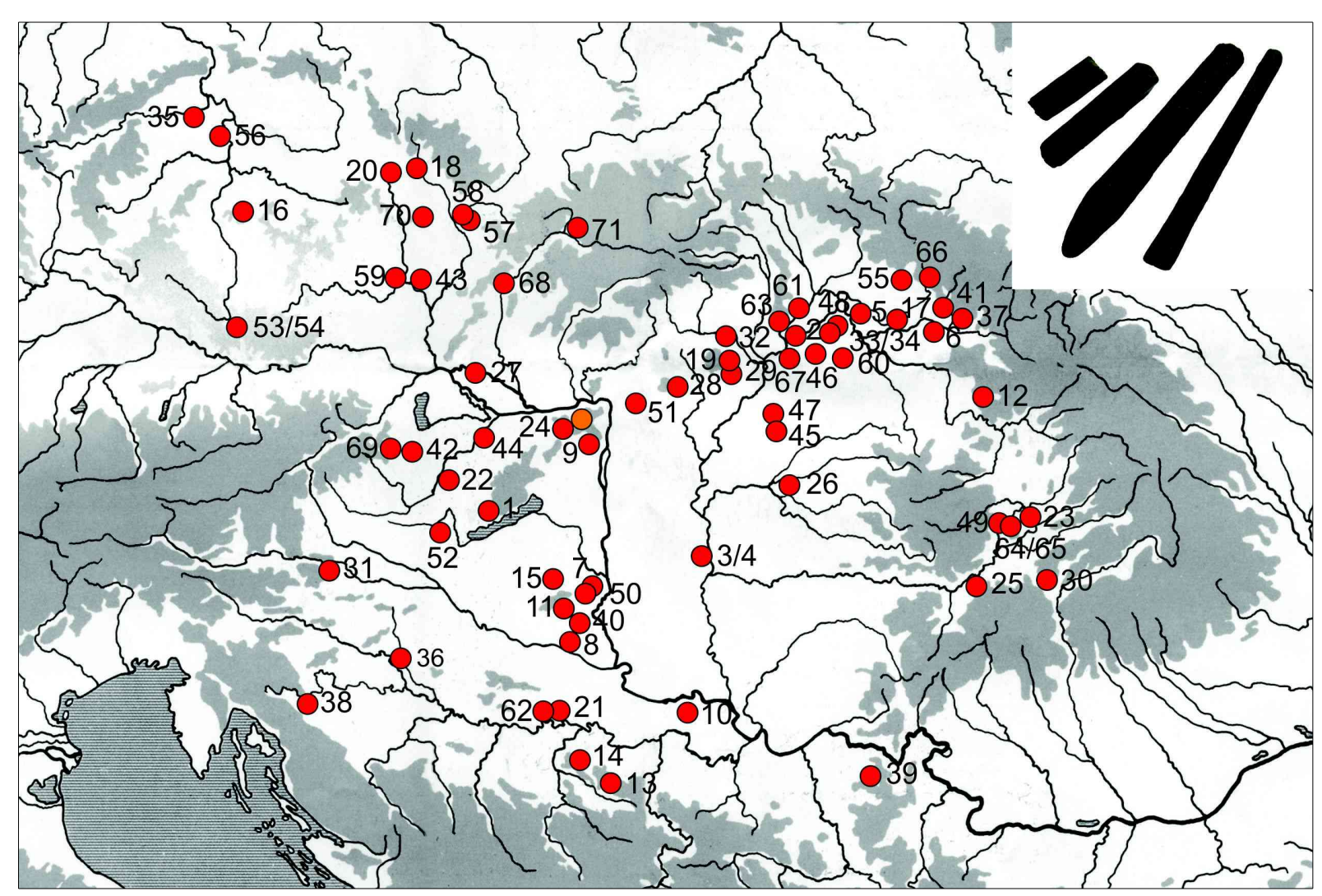

Fig. 40. The distribution of the rod ingots (List 19).

III. 13. Plano-convex ingots (Fig. 68.80, Fig. 69.81, Fig. 70.82-83, Fig. 71.84, Fig. 72.85, Fig. 73.86-88, Fig. 74.89-94)

The Kesztölc depot contains four smaller and eleven larger fragments of plano-convex ingots. ${ }^{174}$ From the classification schemes of these semi-finished products, the works of $\mathrm{M}$. Rusu, A. Mozsolics and Z. Czajlik should be emphasized. ${ }^{175}$ While M. Rusu's typological system dealt with the dimensions (e.g. length of cross section, weight), A. Mozsolics sorted them into two formal groups: leaky plano-convex ingots and convex ingots. ${ }^{176} \mathrm{~A}$ new techno-typological scheme was established for the Transdanubian examples by Z. Czajlik. His classification is based on formal features, exact metrical data and the alloy composition of this ingot type. ${ }^{177}$ Although grouping the Kesztölc depots plano-convex ingots into his scheme is problematic, the below analysis practically follows his work. Based on its cross section No. 80 is classifiable into the Nyergesújfalu-Type, although its total weight cannot be more than $4 \mathrm{~kg}$ which is rather characteristic to the Velem-Type. Similar is the problem with No. 85 and No. 81. They can be linked to the group of high plano-convex ingots (UjfaluType) although it is highly unlikely that their weight were $8 \mathrm{~kg}$. Despite the above discussed problems No. 82 could be linked to the Velem Type and No. 84 to the group of small planoconvex ingots of Lovasberény-Type. Due to its fragmentary state No. 83 are hard to classify,

174 Fragments No. 87-93 are unsuitable for typology due to their fragmentary state.

175 Érdy 1861, 38; Hampel 1896, 180; KobaL’ 2000, 70; Kytlicová 2007, 162; LÁzÁr 1943, 240; Menghin 1937, 71; MisKe 1907, 57; Angeli - Neuninger 1964, 77; Pulszky 1883; 1897, 132; Pittioni 1941, 81; 1967, 66; TÉGlás 1885, 106; 1887, 116; 1891, 214; ТомPA 1923-1926, 41; Wosinsky 1896, 216.

176 Mozsolics 1984, 35-38; Rusu 1981, 382.

177 Czajlik 1996, 166-174, Abb. 20; 2012, 67-71; CZajLik et AL. 1999. 
however it was possibly a part of a high plano-convex ingot. ${ }^{178}$ From chronological point of view, these types were deposited for a long period of time. The Velem-Type belongs to the $\mathrm{Br}$ D-Ha A1 stages, although the Nyergesújfalu-Type has a later dating: Ha A-Ha B. The Lovasberény-Type has the longest deposition from the $\mathrm{Br} \mathrm{D}$ to the Ha B1 stage. ${ }^{179}$

As for their technological aspects, the quality of the analyzed plano-convex ingots is quite diverse. Examples with smooth breakage surface and ones with inferior quality can be equally found among them. Crater like traces of gas bubbles and porous breakage surface are also visible on some examples. ${ }^{180}$ It is worth to mention that in three cases (No. 82, No. 85, No. 88) the trace of layered casting was documented. Comparable phenomenon which was related to the early manufacturing stage of this ingot type was only documented along the breakage surfaces of the ones from Velem and Trieben Versunkene Kirche. ${ }^{181}$ Significant is the fragment No. 80 on which a re-casted spiral ring could be well-observed. Analogous phenomenon is wellknown from other plano-convex ingots of the Carpathian Basin (e. g. Bodrogkeresztúr 3). ${ }^{182}$

\section{14. Tube with widened rim (Fig. 75.95)}

The object in question (No. 95) belongs to a special group of artefacts which exact function is not entirely clarified. They were described either as parts of pendants, helmets or as wagons. ${ }^{183}$ However, according to Ch. Pare they were most likely wagon barriers. ${ }^{184}$ These small bronze tubes with disc- or stepped like rim are distributed from the Carpathian Basin to Northern-Europe. In certain cases, a bronze rod was pulled through their body which feature could support the wagon barrier theory. ${ }^{185}$ Some of them are decorated with bundles of lines (e. g. Přestavlky) or with pine-needle like patterns (e. g. Lengyeltóti). ${ }^{186}$ These tubes dominated between the $\mathrm{Br} \mathrm{D}$ and $\mathrm{Ha} \mathrm{A} 1$ stages, but later examples are also known from the Ha B3 and the Early Iron Age (List 20, Fig. 41). ${ }^{187}$

\section{15. Casting Jets (Fig. 75.96)}

The two casting jets of the depot belong to a metallurgical by-product group which has been well-known since the 19th century. ${ }^{188}$ Their quantity is relatively low in Central but even in Western and Northern Europe. Most of them were parts of depots, only their small quantity is known from settlements and graves. ${ }^{189}$ Based on its confusing features (e. g. the breakage on its upper part, the unpolished casting seams and the slight horizontal shift of its sides) No. 96 can be interpreted as a failed casted object. However its upper part strongly reminds to the casting jets of Nessel's I.1. group. ${ }^{190}$ The classification of the other example (No. 97) is easier. Based on its semi-circle cross-section it is sortable into Nessel's I.2 group. ${ }^{191}$

178 CZAJLIK 2012, 68-71.

179 CZАJLIK 2012, 68-70.

180 CZAJLiK 2012, 96-97; Mozsolics 1984, 37.

181 CzAJLiK 2012, 64.

182 CZajlik 2012, 72; Mozsolics 1984, 35-37.

183 WANZEK 1992, 263.

184 PARE 2004, 360.

185 Mozsolics 1985, Taf. 97.16; ŠAlas 2005b, Tab. 265.165-166, Tab. 266.167; SAlAš-ŠMid 1999, 32, Abb. 10-22.

186 Šalas 2005b, Tab. 265.162; Wanzek 1992, 263, Taf. 1.16, Taf. 10.14.

187 PARE 2004, 360.

188 Hampel 1896, 190, 199; Jantzen 2008, 226-236; Kujjpers 2008, 92; Miske 1907, 59-60, XXVI. tábla 14-15; Mozsolics 1984, 27-28, Taf. 13.7; NesSel 2012, 151-154, Abb. 10-15; WANZeK 1989, 46-49, 60-65, Abb. 5.

189 HANSEN 1994, 134-135, Abb. 74; NesSel 2012, 145, 151-154, 158, Abb. 10-15.

190 NeSSEl 2012, 146, Abb. 1 b.

191 NeSSEL 2012, 147, Abb. 2. 


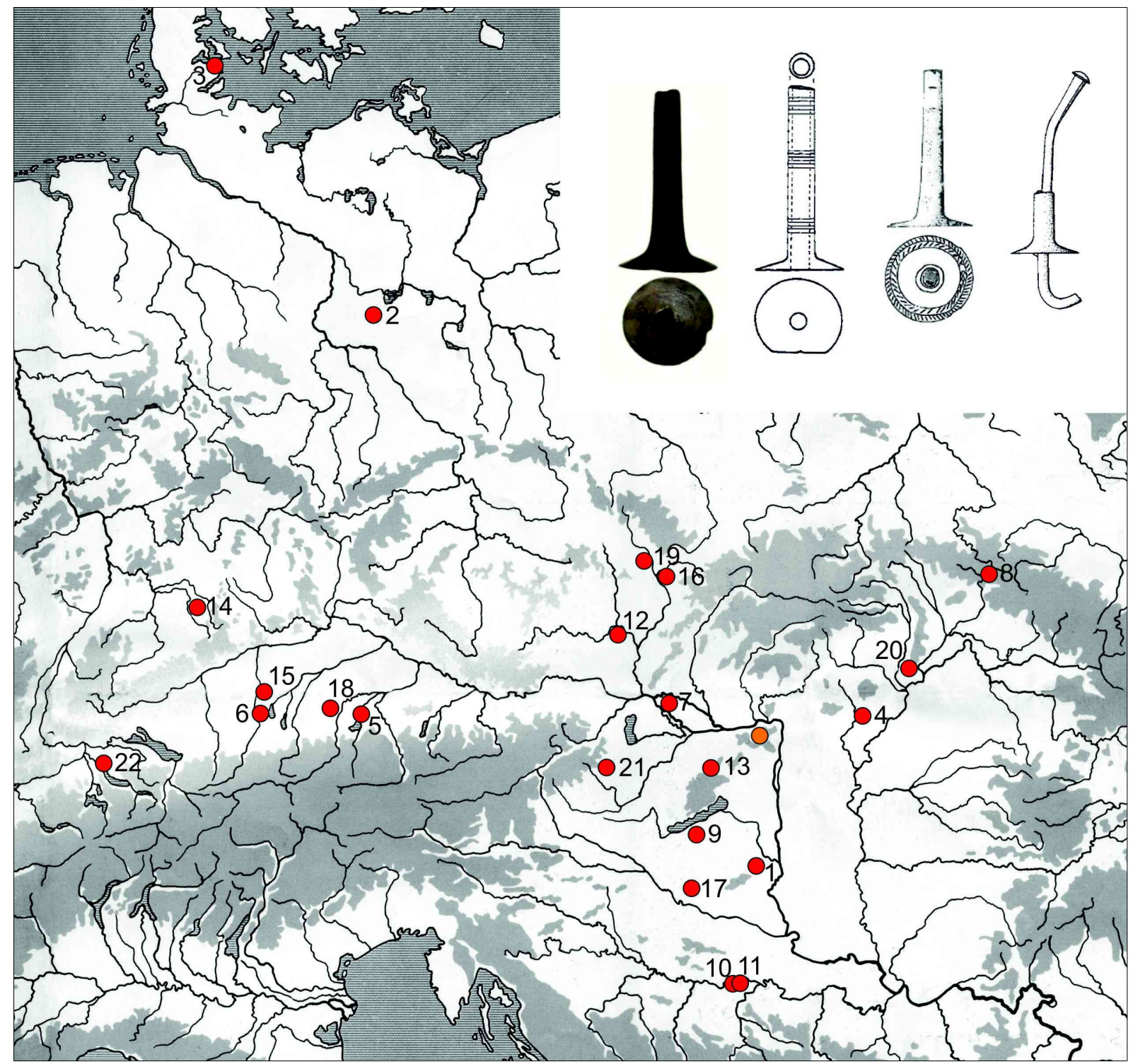

Fig. 41. The distribution of tube with widened rim

(Mozsolics 1985, Taf. 107.22; SAlaš 2005b, Tab. 265.162, Tab. 266.167; List 20).

\section{16. Wire fragments (Fig. 76.97-99)}

The depot contains three, square-sectioned wire fragments. Their exact function cannot be determined due to their uncharacteristic form. They were probably parts of a larger object (e. g. fibula).

\section{17. Fragments of Socketed Utensils (Fig. 76.100-106)}

By reason of their fragmentary state, the seven fragments of socketed utensils (No. 101-106) are unsuitable for further typological or technological analysis.

\section{18. Button or Belt-Hook (Fig. 76.107)}

Due to its confusing form and the casting flaws on its exterior surface the No. 107 object is hard to classify. On the basis of its small hook it can be interpreted either as a button or as a belt-hook. 


\section{Conclusions}

On the basis of the typo-chronological analysis it may be said that most of the analyzed objects can be dated to $\mathrm{Ha} \mathrm{A} 1, \mathrm{Ha} \mathrm{A} 2$ or Ha B1 stages. It is also possible to differentiate a dom inant "older" Ha A1 group (e. g. Žatec-Type bucket, metal sheet tubes etc.) from another which is composed of "younger" objects (Ha A2/B1) such as the spear or the socketed axes. Based on these results, the depot had a long period of cumulation (Fig. 42). Despite that it contains many Ha A1 related objects its "younger" finds can be well-linked to the Ha B1 stage. Thereupon, if we follow the typo-chronological models of the Hungarian research, it can be concluded that the depot was buried in the Ha A2 stage (Gyermely horizon/Hoard Find Stage III). ${ }^{192}$ But, was the depot from Kesztölc really buried during the Ha A2 transitional stage?

The current "metal typo-chronology" of the Carpathian Basin is practically composed of country-related chronological schemes which are connected to each other and to P. Reinecke's and H. Müller-Karpe's systems. ${ }^{193}$ The Ha A2 problem itself can be traced back to end of the 1950s when H. Müller-Karpe established his classical chronological frame. Based on crossdating with the Mediterranean and the Middle East, and the seriation of the metal finds from cemeteries of Southern Germany, he was able to develop further Reinecke's system and divided the Ha A into Ha A1 and Ha A2 stages. ${ }^{194}$ However, he emphasized that the Ha A2 stage can only be evinced in certain territories of Europe. Moreover, its characteristic objects such as the Fuchsstadt-Type cups can be linked to the younger stage (Ha B1) as well. ${ }^{195}$ The second greatest influence on the Eastern Central European chronology was W. A. von Brunn's classical monograph, in 1968. His principal was that despite the lack of metal artefacts from cemeteries of the Carpathian Basin, the quantity of the metal objects in the depots is enough to establish a chronological scheme for this region. Thereupon, he differentiated four stages and paralleled them to Müller-Karpe's system. ${ }^{196}$ This "depot chronology" distinguished the stages by combination of artefacts, cross-dating and the appearance of new types and stylistic variants. The so called Jászkarajenő-Uzsavölgy stage (Ha A2) is the best example of this method because it is composed of "older" and "younger" objects such as the currently analyzed depot from Kesztölc. ${ }^{197}$ After W. A. von Brunn's work, the Carpathian research established local chronological schemes which also included the Ha A2 stage despite the fact that most of the researchers were well-aware of its uncertainties. ${ }^{198}$

A. Mozsolics was one of them when she defined the Gyermely horizon (Ha A2) by objects which can be linked to the following stage (Ha B1). However, she stressed that this horizon can only be determined by typological analysis and cannot be cross-dated like the Kurd horizon. ${ }^{199}$ In 1994, S. Hansen was the first who formulated a different opinion on the dating of the aforementioned horizon. According to him, the "Gyermely-Type hoards" can be defined

192 KeMENCZEi 1996; MozSOlics 1985.

193 von Brunn 1968; Dergačev 2002; Foltiny 1955, 111, 117-122; Harding 2000, 9; Kemenczei 1996; Kobal' 2000; MoZSOlics 1943, 4-8; 1985; 2000; MÜller-KarPe 1959a; Petrescu-Dîmboviţa 1978; Reinecke 1899; 1900; 1902; VinskiGASPARINI 1973; VASIĆ 1982.

194 MÜLlER-KARPE 1959a, 153-160.

195 MÜLlER-KARPE 1959a, 161, 198, 200-204.

196 VON BRUNN 1968, 28-29, 51.

197 VON BRUNN 1968, 46-50, Abb. 3.

198 Gavranović 2011, 30-31; Kobal' 2000, 14-15, Abb. 1; König 2004, 91, Taf. 3; Mozsolics 1985, 82-84; NovotnÁ 1970a, Tab. 1; Petrescu-Dîmboviţa 1977, 24-25, 31; Petrescu-Dîmboviţa 1978, 92; Rusu 1963, 190, 208, Abb. 3; VAsić 1982, 267-268, 273-274, 281-282; KARAVAnić 2009, 92; Vinski-Gasparini 1973, 196, 205-206.

199 Mozsolics 1985, Taf. 278. 
as a Transdanubian depot group rather than an independent chronological stage. ${ }^{200} \mathrm{He}$ also drew attention to the fact that the characteristic types of the Gyermely horizon are different from the objects of Müller-Karpe's Ha A2 stage, therefore their comparison is highly problematic. ${ }^{201}$ S. Hansen practically dated the Gyermely-Type depots into the Ha B1 stage by referring to socketed axes with ribbed decoration and to other artefacts. ${ }^{202}$ The first reflection to his work is related to T. Kemenczei who virtually re-evaluated A. Mozsolics' system by using the same typological method. According to him, the quantity of the artefacts, new types, the spatial distribution and also the fragmentary state of the assemblages are important to determine the stages like the Hoard Find Stage III. ${ }^{203}$ In contrast to him, M. Novotná formulated similar opinion as S. Hansen. She stated that the Gyermely-Type hoards can be determined as a regional combination group in Southwestern Slovakia and Transdanubia and most of these depots can be linked to the Ha B1 stages. Furthermore, the Gyermely hoard itself has a younger dating. ${ }^{204}$ The opinion of P. Turk was also similar when he dated the Slovenian and Western Carpathian "Ha A2 depots" to the Ha B1 stage (Phase III). ${ }^{205}$

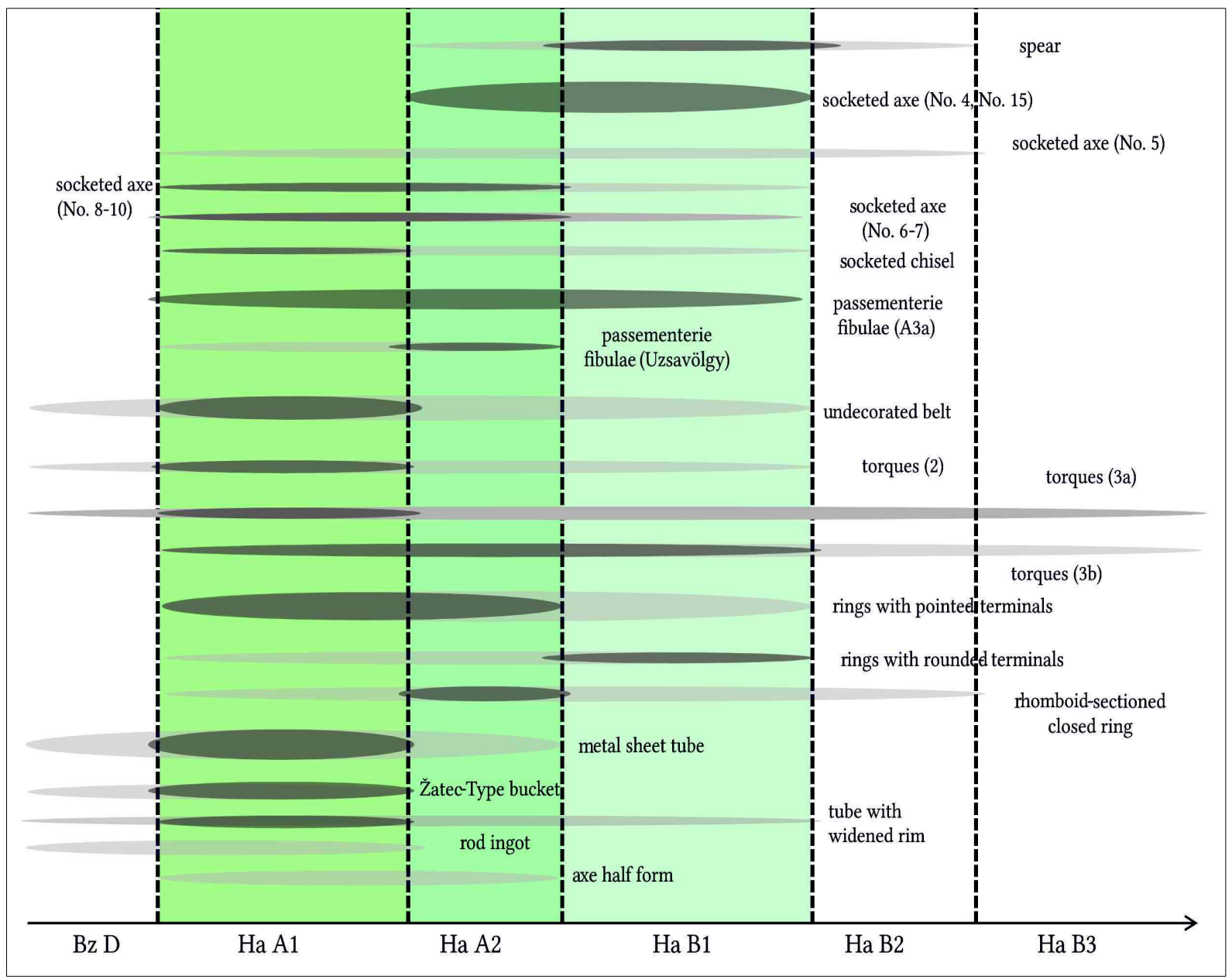

Fig. 42. The relative chronology of the depot's objects. 
Consequently, two different ways of relative dating exist nowadays. According to A. Mozsolics' and T. Kemenczei's chronological scheme the Kesztölc depot can be dated to the Ha A2 stage, but if we take into account the suggestions of the Western research, the analyzed depot can be associated with the Ha B1 stage. However, it is worth to pointing out that this problem is far more complex than a simple modification of the typo-chronology could solve it. From the very beginning of research, our region struggles with two basic problems: 1.) Whereas the metal finds are basically missing from the burials and settlements between the $\mathrm{Br} \mathrm{D}$ and $\mathrm{Ha} \mathrm{B} 2 / 3$ stages, the metal typo-chronology rest on the depot's artefacts. 2.) In most cases the contexts of these hoards are uncertain because they were found by locals, metal detectorists or were donated by collectors (Fig. 43). ${ }^{206}$ To conclude, the main problem with the chronology is the source itself. In contrast to the ceramic typology these assemblages composed of objects from totally different parts of the bygone Bronze Age life. Thereupon, they not just have different function but also different life-circles. ${ }^{207}$ Consequently, their time of use can be very diverse. For instance, a personal object like a sword has been probably use for a long period of time and had a very special life-circle, which could have been effected by different owners and many individual events. Therefore, its various decorations or blade shapes (e. g. leaf or strait blade) which are often described by countless of subtypes rather reflect on the owners' taste, symbolic meanings or fighting styles, and not on short chronological shifts. In connection with this, another problem is that significant part of the hoards - just as the one from Kesztölc - composed objects with different dating or long period of use. Therefore they are basically unsuitable for differentiate short transitional stages like the Ha A2. ${ }^{208}$ No wonder that the different stages, horizons and periods are often overlap of each other. ${ }^{209}$ This problem was seemed to be solved by using of fine typologies of the objects, or making differentiation between the stages by certain features like fragmentation, spatial distribution, combination of artefacts or the appearance of "younger objects and stylistic variants". But against all these attempts the problem basically remained the same. In connection with this, V. Rychner's dendro-chronological analysis should be emphasized. According to his results, the relative chronological stages especially the short "transitional" periods like the Ha A2 are overlapped. ${ }^{210}$ The above analysis clearly proves of the limits of the fine typology in relation to the dating. However, from chronological point of view the main problem is the depots undocumented context. Their composition is uncertain because they are often mixed with older or younger assemblages or individual objects by the finders or previous owners. In addition, some of the artefacts could be lost, kept, sold or even amateurishly modified. In this regard, the depots of the Gyermely horizon are not exceptions. ${ }^{211}$ Consequently, an evident question should be asked: Are these assemblages really suited for determining short chronological stages like the Ha A2? Presently, this question cannot be answered in details. However, the re-evaluation of the previously founded assemblages in the current state of the research and new regional chronologies which are not country related can solve this problem. Although, due to the uncertainty of the source, it is highly possible that S. Hansen's and P. Turk's suggestions are closer to reality, and the relative chronology can only be established on large-scale. 

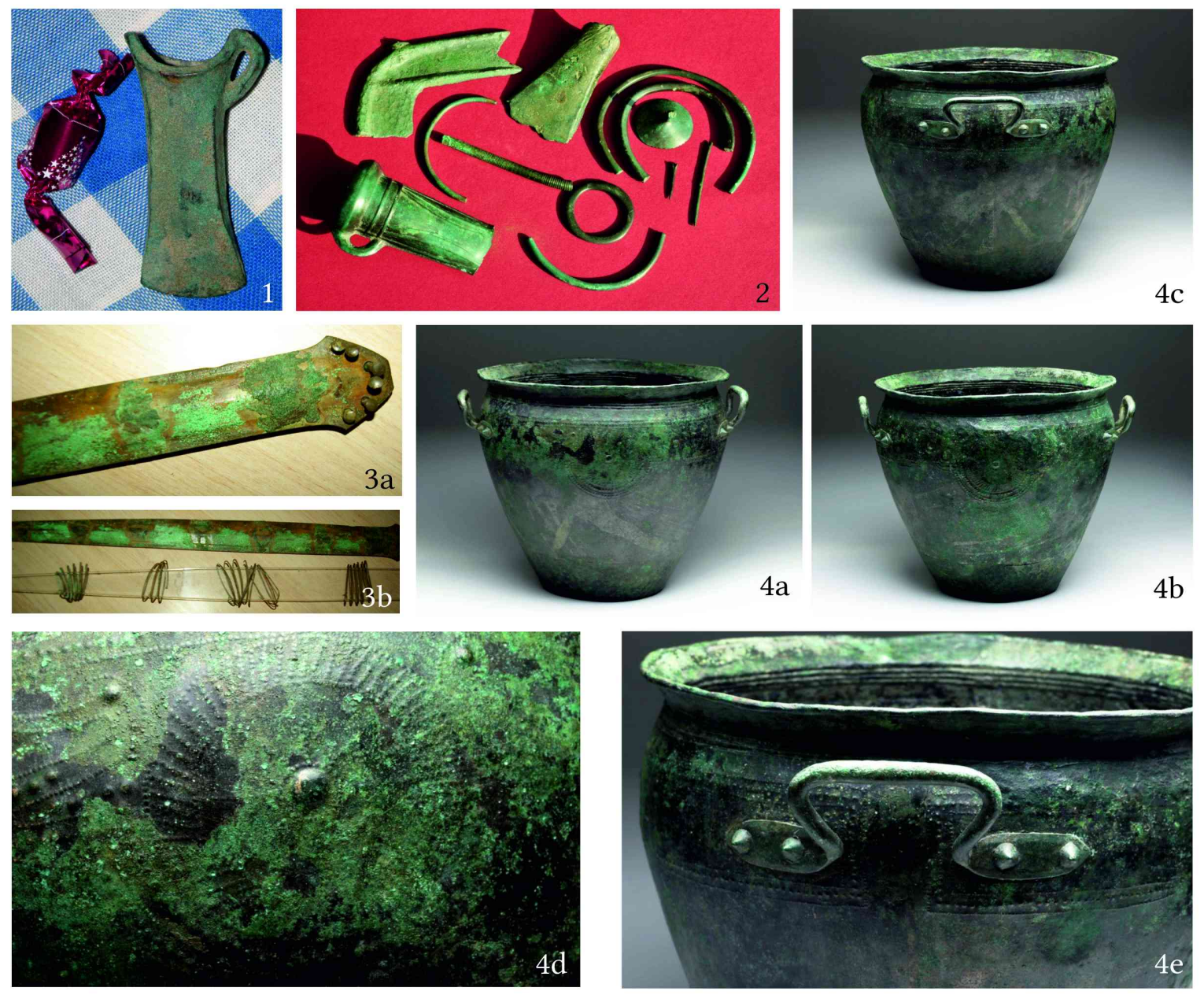

Fig. 43. Individual objects and assemblages from auctions and online marketplaces.

1. "Fémkeresők fóruma": http://femkeresok.europefreeforum.com/post4223.html?style=11\#p4223 (2013.09.01). 2. "Noricum" (uploaded by a Hungarian user): http://www.ebay.com/itm/Ancient-Celtic-Bronze-Axe-Braceletsand-Artefacts-Mix/261 259449 998?_trksid=p2 047 675.m2109\&_trkparms=aid\%3D555 003\%26algo\%3DPW.CAT \%26ao\%3D1\%26asc\%3D17 571\%26meid\%3D977618073657 192 975\%26pid\%3D100 010\%26prg\%3D8140\%26rk \%3D5\%26rkt\%3D15\%26sd\%3D290 $941821491 \% 26$ (2013.09.01).

3a-b: Ebay: http://www.ebay.com/itm/bronze-age-sword-/230896537 187 (2013.09.01).

4a-e: Christie's http://www.liveauctioneers.com/item/30 665 922_superb-hallstadt-bronze-situla (2014.11.05).

Besides the chronological questions, understanding the depot through its objects was another goal of the study. This was partly possible by the analysis of the parallels' spatial distribution and the aid of the macroscopic observations. The Kesztölc depot mainly composed of typical Carpathian objects (e. g. socketed axes, socketed chisel, torques, rings with pointed-terminals ect.) which are not uncommon in Transdanubia (Fig. 11, Fig. 13, Fig. 23, Fig. 26, Fig. 30, Fig. 35, Fig. 40). However, some of them should be underlined by the reason of their spatial distribution. For instance, the A3a passementerie fibula appeared outside of the Carpathian Basin, and reached the territories of the present day Czech Republic and Poland (Fig. 16). Also interesting is the distribution of the Žatec-Type buckets and tubes with widened rims which parallels were unearthed in Western Europe (Fig. 34, Fig. 41). The spatial densification of the undecorated belt should also be emphasized due to the object in question is unique in Transdanubia and might be derived from the northeastern part of the Carpathian Basin (Fig. 20). On the basis of these results it can be concluded that these objects 
were parts of an interaction networks which connected the Carpathian Basin with the Northern and Western parts of Central Europe. It is also worth noting that all of these objects can be determined as special types. The passemeneterie fibula and the belt belong to a high quality, probably very personal jewelry groups. Based on its technique, contexts and combination with other metal vessel types the bucket was likely parts of prestigious drinking sets and if the tube with widened rim was really part of a wagon barrier, there is no need to prove its importance.

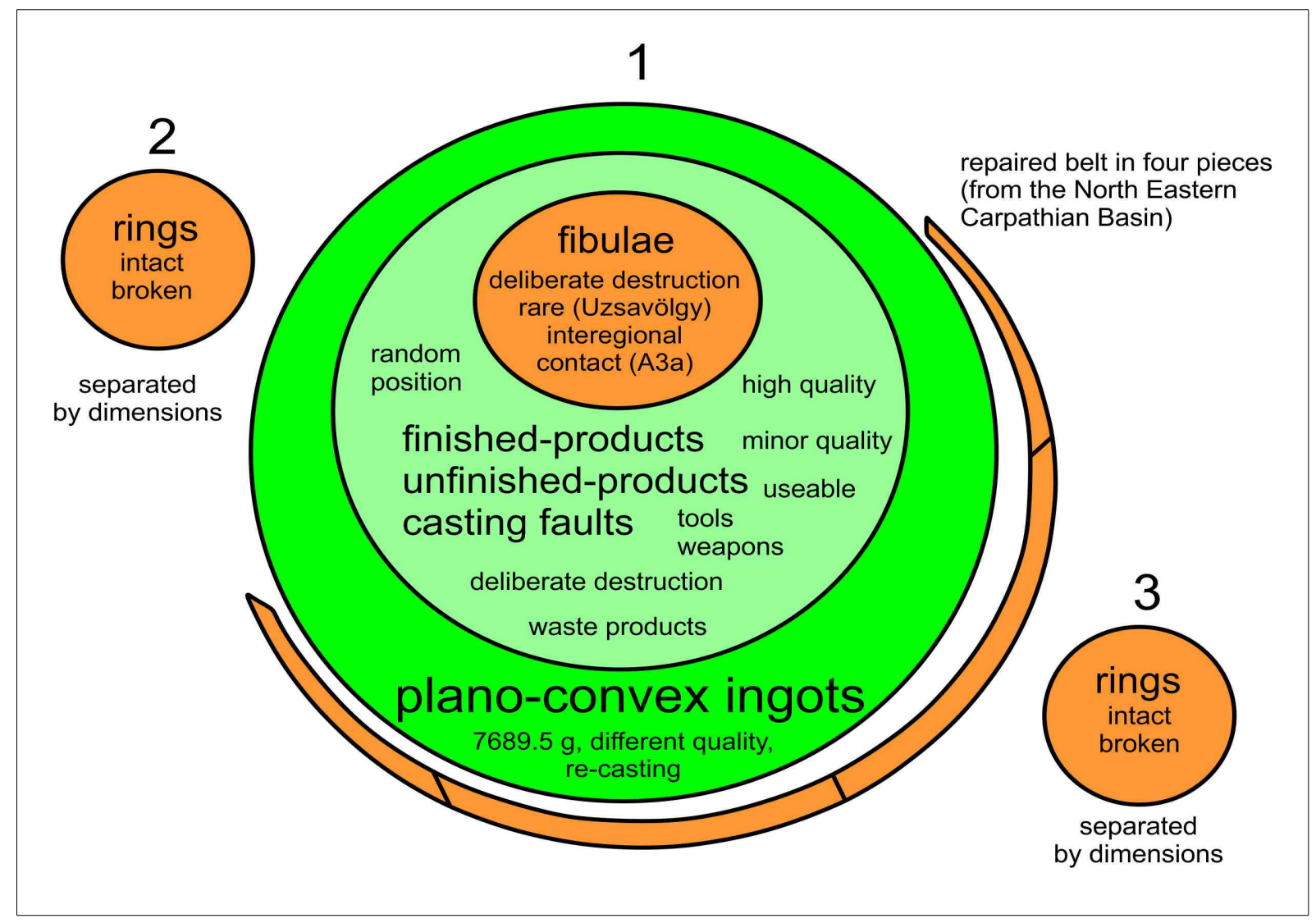

Fig. 44. The reconstruction of the context.

The manufacturing techniques of the analyzed objects are also diverse. Most of them were casted by the bivalve moulds (e. g. spears, socketed axes, chisel), but less common techniques like the lost-wax casting (e. g. ring No. 27, torques No. 24) were also observed among them. The second greatest, however common, technological group is the hammered wire objects such as the rings with pointed-terminals. As we have already noted some artefact such as the fibulae or the metal sheet fragments with ribs-and protrusions can be associated with major manufacturing techniques. Based on the results of the macroscopic observations, the depots objects can be divided into finished, semi-finished, failed-casted and unfinished products. In relation to this, the casted objects were best suited for draw further conclusions. The majority of the socketed axes can be interpreted as unfinished objects (No. 6) or showed clear traces of minor and major casting faults along their outer- and breakage surfaces (No. 4, No. 7-11, No. 14, No. 16). In contrast to them, other artefacts such as the spears (No. 1-3), certain axes (No. 12-13), chisel (No. 18) and the flange-handled sickles (No. 19-20) can be determined as finished products, and they were probably suitable for use before their deposition. 
This is especially true for the chisel which could be used even nowadays. On the contrary, determining the usage of the wire-and metal sheet artefacts is not possible without uncertainties however they were probably also wearable and finished products. The belt is considered to be an exception because clear traces of repairs can be observed on its edge (Fig. 55.23.1). An interesting aspect of the depot is that the prehistoric destruction traces mostly occurred on the useable, finished products. Damage marks and bending is visible on the spears (No. 2-3), and it is possible that some of the socketed axes (No. 12-13) and the sickles (No. 19-20) were also broken by similar manner. Yet again the belt is the most spectacular example which was torn into four parts. ${ }^{212}$ Extreme bending and deliberate breakage can be well-observed among the fibulae, torques and rings as well. Similar phenomenon was described in many parts of Europe, and interpreted as a result of peri-depositional votive, premonetare or profane action. Moreover, some may argue that it could be connected with the funeral rites when the deceases' objects went through different stages of manipulations. ${ }^{213}$

The reconstruction of the depot's context also provided puzzling results. Considering that it shows similar organized placing which was observed among assemblages with documented context. ${ }^{214}$ It was not just buried in three separated parts, but its objects - especially the ones in the central heap - were placed well-designed. The most personal objects - such as the passementerie fibulae and the belt - were positioned in damaged state on special parts of the heap. The less vulnerable artefacts like the plano-convex ingots and socketed utensils were placed on the lower sections (Fig. 44). The location of the depot, a presumably unsettled, wetland area which is separated by a small river from the cemetery, is also remarkable. All these aforementioned topographical features indicate that the depot could be buried in a well-chosen area - probable a liminal zone - within the bygone Bronze Age "mental landscape". ${ }^{215}$ This topographical situation combined with the deliberate destruction of useable fine products and the well-designed deposition is hard to explain by profane motivations. However, we should not fall into the mistake of over-interpretation simply by the reason of the undocumented context, probable high quantity of post-depositional damages and last but not least the radical changes of the area's topography. The final interpretation of the Kesztölc depot requires further, more complex analyzes. Firstly, extensive topographical surveys similarly to the one which was carried out by the case of the Isleham hoard could clarify the exact topographical situation. ${ }^{216}$ Secondly, precise typological and technological comparisons which based on not publication data but the personal re-examination of the parallel finds could provide new results. By the aid of these, I believe that not just the Kesztölc depot but the other hoards from this region could be understood better.

\section{Acknowledgements}

I am grateful to Gábor V. Szabó for the restauration, photography and the possibility of evaluation of the artefacts. I am also indebted to Gergely Radovics who generously contributed to the publication of the depot. For their advices and help, I must thank to Dániel Asztalos, Tiberius Bader, Denisa Lönhardt, Carol Kacsó, István Ecsedy, Csilla Gáti, Gábor Lassányi, Florin Gogâltan, Ferenc Paár, Ildikó Szathmári and Gábor Váczi. I am also indebted to Mónika Fischer for the linguistic revision of the text and to Károly Kozma, photo artist for the photography of the artefacts.

212 It is important to note that according to the finder the belt was found already in four parts.

213 Bradley 1990, 26; Nebelsick 1997, 40-41; 2000, 167-168, 170-171; ReZI 2011, 303-306; SoroceANu 1995, 49; TeRŽAN 1999, 122-123.

214 e. g. Hagl 2008, 5-6, Taf. 2; Mozsolics 1963b, 252, 3. kép; Müller 2006b, 233-235, Abb. 3-4; Patay 1969, 167-168; Soroceanu 205, 35-43; V. Szabó 2011, Taf. 4, Taf. 6-7, Taf. 10.

215 Ballmer 2010a; 2010b; Fontjin 2008, 86-101; Hansen 2008, 291-296; NeumanN 2010, 240-244.

216 MALin ET AL. 2010. 
List 1. Late Bronze Age sites located near to the depot

1. Kesztölc-Bodzás dúlő - depot: TARBAY 2011, 2013.

2. Kesztölc-Cseresznyés hát - cemetery: HoRvÁTH ET AL. 1979, 238.

3. Kesztölc-Sármánka cave - stray ceramic finds: HoRváth ET AL. 1979, 239.

4. Region of Kesztölc - stray ceramic finds: HoRVÁtH ET AL. 1979, 240.

5. Dorog-Dózsa György primary school - stray ceramic finds: HoRvÁtH ET AL. 1979, 61.

6. Dorog-Homoki vineyards - stray ceramic finds: HoRváth ET AL. 1979, 61.

7. Dorog-Kálvária mountain - stray ceramic finds: HoRvÁtH ET AL. 1979, 61.

8. Dorog-Sátorkő sand mine - stray ceramic- and bronze finds: HoRváth ET AL. 1979, 62-63.

9. Territory of Dorog - stray ceramic- and bronze finds: HoRvÁth ET AL. 1979, 64-65.

10. Piliscséve-Tatárszállás - stray ceramic finds: HoRvÁth ET AL. 1979, 280.

11. Piliszentlélek-Legény/Chlapec cave - stray ceramic finds: HoRváth ET AL. 1979, 300-302.

\section{List 2. Spear (No. 1)}

1. Arad 2 (Romania, Arad) - depot: Petrescu-Dîmboviţa 1978, 139, Taf. 223.26.

2. Borsodbóta (Hungary, Borsod-Abaúj-Zemplén) - depot: Kemenczer 1984, 145, Taf. CXVc.3.

3. Dubany (Czech Republic, Prostějov) - depot: Salaš 2005a, 419-420; 2005b, Tab. 341.5.

4. Glod/Glód (Romania, Maramureş) - uncertain depot: Petrescu-Dîmboviţa 1978, 149, Taf. 258C.1.

5. Hida (Romania, Sălaj) - depot: Petrescu-Dîmboviţa 1978, 149, Taf. 260.26.

6. Kapelna (Croatia, Donji Miholjac) - depot: Vinski-Gasparini 1973, 215, Tab. 110.16.

7. Nógrádmarcal (Hungary, Nógrád) - depot: KemencZEi 1984, 150, Taf. CXVIId.13.20.

8. Pétervására (Hungary, Heves) - Collection of Kund: Kemenczei 1984, 119, Taf. LIIb.2.

9. Săcuieni/Székelyhíd (Romania, Bihor) - depot: Petrescu-Dîmbovița 1978, 144, Taf. 238B.18.

10. Tešanj/Stanari 2 (Bosnia and Hercegovina, Teslić) - depot: KöNIG 2004, 223-224, Taf. 32.1.

\section{List 3. Socketed axes (No. 4) with with ribbed decoration}

1. Beravci (Croatia, Vrpolje) - depot: VINSKI-GASPARINI 1973, 211, Tab. 108.3.4.8.

2. Beremend (Hungary, Baranya) - depot: Mozsolics 1985, Taf. 253.2.

3. Biatorbágy-Herceghalom (Hungary, Pest) - depot: HAMPEL 1896, CCIX. tábla 2.

4. Bokavić (Bosnia and Hercegovina, Lukavac) - depot: KöNIG 2004, 184-191, Taf. 38.27.

5. Brvnište/Boronás (Slovakia, Považská Bystrica) - depot: Novotná 1970a, 91-92, Taf. XLVII.

6. Cornești/Magyarszarvaskend (Romania, Mureș) - depot: Petrescu-Dîmbovița 1978, 141-142, Taf. 229.11.

7. Cluj-Napoca/Kolozsvár 2 (Romania, Cluj) - depot: Petrescu-Dîmboviţa 1978, 141, Taf. 228B.6.

8. Debrecen 3 (Hungary, Hajdú-Bihar) - depot: Mozsolics 1985, 110-111, Taf. 265.2.

9. Detva/Gyetva (Slovakia, Zvolen) - depot: NovotnÁ 1970b, 84, Taf. 34.601.

10. Dîrja (Romania, Cluj) - depot: Petrescu-Dîmbovița 1978, 138, Taf. 219.19.

11. Donja Koričani (Bosnia and Hercegovina, Jajce) - stray find: GAVRANović 2011, 139, Abb. 139.1.

12. Jászkarajenő (Hungary Pest) - depot: Mozsolics 1985, 129-130, Taf. 250.18.

13. Jevičko (Czech Republic, Svitavy) - depot: SALAš 2005a, 346-348; 2005b, Tab. 177C.1-2.

14. Jupalnic (Romania, Mehedinţi) - depot: Petrescu-Dîmbovița 1978, 138, Taf. 220B.2.

15. Kapelna (Croatia, Donji Miholjac) - depot: Vinski-Gasparini 1973, 215, Tab. 110.15.

16. Kostolec i Holešová (Czech Republic, Kroměříž) - stray find: ŘínovskÝ 1992, 205, Taf. 50.736.

17. Liborajdea/Liborásdia (Romania, Banat) - depot: Gumă - Dragomir 1985, 111, Fig. 2.3. Fig. 3.2.

18. Lovasberény (Hungary, Fejér) - depot: Mozsolics 1985, 144-145, Taf. 244.2-4.6.8.13.

19. Lukavac Crkvište (Bosnia and Hercegovina, Tuzla) - depot: ŽERAviCna 1993, 94, Taf. 36.478.

20. Malaja Dobron'/Mala Dobron' (Ukraine, Užgorod) - depot: KoвAL' 2000, 86, Taf. 75A.13.

21. Monj (Bosnia and Hercegovina, Gračanica) - depot: KöNIG 2004, 209-211, Taf. 51.2.

22. Mukačevo/Mukačeve/Munkács 2 (Ukraine, Mukačevo) - depot: KoвAL' 2000, 88, Taf. 77C.1.

23. Nagydobsza (Hungary, Baranya) - depot: TARBAy 2013, 214, 433-434, 4. Tábla 7.

24. Nagykálló 1 (Hungary, Szabolcs-Szatmár-Bereg) - depot: Mozsolics 2000, 59, Taf. 61.5.

25. Napkor (Hungary, Szabolcs-Szatmár-Bereg) - depot: Mozsolics 1985, 157-158, Taf. 257.4-8.

26. Oberstdorf bei Allgäu (Germany, Bavaria) - stray find: PÁszthoRy - MAYER 1998, 145, Taf. 70.1045.

27. Pap 3 (Hungary, Szabolcs-Szatmár-Bereg) - depot: Mozsolics 2000, 65, Taf. 72.10.

28. Pietrosu/Pietrosz/Nagy-Köves (Romania, Buzău) - depot: Petrescu-Dîmboviţa 1978, 147, Taf. 251C.2.

29. Porta Bohemica-Labe (Czech Republic, Litoměřice) - depot: Kytuicová 2007, 292-293, Taf. 127.65-67.

30. Somotor/Szomotor A (Slovakia, Trebišov) - depot: Novotná 1970a, 118, Taf. XLVI.13.

31. Salzburg (Austria) - uncertain stray find: MAYER 1977, 193, Taf. 77.1062.

32. Siče (Croatia, Nova Kapela) - depot: VINSKI-GASPARINI 1973, 218, Tab. 95.2-3. 
33. Slavonski Brod (Croatia, Slavonski Brod) - depot: VINSKI-GASPARINI 1973, 219, Tab. 106.7. 34. Služín (Czech Republic, Prostějov) - depot: SAlaš 2005a, 452; 2005b, Tab. 421.4, Tab. 422.7. 35. Suskovo/Suskovo/Szuszkó 1 (Ukraine, Svaljava) - depot: KoBAL' 2000, 95-96, Taf. 74.13. 36. Srpska Varoš (Bosnia and Hercegovina, Tešanj) - depot: KöNIG 2004, 219, Taf. 50B.1. 37. Székesfehérvár (Hungary, Fejér) - depot: Mozsolics 1985, 191-192, Taf. 243.2-3.

38. Slovakia - unkown: Novotná 1970b, 83, Taf. 33.593.

39. Tiszavasvári (Hungary, Szabolcs-Szatmár-Bereg) - depot: Mozsolics 1985, 205, Taf. 261.2-3.

40. Velem 1 (Hungary, Vas) - depot: Mozsolics 1985, 211-213, Taf. 230A.8.14.

41. Velikaja Began’ or Zmeevka (Ukraine, Beregovo) - depot: KoBAL’ 2000, 98, Taf. 90B.2.

42. Vésztő (Hungary, Békés) - depot: Mozsolics 2000, 90-91, Taf. 116.11.

43. Zagon/Zágon 2 (Romania, Covasna) - depot: Petrescu-DîmboviţA 1978, 147, Taf. 250B.4, Taf. 251A.8.

44. Zsáka-Dávid tanya 1 (Hungary, Hajdú-Bihar) - depot: V. SzABó 2011, Taf. 8.2-3.

\section{List 4. Socketed axes (No. 5)}

1. Dunavecse (Hungary, Pest) - depot: Mozsolics 2000, 42, Taf. 26.3.

2. Middle-Europe - London Coin Gallerie: http://www.londoncoin.com/antiquities/ancientgreece/1489/bronze-axe-head/ (2012.10.31).

3. Uioara de Sus/Felsőmarosújvár (Romania, Alba) - depot: Petrescu-DîmboviţA 1978, Taf. 164.95.

4. Püspökhatvan (Hungary, Pest) - depot: Mozsolics 1985, 178-179, Taf. 139.15.

5. Slavonski Brod (Croatia, Slavonski Brod) - depot: VINSKI-GASPARINI 1973, 219, Tab. 106.5.

6. Zsáka-Dávid-tanya 1 (Hungary, Hajú-Bihar) - depot: V. SzABó 2011, Taf. 8.3.

List 5. Undecorated socketed axes (No. 6-7)

7. Brodski Varoš (Croatia, Slavonski Brod) - depot: Vinski-GASPARINi 1973, 212, Tab. 60.1-2.

8. Hajdúsámson 4 (Hungary, Hajdú-Bihar) - depot: Mozsolics 2000, 48-49, Taf. 38.1.

9. Hódmezővásárhely (Hungary, Csongrád) - depot: Mozsolics 1985, 128, Taf. 255.24.

10. Nadap (Hungary, Fejér) - depot: Makkay 2006, 13. tábla 109.

11. Nagydobsza (Hungary, Baranya) - depot: TARBAY 2013, 214, 497, 5. tábla 8.

12. Szentes-Nagyhegy 1 (Hungary, Csongrád) - depot: KemenCzei 1984, 417, Taf. CCVIIc.2.

13. Várvölgy-Nagyláz-hegy (Hungary, Zala) - depot: Müller 2006a, 7. kép.

14. Văratic 2 (Moldova, Rîşcani) - depot: DergačEv 2002, 46-47, Taf. 49.5.

15. Vésztő (Hungary, Békés) - depot: Mozsolics 2000, 90-91, Taf. 116.5.

List 6. Undecorated socketed axes (No. 8 - 10) with curve body

16. Bizovac (Croatia, Osijek) - depot: VINSKI-GASPARINI 1973, 212, Tab. 37.11.

9. Hódmezővásárhely (Hungary, Csongrád) - depot: Mozsolics 1985, 128, Taf. 255.4.

17. Jászkarajenő (Hungary, Pest) - depot: Mozsolics 1985, 129-130, Taf. 251.14.

11. Nagydobsza (Hungary, Baranya) - depot: TARBAY 2013, 215, 497, 6. tábla 9.

12. Szentes-Nagyhegy 1 (Hungary, Csongrád) - depot: Mozsolics 2000, 76-77, Taf. 92.1.4-5.8.

\section{List 7. Socketed chisels}

1. Dubany (Czech Republic, Prostějov) - depot: Salaš 2005a, 419-420; 2005b, Tab. 341.4.

2. Lengyeltóti 2 (Hungary, Somogy) - depot: Mozsolics 1985, 142-143, Taf. 107.2.

3. Lengyeltóti 4 (Hungary, Somogy) - depot: Mozsolics 1985, 143-144, Taf. 110.2.

4. Trenčianske Bohuslavice/Bogoszló (Slovakia, Trenčín) - depot: NovotnÁ 1970a, Taf. XIV.

5. Várvölgy-Nagy-Lázhegy (Hungary, Zala) - depot: MülLER 2011, 218, 1. ábra 2-5, 2. ábra 9, 5. ábra, 7. ábra 32.

\section{List 8. Passamenterie fibulae type $A 3 a^{217}$}

1. Balatonkiliti (Hungary, Somogy) - depot: Kuzsınszky 1920, 4-8, 6. ábra 7.

2. Bokod (Hungary, Komárom-Esztergom) - depot: Patay 1964, 2. ábra 1.

3. Bölcske (Hungary, Tolna) - stray find: GAÁL 2001, 41-50, Abb. 2.1-3.

4. Brodski Varoš (Croatia, Slavonski Brod) - depot: Vinski-GASPARINI 1973, 212, Taf. 52.9-22.

5. Celldömölk-Sághegy (Hungary, Vas) - grave: KőszEGI 1988, 130, 47. tábla.

6. Corneşti/Sinfalva (Romania, Cluj) - depot: Nestor 1932, 137, Abb. 30.1.

7. Érsekvadkert (Hungary, Nógrád) - depot: Kemenczei 1984, 147.

217 Based on the results of Gábor Váczi's recent study, the one from Sióagárd cannot be sorted into the A3a type. Holste 1951, 22-23, Taf. 43.35-36; TARBAy 2012, VI. lista 67; VÁcZi 2014, 47, 2. kép 43. 
8. Gyermely-Szomor (Hungary, Komárom-Esztergom) - depot: VÁsÁRHELYi 1889, 62, 1. tábla 1-2.

9. Dunaújváros (Hungary, Fejér) - stray find: TARBAY 2012, 116, 4. kép.

10. Kammený Most/Kőhídgyarmat (Slovakia, Nové Zámky) - depot: Novotná 2001, 39, Taf. 6.62.

11. Kenderes 2 (Hungary, Jász-Nagykun-Szolnok) - depot: HAMPEL 1892, 63, CLVIII. tábla 21.

12. Orci (Hungary, Somogy) - depot or grave: UNDSET 1884, 200-208, I. tábla 8.

13. Sînpetru German/Németszentpéter (Romania, Arad) - depot: BADER 1983, 44, Taf. 6.27-29.

14. Simonfa (Hungary, Somogy) - depot: Mozsolics 1985, 185.

15. Świerczów/Tschwirtschen (Poland, Niechlów) - stray find: GEDL 2004a, 79-80, Taf. 52.220.

16. Szécsény/Benczúrfalva/Dol'any 2 (Hungary, Nógrád) - depot: HAMPEL 1877, Pl. XVI.9.

17. Pawłowice Namysłowskie/Paulsdorf (Poland, Namsłów) - depot: GedL 2004a, 79, Taf. 52.219.

18. Porta-Bohemica-Labe (Czech Republic, Litoměřice) - depot: Kytlicová 2007, 292-293, Taf. 119.4.

19. Rimavská Sobota/Rimaszombat (Slovakia, Banská Bystrica) - depot: NovotnÁ 2001, 39, Taf. 6.60, Taf. 6.63.

20. region of Trenčín/Trencsény (Slovakia, Trenčín) - stray find: NovotnÁ 2001, 39, Taf. 6.62.

21. Velem 1 (Hungary, Vas) - depot: HAMPEL 1896, CCXLI. Tábla 2.3.

22. Middle Europe - Ward\&Company: length: 17,5 cm : http:/www.wardco.net/objects/bronze/posamenterie-fibula; (2011.10.13 19:47)

23. Unknown - Hermann Historica: http://www.hermann-historica.de/auktion/hhm67.pl?db=kat67_a.txt\&f$=$ ZAEHLER\&c $=287 \& \mathrm{t}=$ temartic_A_GB\&co $=6$

\section{List 9. Passementerie fibulae type Uzsavölgy (Group C)}

24. Badacsonytomaj-Köbölkút (Hungary, Veszprém) - depot: Mozsolics 1949, 26-29, Taf. 22.1.

25. Kurd (Hungary, Tolna) - depot: HAMPEL 1895, Taf. IV.3-40.

26. Lengyeltóti 2 (Hungary, Somogy) - depot: WANZEK 1992, 259-260, Taf. 10.7.9, Taf. 21.22.

27. Lesenceistvánd/Uzsavölgy 2 (Hungary, Veszprém) - depot: Szentmártoni DARnAy 1910, 426-431, I. Tábla 1.

28. Kuzmin (Serbia, Srem, Šid) - depot: VAsıć 1999, 24, Taf. 4.49.

29. Unknown - Hermann Historica: length: $21.8 \mathrm{~cm}$ : http://www.hermann-historica.de/auktion/hhm67.pl? $\mathrm{f}=\mathrm{NR} \_L O T \& \mathrm{c}=2286 \& \mathrm{t}=$ temartic_A_GB\&db=kat67_a.txt(2014.11.05).

List 10. Belts in the Late Bronze Age Carpathian Basin and its neighbourhood regions

List 10.1. Riegsee-Type belts

1. Blučina 8 (Czech Republic, Brno) - depot: Řínovskí 1982, Tab. 59.22.

2. Drslavice 1 (Czech Republic, Uherské Hradiště) - depot: Kilian-Dirlmeier 1975, 105, Taf. 42.418.

3. Haag 15 (Germany, Bavaria) - tumulus grave: Kilian-DirlmeIER 1975, 106, Taf. 43.427.

4. Lažanay 3 (Czech Republic, Chotmutov) - depot: Kytuicová 2007, 275-276, Taf. 77b.14.

5. Lengyeltóti 2 (Hungary, Somogy) - depot: Kilian-Dirlmeier 1975, 106, Taf. 43.423.

6. Leombach (Austria, Lower Austria) - depot: HöGlinger 1991, 36, Abb. 9A.

7. Levoča/Lőcse (Slovakia, Spiš) - stray find: FurmANeK ET AL. 1999, 176, Taf. 29 b.

8. Uffing 1 (Germany, Bavaria) - tumulus grave: NAUE 1887, 53-54, Taf. 18.3.

9. Uffing 3 (Germany, Bavaria) - tumulus grave: NAUE 1887, 53-54, Taf. 18.14.

10. Riegerau 6 (Germany, Bavaria) - tumulus grave: Kilian-DirLmeIER 1975, 106, Taf. 43.426.

11. Riegsee 8 (Germany, Bavaria) - tumulus grave: Kilian-Dirlmeier 1975, 105, Taf. 42.414.

12. Riegsee 25 (Germany, Bavaria) - tumulus grave: Kilian-Dirlmeier 1975, 105, Taf. 42.420.

13. Riegsee 34 (Germany, Bavaria) - tumulus grave: Kilian-Dirlmeier 1975, 104, Taf. 42.421.

14. Spiš/Zips/Szepes (Slovakia, Spiš) - stray find: Kilian-DirlmeIER 1975, 105, Taf. 42.417.

15. Velvary (Czech Republic, Kladno) - depot: Kytuicová 2007, 313-314, Taf. 54.18.

16. Volders 60 (Austria, Tirol) - grave: Kilian-Dirlmeier 1975, 105-106, Taf. 42.419.

17. Volders 229 (Austria, Tirol) - grave: Kilian-Dirlmeier 1975, 105-106, Taf. 43.422.

18. Volders 321 (Austria, Tirol) - grave: Kilian-Dirlmeier 1975, 105-106, Taf. 43.425.

19. Westendorf (Austria, Tirol) - grave: WAGNER 1943, 119, Taf. 26.2-5.

List 10.2. Belts with punched decoration

1. Aiud/Nagyenyed (Romania, Alba) - depot: Petrescu-Dîmboviţ̧a 1977, 80-81, Pl. 108.

2. Aggtelek (Hungary, Borsod-Abaúj-Zemplén) depot: Kemenczer 1984, 127-128, Taf. C.14.

3. Apagy (Hungary, Szabolcs-Szatmár-Bereg) - depot: JósA - Kemenczer 1963-1964, 1. tábla 5.

4. Band/Mezőbánd (Romania, Mureş) - depot: Petrescu-Dîmboviţa 1978, 113-114, Taf. 80.22-23.

5. Baniabic/Vîlcele/Bányabükk (Romania, Cluj) - depot: SoroceAnu 1981, Abb. 1.4.

6. Caransebeş/Karánsebes (Romania, Caraş-Severin) - depot: Holste 1951, Taf. 18.5-6. 
7. Dipsa/Dipse (Romania, Bistriţa-Năsăud) - depot: CiUgudEAn ET AL. 2006, Pl. XXXV.1.

8. Dolny Sukolom (Czech Republic, Uničov) - depot: TrŇÁčKová 1965, Abb. 3.8

9. Dumeşti (Romania, Huneoadara) - depot: Petrescu-Dîmboviţa 1978, 119, Taf. 99B.8.

10. Drslavice 1 (Czech Republic, Uherské Hradišté) - depot: ŠAlas 2005a, 317-332; 2005b, Tab. 131.428, Tab. 135.585-589, Tab. 136.584-596, Tab. 137.590-591.597-599.601, Tab. 138.602.

11. Drslavice 2 (Czech Republic, Uherské Hradišté) - depot: ŠAlas 2005a, 332-342; 2005b, Tab. 164.268, Tab. 165.275 .

12. Ebergőc (Hungary, Győr-Moson-Sopron) - depot: BÁNDi 1962, 2. kép 13.

13. Elsterweda (Germany, Brandenburg) - depot: vON BRUNN 1968, 317, Taf. 62.55-56.

14. Esztergom (Hungary, Komárom-Esztergom) - depot: Mozsolics 1985, 116-118, Taf. 137.6-9.

15. Felsődobsza (Hungary, Borsod-Abaúj-Zemplén) - depot: Mozsolics 1973, 134-135, Taf. 47.33.

16. Fizeşul/Füzes (Romania, Cluj) - depot: SoroceAnu 1995, 48, Abb. 14.2.

17. Futtak/Futog (Serbia, Vojvodina) - depot: Hansen 1994, 563; Kilian-Dirlmeier 1975, 110.

18. Giula/Gyula (Romania, Cluj) - depot: Petrescu-Dîmboviţa 1977, 95, Pl. 147.6.7.

19. Guşteriţa/Szenterzsébet/Hammersdorf 2 (Romania, Sibiu) - depot: Petrescu-Dîmboviţa 1978, Taf. 117.323-328.

20. Gruszka (Poland, Kielce) - depot: Kilian-Dirlmeier 1975, 110.

21. Kaliny/Felső-Kalinfalva (Ukraine, Tiachiv) - depot: BERNJAKOvič 1960, 355.

22. Kamýk nad Vlatavou (Czech Republic, Příbram) - depot: Kytlicová 2007, 268-269, Taf. 25.10-13.

23. Klenje (Serbia, Bogatić) - depot: Јацановић 1986, 171, Taf. 13.

24. Hungary - stray find: Kilian-Dirlmeier 1975, 109, Taf. 46.455.

25. Márok (Hungary, Baranya) - depot: Mozsolics 1985, 146, Taf. 92.36.

26. Medvedevcy/Medvegyive 1 (Ukraine, Munkačevo) - depot: BALAHURi 1966-1967, 80-81, 1. tábla 4.6.7.12.

27. Mişid/Méhsed (Romania, Bihor) - depot: HANSEN 1994, 607.

28. Mušov 2 (Czech Republic, Břeclav) - depot: SAlaš 2005a, 357-371; 2005b, Tab. 200.8, Tab. 217.232-233, Tab. 218.261-262.

29. Novi Bečej/Törökbecse/Újbecse (Serbia, Zrenjanin) - depot: Haち 1955, Taf. 6.

30. Nyírbogdány (Hungary, Szabolcs-Szatmár-Bereg) - depot: Kilian-Dirlmeier 1975, 109, Taf. 47.447.

31. Uioara de Sus/Felsőmarosújvár (Romania, Alba) - depot: Holste 1951, Taf. 44.1-6.

32. Palotabozsok (Hungary, Vas) - depot: Kilian-Dirlmeier 1975, 110, Taf. 46.454.

33. Pecica/Pécska 2 (Romania, Arad) - depot: Kemenczei 1991, 2. ábra 1, 3. ábra 1.

34. Pečinci (Serbia, Stremska Mitrovica) - depot: Милошевин 1960, 156, Taf. 13.8-10.

35. Polesoviče (Czech Repulic, Uherské Hradiště): ŠAlas 1997, 42, Taf. 24.608-612b, Taf. 25.615-620.

36. Răbagani/Robogány (Romania, Bihor) - depot: Petrescu-DîmboviţA 1978, 125, Taf. 131B.22-23.

37. Sântana/Sîntana/Újszentanna (Romania, Mureş) - individual find: PAul 1994, 137, Abb. 36.

38. Sântana (Romania, Mureş) - individual find: GogÂltan - SAVA 2010, Fig. 14.

39. Slavonski Brod (Croatia, Slavonski Brod) - depot: Clausing 2003, Abb. 73.37-38.

40. Suseni/Marosfelfalu (Romania, Mureş) - depot: Petrescu-Dîmboviţa 1978, 127, Taf. 138.71-77.

41. Spălnaca/Ispánlaka 2 (Romania, Alba) - depot: Petrescu-Dîmboviţa 1978, 127-131, Taf. 152.439-447, Taf. 153.448-482.

42. Tăut/Körösfeketetót (Romania, Bihor) - depot: Mozsolics 1973, Taf. 48.13a-b.

43. Vajdácska (Hungary, Borsod-Abaúj-Zemplén) - depot: Kemenczei 1982, 153, 167-157, Abb. 1.1.2, Taf. 5, Taf. 6.

List 10.3. Undecorated belts

1. Banka (Slovakia, Trnava) - depot: NovotnÁ 1980, 30-31, Taf. 65A.6-7.

2. Cehălut/Magyarcsaholy 1 (Romania, Satu Mare) - depot: Petrescu-Dîmboviţa 1978, 99, Taf. 25.35-36.

3. Cubulcut/Köbölkút (Romania, Bihor) - depot: Petrescu-Dîmboviţa 1978, 118, Taf. 92B.12.

4. Debrecen 2 (Hungary, Hajdú-Bihar) - depot: Kilian-Dirlmeier 1975, 116, Taf. 52/53.479.

5. Drslavice 1 (Czech Republic, Uherské Hradišté) - depot: Kilian-Dirlmeier 1975, 116, Taf. 53.481.

6. Jarak 1 (Croatia, Stremska Mitrovica) - depot: VINSKI-GASPARINI 1973, 214-215, Taf. 83.17.

7. Jurka vas (Slovenia, Straža) - depot: ČERČE - ŠINKovec 1995, 198-203, Tab. 91.44.

8. Kék-Sátoroshegy (Hungary, Szabolcs-Szatmár-Bereg) - depot: Kilian-DirLmEIER 1975, 115, Taf. 48/49.474.

9. Lhotka Liblinská (Czech Republic, Rokycany) - depot: Kytlicová 2007, 276-277, Taf. 16.75.

10. Makar'evo/Makar'ovo (Ukraine, Munkačevo) - depot: KoBAL' 2000, 85, Taf. 65.10.

11. Mérk-Kertalja (Hungary, Szabolcs-Szatmár-Bereg) - depot: SőREgi 1930, 73, Abb. 5.9-11.

12. Mĕrovice (Czech Republic, Přerov) - depot: ŠAlAs 2005a, 403-405; 2005b, Tab. 299A.12.

13. Otok-Privlaka (Croatia, Vinkovci) - depot: VinSKI-GASPARINI 1973, 217, Tab. 29.21-22.

14. Užgorod/Ungvár (Ukraine, Užgorod) - depot: BERnJAKovič 1960, 373, Taf. XVII.4.

15. Şuncuiuş/Vársonkolyos (Romania, Bihor) - depot: DumitrașCU - CRIȘAN 1989, Pl. IV, Pl. XXIIa; Pl. XXII.1. 
16. Şpălnaca/Ispánlaka 2 (Romania, Alba) - depot: Petrescu-DîmboviţA 1977, 108-110, Pl. 203.7-8.

17. Szabolcsbáka/Nagybáka (Hungary, Szabolcs-Szatmár-Bereg) - depot: Kilian-Dirlmeier 1975, 115, Taf. 50/51.473.

18. Tállya (Hungary, Borsod-Abaúj-Zemplén) - depot: KemenCZEI 1984, 185-186, Taf. CLXXXVIII.11-13.

List 10.4. Unclassifiable sheet belts

1. Bogdan Vodă/Izakonyha (Romania, Maramureş) - depot: MotzoI-ChicideAnu - IUgA 1995, 154, Abb. 7.9-14.16-18.

2. Hočko Pohorje (Slovenia, Hoče-Slivnica) - depot: ČERČE - ŠInKovec 1995, 177-195, Pl. 80.124.

3. Ordaea/Großwardein/Nagyvárad (Romania, Bihor) - depot: KAcsó 1995, Abb. 5.17.

\section{List 11. Torques with rolled terminals}

List 11.1. 1.) Undecorated torques with rolled terminals

1. region of Bonyhád (Hungary, Tolna) - depot: Mozsolics 1985, 102-104, Taf. 39.28-31.

2. Dridu (Romania, Ialomiţa) - depot: EnĂCHIUC 1995, Abb. 4.3.

3. Drslavice 2 (Czech Republic, Uherské Hradiště) - depot: SALAš 2005a, 332-342; 2005b, Tab. 165.295.

4. Gemer/Sajógömör (Slovakia, Gemer) - depot: HAMPEL 1886b, V. tábla 21.

5. Gyöngyössolymos-Kishegy 4 (Hungary, Heves) - depot: Kemenczei 1980, V. tábla 32.

6. Haidin/Hajdina (Slovenia, Ptuj) - cemetery: Müller-KarPe 1959a, 272; 1959b, Taf. 116.27.

7. Jobaháza (Hungary, Győr-Moson-Sopron) - depot: Mozsolics 2000, 50, Taf. 41.5.

8. Józsa (Hungary, Hajdú-Bihar) - depot: KemenCZEi 1984, 173, Taf. CLXXXc.3.

9. Kamena Gorica (Croatia, Varažin) - depot: VInSKI-GASPARINI 1973, 215, Tab. 126B.14.

10. Kecel (Hungary, Bács-Kiskun) - private collection: Mozsolics 2000, 52-53, Taf. 47.12.

11. Lengyeltóti 2 (Hungary, Somogy) - depot: Mozsolics 1985, 142-143, Taf. 107.8.29-30.

12. Lengyeltóti 3 (Hungary, Somogy) - depot: Mozsolics 1985, 142-143, Taf. 109.4.6-8.

13. Markovac-Grunjac (Serbia, Banat) - depot: JovANović 2010, Tab. 53.467.

14. Monj (Bosnia and Hercegovina, Gračanica) - depot: KöNIg 2004, 209-211, Taf. 51.6.

15. Nadap (Hungary, Fejér) - depot: MAкKay 2006, XXIV. tábla 213-214, XXV. tábla 247.

16. Nagyhalász-Pálhalom-dűlő (Hungary, Szabolcs-Szatmár-Bereg) - depot: KemenczeI 1984, 177, Taf. CLXXIV.15.

17. Öreglak (Hungary, Somogy) - depot: Mozsolics 1985, 163-165, Taf. 84.9.12.

18. Uioara de Sus/Felsőmarosújvár (Romania, Alba) - depot: Petrescu-Dîmboviţa 1978, 132-135, Taf. 201.1099-1100.1097.

19. Přestavlky (Czech Republic, Přerov) - depot: Salaš 2005a, 380-387; 2005b, Tab. 260.80.

20. Slavonski Brod (Croatia, Slavonski Brod) - depot: Clausing 2003, Abb. 36.112a.

21. Szárazd 1 (Hungary, Tolna) - depot: Mozsolics 1985, 188-189, Taf. 28.7.

22. Szentgáloskér (Hungary, Somogy) - depot: Mozsolics 1985, 194-195, Taf. 112.12-13.

23. Szombathely-Zanat (Hungary, Vas) - grave 31: Ilon 2011, 171, 33. ábra 3, 81. ábra 4.

24. Velika Gorica (Croatia, Zagreb) - cemetery F/1910: Karavanić 2009, 69, Pl. 58.1.

25. Zabar (Hungary, Nógrád) - depot: PAulík 1965, 70, Tab. IX.2.

Variant with greater size

26. Hočko Pohorje (Slovenia, Hoče-Slivnica) - depot: ČERČE - ŠInKovEc 1995, 177-195, Pl. 75.89.

List 11.2. 2.) Torques with rolled ends and lost-wax casted motifs

1. Baradac-Rukumija (Serbia, Požarevac) - depot: VAsıć 2010, 23, Taf. 11.78.

2. Belgrad-Autokomanda (Serbia, Belgrad) - depot: VAsIć 2010, 22, Taf. 11.74.

3. region of Belgrád (Serbia, Belgrad) - depot: VAsIć 2010, 22, Taf. 11.75.

4. Biatorbágy-Herceghalom (Hungary, Pest) - depot: Mozsolics 1985, 127-128, Taf. 238.1.

5. Bingula-Divoš (Croatia, Stremska Mitrovica) - depot: VINSKI-GASPARINI 1973, 211, Tab. 86.27-28.

6. Chotín/Hetény 2 (Slovakia, Komárno) - cemetery: Novotná 1984, 32, Taf. 40.259.

7. Dobrinci (Serbia, Pećinci) - depot: VAsić 2010, 23, Taf. 12.81-85.

8. Donji Petrovci 2 (Serbia, Pećinci) - depot: VAsić 2010, 23, Taf. 12.86-87.

9. Dridu (Romania, Ialomița) - depot: ENĂCHIUC 1995, Abb. 4.7-10.

10. Kanalski Vrh 1 (Slovenia, Littoral) - depot: ČERČE - ŠINKOvEC 1995, 203, Pl. 97.10, Pl. 98.11-12, Pl. 99.14-17.

11. Kék (Hungary, Szabolcs-Szatmár-Bereg) - depot: Mozsolics 1985, 131-132, Taf. 192.12.

12. Keszthely-Apátdomb (Hungary, Zala) - settlement: SÁGi 1909, 7. kép 8. 
13. Klinci (Serbia, Valjevo) - grave: VASIĆ 2010, 24, Taf. 14.100.

14. Krčedin 1 (Serbia, Indjija) - depot: VAsIĆ 2010, 24, Taf. 14.101.

15. Nadap (Hungary, Fejér) - depot: MAKkay 2006, Pl. XXV. 241.215.

16. Novi Bečej/Törökbecse/Újbecse (Serbia, Banat) - depot: VAsić 2010, 25, Taf. 15.108.

17. Uioara de Sus/Felőmarosújvár (Romania, Alba) - depot: Petrescu-Dîmboviţa 1978, 132-135, Taf. 201.111.

18. Ugrinovci (Serbia, Indjija) - depot: VAsıć 2010, 26, Taf. 16.114-115.

19. region of Ung 3 (Ukraine, Ung) - depot: KoвAL' 2000, 101, Taf. 78B.1-2.

20. Pančevo-Gornjovaroška ciglana (Serbia, Banat) - depot: VAsIć 2010, 25, Taf. 15.109.

21. Poljanci (Croatia, Slavonski Brod) - depot: Vinski-GASPARINI 1973, 218, Tab. 49.3.

22. Pustakovec (Croatia, Čakovec) - depot: HänSEL 1999, Abb. 5.1-2.

23. Brandgraben 1 (Austria, Styria) - depot: Windholz-KonRAD - PreßLinger 2004, Taf. 3.26.

24. Sazovice (Czech Republic, Zlín) - depot: Salaš 2005a, 388-390; 2005b, Tab. 269.8.

25. Siča/Lučica (Croatia, Kordun) - depot: Perkić - Ložnjak Dizdar 2005, T. 9.143.

26. Silovec (Slovenia, Brežice) - depot: ČERČE - ŠInKOveC 1995, 213-215, Pl. 125.9.

27. Slavonski Brod (Croatia, Slavonski Brod) - depot: Clausing 2003, Abb. 36.113.

28. Strassengel (Austria, Styria) - depot: Müller-KARPE 1959a, 277; 1959b, Taf. 126a.19.

29. Szécsény-Benczúrfalva-Majorhegy (Hungary, Nógrád) - depot: KeMEnCzei 1984, 120, 263, Taf. LIIIb.4.

30. Topličica 1 (Croatia, Konjšćina) - depot: VinSKI-GASPARINI 1973, 220-221, Tab. 76.32.

31. Veliko Nabrđe (Croatia, Drenje) - depot: VInSKi-GASPARINI 1973, 211, Tab. 44.29.

Individual variants

32. Budinšćina (Croatia, Konjšćina) - depot: VINSKI-GASPARINI 1973, 212, Taf. 78.22.

33. Bükkszentlászló/Óhuta (Hungary, Borsod-Abaúj-Zemplén) - depot: Mozsolics 2000, 36-37, Taf. 6.3.

34. Brodski Varoš (Croatia, Slavonski Brod) - depot: VInsKi-GASPARINi 1973, 212, Tab. 52.29.

35. Nadap (Hungary, Fejér) - depot: MAкKAY 2006, XXIII. tábla 210.212.

36. Chergeş/Kerges (Romania, Hunedoara) - depot: Petrescu-Dîmboviţa 1978, 117, Taf. 88.6.

37. Parád-Várhegy (Hungary, Heves) - depot: V. SzABó 2011, Taf. 4.6.

List 11.3. 3a.) Torques with densely torsion (pseudo-torsion)

1. Arndorf (Austria, Styria) - grave 25: Wels-Weyrauch 1978, 161.

2. Badacsonytomaj (Hungary, Veszprém) - depot: Mozsolics 1985, 87-88, Taf. 236.7.

3. Bad Homburg (Germany, Hesse) - depot: Wels-Veyrauch 1978, 160, Taf. 67.880.

4. Bamberg (Germany, Upper Franconia) - grave: Wels-Weyrauch 1978, 160, Taf. 66.875.

5. Banatska Topola (Serbia, Banat) - depot: VAsIĆ 2010, 38, Taf. 22.151.

6. region of Belgrád (Serbia, Belgrad) - depot: VAsić 2010, 38, Taf. 22.152-154.

7. Biatorbágy-Herceghalom (Hungary, Pest) - depot: Mozsolics 1985, 127-128, Taf. 238.2-5.

8. Bokavić (Bosnia and Hercegovina, Lukavac) - depot: KöNIG 2004, 184-191, Taf. 43.129.

9. region of Bonyhád (Hungary, Tolna) - depot: Mozsolics 1985, 102-104, Taf. 39.30.36.

10. Boršice 2 (Czech Republic, Uherské Hradiště) - depot: SALAš 2005a, 412; 2005b, Tab. 323.5.

11. Budapest-Békásmegyer (Hungary, Pest) - grave 48: KAliCz-SchreiBer 2010, 45-46, Taf. 27.13.

12. Bükkaranyos 1 (Hungary, Borsod-Abaúj-Zemplén) - depot: KemenCzei 1984, 145, Taf. CXX.19.

13. Bükkaranyos 3 (Hungary, Borsod-Abaúj-Zemplén) - depot: Mozsolics 2000, 36, Taf. 5.3.

14. Brodski Varoš (Coratia, Slavonski Brod) - depot: Vinski-GASPARINi 1973, 212, Tab. 52.50, Tab. 59.11.

15. Častolovice (Czech Republic, Rychnov nad Kněžnou) - depot: Kytlicová 2007, 256, Taf. 200A.6-7.

16. Chotín/Hetény (Slovakia, Komárno) -grave 40, 59, 181, 203, 293, 326: Novotná 1984, 31, Taf. 38.244-245, Taf. 39.246-247.251-252, Taf. 77A.249.

17. Chotín/Hetény 2 (Slovakia, Komárno) - cemetery: NovotnÁ 1984, 31, Taf. 40.256.

18. Dridu (Romania, Ialomiţa) - depot: ENĂchiuc 1995, Abb. 3.7-8, Abb. 4.4-6.

19. Eßfeld (Germany, Würzburg) - grave: Wels-Weyrauch 1978, 160, Taf. 67.879.

20. Futog/Futak (Serbia, Bačka) - depot: VAsıć 2010, 38, Taf. 23.161-164.

21. Fridolfing (Germany, Traunstein) - depot: Koschiк 1981, Abb. 3.1.

22. Gaj/Gálya (Serbia, Banat) - depot: VAsić 2010, 39, Taf. 24.167-169, Taf. 25.170-171.

23. Gemer (Slovakia, Gemer) - stray find: Novotná 1984, 31, Taf. 39.250.

24. Gundheim (Germany, Rhineland-Palatine) - grave: Wels-Weyrauch 1978, 160, Taf. 66.876.

25. Gundersheim (Germany, Rhineland-Palatine) - grave: Wels-WeYrauch 1978, 161, Taf. 66.882.

26. Grünwald (Germany, München) - grave 16: MüllER-KARPE 1959a, 298, Taf. 182B.6.

27. Haidach (Austria, Carinthia) - depot: Müller-KARPE 1959a, 278; 1959b, Taf. 128.8.

28. Haindorf (Austria, Lower Austria) - individual find: Lochner 1991, 80, Taf. 56.5.

29. Haindorf 1 (Austria, Lower Austria) - depot: Lochner 1991, 185, 188, Taf. 50.1. 
30. Hradištko (Czech Republic, Kolín) - depot: Kytlicová 2007, 266, Taf. 188.1.

31. Ivanec Bistranski (Croatia, Zaprešić) - depot: VINSKI-GASPARINI 1973, 214, Tab. 113.10.

32. Jenišovice (Czech Republic, Mělník) - depot: Kytuicová 2007, 267-268, Taf. 101.16-22.

33. Jobaháza (Hungary, Győr-Moson-Sopron) - depot: Mozsolics 2000, 50, Taf. 41.2.

34. Kamenný Most/Kőhídgyarmat (Hungary, Nové Zámky) - depot: Novotná 1983, 31, Taf. 39.249.

35. Kamena Gorica (Croatia, Varažin) - depot: Vinski-GASPARINi 1973, 215, Tab. 126B.10.

36. Kenderes (Croatia, Jász-Nagykun-Szolnok) - depot: Mozsolics 2000, Taf. 49.1-3.

37. Keszőhidegkút (Hungary, Tolna) - depot: Mozsolics 1985, 135-137, Taf. 35.28-29.

38. Kundratice (Czech Republic, Litoměrice) - depot: Kytlicová 2007, 271-272, Taf. 113.1-2.

39. Kurd (Hungary, Tolna) - depot: Mozsolics 1985, 140-141, Taf. 25.3.

40. Ludwigshafen (Germany, Rhineland-Palatine) - grave: Wels-Weyrauch 1978, Taf. 67.877.

41. Liščín 1 - Maškovice (Czech Republic, Litoměřice) - depot: KytlicovÁ 2007, 278-279, Taf. 109B.1.4-5.

42. Lysec (Czech Republic, Teplice) - depot: KytuicovÁ 2007, 280, Taf. 118B.2-3.

43. Lžovice (Czech Republic, Kolín) - depot: Kytuicová 2007, 280-281, Taf. 190.4.

44. Lžovice 7 (Czech Republic, Kolín) - depot: Kytlicová 2007, 282-283, Taf. 194.6-9.

45. Mačkovac (Croatia, Gradiška) - depot: Vinski-GASPARINi 1973, 216, Tab. 73.28.

46. Malhostovice 2 (Czech Republic, Brno-venkov) - depot: SAlAš 2005a, 353-354; 2005b, Tab. 195.3.

47. Maribor/Marburg an der Drau (Slovenia, Maribor) - cemetery: Müller-KARPE 1959a, 273; 1959 b, Taf. 118.47-48.

48. Márok (Hungary, Baranya) - depot: Mozsolics 1985, 146-149, Taf. 92.25.27.

49. Nadap (Hungary, Fejér) - depot: Makkay 2006, XXIV. tábla 213-214, XXV. tábla 237.239.

50. Uioara de Sus/Felsőmarújvár (Romania, Alba) - depot: Petrescu-Dîmboviţa 1978, 132-135, Taf. 201.1098.1102-1103.1109.

51. Pácin 3 (Hungary, Borsod-Abaúj-Zemplén) - depot: Mozsolics 2000, 64, Taf. 70.8.

52. Počúvadlo/Bacsófalva (Slovakia, Žiar nad Hronom) - depot: NovotnÁ 1984, 31, Taf. 39.253-254, Taf. 40.254A-B.

53. Pravčice 1 (Czech Republic, Kroměříž) - depot: SAlaš 2005a, 450; 2005b, Tab. 413B.3, Tab. 414.1-2.4, Tab. 415.5-6.8, Tab. 416A.7.

54. Pričac (Croatia, Slavonski Brod) - depot: Vinski-Gasparini 1973, 218, Tab. 71.33.37.

55. Románd (Hungary, Veszprém) - depot: Mozsolics 2000, 70-73, Taf. 86.23-26.

56. Siča/Lučica (Croatia, Kordun) - depot: Perkić - LožnJak Dizdar 2005, T. 9.146.

57. Slovakia - unknown: NovotNÁ 1984, 31, Taf. 40.255.

58. Slovakia - unknown: NovotNÁ 1984, 31, Taf. 40.257.

59. Steinkirchen 10 (Germany, Lower Bavaria) - cemetery: Eckers 1996, 24, Taf. 14.6e.

60. Tab (Hungary, Somogy) - depot: Mozsolics 1985, 199, Taf. 116.12.

61. Tatabánya-Bánhida (Hungary, Komárom) - depot: Kemenczei 1983, 2. kép 1-3.

62. Tolcsva-Várhegy (Hungary, Borsod-Abaúj-Zemplén) - depot: V. SzABó 2013, 798-801, Fig. 3.3, Fig. 5.4.

63. Velika Gorica 2/1910 (Croatia, Zagreb) - grave 3/916: KARAVANić 2009, Pl. 68.2-6.

64. Včelínce/Mehy/Méhi (Slovakia, Rimavská Sobota) - depot: PAulík 1965, 67, Tab. XIII.32.

65. Wiesbaden (Germany, Hesse) - depot: Wels-Weyrauch 1978, 161, Taf. 67.883.

66. Zastávka (Czech Republic, Brno-venkov) - depot: SALAš 2005a, 457-461; 2005b, Tab. 466.1-3.

67. Záluži (Czech Republic, Litoměřice) - depot: KytuıCovÁ 2007, 316, Taf. 106.1-3.

Individual forms

68. Bükkszentlászló/Óhuta (Hungary, Borsod-Abaúj-Zemplén) - depot: Mozsolics 2000, 36-37, Taf. 6.1.

69. Maribor/Marburg (Slovenia) - cemetery: MÜLlER-KARPE 1959a, 273; 1959b, Taf. 118.45.

70. Monj (Bosnia and Hercegovina, Gračanica) - depot: KöNIG 2004, 209-211, Taf. 51.7.

71. Drenov dô (Bosnia and Hercegovina, Lopare) - depot: KöNIG 2004, 196-197, Taf. 56.11.

72. Krehin gradac (Bosnia and Hercegovina, Čitluk) - depot: KöNIG 2004, 200-203, Taf. 705.26.28.

73. Otok (Bosnia and Hercegovina, Ljubuški) - depot: KöNIG 2004, 215-216, Taf. 68.12-13, Taf. 69.14-1.

74. Velika Gorica 2/1910 (Croatia, Zagreb) - grave: Vinski-GasParini 1973, 221, Tab. 104.19.

75. Cabaj-Čápor/Cabaj/Csápor (Slovakia, Nitra) - grave: NovotnÁ 1984, 32, Taf. 40.262.

76. Uioara de Sus/Felsőmarújvár (Romania, Alba) - depot: Petrescu-DîmboviţA 1978, 132-135, Taf. 201.1104.

77. Trenčianske Bohuslavice/Bogoszló (Slovakia, Trenčín) - depot: NovotnÁ 1984, 32, Taf. 40.263.

78. Kecel (Hungary, Bács-Kiskun) - private collection: Mozsolics 2000, 52-53, Taf. 46.1-2.

79. Ruše/Maria Rast (Slovenia, Maribor) - grave 62: Müller-Karpe 1959a, 270; 1959b, Taf. 110A.1.

80. Parád-Várhegy (Hungary, Heves) - depot: V. SzABó 2011, Taf. 4. 
List 11.4. 3b.) Loose torsion

1. Boršice 2 (Czech Republic, Uherské Hradiště) - depot: SAlaš 2005a, 412; 2005b, Tab. 323.3-4.

2. Brodski Varoš (Croatia, Slavonski Brod) - depot: VINSKi-GASPARINi 1973, 212, Tab. 52.54.

3. Bükkszentlászló/Óhuta (Hungary, Borsod-Abaúj-Zemplén) - depot: Mozsolics 2000, 36-37, Taf. 6.2-5.

4. Čitluk (Serbia, Soko Banja) - grave: VAsıć 2011, 36, Taf. 19.137.

5. Dridu (Romania, Ialomiţa) - depot: ENĂchiUc 1995, Abb. 4.6.

6. Jászkarajenő (Hungary, Pest) - depot: Mozsolics 1985, 129-130, Taf 251.18.

7. region of Kladovo (Serbia, Kladovo) - individual find: VAsić 2010, 36, Taf. 20.138.

8. Konjuša (Serbia, Osečina) - grave 1869: VAsić 2010, 36, Taf. 20.139.

9. Maribor/Marburg (Slovenia, Maribor) - cemetery: MüllER-KARPE 1959a, 273; 1959b, Taf. 118.44.

10. Mojsinje (Serbia, Čačak) - grave: VAsıć 2010, 36, Taf. 21.141.

11. Rohod-Somogyi 4 (Hungary, Szabolcs-Szatmár-Bereg) - depot: Mozsolics 2000, 69-70, Taf. 83.4-5.

12. Porta Bohemica-Labe (Czech Republic, Litoměřice) - depot: Kytlicová 2007, 292-293, Taf. 119.1-2.

13. Pričac (Croatia, Slavonski Brod) - depot: Vinski-Gasparini 1973, 218, Tab. 71.24.

14. Ram-Duna (Serbia, Golubac) - river find: VAsıć 2010, 36, Taf. 21.145.

15. Slatinice (Czech Republic, Olomouc) - depot: SALAŠ 2005a, 405-408; 2005b, Tab. 308.14.

16. Serbia - unknown: VASIć 2010, 36, Taf. 21.146.

17. Tešanj 2/Stanari (Bosnia and Hercegovina, Teslić) - depot: KöNIG 2004, 223-224, Taf. 32.3-4.

Individual forms

18. Bükkszentlászló/Óhuta (Hungary, Borsod-Abaúj-Zemplén) - depot: Mozsolics 2000, 36-37, Taf. 6.2.4-5.

19. Bratislava/Pozsony (Slovakia, Bratislava) - unknown: Novotná 1984, 33, Taf. 41.270.

20. region of Hlohovec/Galgóc/Freistadt (Slovakia, Trnava) - uncertain depot: NovotnÁ 1984, 33, Taf. 42.267-269.

21. Dridu (Romania, Ialomiţa) - depot: ENĂchIUc 1995, Abb. 3.1-3.

List 11.5. 4.) Troques decorated with lines and torsion

1. Gemer/Gömör (Slovakia, Gemer) - depot: NovotnÁ 1984, 32, Taf. 40.258.

2. Keszőhidegkút (Hungary, Tolna) - depot: unpublished.

3. Včelínce/Mehy/Méhi (Slovakia, Rimavská Sobota) - unknown: NovotnÁ 1984, 32, Taf. 40.260.

4. Žírany/Zsére (Slovakia, Nitra) - individual find: NovotnÁ 1984, 32, Taf. 40.261.

5. Drenov dô (Bosnia and Hercegovina, Lopare) - depot: KöNIG 2004, 196-197, Taf. 56.11-12.

Unclassifiable torques

1. region of Bonyhád (Hungary, Tolna) - depot: Mozsolics 1985, 102-104, Taf. 39.34.

2. Budapest-Békásmegyer (Hungary, Pest) - grave 124: KALICZ-Schreiber 2010, 85-86, Taf. 60.4.

3. Futog/Futak (Serbia, Novi Sad, Bačka) - depot: Vasıć 2010, 38, Taf. 23.165.

4. Siča/Lučica (Croatia, Kordun) - depot: Perkić - Ložnjak Dizdar 2005, T. 9.144-145.147.

5. Jobaháza (Hungary, Győr-Moson-Sopron) - depot: Mozsolics 2000, 50, Taf. 41.1.

\section{List 12. Round-sectioned ring with line decoration}

1. Bokavić (Bosnia and Hercegovina, Lukavac) - depot: KöNIg 2004, 184-191, Taf. 44. 150-160, Taf. 45. 163.170.172.

2. Fonyód (Hungary, Somogy) - grave: Szentmártoni Darnay 1905, 1. kép 2.

3. Gyermely (Hungary, Komárom-Esztergom) - depot: Mozsolics 1985, 121-122.

4. Kisdorog-Hegyiszántók (Hungary, Tolna) - depot: SzABó 1996, 207-210, Fig 1.

5. Lengyeltóti 2 (Hungary, Somogy) - depot: WANZEK 1992, Abb. 2.

6. Monj (Bosnia and Hercegovina, Gračanica) - depot: KöNIG 2004, 209-211, Taf. 52.12-20, Taf. 53.21-30, Taf. 54.31-40.

7. Nádudvar (Hungary, Hajdú-Bihar) - depot: Mozsolics 2000, 57-59, Taf. 58.15.

8. Srpska Varoš (Bosnia and Hercegovina, Tešanj) - depot: König 2004, 219, Taf. 50B.3.

9. Sălard/Szalárd (Romania, Bihor) - depot: Petrescu-Dîmboviţa 1998, 80, Taf. 68.839.

10. Szentes-Nagyhegy 3 (Hungary, Csongrád) - depot: Mozsolics 2000, 77-78, Taf. 94.1.

\section{List 13. Rings with pointed terminals}

1. Antonovka/Antalovci/Antalovcy 2 (Ukraine, Užgorod) - depot: KoBAL’ 2000, 73, Taf. 43B.1-5.

2. Arad 2 (Romania, Arad) - depot: Petrescu-Dîmboviţa 1978, 139, Taf. 223A.44-50; Taf. 224.35-43. 
3. Balatonudvari-Fövenyes (Hungary, Veszprém) - depot: TARBAY 2013, 279, C. Katalógus - 10. tábla 43-51.

4. Biatorbágy-Herceghalom (Hungary, Pest) - depot: Mozsolics 1985, 127-128, Taf. 238.8-23.

5. Bokavić (Bosnia and Herzegovina, Lukavac) - depot: KöNIG 2004, 184-191, Taf. 44.143-144, Taf. 45.175185, Taf. 46.186-207, Taf. 47.219-228.

6. Bokod (Hungary, Komárom-Esztergom) - depot: PATAy 1964, 2. ábra 2.4-5, 3. ábra 1-12.

7. Berkesz (Hungary, Szabolcs-Szatmár-Bereg) - depot: Mozsolics 1985, 96-97, Taf. 177.15-18.

8. Čopovka/Čopivka/Beregardó (Ukraine, Beregovo) - depot: KoBAL' 2000, 78-79, Taf. 71.5.8-18.

9. Csepel-Duna szakasz (Hungary, Pest) - depot: SzILAs 2003, 4. kép 4-7.

10. Dévaványa 2 (Hungary, Békés) - depot: Mozsolics 2000, 41-42, Taf. 25.25.

11. Gyermely-Szomor (Hungary, Komárom) - depot: Mozsolics 1985, 121-122, Taf. 241.18-20, Taf. 242.1-59.

12. Gyöngyössolymos-Kishegy 2 (Hungary, Heves) - depot: KemenCZEI 1972, II. tábla 16-19.

13. Gyöngyössolymos-Kishegy 4 (Hungary, Heves) - depot: KeMENCZEI 1980, VII. tábla 1-18.

14. Hódmezővásárhely (Hungary, Csongrád) - depot: Mozsolics 1985, 128, Taf. 256.1-3.

15. Kammený Most/Kőhídgyarmat (Slovakia, Nové Zámky) - depot: Novotná 2000, 375, Obr. 8.3-4.6-8.

16. Kék (Hungary, Szabolcs-Szatmár-Bereg) - depot: Kemenczei 1984, 174-175, Taf. CLXXXII. 6-13.

17. Kemecse 3 (Hungary, Szabolcs-Szatmár-Bereg) - depot: Mozsolics 1985, 132-134, Taf. 186.26-27.

18. Kopčany/Kopcsány (Slovakia, Trebišov) - depot: DemeterovÁ-Polláková 1973, Tab. I.1-11, Tab. II. 9-12.

19. Lengyeltóti 3 (Hungary, Somogy) - depot: Mozsolics 1985, 142-143, Taf. 109.1-3.10-34.

20. Lesenceistvánd 1 (Hungary Veszprém) - depot: Mozsolics 1985, 144.

21. Lesenceistvánd/Uzsavölgy 2 (Hungary, Veszprém) - depot: Mozsolics 1985, 144, Taf. 270B.

22. Lovasberény (Hungary, Fejér) - depot: Mozsolics 1985, 144-145, Taf. 246.18-20.

23. Medeno Polje (Bosnia and Hercegovina, Banja Luka) - depot: KöNIG 2004, 208-209, Taf. 31B.2.4-5.

24. Medvež'e/Medveže/Medvefalva (Ukrajna, Volovec) - depot: KoвAL' 2000, 87-88, Taf. 57B.3-20, Taf. 58. 21-35, Taf. 59.36-41.43-47.

25. Mérk (Hungary, Szabolcs-Szatmár-Bereg) - depot: Mozsolics 2000, 55, Taf. 58.16.

26. Moigrad/Mojgrád (Romania, Sălaj) - depot: Petrescu-DîmboviţA 1978, 143, Taf. 235.23-35, Taf. 236A.36-50.

27. Nadap (Hungary, Fejér) - depot: MAкKAY 2006, XXV. tábla 233.

28. Nagydobsza (Hungary, Baranya) - depot: TARBAY 2013 - Katalógus B - 30. tábla 60.

29. Užgorod/Uzsgorod 4 (Ukraine, Užgorod) - depot: KoBAL’ 2000, 97, Taf. 70.8.11-19.23-24.

30. region of Užgorod/Uzsgorod 6 (Ukraine, Užgorod) - depot: KoBAL' 2000, 97, Taf. 78A.1-3.

31. Obava/Dunkófalva 1 (Ukraine, Munkačevo) - depot: KoBAL' 2000, 90, Taf. 63.13-21.

32. Ořechov (Croatia, Brno-venkov) - depot: SALAš 2005a, 373-376; 2005b, Tab. 242.55-58.

33. Öreglak (Hungary, Somogy) - depot: Mozsolics 1985, 163-165, Taf. 76.12, Taf. 84.5-8.10.

34. Regöly-Veravár (Hungary, Tolna) - depot: SzABó 1993, 6. tábla 11.13.15-17.20.22.

35. Rétközberencs (Hungary, Szabolcs-Szatmár-Bereg) - depot: Mozsolics 1985, 182, Taf. 193.10-2.

36. Sălard/Szalárd (Romania, Bihor) - depot: Petrescu-DîmboviţA 1978, 144, Taf. 240.31-56.

37. Somogyszob (Hungary, Somogy) - depot: Mozsolics 1985, 187, Taf. 249.1-27.

38. Srpska Varoš (Bosnia and Herzegovina, Tešanj) - depot: KöNIG 2004, 219, Taf. 50B.3-4.

39. Suskovo/Szuszkó 1 /Bányfalu(Ukraine, Svaljava) - depot: KoBAL’2000, 95-96, Taf. 74B.8-9.

40. Szakály-Fütyülős dülő (Hungary, Tolna) - depot: SzABó 1996, 210-212, Fig. 5.10.

41. Szentes-Nagyhegy (Hungary, Csongrád) - depot: Mozsolics 2000, 77-78, Taf. 94.4-5.

42. Székesfehérvár (Hungary, Fejér) - depot: F. PETres 1960, 11, ábra 2-3.5.7.

43. Tatabánya-Bánhida (Hungary, Komárom-Esztergom) - depot: Kemenczei 1983, 1. kép 4-13.

44. Tatabánya-Ótelep (Hungary, Komárom-Esztergom) - depot: JungBert 1986, Abb. 2.3-6, Abb. 3.1-5.

45. Tešanj 2/Stanari (Bosnia and Herzegovina, Teslić) - depot: KöNIG 2004, 223-224, Taf. 32.6-13, Taf. 33.1426, Taf. 34.26-37, Taf. 35.38-49, Taf. 36.50-65.

46. Tiszanagyfalu (Hungary, Szabolcs-Szatmár-Bereg) - depot: Mozsolics 1985, 204, Taf. 196.8-18.

47. Tiszavasvári (Hungary, Szabolcs-Szatmár-Bereg) - depot: Mozsolics 1985, 205, Taf. 262.2-10.

48. Trenčianske Bohuslavice/Bogoszló (Slovakia, Trenčiansky) - depot: NovotnÁ 1970a, Taf. XVI.

49. Velem (Hungary, Vas) - depot: Mozsolics 1985, 211, Taf. 228.20-30.

50. Žbince/Nagycseb (Slovakia, Michalovce) - depot: NovotnÁ 1970a, 126-127, Taf. XXVI.

51. Zvolen-Pod pustým hradom (Slovakia, Zvolen) - depot: Novotná 1970a, 124, Taf. XI.

\section{List 14. Rings with rhomboid cross section}

1. Balatonudvari-Fövenyes (Hungary, Veszprém) - depot: TARBAY 2013, 279, Katalógus C - 10. tábla, 53-54.

2. Banka (Slovakia, Trnava) - depot: NovotnÁ 1970a, Taf. XLIX.

3. Bátaszék (Hungary, Tolna) - depot: Mozsolics 1985, 95, Taf. 269.8-9.

4. Beremend (Hungary, Baranya) - depot: Mozsolics 1985, 95-96, Taf. 254.2-3.

5. Bodrog (Slovakia, Košice) - depot: NovotnÁ 1970a, 91, Taf. XVIII. 
6. Boljanić (Bosnia and Herzegovina, Gračanica) - depot: KöNIG 2004, 191-194, Taf. 19.86-88.

7. Biatorbágy-Herceghalom (Hungary, Pest) - depot: Mozsolics 1985, 127-128, Taf. 238.6-7.

8. Bükkaranyos (Hungary, Borsod-Abaúj-Zemplén) - depot: Kemenczei 1984, 145, Taf. CXX.21.

9. Čermožišče/Tschermoschnitz (Slovenia, Žetale) - depot: ČERČE - ŠINKOVEC 1995, 149-159, Pl. 58.60.

10. Celldömölk-Sághegy 2 (Hungary, Vas) - depot: Mozsolics 2000, 37-38, Taf. 16.8-9.

11. Detva (Slovakia, Zvolen) - depot: Novotná 1970a, 92-93, Taf. XLVI.

12. Dévaványa 2 (Hungary, Békés) - depot: Mozsolics 2000, 41-42, Taf. 25.24.

13. Drslavice 1 (Czech Republic, Uherské Hradiště) - depot: SALAš 2005a, 317-332; 2005b, Tab. 140.668.

14. Gîrbău/Magyargorbó (Romania, Cluj) - depot: SoroceAnu 1995, Abb. 3.5-6.8.11-12.14-15.18-20.22-23.

15. Gyermely-Szomor (Hungary, Komárom-Esztergom) - depot: Mozsolics 1985, 121-122, Taf. 240.11.

16. Geszt (Hungary, Borsod-Abaúj-Zemplén) - depot: SEnnovitz 1902, 1. tábla 3.

17. Lovasberény (Hungary, Fejér) - depot: Mozsolics 1985, 144-145, Taf. 246.21.

18. Lugoj/Lugos (Romania, Timiş) - depot: Petrescu-Dîmboviţa 1978, 122, Taf. 120.1-2.

19. Kloštar Ivanić (Croatia, Kloštar Ivanić) - depot: VINSKI-GASPARINI 1973, 215, Tab. 96.20.

20. Kučišta (Bosnia and Herzegovina, Bosanski Brod) - depot: König 2004, 203-206, Taf. 4.86.

21. Máriakéménd (Hungary, Baranya) - depot: Mozsolics 1985, 64, 146.

22. Mixnitz (Austria, Upper Styria) - depot: Müller-KARPE 1959a, 276; 1959b, Taf. 124d.14.

23. Moigrad/Mojgárd (Romania, Sălaj) - depot: Petrescu-DîmboviţA 1978, 143, Taf. 235.23-35, Taf. 236 A.46.

24. Mušov 2 (Croatia, Břeclav) - depot: SALAš 2005a, 357-371; 2005b, Tab. 200.8, Tab. 217.236.

25. Nagydobsza (Hungary, Baranya) - depot: TARBAy 2013, B Katalógus - 30. tábla 61.

26. Palotabozsok (Hungary, Baranya) - depot: Mozsolics 1985, 166-168, Taf. 75.28.

27. Plešivec/ Pelsőc (Slovakia, Košice) - depot: PAulík 1965, Tab. VIII.5.

28. Regöly-Vervár (Hungary, Tolna) - depot: SzABó 1993, 18. tábla 7.

29. Siča/Lučica (Croatia, Kordun) - depot: Perkić - Ložnjak Dizdar 2005, T. 8.127-133.

30. Soběsuky 2 (Czech Republic, Prostějov) - depot: Salaš 2005a, 453; 2005b, Tab. 426B.1-4, Tab. 427A.5.

31. Somogyszob (Hungary, Somogy) - depot: Mozsolics 1985, 187, Taf. 249.6.

32. Suskovo/Suskovo/Szuszkó 1 (Ukraine, Svaljava) - depó: KoBAL' 2000, 95-96, 74B.5.

33. Štramberk 1 (Czech Republic, Nový Jičín) - depot: SALAš 2005a, 454-455; 2005b, Tab. 430.5.

34. Szakály-Fütyülős (Hungary, Tolna) - depot: SzABó 1996, Fig. 5.

35. Szentes-Nagyhegy 1 (Hungary, Csongrád) - depot: Kemenczei 1996, Abb. 33.4.

36. Tatabánya-Bánhida (Hungary, Komárom) - depot: Kemenczei 1983, 1. kép 17.

37. Tállya (Magyarország, Borsod-Abaúj-Zemplén) - depot: Kemenczei 1969, VII.9-12.

38. Várvölgy-Nagy-Lázhegy (Hungary, Zala) - depot: Müller 2011, 4. ábra 13.

39. Velem (Hungary, Vas) - depot: Mozsolics 1985, 211, Taf. 228.10.

\section{List 15. Chained objects}

1. Bükkaranyos (Hungary, Borsod-Abaúj-Zemplén) - depot: KemenCZei 1984, 145, Taf. CXX.25.

2. Dridu (Romania, Jalomiţa) - depot: ENĂCHIUC 1995, Abb 3.1.3.8, Abb. 4.7, Abb. 8.17.22.

3. Drenov dô (Bosnia and Hercegovina, Lopare) - depot: KöNIG 2004, 196-197, Taf. 55.9.

4. Füzesabony (Hungary, Heves) - depot: Kemenczei 1984, 147, Taf. CXI.37.

5. Fridolfing (Germany, Traunstein) - depot: Koschiк 1981, Abb. 5.1-6.8.

6. Gemzse-Égetterdő (Hungary, Szabolcs-Szatmár-Bereg) - depot: Kacsó 2006, 103, Abb. 9.1-2.

7. Gheja/Marosgezse (Romania, Mureş) - depot: Petrescu-Dîmbovița 1978, 102, Taf. 33D.

8. Gărbău/Magyargorbó (Romania, Cluj) - depot: SoroceAnu 1995, Abb 2.11.

9. Guşteriţa/Szenterzsébet 2 (Romania, Sibiu) - depot: Petrescu-DîmboviţA 1978, 120-122, Taf. 116.310.

10. Hradištko (Czech Republic, Kolín) - depot: Kytlicová 2007, 266, Taf. 189A.37.

11. Jobaháza (Hungary, Győr-Moson-Sopron) - depot: Mozsolics 2000, 50, Taf. 41.7.

12. Kosmonosy (Czech Republic, Mladá Boles'lav) - depot: Kytuicová 2007, 269, Taf. 165.1-2.

13. Kundratice (Czech Republic, Litoměřice) - depot: KytLicovÁ 2007, 271-272, Taf. 114.27.

14. Krásna Hôrka/Krasznahorka (Slovakia, Rožňava) - depot: NovotnÁ 1970a, Taf. LV.

15. Liščín 1 - Maškovice (Czech Republic, Litoměřice) - depot: KytLiCovÁ 2007, 278-279, Taf. 110.26-27.

16. Magyartés (Hungary, Csongrád) - depot: Kemenczei 1984, 176, Taf. CLXXXd.4.

17. Moldova Veche 1 (Romania, Caraş-Severin) - depot: Petrescu-Dîmboviţa 1978, 122-123, Taf. 121.35-37.

18. Moldova Veche 3 (Romania, Caraş-Severin) - depot: Petrescu-Dîmboviţa 1978, 123, Taf. 122 B.

19. Nadap (Hungary, Fejér) - depot: MAKkAY 2006, XXV. tábla 237.

20. Uherská Hradiště/Magyarhradis (Czech Republic, Uherské Hradiště) - depot: SALAš 2005a, 465-466; 2005b, Tab. 458B.

21. Obava/Dunkófalva 1 (Ukraine, Munkačevo) - depot: KoBAL' 2000, 90, Taf. 62B.7a-f.

22. Palotabozsok (Hungary, Baranya) - depot: Mozsolics 1985, 166-168, Taf.75.2.7. 
23. Pescari/Coronini/Lászlóvára (Romania, Caraş-Severin) - depot: Petrescu-DîmboviţA 1978, 124, Taf. 129A.1.

24. Popeşti/Nádaspapfalva (Romania, Cluj) - depot: Petrescu-Dîmboviţa 1978, 124-125, Taf. 129B.27.

25. Porta Bohemica-Labe (Czech Republic, Litoměřice) - depot: Kytlicová 2007, 292-293, Taf. 121.33.

26. Přestavlky (Czech Republic, Přerov) - depot: SAlAš 2005a, 380-387; 2005b, Tab. 260.95.101.97.136.

27. Pustakovec (Croatia, Čakovec) - depot: Hänsel 1999, Abb. 5.1-5.

28. Rataje nad Sázavou 3 (Croatia, Kutná Hora) - depot: Kytlicová 2007, 299, Taf. 154.11-12.

29. Săcuieni/Székelyhíd (Romania, Bihor) - depot: Petrescu-DîmboviţA 1978, 144, Taf. 238B.21-23.

30. Sel'co 2 (Ukraine, Iršava) - depot: KoBAL' 2000, 94, Taf. 69.3-5.

31. Şpălnaca/Ispánlaka 1 (Romania, Alba) - depot: Petrescu-Dîmboviţa 1978, 145, Taf. 246.74.

32. Şpălnaca/Ispánlaka 2 (Romania, Alba) - depot: Petrescu-Dîmboviţa 1978, 127-131, Taf. 155.519-521.

33. Světec (Czech Republic, Teplice) - depot: Kytuicová 2007, 307-308, Taf. 152.8.

34. Szentes-Nagyhegy 3 (Hungary, Csongrád) - depot: Mozsolics 2000, 77-78, Taf. 94.6.

35. Szilvásvárad-Kelemenszéke (Hungary, Heves) - depot: V. SzABó 2011, Taf. 2.1.

36. Tatabánya-Bánhida (Hungary, Komárom) - depot: Kemenczei 1983, 2. kép 17.

37. Tetín 2 (Czech Republic, Beroum) - depot: Kytlicová 2007, 310, Taf. 141B.5.

38. Trnava (Czech Republic, Třebíč) - depot: SAlAš 2005a, 392-393; 2005b, Tab. 279.16.

39. Uioara de Sus/Felsőmarosújvár (Romania, Alba) - depot: Petrescu-Dîmboviţa 1978, 132-135, Taf. 205.1291, Taf. 206.1304-1305, 1311.

40. Želatovice (Czech Republic, Přerov) - depot: Salaš 2005a, 400; 2005b, Tab. 291A.6-10.

\section{List 16. Metal sheet tubes}

1. Badacsonytomaj-Köbölkút (Hungary, Veszprém) - depot: Mozsolics 1949, 28, XXVI. tábla 8-9.

2. Băleni (Romania, Galaţi) - depot: Petrescu-Dîmboviţa 1978, 109, Taf. 53.69-70.

3. Bodrog/Bodrogszentmária (Slovakia, Trebišov) - depot: NovotnÁ 1980, 103, Taf. 60.47-63.

4. Budapest-Békásmegyer (Hungary, Pest) - grave 338, 191: KAlicz-Schreiber 2010, 432, 504, Taf. 83.14.16, Taf. 155.1-5, Taf. 83.14.16.

5. Brodski Varoš (Croatia, Slavonski Brod) - depot: Vinski-Gasparini 1973, 212, Tab. 55.17, Tab 57.39.61.

6. Caransebeş/Karánsebes (Romania, Caraş-Severin) - depot: Petrescu-DîmboviţA 1978, 116-117, Taf. 87.54-55.

7. Dombóvár-Szarvasd puszta (Hungary, Tolna) - depot: MÉszÁros 1977 - 1978, 21, VII. tábla 9-10.

8. Drslavice 1 (Czech Republic, Uherské Hradiště) - depot: SALAš 2005a, 317-332; 2005b, Tab. 140.689-690.

9. Esztergom-Kistói dülő (Hungary, Komárom-Esztergom) - depot: Mozsolics 1985, 116-118, Taf. 138.20-23.

10. Gemer/Sajógömör (Slovakia, Gemer) - depot: HAMPEL 1886b, IV. tábla 8.

11. Gyöngyössolymos 1 (Hungary, Heves) - depot: KeMENCzei 1972, VI. tábla 14.

12. Gyöngyössolymos-Kishegy 4 (Hungary, Heves) - depot: Kemenczei 1980, VI. tábla 19-24.

13. Hočko Pohorje (Slovenia, Hoče-Slivnica) - depot: ČERČE - ŠInKovec 1995, 177-195, Pl. 84.172.

14. Jarak 1 (Croatia, Hrtkovci) - depot: VinsKi-GASPARINI 1973, 214, Tab. 83.11.

15. Lengyeltóti 2 (Hungary, Somogy) - depot: WAnzek 1992, Taf. 1.25, Taf. 10.10.

16. Kemecse (Hungary, Szabolcs-Szatmár-Bereg) - depot: HAMPEL 1896, CCXXIX. tábla 47.

17. Keszőhidegkút (Hungary, Tolna) - depot: Mozsolics 1985, 135-137.

18. Mackovac-Grunjac (Serbia, Banat) - depot: JovANOvić 2010, Tab. 65.552.554-555.

19. Mušov 2 (Czech Republic, Břeclav) - depot: SALAš 2005a, 357-371; 2005b, Tab. 218.258.260, Tab. 220.307-312.

20. Nadap (Hungary, Fejér) - depot: MAKKaY 2006, 145, XXXVI. tábla 332-335.

21. Nagyvejke (Hungary, Tolna) - depot: MÉszÁros 1971 - 1972, 45, XI. tábla 9-10, 12-13.

22. Pamuk (Hungary, Somogy) - depot: Mozsolics 1975, 9, VII. tábla 14.

23. Slavonski Brod (Croatia, Slavonski Brod) - depot: Vinski-GASPARINi 1973, Tab. 67.31.

24. Brandgraben 1 (Germany, Styria) - depot: Wilndholz-KonRAd - Preßlinger 2004, Taf. 3.43-45.

25. Regöly-Veravár (Hungary, Tolna) - depot: SzABó 1993, 4. tábla, 18.20-25.

26. Pölöske (Hungary, Zala) - depot: Mozsolics 1985, 177-178, Taf. 125.8.

27. Přestavlky (Czech Republic, Přerov) - depot: SAlAš 2005a, 380-387; 2005b, Tab. 265.15.

28. Rýdec (Czech Republic, Ústí nad Labem) - depot: Kytuicová 2007, 302-303, Taf. 87.67.207.

29. Sárospatak 2 (Hungary, Borsod-Abaúj-Zemplén) - depot: B. HellebrandT 1986, 6, 4. kép. 10.14-16.20-21.

30. Siča/Lučica (Horvátország, Kordun) - depot: Perkić - LožNJak Dizdar 2005, T. 10.168-172, T. 11.212-216.

31. Slatinice (Czech Republic, Olomouc) - depot: SALAš 2005a, 405-408; 2005b, Tab. 314.64-66.

32. Suseni/Marosfelfalu (Romania, Mureş) - depot: Petrescu-Dîmboviţa 1978, 127, Taf. 138.81.

33. Spălnaca/Ispánlaka 2 (Romania, Alba) - depot: Petrescu-Dîmboviţa 1978, 127-131, Taf. 152.439-447, Taf. 156.561.

34. Tállya (Hungary, Borsod-Abaúj-Zemplén) - depot: Mozsolics 1985, 200-201, Taf. 165.1.4-8.13.

35. Velehrad (Czech Republic, Uherské Hradišté) - depot: SAlaš 2005a, 296-297; 2005b, Tab. 285.15. 
36. Veliko-Nabrđe (Croatia, Drenje) - depot: VinSKI-GASPARINI 1973, 221, Tab. 44.21-22. 37. Wörschach (Austria, Styria) - grave: Modrijan 1953, Abb. D6.

\section{List 17. Žatec-Type buckets (Clausing 1996)}

1. Budinšćina (Croatia, Konjšćina) - depot: Vinski-GASPARINi 1973, 212, Taf. 79.16.

2. Brodski Varoš (Croatia, Slavonski Brod) - depot: Vinski-Gasparini 1973, 212, Tab. 55.23, Tab. 57.1-3.6.

3. Debeli vrh (Slovenia, Predgrad) - depot: ČERČE - ŠINKovec 1995, 159-169, Pl. 66.79.

4. Elsterwerda (Germany, Brandenburg) - depot: vON BRUNN 1968, 317, Taf. 62.55-56.

5. Heldenbergen (Germany, Hesse) - grave: Hermann 1966, 120, Taf. 111N.13.

6. Keszőhidegkút (Hungary, Tolna) - depot: Mozsolics 1985, 135-137, Taf. 35.33-34.38-39.

7. Kličevac 2 (Serbia, Požarevac) - depot: JacAnović 1994 - 1995, 104, 108, Abb. 6.3-4.

8. Lorscher Wald (Germany, Hesse) - grave: Hermann 1966, 151, Taf. 141D.2.

9. Mačkovac-Crišnjevi (Croatia, Gradiška) - depot: Karavanić - Mihaljević 2001, Tab. 9, Tab. 10, Tab. 11.4, Tab. 12.1.11.

10. Majdan/Magyarmajdány (Serbia, Vojvodina) - depot: Рашајски 1988, 21, Abb. 54.

11. Nadap (Hungary, Fejér) - depot: Makkay 2006, 139-140, Pl. VI.14, Pl. VII.15-16, Pl. VIII.17-30.

12. Nagyvejke (Hungary, Tolna) - depot: MÉszÁros 1971 - 1972, XV. tábla 7-10.

13. Obava/Dunkófalva 1 (Ukraine, Munkačevo) - depot: KoBAL' 2000, 67, 90, Taf. 62.12.

14. Očkov/Ocskó (Slovakia, Trenčín) - grave: PAulík 1962, 25-26, 59, Abb. 20.19-39, Abb. 25.1.2, Abb. 26.1.

15. Palotabozsok (Hungary, Baranya) - depot: Mozsolics 1985, 166-168, Taf. 75.31-33.

16. Pamuk (Hungary, Somogy) - depot: Mozsolics 1985, 168-169, Taf. 106.24.

17. Poljanci 2 (Croatia, Oprisavci) - depot: Holste 1951, 9, Taf. 15.23.

18. Popinci (Croatia, Syrmia) - depot: Holste 1951, 9, Taf. 15.23.

19. Rinyaszentkirály (Hungary, Somogy) - depot: Mozsolics 1985, 182-183, Taf. 96.1-2.

20. Rudnik (Serbia, Moravica) - depot: Гарашанин 1954, 29, Taf. 16.43.

21. Veliko Nabrde (Croatia, Drenje) - depot: Vinski-Gasparini 1973, 221, Tab. 44.21-22.

22. Weidachweis (Germany, Upper Bavaria) - depot: NAgler-ZANier 2010, Abb. 3.5-7, Abb. 8.5.

23. Žatec (Czech Republic, Louny) - grave: KytLicovÁ 1959, 127, 137, 154-155, Obr. 7-9.

Uncertain fragments

24. Bodrog (Slovakia, Trebišov) - depot: BUDINSKÝ - KRIČKA 1970, 40, Obr. 10.32-34.

25. Szentgáloskér (Hungary, Somogy) - depot: Mozsolics 1985, 194-195, Taf. 114.1.

25. Uioara de Sus/Felsőmarosújvár (Romania, Alba) - depot: SoroceAnu 2008, 207, Abb. 33c-d.

\section{List. 18. Half-forms}

\section{Hammer half-forms}

1. Nagydobsza (Hungary, Baranya) - depot: Fig. 35.62.

2. Lengyeltóti 3 (Hungary, Somogy) - depot: Mozsolics 1985, 142-143, Taf. 108.20-21.

Axe half-forms

3. Beremend (Hungary, Baranya) - depot: Mozsolics 1985, 95-96, Taf. 252.5.7-9.

4. Keszőhidegkút (Hungary, Tolna) - depot: Mozsolics 1985, 135-137, Taf. 35.5.

5. Kesztölc (Hungary, Komárom-Esztergom) - depot. Fig. 1.

6. Kurd (Hungary, Tolna) - depot: Mozsolics 1985, 140-141, Taf. 23.12.

7. Lovasberény (Hungary, Somogy) - depot: Mozsolics 1985, 144-155, Taf. 245.3.

1. Nagydobsza (Hungary, Baranya) - depot: Fig. 35.63-67.

Ring half-forms

9. Beregovo 4 (Ukraine, Beregovo) - depot: KoвAL' 2000, 74, Taf. 46B.2.

3. Beremend (Hungary, Baranya) - depot: Mozsolics 1985, 95-96, Taf. 254.1-4.

10. Hungary - unknown: HAMPEL 1886a, I. tábla 4.

11. Malaja Dobron' 2 (Ukraine, Užgorod) - depot: KoBAL' 2000, 86, Taf. 75.6.

12. Kloštar Ivanić (Croatia, Kloštar Ivanić) - depot: VINSKI-GASPARINI 1973, Tab. 96.15-18.

1. Nagydobsza (Hungary, Baranya) - depot: Fig. 35. 68-69. 
List 19. Rod ingots

1. Badacsonytomaj (Hungary, Veszprém) - depot: Mozsolics 1985, 87-88, Taf. 235.21-23.

2. Balsa (Hungary, Szabolcs-Szatmár-Bereg) - depot: Kemenczer 1984, 169-170, Taf. CLXVI.29-30.

3. Baks (Hungary, Csongrád) - individual find: V. SzABó 2011, Taf. 9.3.

4. Baks 1 (Hungary, Csongrád) - depot: V. Szabó 2011, Taf. 9.4.

5. Batrad'/Bótrágy (Ukraine, Beregovo) - depot: KoBAL' 2000, 73, Taf. 46A.14.

6. Bătărci/Batarcs (Romania, Satu Mare) - depot: Petrescu-Dîmboviţa 1978, 98, Taf. 21.52.

7. Bátaszék (Hungary, Tolna) - depot: Mozsolics 1985, 95, Taf. 269.3-4.

8. Beremend (Hungary, Baranya) - depot: Mozsolics 1985, 95-96, Taf. 254.11-14.

9. Biatorbágy (Hungary, Pest) - depot: Mozsolics 1985, Taf. 237.26.

10. Bingula-Divoš (Croatia, Stremska Mitrovica) - depot: VINSKI-Gasparini 1973, 211, Tab. 84.23.

11. Birján (Hungary, Baranya) - depot: Mozsolics 1985, 98-100, Taf. 68.5-7.

12. Bogdan Vodă/Izakonyha (Romania, Maramureş) - depot: MotzoI-ChicideAnU - IUGA 1995, Abb. 6.1-24, Abb. 7.6-7.

13. Bokavić (Bosnia and Hercegovina, Lukavac) - depot: KöNIG 2004, 184-191, Taf. 48.279-281.

14. Boljanić (Bosnia and Hercegovina, Gračanica) - depot: KöNIG 2004, 140, Taf. 19.91.

15. region of Bonyhád (Hungary, Tolna) - depot: Mozsolics 1985, 102-104, Taf. 39.4.

16. Borotin (Czech Republic, Blansko) - depot: SALAš 2005a, 307-309; 2005b, Tab. 93.39.

17. Boržava/Borzsova/Borzsa (Ukraine, Beregovo) - depot: KoBAL' 2000, 76, Taf. 55A.50-51.

18. Bošin (Czech Republic, Skořenice) - depot: Kytuicová 2007, 254, Taf. 184.1-26.

19. Bükkzsérc-Hódós-tető (Hungary, Borsod-Abaúj-Zemplén) - depot: V. SzABó - Bíró 2009, 8. kép 1.

20. Březovice (Czech Republic, Chrudim) - depot: Kytuicová 2007, 254-255, Taf. 180.14-17.

21. Brodski Varoš (Croatia, Slavonski Brod) - depot: Vinski-GASPARINI 1973, 212, Tab. 54.21.

22. Celldömölk-Sághegy 2 (Hungary, Vas) - depot: Mozsolics 2000, 37-38, Taf. 12.10.

23. Cetatea de Baltă/Küküllóvár (Romania, Alba) - depot: REZI 2009, Pl. 4.17-18.

24. Csabdi (Hungary, Fejér) - depot: Mozsolics 1985, 107, Taf. 248.5-6.

25. Cugir/Kudzsir/Kunendorf/Kudschir (Romania, Alba) - depot: Kacsó 2006, Abb. 18.6-16.

26. Dévaványa 2 (Hungary, Békés) - depot: Mozsolics 2000, 41-42, Taf. 25.20.

27. Dolné Janíky/Alsójányok (Slovakia, Bratislava) - depot: FurMÁNEK 1980, 13, Taf. 43.6-8.

28. Ecseg (Hungary, Nógrád) - depot: Kemenczei 1984, 146, Taf. CXVIa.20-21.

29. Füzesabony (Hungary, Heves) - depot: Mozsolics 1985, 119-120, Taf. 145.2-9.

30. Guşteriţa/Szenterzsébet/Hammersdorf 2 (Romania, Sibiu) - depot: Petrescu-Dîmboviţa 1978, 120 122, Taf. 118A.371.375.

31. Hočko Pohorje (Slovenia, Hoče-Slivnica) - depot: ČERČE - ŠInkovec 1995, 177-195, Pl. 86.209.

32. Kazincbarcika (Hungary, Borsod-Abaúj-Zemplén) - depot: Kemenczei 1984, 118, Taf. XLVIII.18.

33. Kemecse 2 (Hungary, Szabolcs-Szatmár-Bereg) - depot: Mozsolics 1985, 132, Taf. 190.2-3.

34. Kemecse 3 (Hungary, Szabolcs-Szatmár-bereg) - depot: Mozsolics 1985, 132-134, Taf. 185.30, Taf. 187.4-9.

35. Klobuky (Czech Republic, Kladno) - depot: Kytuicová 2007, 269, Taf. 57B.17.

36. Kloštar Ivanić (Croatia, Kloštar Ivanić) - depot: VINSKI-GASPARINI 1973, 215, Tab. 96.25-26.

37. Lazy/Lázárpatak 1 (Ukraine, Volovec) - depot: KoвAL' 2000, 84-85, Taf. 49.97.

38. Lisine (Croatia, Krstinja) - depot: VINSKI-GASPARINI 1973, 216, Tab. 97.8

39. Mackovac-Grunjac (Serbia, Banat) - depot: Jovanović 2010, Tab. 61.506.

40. Márok (Hungary, Baranya) - depot: Mozsolics 1985, 146-149, Taf. 95.8-11.

41. Medvež’e/Medveže/Medvefalva (Ukraine, Volovec) - depot: KовAL' 2000, 87-88, Taf. 60.64-67.

42. Meszlen (Hungary, Vas) - depot: Mozsolics 1985, 149, Taf. 232A.2.

43. Mušov 2 (Czech Republic, Břeclav) - depot: SALAš 2005a, 357-371; 2005b, Tab. 223.390-395.

44. Nagydém (Hungary, Veszprém) - depot: HAMPEL 1896, CXCV. tábla.10.

45. Nagyrábé (Hungary, Hajdú-Bihar) - depot: Mozsolics 2000, 60-61, Taf. 66.27-30.

46. Nagyhalász-Pálhalom dűlő (Hungary, Szabolcs-Szatmár-Bereg) - depot: Kemenczei 1984, 177, Taf. CLXXIIIc.4.

47. Nádudvar 2 (Hungary, Hajdú-Bihar) - depot: Mozsolics 2000, 57-59, Taf. 58.18.

48. Nyírtura (Hungary, Szabolcs-Szatmár-Bereg) - depot: Mozsolics 1985, 162-163, Taf. 204.13.

49. Uioara de Sus/Felsőmarosújvár (Romania, Alba) - depot: Petrescu-Dîmboviţa 1978, 132-135, Taf. 208.1464.1456-1458.1468-1470.1472-1477.

50. Palotabozsok (Hungary, Baranya) - depot: Mozsolics 1985, Taf. 74.24-25.

51. Püspökhatvan (Hungary, Pest) - depot: Mozsolics 1985, 178-179, Taf. 140.13-14.

52. Pölöske (Hungary, Zala) - depot: Mozsolıcs 1985, 177-178, Taf. 128.21.

53. Plešivec 7 (Czech Republic, Př́bram) - depot: Kytuicová 2007, 290-291, Taf. 36B.7.

54. Plešivec 8 (Czech Republic, Př́bram) - depot: Kytuicová 2007, 291, Taf. 38C.2. 
55. Podgorjany/Pidhorjany/Podhering 2 (Ukraine, Munkačevo) - depot: KoBAL' 2000, 93, Taf. 3.67-69.

56. Praha-Suchdol 2 (Czech Republic, Praha) - depot: Kytlicová 2007, 296-297, Taf. 52C.28.

57. Pravčice 2 (Czech Republic, Kroměríž) - depot: SAlaš 2005a, 378-379; 2005b, Tab. 250.8.

58. Přestavlky (Czech Republic, Přerov) - depot: SAlAš 2005a, 380-387; 2005b, Tab. 263.133.

59. Prosiměřice-Bohunice (Czech Republic, Znojmo) - depot: SAlaš 2005a, 379-380; SAlaš 2005b, Tab. $252.60-61$.

60. Rohod (Hungary, Szabolcs-Szatmár-Bereg) - depot: Kemenczei 1984, 182, Taf. CCXVIII.22.

61. Sárazsadány (Hungary, Borsod-Abaúj-Zemplén) - depot: KemenCZEI 1984, 182-183, Taf. CLXXVIIb.1.

62. Slavonski Brod (Croatia, Slavonski Brod) - depot: Clausing 2003, Abb. 42.202-203.

63. Suskovo/Szuszkó 1 (Ukraine, Svaljava) - depot: KoBAL' 2000, 95-96, Taf. 74.31.

64. Şpălnaca/Ispánlaka 1 (Romania, Alba) - depot: Petrescu-Dîmbovița 1978, 145, Taf. 247A.76-81.

65. Şpălnaca/Ispánlaka 2 (Romania, Alba) - depot: Petrescu-DîmboviţA 1978, 127-131, Taf. 157.609-611, Taf. 158.629.636.

66. Tállya (Hungary, Borsod-Abaúj-Zemplén) - depot: Mozsolics 1985, 185-186, Taf. 162.13.16.

67. Tiszaeszlár (Hungary, Szabolcs-Szatmár-Bereg) - depot: JósA - KeMENCZEi 1963 - 1964, Taf. LVIII.7.

68. Trenčianske Bohuslavice/Bogoszló (Slovakia, Trenčín) - depot: NovotnÁ 2000, Obr. 1.1-3.

69. Velem (Hungary, Vas) - settlement: Miske 1907, Taf. XX.9-15.

70. Žárovice-Hamry 2 (Czech Republic, Prostějov) - depot: SAlAš 2005a, 397-399; 2005b, Tab. 289.40.49.

71. Zvolen-Pustý A (Slovakia, Banskobystrický) - depot: Novotná 1970a, 124, Taf. VII.

\section{List 20. Tube with widened rim}

1. region of Bonyhád (Hungary, Tolna) - depot: HAMPEL 1892, CLIII. tábla 51.

2. Brück (Germany, Bavaria): PARE 2004, Abb. 6.2.

3. Egemose (Sydals, Denmark): PARE 2004, Abb. 6.8.

4. Gyöngyössolymos 1 (Hungary, Heves) - depot: SzÁnTó 1947, 4. kép 7.

5. Hart a. d. Alz (Germany, Bavaria) - grave: PARE 2004, Abb. 6.3.

6. Häder (Germany, Bavaria): PARE 2004, Abb. 6.1.

7. Janíky/Jányok (Slovakia, Trnava) - depot: Novotná 2000, Obr. 5.

8. Lazy/Lázárpatak 1 (Ukraine, Volovec) - depot: KoBAL' 2000, 85, Taf. 47.36.

9. Lengyeltóti 2 (Hungary, Somogy) - depot: WANZEK 1992, 263, Taf. 1.16, Taf. 10.14.

10. Mackovac-Grunjac (Serbia, Banat) - depot: Jovanović 2010, Tab. 60.503.

11. Mačkovac (Croatia) - depot: Karavanić - Mihaljević 2001, Tab 6.4.

12. Mušov 2 (Czech Republic, Břeclav) - depot: ŠAlas 2005a, 357-371; 2005b, Tab. 220.314.

13. Nagydém (Hungary, Veszprém) - depot: HAMPEL 1896, CXCV.15-16.

14. Ehingen (Germany, Swabia) - depot: MÜller-KARPE 1959a, 380-387; 1959b, Taf. 168.4.

15. Oberottmarshausen (Germany, Augsburg) - depot: BütTNER ET AL. 2006, Abb. 66.11.

16. Přestavlky (Czech Republic, Přerov) - depot: ŠAlAs 2005a, 3800-387; 2005b, Tab. 265.160-166; Tab. 266.167-168.

17. Rinyaszentkirály (Hungary, Somogy) - depot: Mozsolics 1985, 182-183, Taf. 97.16.

18. Schiltern (Austria, Seebenstein) - depot: HANSEN 1994, Abb. 80.5.

19. Služin-Zábrusky (Czech Republic, Prostějov) - depot: SAlAš - ŠMID 1999, 32, Abb. 10.22.

20. Tállya (Hungary, Borsod-Abaúj-Zemplén) - depot: Kemenczei 1966, XII. tábla 3.

21. Velem 1 (Hungary, Vas) - depot: Mozsolics 1985, 211-213, Taf. 231A.30.

22. Zürich-Wollishofen (Schweiz, Zürich): PARE 2004, Abb. 6.7. 


\section{Catalogue}

(Abbreviations: 1 - length; w1 - width; w2 - weight; th - thickness; d1 - diameter; $\mathbf{h}$ - height; o. 1. - outstretched length; d2 - depth)

1. Spear: Due to the blades fragmented state, the original form is hard to reconstruct. The analyzed spearhead has a short, cylindrical-sectioned conical socket and a sub-triangular blade with angular base. Two rivet holes are visible along its socket. The twisted form of the object can be a result of heat damage. No traces of casting faults are visible on its surfaces, however it is intensively corroded. The polishing of the casting seams on the narrow sides is superficial (Fig. 45.1).

1.: $8.5 \mathrm{~cm}$, w1.: $29.4 \mathrm{~cm}$, l. of the socket: $2.3 \mathrm{~cm}$, d. of the socket: $1.4 \mathrm{~cm}$, w2.: $34.7 \mathrm{~g}$

2. Spear fragment: Narrow edge fragment of a spear. An oval damage mark is visible along the central rib which might be connected with peri-depositional bending and breaking of the object (possible by the aid of a socketed chisel). Traces of sharpening and nicks could be observed along the edges. It is uncertain that the previous one can be interpreted as the result of using (Fig. 45.2).

l.: $3.6 \mathrm{~cm}, \mathrm{w} 1: 2.38 \mathrm{~cm}, \mathrm{w} 2 .: 10.39 \mathrm{~g}$

3. Spear fragment: Small fragment of a spear. Sharpening can be well-observed along the edges (Fig. 45.3). l.: $2.2 \mathrm{~cm}, \mathrm{w} 1 .: 22.2 \mathrm{~cm}, \mathrm{w} 2 .: 5.40 \mathrm{~g}$

4. Socketed axe: A socketed axes with thickened mouth and straight, oval-sectioned body. The object is composed of six smaller and one greater fragment. A rivet hole is visible along the narrow side. Its pattern composed of three horizontal, two broken and one Y and V ribs. Porosity and traces of casting faults can be observed along its external- and breakage surfaces. Its body parts are horizontally shifted due to the imprecise contact of the bivalve mould. As a result of the edges fragmented state, no traces of sharpening or usage can be observed. The polishing of the casting seams on the narrow sides is superficial (Fig. 46.4.1-4.6). Overall dimensions: $1 .: 12.3 \mathrm{~cm}$ (estimated overall $1 .: 14.1 \mathrm{~cm}$ ), w1.: $4.9 \mathrm{~cm}, 4.2 \mathrm{~cm}$, w2.: $284 \mathrm{~g}+55 \mathrm{~g}$ (fragments), d. of the socket: $3.4 \mathrm{~cm} \times 2.3 \mathrm{~cm}, \mathrm{~d} 2$. of the socket: $7.9 \mathrm{~cm}$

4.1. $3.6 \mathrm{~cm} \times 2.6 \mathrm{~cm}$, w2.: $14 \mathrm{~g}$, th.: $0.7 \mathrm{~cm}, 0.2 \mathrm{~cm}$

4.2. $3.8 \mathrm{~cm} \times 3 \mathrm{~cm}$, w2.: $12 \mathrm{~g}$, th.: $1 \mathrm{~cm}, 0.3 \mathrm{~cm}$

4.3. $3.1 \mathrm{~cm} \times 3.2 \mathrm{~cm}, \mathrm{w} 2 .: 15 \mathrm{~g}$, th.: $0.7 \mathrm{~cm}, 0.3 \mathrm{~cm}$

4.4. $2.9 \mathrm{~cm} \times 2 \mathrm{~cm}$, th.: $0.3 \mathrm{~cm}, \mathrm{w} 2 .: 5 \mathrm{~g}$

4.5. $2.2 \mathrm{~cm} \times 2.1 \mathrm{~cm}$, th.: $0.5 \mathrm{~cm}, \mathrm{w} 2 .: 6 \mathrm{~g}$

4.6. $1.3 \times 1.9 \mathrm{~cm}$, th.: $0.5 \mathrm{~cm}, \mathrm{w} 2 .: 1 \mathrm{~g}$

5. Fragment of a socketed axe: Broad side fragment of a socketed axe. Its breakage surfaces are porous. Six diagonal damage marks are visible along the external surface. The patterns compose of one verticaland four V ribs (Fig. 46.5).

1.: $3 \mathrm{~cm}, \mathrm{w} 1 .: 2.3 \mathrm{~cm}, \mathrm{w} 2 .: 10.81 \mathrm{~g}$, th.: $0.3 \mathrm{~cm}$

6. Socketed axe: Undecorated oval-sectioned socketed axe with thickened mouth and straight body. The body parts are slightly shifted due to the imprecise contact of the bivalve mould. The external surfaces are mostly smooth but porosity can be observed in certain parts. Depressions are visible on one of the broad sides, and overflow can be detected on the mouth. No traces of hammering or sharpening are visible on its edge (Fig. 47.6).

1.: $14 \mathrm{~cm}$, w1.: $5.3 \mathrm{~cm}, 5.6 \mathrm{~cm}, \mathrm{w} 2 .: 442.63 \mathrm{~g}$, d. of the socket.: $3.2 \mathrm{~cm} \times 2.6 \mathrm{~cm}$, d. of the socket.: $7.1 \mathrm{~cm}$

7. Socketed axe: Undecorated, oval-sectioned socketed axe with straight body and thickened mouth. Corrosion damage can be observed along the external surfaces of the object (Fig. 47.7).

1.: $9.8 \mathrm{~cm}$, w1.: $4.2 \mathrm{~cm}, 4.7 \mathrm{~cm}, \mathrm{w} 2 .: 289.78 \mathrm{~g}$, d1. of the socket.: $3 \mathrm{~cm} \times 2.5 \mathrm{~cm}, \mathrm{~d} 2$. of the socket: $6.3 \mathrm{~cm}$

8. Socketed axe: Undecorated, oval-sectioned socketed axe with narrow body and thickened mouth. The surfaces are basically smooth although traces of corrosion are visible. The body parts are shifted and overflow can be observed on the mouth. The casting seams are not polished entirely. Traces of hammering cannot be detected along the edges (Fig. 48.8).

1.: $12.6 \mathrm{~cm}$, w1.: $3.7 \mathrm{~cm}, 4.2 \mathrm{~cm}$, w2.: $233,45 \mathrm{~g}$, d1. of the socket: $2.8 \mathrm{~cm} \times 2.3 \mathrm{~cm}, \mathrm{~d} 2$ of the socket: $4.7 \mathrm{~cm}$

9. Socketed axe: Undecorated, oval-sectioned socketed axe with slightly thickened mouth. Its surface is smooth although traces of corrosion, cracks and even porosity are visible on it. The body parts are shifted due to the imprecise contact of the bivalve mould. Further casting faults can be seen like the overflow of the mouth, unpolished casting seams and asymmetry. In addition, the socket is dysfunctional as a result of the imprecise positioning of the core (Fig. 48.9).

l.: $12 \mathrm{~cm}$, w1.: $3.5 \mathrm{~cm}, 3.9 \mathrm{~cm}, \mathrm{w} 2 .: 240,09 \mathrm{~g}$, d1. of the socket.: $2.1 \mathrm{~cm} \times 1.8 \mathrm{~cm}$, d2. of the socket.: $2.9 \mathrm{~cm}$ 
10. Socketed axe: Undecorated, oval-sectioned socketed axe with narrow body. The breakage is probably the result of the body parts asymmetry. The surface of the object is smooth although a greater impression can be detected along the broad side near to the mouth (Fig. 49.10).

l.: $10.9 \mathrm{~cm}, \mathrm{w} 1 .: 2.8 \mathrm{~cm}, 3.5 \mathrm{~cm}, \mathrm{w} 2 .: 142.36 \mathrm{~g}$

11. Fragment of a socketed axe: Upper part of a socketed axe with narrow, curve body and slightly thickened mouth. Its casting is asymmetrical and its body parts are shifted. The fragments surface is basically smooth, although porosity can be detected on the mouth. A greater hiatus is visible on the broad side (Fig. 49.11). l.: $2.1 \mathrm{~cm}$, w1.: $4 \mathrm{~cm}$, th.: $0.8 \mathrm{~cm}, 0.3 \mathrm{~cm}, \mathrm{w} 2 .: 4.87 \mathrm{~g}$

12. Fragment of a socketed axe: Lower body fragment of a socketed axe. The casting seams are well-polished and the whole surface of the object is smooth. Traces of hammering and sharpening are visible along the blade. Minor casting fault (asymmetry) and porosity can be detected along the breakage surface. On the narrow body part, oval damage marks are visible. The object was probable bended to break which traces can be visible on the breakage surface (Fig. 50.12).

l.: $6.9 \mathrm{~cm}$, w1.: $5.6 \mathrm{~cm}$, th.: $0.7 \mathrm{~cm}, 0.3 \mathrm{~cm}, \mathrm{w} 2 .: 265.78 \mathrm{~g}$

13. Fragment of a socketed axe: Lower body fragment of a socketed axe. Remains of the original rib decoration and a rivet hole are visible on its frontal and narrow body parts. Minor asymmetry can be detected on the break surface. The casting seams are well-polished and the surface of the object is smooth. Trace of hammering and polishing can be observed along the blade (Fig. 50.13).

l.: $9 \mathrm{~cm}, \mathrm{w} 1 .: 5 \mathrm{~cm}, \mathrm{w} 2 .: 172.81 \mathrm{~g}, \mathrm{~d} 2$. of the socket: $5.3 \mathrm{~cm}$

14. Fragment of a socketed axe: Lower fragment of a socketed axe. Its body parts are shifted. Intensive porosity can be detected on the external surfaces and on the breakage surfaces as well (Fig. 51.14). l.: $6.2 \mathrm{~cm}, \mathrm{w} 1 .: 4.6 \mathrm{~cm}, \mathrm{w} 2 .: 164.07 \mathrm{~g}$

15. Fragment of a socketed axe: Upper part of a socketed axe with ribbed decoration (horizontal rib, V rib, Y rib, broken rib). Porosity can be observed along the breakage surfaces (Fig. 51.15).

1.: $2.2 \mathrm{~cm}$, w1.: $1.7 \mathrm{~cm}, \mathrm{w} 2 .: 7 \mathrm{~g}$

16. Fragment of a socketed axe: Fragment of a smaller socketed axe. Its body parts are slightly shifted and its casting seams were not polished completely. The surface is porous and it was damaged by corrosion (Fig. 51.16). 1.: $3.1 \mathrm{~cm}$, w1.: $1.8 \mathrm{~cm}$, th.: $1 \mathrm{~cm}, 0.7 \mathrm{~cm}, \mathrm{w} 2 .: 24 \mathrm{~g}$

17. Fragment of a socketed axe: Narrow body fragment of a socketed axe. Porosity is visible along the break surface (Fig. 51.17).

l.: $1.7 \mathrm{~cm}$, w1.: $1.5 \mathrm{~cm}$, th.: $0.6 \mathrm{~cm}, \mathrm{w} 2 .: 3 \mathrm{~g}$

18. Socketed chisel: Round-sectioned chisel with thickened mouth and conical short socket. Its blade is straight. The artefact is intact and no traces of casting fault can be observed along its surfaces. However, traces of corrosion damage occur on the section of the blade (Fig. 52.18).

l.: $12.1 \mathrm{~cm}, \mathrm{w} 1 .: 3.6 \mathrm{~cm}, \mathrm{w} 2 .: 141,47 \mathrm{~g}$, w1. of the blade.: $1 \mathrm{~cm}$

19. Fragment of a flange-handled sickle: Small fragment of a flange-handled sickle with ribs. Its broken edges are bent. No trace of casting fault can be observed along its breakage surfaces (Fig. 52.19).

l.: $3.7 \mathrm{~cm}$, w1.: $3.1 \mathrm{~cm}$, th.: $0.6 \mathrm{~cm}$, w2.: $25 \mathrm{~g}$

20. Fragment of a flange-handled sickle: Flange-handle fragment of a sickle. No traces of casting fault can be observed along its breakage surfaces (Fig. 52.20).

l.: $4.6 \mathrm{~cm}$, w1.: $3 \mathrm{~cm}$, th.: $0.3 \mathrm{~cm}$, w2.: $23 \mathrm{~g}$

21. Passementerie fibulae (A3a-Type): Fragmented A3a-Type passementerie fibulae. Its pin, lead-spiral and four side-spirals are missing. The object is composed of circle-sectioned wires which are fastened by tree, casted oval hinges. The central wire is eight-shaped before the spring. Traces of casting faults and hammering are visible on the surface of the hinges (Fig. 53.21).

1.: $11.8 \mathrm{~cm}, \mathrm{w} 1 .: 5.5 \mathrm{~cm}, \mathrm{~d}$. of the side-spirals.: $2.3 \mathrm{~cm}$, l. of the hinges.: $1.6 \mathrm{~cm}-1.8 \mathrm{~cm}-1.5 \mathrm{~cm}$, th. of the wire: $0.2 \mathrm{~cm}$, w2: $42.67 \mathrm{~g}$

22. Passementerie fibulae (Group C, Uzsavölgy-Type): Fragment of an Uzsavölgy-Type passementerie fibulae in three parts. The current state of the object is probable the result of post-depositional damages. It composes of circle-sectioned wires which are fastened by a bended sheet hinge. The central wire is eight shaped before the spring. The remains of the typical wire frame are also visible (Fig. 53.22a-b).

1.: $7.3 \mathrm{~cm}, \mathrm{w} 1 .: 5.7 \mathrm{~cm}, \mathrm{~d}$. of the $22 \mathrm{~b}$ side spiral: $3.4 \mathrm{~cm}$, l. of the hinge.: $1.7 \mathrm{~cm}$, d. of the wire.: $0.2 \mathrm{~cm}, \mathrm{w} 2 .:$ $21.97 \mathrm{~g}$, d. of the side spiral.: $3.4 \mathrm{~cm}$, th. of the wire.: $0.2 \mathrm{~cm}, \mathrm{w} 2 .: 12.45 \mathrm{~g}$ 


\section{Undecorated sheet belt}

23.1: End fragment of an undecorated belt. The horizontal cracks on the edges were repaired by small metal sheet wires which were pulled over holes. Both the inner and the external surface of the object is intensively corroded (Fig. 54, Fig. 55.23.1).

l.: $16 \mathrm{~cm}$, w1.: $3.9 \mathrm{~cm}$, th.: $1 \mathrm{~mm}, \mathrm{w} 2 .: 27.32 \mathrm{~g}$

23.2: Slightly bended belt fragment. Traces of corrosion damage can be observed on its surfaces. A small, perforated hole is visible on the middle of the fragment (Fig. 54, Fig. 55.23.2).

l.: $13.2 \mathrm{~cm}$, w1.: $4 \mathrm{~cm}$, th.: $1 \mathrm{~mm}$, w2: $15.62 \mathrm{~g}$

23.3: Slightly bended belt fragment. Traces of intensive corrosion damage can be observed on its surfaces (Fig. 56.23.3).

l.: $11.8 \mathrm{~cm}$, w1.: $4 \mathrm{~cm}$, th.: $1 \mathrm{~mm}$, w2.: $12.32 \mathrm{~g}$

23.4: Slightly bended belt fragment. Traces of intensive corrosion damage can be observed on its surfaces (Fig. 56.23.4).

1.: $14.1 \mathrm{~cm}, \mathrm{w} 1 .: 3.9$; th.: $1 \mathrm{~mm}, \mathrm{w} 2 .: 11.77 \mathrm{~g}$

24. Fragment of a torques: Thin fragment of a circular-sectioned torques with rolled-terminals. The object was bent into circle and its pattern is composed of 16 bundles of lines (Fig. 57.24).

1.: $6 \mathrm{~cm}, \mathrm{w} 1 .: 5.9 \mathrm{~cm}$, th.: $0.3 \mathrm{~cm}, \mathrm{w} 2 .: 13 \mathrm{~g}$

25. Fragment of a torques: Fragment of a circular-sectioned torques with rolled-terminals. The object was bent into circle and it is decorated with pseudo-torsion (Fig. 57.25).

1.: $5 \mathrm{~cm}$, w1.: $4.5 \mathrm{~cm}$, th.: $0.3 \mathrm{~cm}, \mathrm{w} 2 .: 22 \mathrm{~g}$

26. Fragment of a torques: Fragment of a circular-sectioned torques with rolled-terminals. The object was bent into circle and it is decorated with torsion (Fig. 57.26).

1.: $5.5 \mathrm{~cm}$, w1.: $5 \mathrm{~cm}$, th.: $0.4 \mathrm{~cm}, \mathrm{~S} .: 20 \mathrm{~g}$

27. Ring: Circular-sectioned, opened ring with rounded terminals. Due to the corrosion damage the original patterns cannot be observed fully, however fine bundles of lines (6-12-4-3-8-6-3-12-11-6) can be seen on its external surface. The object is slightly bended (Fig. 58.27).

th.: $0.4 \mathrm{~cm}$, o.l.: $37 \mathrm{~cm}, \mathrm{~d} .: 12.7 \mathrm{~cm}, \mathrm{w} 2 .: 31.13 \mathrm{~g}$

28. Ring: Opened semicircle-sectioned ring with pointed-terminals (Fig.59.28).

th.: $0.3 \mathrm{~cm}$, o. $1 .: 32.3 \mathrm{~cm}, \mathrm{~d} .: 9.8 \mathrm{~cm}, \mathrm{w} 2 .: 26.22 \mathrm{~g}$

29. Ring: Opened semicircle-sectioned ring with pointed-terminals (Fig. 59.29). One of its terminals is unfolded. th.: $0.3-0.4 \mathrm{~cm}$, o. $1 .: 30.2 \mathrm{~cm}$, d.: $9.7 \mathrm{~cm}$, w2.: $18.81 \mathrm{~g}$

30. Ring: Opened quadratic-sectioned ring with pointed-terminals (Fig. 59.30).

th.: $0.4 \mathrm{~cm}$, o. $1 .: 26.9 \mathrm{~cm}$, d.: $9.7 \mathrm{~cm}$, w2.: $25.28 \mathrm{~g}$

31. Ring: Opened semicircle-sectioned ring with overlapping pointed-terminals (Fig. 59.31). th.: $0.4 \mathrm{~cm}$, o. $1 .: 33.1 \mathrm{~cm}, \mathrm{~d} .: 9.2 \mathrm{~cm}, \mathrm{w} 2 .: 41.81 \mathrm{~g}$

32. Ring: Opened quadratic-sectioned ring with pointed-terminals. The objects terminals are twisted (Fig. 59.32). th.: $0.5 \mathrm{~cm}$, o. $1 .: 32.3 \mathrm{~cm}$, d.: $9.5 \mathrm{~cm}$, w2.: $38.94 \mathrm{~g}$

33. Ring: Opened triangle-sectioned ring with overlapping pointed-terminals (Fig. 60.33). th.: $0.4 \mathrm{~cm}$, o. $1 .: 27.8 \mathrm{~cm}$, d.: $9 \mathrm{~cm}, \mathrm{w} 2 .: 14.15 \mathrm{~g}$

34. Ring: Opened oval-sectioned ring with pointed-terminals (Fig. 60.34). th.: $0.3 \mathrm{~cm}$, o. $1 .: 24.8 \mathrm{~cm}, \mathrm{~d} .: 8 \mathrm{~cm}, \mathrm{w} 2 .: 13.91 \mathrm{~g}$

35. Ring: Opened oval-sectioned ring with pointed-terminals (Fig. 60.35). th.: $0.4 \mathrm{~cm}$, o. $1 .: 21.9 \mathrm{~cm}$, d.: $7.5 \mathrm{~cm}$, w2.: $21.23 \mathrm{~g}$

36. Ring: Opened quadratic-sectioned ring with overlapping pointed-terminals (Fig. 60.36). th.: $0.4 \mathrm{~cm}$, o. $1 .: 23.7 \mathrm{~cm}$, d.: $7 \mathrm{~cm}$, w2.: $22.34 \mathrm{~g}$

37. Ring: Opened semicircle-sectioned ring with pointed- and flattened-terminals (Fig. 60.37). th.: $0.5 \mathrm{~cm}$, o. $1 .: 8.2 \mathrm{~cm}, \mathrm{~d} .: 6.5 \mathrm{~cm}, \mathrm{w} 2 .: 16.24 \mathrm{~g}$

38. Ring: Opened oval-sectioned ring with overlapping pointed-terminals (Fig. 60.38). th.: $0.4 \mathrm{~cm}$, o. $1 .: 19.5 \mathrm{~cm}$, d.: $6 \mathrm{~cm}, \mathrm{w} 2 .: 13.54 \mathrm{~g}$

39. Ring: Opened quadratic-sectioned ring with overlapping pointed-terminals (Fig. 61.39). th.: $0.4 \mathrm{~cm}$, o. $1 .: 20 \mathrm{~cm}$, d.: $5.9 \mathrm{~cm}, \mathrm{w} 2 .: 11.69 \mathrm{~g}$

40. Ring: Opened semicircle-sectioned ring with overlapping pointed-terminals (Fig. 61.40). th.: $0.3 \mathrm{~cm}$, o. $1 .: 17 \mathrm{~cm}, \mathrm{~d} .: 4.9 \mathrm{~cm}, \mathrm{w} 2 .: 7.20 \mathrm{~g}$ 
41. Ring: Opened oval-sectioned ring with overlapping pointed-terminals (Fig. 61.41). th.: $0.4 \mathrm{~cm}$, o. $1 .: 16.4 \mathrm{~cm}$, d.: $4.3 \mathrm{~cm}$, w2.: $17.83 \mathrm{~g}$

42. Ring: Opened oval-sectioned ring with overlapping pointed-terminals (Fig. 61.42). th.: $0.3-0.4 \mathrm{~cm}$, o. $1 .: 21 \mathrm{~cm}, \mathrm{~d} .: 4.5 \mathrm{~cm}, \mathrm{w} 2 .: 19.37 \mathrm{~g}$

43. Ring: Opened oval-sectioned ring with overlapping pointed-terminals (Fig. 61.43). th.: $0.4 \mathrm{~cm}$, o. $1 .: 22 \mathrm{~cm}, \mathrm{~d} .: 4.7 \mathrm{~cm}$, w2.: $17.95 \mathrm{~g}$

44. Ring: Opened quadratic-sectioned ring with overlapping pointed-terminals (Fig. 61.44). th.: $0.4 \mathrm{~cm}$, o. $1 .: 15.8 \mathrm{~m}$, d.: $3.9 \mathrm{~cm}$, w2.: $10.03 \mathrm{~g}$

45. Ring: Opened oval-sectioned ring with pointed-terminals in two fragments (Fig. 61.45). th.: $0.3 \mathrm{~cm}$, o. $1 .: 18 \mathrm{~cm}$, d.: $7.9 \mathrm{~cm}$, w2.: $6.16 \mathrm{~g}$

46. Fragmented ring: Opened oval-sectioned ring with overlapping pointed-terminals. One of its terminals is broken (Fig. 62.46). th.: $0.5 \mathrm{~cm}$, o. $1 .: 26.5 \mathrm{~cm}$, d.: $7.5 \mathrm{~cm}$, w2.: $22.11 \mathrm{~g}$

47. Fragmented ring: Semicircle-sectioned ring with pointed-terminals. One of its terminals is broken the other is fragmented (Fig. 62.47).

th.: $0.3 \mathrm{~cm}$, o. $1 .: 17.4 \mathrm{~cm}$, d.: $6.9 \mathrm{~cm}, \mathrm{w} 2 .: 9.62 \mathrm{~g}$

48. Fragmented ring: Oval-sectioned ring with pointed-terminals. One of its terminals is broken (Fig. 62.48). th.: $0.5 \mathrm{~cm}$, o. $1 .: 19 \mathrm{~cm}, \mathrm{~d} .: 7 \mathrm{~cm}, \mathrm{w} 2 .: 20.11 \mathrm{~g}$

49. Fragmented ring: Circle-sectioned ring with pointed-terminals. One of its terminals is broken (Fig. 62.49). th.: $0.4 \mathrm{~cm}$, o. $1 .: 18 \mathrm{~cm}, \mathrm{~d} .: 8.4 \mathrm{~cm}, \mathrm{w} 2 .: 16.01 \mathrm{~g}$

50. Fragmented ring: Semicircle-sectioned ring with pointed-terminals. One of its terminals is broken (Fig. 62.50). th.: $0.6 \mathrm{~cm}$, o. $1 .: 21 \mathrm{~cm}, \mathrm{~d} .: 8 \mathrm{~cm}, \mathrm{w} 2 .: 34.31 \mathrm{~g}$

51. Fragmented ring: Quadratic-sectioned ring with pointed-terminals. One of its terminals is broken (Fig. 62.51). th.: $0.4 \mathrm{~cm}$, o. $1 .: 18.5 \mathrm{~cm}$, d.: $6 \mathrm{~cm}$, w2.: $11.64 \mathrm{~g}$

52. Fragmented ring: Oval-sectioned ring with pointed terminals. One of its terminals is broken (Fig. 63.52). th.: $0.4 \mathrm{~cm}$, o. $1 .: 21.2 \mathrm{~cm}$, d.: $6.7 \mathrm{~cm}, \mathrm{w} 2 .: 27.74 \mathrm{~g}$

53. Fragmented ring: Circle-sectioned ring with pointed terminals. One of its terminals is broken (Fig. 63.53). th.: $0.4 \mathrm{~cm}$, o. $1 .: 19.3 \mathrm{~cm}$, d.: $7.3 \mathrm{~cm}$, w2.: $21.13 \mathrm{~g}$

54. Fragmented ring: Trapezoid-sectioned ring with pointed-terminals. One of its terminals is bended and broken (Fig. 63.54). th.: $0.4 \mathrm{~cm}$, o. $1 .: 20.5 \mathrm{~cm}, \mathrm{~d} .: 6.3 \mathrm{~cm}, \mathrm{w} 2 .: 26.17 \mathrm{~g}$

55. Fragmented ring: Oval-sectioned ring with overlapping pointed-terminals. One of its terminals is broken (Fig. 63.55).

th.: $0.4 \mathrm{~cm}$, o. $1 .: 24.8 \mathrm{~cm}$, d.: $7.8 \mathrm{~cm}$, w2.: $28.95 \mathrm{~g}$

56. Fragmented ring: Semicircle-sectioned ring with pointed terminals. One of its terminals is broken (Fig. 63.56). th.: $0.5 \mathrm{~cm}$, o. $1 .: 18.5 \mathrm{~cm}$, d.: $6.7 \mathrm{~cm}, \mathrm{w} 2 .: 12.71 \mathrm{~g}$

57. Fragment of a ring: Quadratic-sectioned ring with pointed terminals. One of its terminals is broken (Fig. 63.57). th.: $0.5 \mathrm{~cm}$, o. $1 .: 15.7 \mathrm{~cm}$, d.: $8.4 \mathrm{~cm}$, w2.: $16.29 \mathrm{~g}$

58. Fragment of a ring: Fragment of a circle-sectioned ring with pointed terminals. One of its terminals is broken (Fig. 63.58).

th.: $0.6 \mathrm{~cm}$, o. $1 .: 14.2 \mathrm{~cm}$, d.: $8 \mathrm{~cm}$, w2.: $20.94 \mathrm{~g}$

59. Fragment of a ring: Fragment of a semicircle-sectioned ring with pointed terminals. One of its terminals is broken (Fig. 64.59).

th.: $0.6 \mathrm{~cm}$, o. $1 .: 17.2 \mathrm{~cm}$, d.: $9.5 \mathrm{~cm}$, w2.: $36.68 \mathrm{~g}$

60. Fragment of a ring: Fragment of an oval-sectioned ring with pointed terminals. One of its terminals is broken (Fig. 64.60).

th.: $0.4 \mathrm{~cm}$, o. $1 .: 10.6 \mathrm{~cm}$, d.: $5.5 \mathrm{~cm}, \mathrm{w} 2 .: 11.59 \mathrm{~g}$

61. Fragment of a ring: Fragment of an oval-sectioned ring with pointed terminals (Fig. 64.61). th.: $0.6 \mathrm{~cm}$, o. $1 .: 14.4 \mathrm{~cm}, \mathrm{~d} .: 9.7 \mathrm{~cm}, \mathrm{w} 2 .: 22.4 \mathrm{~g}$

62. Fragment of a ring: Small fragment of an oval-sectioned ring with pointed terminals. One of its terminals is broken (Fig. 64.62).

th.: $0.3 \mathrm{~cm}$, o. $1 .: 8.3 \mathrm{~cm}$, d.: $5 \mathrm{~cm}$, w2.: $5.4 \mathrm{~g}$ 
63. Fragment of a ring: Fragment of a circle-sectioned ring with pointed terminals. Its bended state might be the result of a deliberate bending (Fig. 64.63). th.: $0.5 \mathrm{~cm}$, o. $1 .: 9.3 \mathrm{~cm}, \mathrm{~d} .: 8 \mathrm{~cm}, \mathrm{w} 2 .: 8.86 \mathrm{~g}$

64. Fragment of a ring: Fragment of a semi-circle sectioned ring (Fig. 64.64). th.: $0.5 \mathrm{~cm}$, o. $1 .: 8.5 \mathrm{~cm}, \mathrm{~d} .: 7 \mathrm{~cm}, \mathrm{w} 2 .: 12.71 \mathrm{~g}$

65. Fragment of a ring: Fragment of an oval-sectioned ring (Fig. 64.65). th.: $0.5 \mathrm{~cm}$, o. $1 .: 5.5 \mathrm{~cm}, \mathrm{w} 2 .: 8.33 \mathrm{~g}$

66. Fagment of a ring: Fragment of a rhomboid-sectioned ring with pointed-terminals. Its surface is smooth, however porosity is visible along its breakage surface. In addition, its casted parts are shifted due to the imprecise positioning of the bivalve mould (Fig. 64.66).

l.: $5 \mathrm{~cm}$, w1.: $4.5 \mathrm{~cm}$, th.: $0.8 \mathrm{~cm}$, w2.: $10 \mathrm{~g}$

67. Fragment of a ring: Fragment of a flattened rhomboid-sectioned ring (Fig. 64.67). l.: $5.4 \mathrm{~cm}$, w1.: $1.8 \mathrm{~cm}$, th.: $0.4 \mathrm{~cm}, \mathrm{w} 2 .: 10 \mathrm{~g}$

68. "Chained-objects": The artefacts composed of seven different objects. A closed ring is situated in its center, on which the other five opened rings and a wire are bent (Fig. 64.68). l.: $9.2 \mathrm{~cm}, \mathrm{w} 1 .: 4 \mathrm{~cm}, \mathrm{w} 2: 601 \mathrm{~g}$

69. Metal sheet tube: Thin metal sheet folded into a tube. The object is decorated with incised bundles of lines (5-7-5). Its surface is slightly corroded (Fig. 65.69). l.: $4.6 \mathrm{~cm}$, w1.: $1.1 \mathrm{~cm}$, o. $1 .: 2.4 \mathrm{~cm} \times 4.6 \mathrm{~cm}$, th.: $0.1 \mathrm{~cm}, \mathrm{w} 2 .: 3 \mathrm{~g}$

70. Metal sheet tube: Thin metal sheet folded into a tube. The object is decorated with incised bundles of lines (5-6-6). Its surface is slightly corroded (Fig. 65.70).

1.: $4.7 \mathrm{~cm}$, w1.: $1.1 \mathrm{~cm}$, o. $1 .: 2.3 \mathrm{~cm} \times 4.7 \mathrm{~cm}$, th.: $0.1 \mathrm{~cm}, \mathrm{w} 2 .: 3 \mathrm{~g}$

71. Metal sheet tube: Thin metal sheet folded into a tube. The object is decorated with incised bundles of lines (5-7-7). Its surface is slightly corroded (Fig. 65.71).

l.: $4.7 \mathrm{~cm}, \mathrm{w} 1 .: 1 \mathrm{~cm}$, o. $1 .: 2.4 \mathrm{~cm}$, th.: $0.1 \mathrm{~cm}, \mathrm{w} 2 .: 2 \mathrm{~g}$

72. Metal sheet tube: Thin metal sheet folded into a tube. The object is decorated with incised bundles of lines (5-5-5). Its surface is slightly corroded (Fig. 65.72).

l.: $4.3 \mathrm{~cm}$, w1.: $1.6 \mathrm{~cm}$, o. $1 .: 3.4 \mathrm{~cm}$, th.: $0.1 \mathrm{~cm}, \mathrm{w} 2 .: 4 \mathrm{~g}$

73. Metal sheet tube: Thin metal sheet folded into a tube. The object is decorated with incised bundles of lines (6). Its surface is slightly corroded (Fig. 65.73).

l.: $2.2 \mathrm{~cm}$, w1.: $0.8 \mathrm{~cm}$, o. $1 .: 2.3 \mathrm{~cm}$, th.: $0.1 \mathrm{~cm}, \mathrm{w} 2: .0 .5 \mathrm{~g}$

74. Metal sheet tube: Thin metal sheet folded into a tube. The object is decorated with incised bundles of lines (4-6-6). Its surface is slightly corroded. Its surface is slightly corroded (Fig. 65.74).

1.: $3.9 \mathrm{~cm}$, w1.: $1.5 \mathrm{~cm}$, o. $1 .: 2.5 \mathrm{~cm} \times 3.9 \mathrm{~cm}$, th.: $0.1 \mathrm{~cm}, \mathrm{w} 2 .: 2 \mathrm{~g}$

75. Metal sheet tube: Thin metal sheet folded into a tube. It decorated with bundles of lines (6) (Fig. 65.75). l.: $3.2 \mathrm{~cm}$, w1.: $1.4 \mathrm{~cm}$, o. $1 .: 3.2 \mathrm{~cm}$, th.: $0.1 \mathrm{~cm}, \mathrm{w} 2 .: 1 \mathrm{~g}$

76. Metal sheet tube: Thin metal sheet folded into a tube. The object is decorated with lines of dots (5). Due to the corrosion damage only small parts of the decoration can be observed (Fig. 65.76).

l.: $2.3 \mathrm{~cm}$, w1.: $1.9 \mathrm{~cm}$, o. $1 .: 3.6 \mathrm{~cm}$, th.: $0.1 \mathrm{~cm}, \mathrm{w} 2 .: 2 \mathrm{~g}$

77. Fragments of a Žatec-Type bucket: Seventeen fragments of a metal sheet object, probable Žatec-Type bucket. Its decoration composed of embossed parallel ribs and dots. The edge of the fragment is wavy. Based on its parallels, the objects can be reconstructed in two different ways (Fig. 66.77.1-77.17).

77.1. $1 .: 4.7 \mathrm{~cm}$, w1.: $4.4 \mathrm{~cm}$, th.: $0.1 \mathrm{~cm}$, w2.: $1.84 \mathrm{~g}$ 77.2. 1.: $3.2 \mathrm{~cm}$, w1.: $2.7 \mathrm{~cm}$, th.: $0.1 \mathrm{~cm}, \mathrm{w} 2 .: 1.04 \mathrm{~g}$ 77.3. $1 .: 3.2 \mathrm{~cm}, \mathrm{w} 1 .: 2.7 \mathrm{~cm}$, th.: $0.1 \mathrm{~cm}, \mathrm{w} 2 .: 1.79 \mathrm{~g}$ 77.4. $1 .: 5.5 \mathrm{~cm}$, w1.: $2.9 \mathrm{~cm}$, th.: $0.1 \mathrm{~cm}$, w2.: $0.79 \mathrm{~g}$ 77.5. $1 .: 4 \mathrm{~cm}$, w1.: $2.6 \mathrm{~cm}$, th.: $0.1 \mathrm{~cm}, \mathrm{w} 2 .: 1.05 \mathrm{~g}$ 77.6. $1 .: 7.1 \mathrm{~cm}, \mathrm{w} 1 .: 6 \mathrm{~cm}$, th.: $0.1 \mathrm{~cm}, \mathrm{w} 2 .: 3.12 \mathrm{~g}$ 77.7. $1 .: 4 \mathrm{~cm}$, w1.: $2.4 \mathrm{~cm}$, th.: $0.1 \mathrm{~cm}, \mathrm{w} 2 .: 1.17 \mathrm{~g}$ 77.8. $1 .: 3.7 \mathrm{~cm}$, w1.: $2.6 \mathrm{~cm}$, th.: $0.1 \mathrm{~cm}, \mathrm{w} 2 .: 1.16 \mathrm{~g}$ 77.9. $1 .: 2.4 \mathrm{~cm}, \mathrm{w} 1 .: 1.6 \mathrm{~cm}$, th.: $0.1 \mathrm{~cm}, \mathrm{w} 2 .: 0.38 \mathrm{~g}$ 77.10. $1 .: 2.3 \mathrm{~cm}, w 1 .: 2.1 \mathrm{~cm}$, th.: $0.1 \mathrm{~cm}, \mathrm{w} 2 .: 0.66 \mathrm{~g}$ 77.11. $1 .: 3.2 \mathrm{~cm}$, w1.: $1.6 \mathrm{~cm}$, th.: $0.1 \mathrm{~cm}$, w2:: $0.58 \mathrm{~g}$ 77.12. $1 .: 3 \mathrm{~cm}$, w1.: $1.3 \mathrm{~cm}$, th.: $0.1 \mathrm{~cm}$, w2.: $0.58 \mathrm{~g}$ 77.13. $1 .: 1.7 \mathrm{~cm}, \mathrm{w} 1 .: 0.9 \mathrm{~cm}$, th.: $0.1 \mathrm{~cm}, \mathrm{w} 2 .: 0.26 \mathrm{~g}$ 77.14. $1 .: 2.1 \mathrm{~cm}$, w1.: $0.4 \mathrm{~cm}$, th.: $0.1 \mathrm{~cm}$, w2.: $0.25 \mathrm{~g}$ 77.15. $1 .: 1 \mathrm{~cm}$, w1.: $0.5 \mathrm{~cm}$, th.: $0.1 \mathrm{~cm}$, w2.: $0.8 \mathrm{~g}$ 77.16. $1 .: 0.6 \mathrm{~cm}$, w1.: $0.6 \mathrm{~cm}$, th.: $0.1 \mathrm{~cm}$, w2.: $0.1 \mathrm{~g}$ 77.17. $1 .: 0.5 \mathrm{~cm}$, w1.: $0.5 \mathrm{~cm}$, th.: $0.1 \mathrm{~cm}, \mathrm{w} 2 .: 0.1 \mathrm{~g}$ 
78. Fragment of an axe-half form: Fragment of an axe half-form with thickened mouth. Intensive corrosion can be detected on its surface. The upper part of the object is slightly porous (Fig. 67.78). 1.: $15.3 \mathrm{~cm}$, w1.: $4.3 \mathrm{~cm}$, th.: $1.7 \mathrm{~cm}, \mathrm{w} 2 .: 308 \mathrm{~g}$

79. Fragment of a rod ingot: Semi-circle sectioned rod ingot. Its breakage surface is porous in one spot (Fig. 67.79). l.: $5.2 \mathrm{~cm}$, w1.: $1 \mathrm{~cm}$, th.: $1 \mathrm{~cm}, \mathrm{w} 2 .: 26 \mathrm{~g}$

80. Fragment of a plano-convex ingot: Half fragment of a larger plano-convex ingot. Porosity is intensive on its both flat and convex sides. Crater like traces of gas bubble are visible on its breakage surface. A recasted wire ring can be detected on its convex side (Fig. 68.80). l.: $20.3 \mathrm{~cm}$, w1.: $15.8 \mathrm{~cm}$, h.: $3.5 \mathrm{~cm}$, w2.: $3077 \mathrm{~g}$

81 Fragment of a plano-convex ingot: Quarter fragment of a larger plano-convex ingot. Trace of slight porosity visible on its external surface (Fig. 69.81).

l.: $13.5 \mathrm{~cm}$, w1.: $12.5 \mathrm{~cm}$, h.: $6.3 \mathrm{~cm}$, w2.: $2231 \mathrm{~g}$

82. Fragment of a plano-convex ingot: Quarter fragment of a plano-convex ingot. Its external surface is slightly- but its breakage surface is intensively porous. Layered casting also can be detected along its breakage surface (Fig. 70.82).

l.: $10.2 \mathrm{~cm}$, w1.: $9 \mathrm{~cm}$, h.: $3.7 \mathrm{~cm}, \mathrm{w} 2 .: 594 \mathrm{~g}$

83. Fragment of a plano-convex ingot: Greater fragment of a plano-convex ingot with traces of porosity on its surfaces. Layered casting can also be detected on its breakage surface (Fig. 70.83).

1.: $7.6 \mathrm{~cm}$, w1.: $6.6 \mathrm{~cm}, \mathrm{~h} .: 4.2 \mathrm{~cm}$, w2.: $595 \mathrm{~g}$

84. Fragment of a plano-convex ingot: Small, flat fragment of a plano-convex ingot without traces of porosity (Fig. 71.84).

l.: $11.6 \mathrm{~cm}$, w1.: $10.3 \mathrm{~cm}$, h.: $1.2 \mathrm{~cm}$, w2.: $390 \mathrm{~g}$

85. Fragments of a plano-convex ingot: Great fragment of a flat plano-convex ingot. Porosity can be observed on its surface. The central part of the ingot is missing however No. 85.1 could have originally be a part of this section. Based on its breakage surface the object might be casted layered (Fig. 72.85).

Overall dimensions: $1 .: 15.1$, w1.: $8.8 \mathrm{~cm}$, h.: $0.6 \mathrm{~cm}(2.3 \mathrm{~cm}$ with the 85.1. fragment), w2.: $880 \mathrm{~g}$ 85.1. 1.: $8.6 \mathrm{~cm}$, w1.: $4.7 \mathrm{~cm}$, h.: $2.3 \mathrm{~cm}$, w2.: $172 \mathrm{~g}$

86. Fragment of a plano-convex ingot: Edge fragment of a greater plano-convex ingot with minor porosity (Fig. 73.86).

l.: $7 \mathrm{~cm}, \mathrm{w} 1 .: 4.5 \mathrm{~cm}, \mathrm{~h} .: 2.5 \mathrm{~cm}, \mathrm{w} 2 .: 236 \mathrm{~g}$

87. Fragment of a plano-convex ingot: Fragment of a greater plano-convex ingot with minor porosity (Fig. 73.87). l.: $5.2 \mathrm{~cm}$, w1.: $4.2 \mathrm{~cm}$, h.: $3 \mathrm{~cm}, \mathrm{w} 2 .: 134 \mathrm{~g}$

88. Fragment of a plano-convex ingot: Small edge fragment of a plano-convex ingot. Its breakage- and external surface is porous. In addition, traces of layered casting are also visible along the breakage surface (Fig. 73.88). l.: $5.5 \mathrm{~cm}, \mathrm{w} 1 .: 4.5 \mathrm{~cm}, \mathrm{~h} .: 1.8 \mathrm{~cm}, \mathrm{w} 2 .: 95 \mathrm{~g}$

89. Fragment of a plano-convex ingot: Small fragment of a plano-convex ingot (Fig. 74.89). 1.: $2.8 \mathrm{~cm}, \mathrm{w} 1 .: 3 \mathrm{~cm}, \mathrm{~h} .: 1.3 \mathrm{~cm}, \mathrm{w} 2 .: 3.9 \mathrm{~g}$

90. Fragment of a plano-convex ingot: Small fragment of a plano-convex ingot. Its breakage- and external surfaces are porous. Layered casting can be observed along its breakage surface (Fig.74.90). l.: $4.5 \mathrm{~cm}$, w1.: $3.2 \mathrm{~cm}$, h.: $1.7 \mathrm{~cm}, \mathrm{w} 2: 58 \mathrm{~g}$

91. Fragment of a plano-convex ingot: Amorphous fragment of a plano-convex ingot (Fig. 74.91). 1.: $3.6 \mathrm{~cm}$, w1.: $2.8 \mathrm{~cm}$, h.: $2.2 \mathrm{~cm}$, w2.: $69 \mathrm{~g}$

92. Fragment of a plano-convex ingot: Fragment of a flat plano-convex ingot (Fig. 74.92). 1.: $3.2 \mathrm{~cm}, \mathrm{w} 1 .: 3.6 \mathrm{~cm}, \mathrm{~h} .: 0.7 \mathrm{~cm}, \mathrm{w} 2 .: 20 \mathrm{~g}$

93. Fragment of a plano-convex ingot: Small fragment of a flat plano-convex ingot. Layered casting is visible on its breakage surface (Fig. 74.93).

1.: $3.2 \mathrm{~cm}, \mathrm{w} 1 .: 2.1 \mathrm{~cm}, \mathrm{~h} .: 0.8 \mathrm{~cm}, \mathrm{w} 2 .: 14 \mathrm{~g}$

94. Fragment of a plano-convex ingot: Small fragment of a plano-convex ingot. The structure of its breakage surface is porous (Fig.74.94).

1.: $3 \mathrm{~cm}$, w1.: $2 \mathrm{~cm}$, h.: $0.7 \mathrm{~cm}$, w2.: 0.6

95. Tube with widened rim: Round-sectioned tube with widened rim. Slight asymmetry can be observed on its upper part. The surface of the object is smooth, however a long vertical hole are visible on the shaft which could be associated with fault casting (Fig. 75.95).

1.: $6 \mathrm{~cm}, \mathrm{w} 1 .: 3.3 \mathrm{~cm}, \mathrm{w} 2 .: 37 \mathrm{~g}$ 
96. Casting jet: Broken casting jet with the remains of the casted object. Its casting seams are unpolished (Fig. 75.96).

l.: $7.6 \mathrm{~cm}, \mathrm{w} 1 .: 4.6 \mathrm{~cm}$, th.: $0.9 \mathrm{~cm}, \mathrm{w} 2 .: 36 \mathrm{~g}$

97. Casting jet: Small conical-shaped casting jet (Fig. 76.97).

1.: $4.5 \mathrm{~cm}$, w1.: $2.3 \mathrm{~cm}$, th.: $0.9-0.2 \mathrm{~cm}$, w2.: $18 \mathrm{~g}$

98. Wire fragment: Thin, folded fragment of a quadratic-sectioned wire (Fig. 76.98).

o. $1 .: 9.3 \mathrm{~cm}, \mathrm{w} 2 .: 0.5 \mathrm{~g}$

99. Wire fragment: Thin, folded fragment of a quadratic-sectioned wire (Fig. 76.99).

o. $1 .: 13.3 \mathrm{~cm}, \mathrm{w} 2 .: 0.8 \mathrm{~g}$

100. Wire fragment: Thin, folded fragment of a quadratic-sectioned wire (Fig. 76.100). o. $1 .: 6.2 \mathrm{~cm}, \mathrm{w} 2 .: 0.4 \mathrm{~g}$

101. Fragment of a socketed utensil: Side fragment of a socketed utensil. Its surface is well-polished (Fig. 76.101). l.: $3.6 \mathrm{~cm}$, w1.: $1.5 \mathrm{~cm}$, th.: $0.1 \mathrm{~cm}, \mathrm{w} 2 .: 7 \mathrm{~g}$

102. Fragment of a socketed utensil: Edge fragment of a socketed utensil. Its surface is polished, no traces of casting faults can be observed along its breakage surfaces (Fig. 76.102).

l.: $2.5 \mathrm{~cm}$, w1.: $1.9 \mathrm{~cm}$, th.: $0.2 \mathrm{~cm}$, w2.: $6 \mathrm{~g}$

103. Mouth fragment of a socketed utensil: Fragment of a large utensil, possible socketed axe. Its surface is well-polished and no traces of casting fault can be observed on them (Fig. 76.103).

1.: $3 \mathrm{~cm}, \mathrm{w} 1 .: 2.2 \mathrm{~cm}$, th.: $0.3 \mathrm{~cm}, \mathrm{w} 2 .: 11 \mathrm{~g}$

104. Fragment of a socketed utensil (Fig. 76.104).

l.: $1.5 \mathrm{~cm}, \mathrm{w} 1 .: 1.1 \mathrm{~cm}$, th.: $0.2 \mathrm{~cm}, \mathrm{w} 2 .: 1.5 \mathrm{~g}$

105. Fragment of a socketed utensil (Fig. 76.105).

1.: $1.5 \mathrm{~cm}$, w1.: $1.7 \mathrm{~cm}$, th.: $0.2 \mathrm{~cm}$, w2.: $1 \mathrm{~g}$

106. Fragment of a socketed utensil (Fig. 76.106).

l.: $0.7 \mathrm{~cm}, \mathrm{w} 1 .: 0.4 \mathrm{~cm}$, th.: $0.2 \mathrm{~cm}, \mathrm{w} 2 .: 0.5 \mathrm{~g}$

107. Unclassifiable object (belt hook or button): Small casted object with hook. Casting faults are visible on its external surface (Fig. 76.107).

l.: $2.2 \mathrm{~cm}, \mathrm{w} 1 .: 1.8 \mathrm{~cm}, \mathrm{w} 2 .: 12 \mathrm{~g}$

\section{Stray find from Kesztölc}

Crescent-shaped objects: Small, crescent-shaped object broken into two parts. Its body is pierced in three sections (Fig. 2).

l.: $8 \mathrm{~cm}, \mathrm{w} 1 .: 2.5 \mathrm{~cm}$, th.: $0.5 \mathrm{~cm}, \mathrm{w} 2 .: 33 \mathrm{~g}$ 


\section{References}

Aldea, I. - Ciugudean, H. 1995: Der dritte hallstattzeitliche Depotfund von Vinţu de Jos, Kr. Alba, Siebenbürgen. In: Soroceanu, T. (Hrsg.): Bronzefunde aus Rumänien. Prähistorische Archäologie in Südosteuropa 10. Berlin, 212-223.

Anderson, K. 2011: Slashing and thrusting with Late Bronze Age spears: analysis and experiment. Antiquity 85, 599-612.

Angeli, W. - Neuninger, H. 1964: Ein urnenfelderzeitliche Depotfund aus der Gegend des Plattensees. Mitteilungen der Anthropologischen Gesellschaft zu Wien 93-94, 77-89.

Avila, R. A. J. 1983: Bronze Lanzen- und Pfeilspitzen der griechisen Spätbronzezeit. Prähistorische Bronzefunde 5/1. München.

ÅBerg, N. 1935: Bronzezeitliche und Früheisenzeitliche Chronologie V. Stockholm.

BADER, T. 1983: Die Fibeln in Rumänien. Prähistorische Bronzefunde 16/6. Stuttgart.

BADER, T. 2006: Lanzenspitzen - eine vernachlässigte Fundgattung. In: KoBAL' J. (Hrsg.): Bronzezeitlichen Depotfunde. Probleme der Interpretation. Materialien der Festkonferenz für Tivodor Lehoczky zum 175. Geburstag. Ushhorod, 5.-6. Oktober 2005 - Скарби доби бронзи - проблема інтерпретації - Матеріали Конференції присвяченої 175-річчю від дня народження Тиводара Легоцького. Ужгород, 5-6 жовтня 2005 року. Užgorod/Ужгород, 247-272.

BADER, T. 2009: Bemerkungen über ein wenig bekanntes Artefakt: Der Bronzezeitlichen Lanzenschuh im Karpaten-Donau-Raum - Opaskoe o jednom slabo poznatom artefaktu Brončanoga doba: Peta koplja u Karpatso-Podunavskom Prostoru. Vjesnik Arheološkog Muzeja 3/62, 129-156.

BALAhURI, E. A. 1966-1967: A medvegyevcei (medvefalvai bronzlelet) - Результатаы раскопок поселения конца эпохи брнзы и раннего железа возле с. Медведевцы (1964 - 1966 гг.). Móra Ferenc Múzeum Évkönyve 2, 79-83.

BALĂN, G. 2009: Cronologia şi Tipologia Dălţilor de Bronz cu Toc de Înmănuşare din România Chronology and Typology of the Bronze Socketed Chisels from Romania. Apulum - Acta Musei Apulensis 46, 1-40.

Ballmer, A. 2010a: Zur Topologie des bronzezeitlichen Deponierens. Von der Handlungstheorie zur Raumanalyse. Prähistorische Zeitschrift 85, 120-131.

Ballmer, A. 2010b: Measuring the Mental - A Quantitative Approach to Mental Landscape Concepts in Prehistory. In: Kiel Graduate School "Human Development in Landscapes" (eds.): Landscapes and Human Development: The Contribution of European Archaeology. Proceedings of the International Workshop "Socio-Environmental Dynamycs over the Last 12, 000 Years: The Creation of Landscapes $1^{\text {st }}-4^{\text {th }}$ April 2009. Bonn, 193-202.

BÁNDI, G. 1962: Ebergőci koravaskori kincslelet - Früheisenzeitlicher Schaztfund von Ebergőc. Archaeologiai Értesitón 89, 77-83.

BeHrens, G. 1917: Ein spätbronzezeitlicher Skelettgrab von Heldenbergen. Germania 1, 147-150.

BERANOvÁ, M. 1993: Versuche zur Vorgeschichtlichen und Frühmittelalterlichen Landwirtschaft Pokusy k Pravěkému a Časně Středověkému Zemědělství. Památky Archeologické 84/1, 97-119.

Bergerbrandt, S. 2007: Bronze Age Identities: Costume, Conflict and Contact in Northern Europe 16001300 BC. Stockholm Studies in Archaeology 43. Lindome.

Bernjakovič, K. 1960: Bronzezeitliche Hortfunde von rechten Ufergebiet des Oberen Theisstales. Slovenská Archeológia 8, 325-392. 
Bezzenberger, A. 1910: Zur Geschichte der Sichel. Mannus 2, 179-180.

BočKarev, V. S. - Leskov, A. M. 1980: Jung- und spätbronzezeitliche Gußformen im nördlichen Schwarzmeergebeit. Prähistorische Bronzefunde 19/1. München.

Boroffka, N. - Ridiche, F. 2005: Der Gußformenfund von Pleniţa, Kreis Dolj, Rumänien. - Descoperirea de tipare pentru turnarea bronzului de la Pleniţa, judeţul Dolj. In: Soroceanu, T. (Hrsg.): Bronzefunde aus Rumänien II. Beiträge zur Veröffentlichung und Deutung bronze- und älterhallstattzeitlicher Metallfunde in europäischem Zusammenhang - Descoperiri de Bronzuri din România II. Contribuţi la publicarea şi interpretarea descoperirilor de metal din epoca bronzului şi din prima vârstă a fierului în context european. Cluj-Napoca, 133-208.

BónA, I. 1959: Bronzkori övkapcsok és diadémák - Bronze Age Grindle-Clasps and Diadems. Archaeologiai Értesítő 86, 49-59.

Blajer, W. 1984: Die Arm- und Beinbergen in Polen. Prähistorische Bronzefunde 10/2. München.

BorN, H. 1992: $\mathrm{Zu}$ den Herstellungtechniken der Armringe aus dem Bronzefund von Lengyeltóti/Ugarn. Acta Praehistorica et Archaeologica 24, 289-294.

BudinskÝ-KričKA, V. 1970: Bronzový Depot z Bodrogu, Okres Trebišov - Der Bronzehort aus Bodrog, Bezirk Trebišov. Študijné Zvesti Archeologického Ústavu Slovenskej Akadémie Vied 18, 25-62.

BÜttner, A. - Linke, R. - Wirth, S. 2006: Reiche Gräber der Bronze-und Urnenfelderzeit und ein Depotfund mit Wagenbronzen von Oberottmarshausen. Das archäologische fahr in Bayern 2006, 53-56.

Bradley, R. 1990: The Passage of Arms. An Archaeological Analysis of Prehistoric Hoards and Votive Deposits. Cambridge.

Bruno, A. 2012: Spears in Context: Typology, Life-Cycles and Social Meanings in Bronze Age Italy. Doctoral Thesis - University of Manchester. Manchester.

von BrunN, W. A. 1968: Mitteldeutsche Hortfunde der jüngeren Bronzezeit. Römisch-Germanische Forschungen 29. Berlin.

Catling, W. H. 1977: "Panzer". In: Archaeologica Homerica 1. Kapitel E. Kriegswesen 1. Schutzwaffen und Wehrbauten. Göttingen, 74-118.

Chadwick, J. 1961: The Decipherment of Linear B. Harmondsworth.

Childe, V. G. 1929: The Danube in Prehistory. Oxford.

Ciugudean, H. - Luca, S. A. - Georgescu, A. 2006: Depozitul de Bronzuri de la Dipşa - The Bronze Hoard from Dipşa. Bibliotheca Brukenthal 5. Sibiu.

ČERČE, P. - Šinkovec, I. 1995: Katalog depojec pozne bronaste dobe - Catalogue of Hoards of the Urnfield Culture. In: TeržAn, B. (ed.): Depojske in posamezne kovinske najdbe bakrene in bronaste dobe na Slovenskem I. - Hoards and Individual Metal Finds from the Eneolithic and Bronze Age in Slovenia I. Ljubljana, 129-232.

ČIvilyté, A. 2009: Wahl der Waffen. Studien zur Deutung der bronzezeitlichen Waffendeponierung im nördlichen Mitteleuropa 1. Universitätsforschungen zur Prähistorischen Archäologie 167. Bonn 2009.

Clausing, Ch. 1996: Urnenfelderzeitliche Vorläufer Eisenzeitlicher Rippenzisten? Archäologisches Korrespondenzblatt 26, 413-431.

Clausing, Ch. 2003: Ein urnenfelderzeitliches Hortfund von Slavonski Brod, Kroatien. Jahrbuch des Römisch-Germanischen Zentralmuseums Mainz 50/1, 47-205. 
Clausing, Ch. 2005: Untersuchungen zu den urnenfelderzeitlichen Gräbern mit Waffenbeigaben vom Alpenkamm bis zur Südzone des Nordischen Kreises. Eine Analyse ihrer Grabinventare und Grabformen. British Archaeological Reports, International Series 1375. Alden.

Coblenz, W. 1989: Alte und neue Bronzemeißel und- punzen der Lausitzer Kultur aus Sachsen. Ausgrabungen und Funde 34/1, 13-32.

Czajlik, Z. - Molnár, F. - Sólymos, K. G. 1999: On the Origin of Late Bronze Age Semi-Products found at Celldömölk-Sághegy according to Electron-Mikroprobe (EPMA) Studies. Communicationes Archaeologicae Hungariae, 35-46.

CzAJLıK, Z. 1996: Ein spätbronzezeitliches Halbfertigprodukt: Der Gußkuchen. Eine Untersuchungen anhnad von Funden aus Westungarn. Archaeologia Austriaca 80, 165-180.

CzAjLik, Z. 2012: A Kárpát-medence fémnyersanyag-forgalma a későbronzkorban és a vaskorban. Budapest.

Dalton, G. 1965: Primitive Money. American Anthropologist 67, 44-65.

DemeterovÁ-PollákovÁ, S. 1973: Hrodmaný nález bronzových predmetov v Kopčanoch - Der Massenfund von Bronzegegenständen in Kopčan. Historica Carpatica 4, 109-129.

DergačEv, V. 2002: Die äneolithischen und bronzezeitlichen Metallfunde aus Moldavien. Prähistorische Bronzefunde 20/9. Stuttgart.

DiEtrich, O. 2009: Ein kleiner Bronzedepotfund aus der Siedlung von Rotbav, "La Pârâuţ" sowie einige Gedanken zum Auftreten zyprischer Schleifennadeln in der Noua-Kultur - A small Deposit of Bronzes from Rotbav, "La Pârâuţ" and some Thoughts on the Appearance of Cypriote Pins in the Noua Culture. Analele Banatului 17, 97-106.

DiEtrich, O. 2011: Zentralisierte Produktionsstrukturen, Überlegungen zur räumlichen Beziehung von Bronzezeitlichen Gussformen und Fertigprodukten in Südosteuropa am Beispiel der Rumänischen Tüllenbeile. Marisia. Studii şi Materiale - Arheologie 31, 77-91.

Distelberger, A. 1986: Der Jüngerurnenfelderzeitliche Depotfund vom "Gelände" bei Grünbach am Schneeberg, NÖ. Mitteilungen der Österreichischen Arbeits-Gemeinschaft für Ur- und Frühgeschichte 36, 71-96.

DudÁs, Gy. 1885: A zentai bronzleletekről. Archaeologiai Értesitő 6, 394.

DumitraşCu, S. - CrişAn, I. 1989: Depozitul de Bronzuri de la Şuncuiuş Judeţul Bihor. Crişia 19, 17-118.

Drews, R. 1993: The End of the Bronze Age. Changes in Warfare and the Catastrophe ca. 1200 B. C. New Jersey.

EcKers, R. 1996: Die Urnenfelderkultur in Ostbayern. Büchenbach.

EGG. M. - KRÄMER, D. 2005: Krieger - Feste - Totenopfer. Der letzte Hallstattfürst von Kleinklein in der Steiermark. Mainz.

EINwANGER, J. 1989: Talanton. Ein bronzezeitlicher Goldstandard zwischen Ägais und Mitteleuropa. Germania 67, 443-462.

Eogan, G. 2000: The Socketed Bronze Axes in Ireland. Prähistorische Bronzefunde 9/22. Stuttgart.

EŐRY, B. 1998-1999: A tokosbalta mint sokrétű munkaeszköz - Das Tüllenbeil als Vielseitiges Arbeitsgerät. Savaria 24/3, 437-446.

EőRY, B. 2009. Késő bronzkori fibula rekonstrukciója - Rekonstruktion einer spätbronzezeitlichen Fibel (Posamenteriefibel). Ösrégészetei Levelek - Prehistoric Newsletter 11, 135-138. 
Enăchiuc, V. 1995: Der Bronzfund von Dridu, Kr. Ialomiţa. In: SoRoceanu, T. (Hrsg.): Bronzefunde aus Rumänien. Prähistorische Archäologie in Südosteuropa 10. Berlin, 279-310.

ÉRDY, J. 1861: Kelenföldi pogány sírok. Archaeológiai Közlemények 2, 27-46.

Falkenstein, F. 2006-2007: Gewalt und Krieg in der Bronzezeit Mitteleuropas. Bericht der Bayerischen Bodendenkmalpflege 47/48, 33-52.

Fexete, M. 1995: Etliches über die Hallstattzeitlichen Hortfunde Transdanubiens. Specimina Nova Universitatis Quinqueecclesiensis 11, 37-48.

Ferenczy, B. 1976: A szobrászati technikák. In: Szőnyi, I. - Molnár, P. C. - Szobotka, I. - Elekfy, J. - VARgA, N. L. - Ferenczy, B. (szerk.): A képzőmúvészet iskolája I. Budapest 1976.

Filip, J. 1936-1937: Popelnicová pole a počátky zelezné doby v Čechach. Praha.

FilıP, J. 1939: Lužická kultura v Československu. Památky Archeologické 41, 14-51

FILIP, J. 1969: Enzyklopädisches Handbuch zur Ur-und Frühgeschichte Europas 2. (l-z). Praga.

Fleissig, J. 1941: A magyarkeresztesi lelet - Der Fund von Magyarkeresztes. Dunántúli Szemle 8/1-2, 288-296.

Fontijn, D. R. 2002: Sacrificial Landscapes. Cultural Biographies of Persons, Objects and 'Natural' places in the Bronze Age of Southern Netherlands, c. 2300 - 600 BC. Leiden.

Fontujn, D. R. 2008: Everything in it's right place? On selective deposition landscape and the construction of identity in later prehistory. In: Jones, A. (ed.): Prehistoric Europe. Theory and Practice. Blackwell Studies in Global Archaeology, 86-106.

Foltiny, S. 1955: Zur Chronologie der Bronzezeit des Karpatenbeckens. Antiquitas 2. Bonn.

FurmáneK, V. 1980: Die Anhänger in der Slowakei. Prähistorische Bronzefunde 11/5. München.

Furmánek, V. - NovotnÁ, M. 2006: Die Sicheln in der Slowakei. Prähistorische Bronzefunde 18/6. Stuttgart.

Furmánek, V. - Veliačik, L. - Vladár, J. 1999: Die Bronzezeit im Slowakischen Raum. Prähistorische Archäologie in Südosteuropa 15. Rahden/Westfalen.

GAÁL, A. 2001: Posameneteriefibel mit Fusspirale, Bronzebecken und Bronzehelm aus dem Donauabschnitt im Komitat Tolna. Communicationes Archaeologicae Hungariae, 41-50.

Гарашанин, Д. 1954: Каталог Метала. Праисорија I - Katalog der Vorgeschichtliche Metalle. Vorgeschichte I. Београд/Belgrad.

Gavranović, M. 2011: Die Spätbronzezeit-und Früheisenzeit in Bosnien 1. Universitätsforschungen zur Prähistorischen Archäologie 195. Bonn.

Gedu, M. 1995: Die Sicheln in Polen. Prähistorische Bronzefunde 18/4. Stuttgart.

Gedl, M. 2004a: Die Beile in Polen IV. (Metalläxte, Eisenbeile, Hämmer, Ambosse, Meißel, Pfrieme). Prähistorische Bronzefunde 9/24. Stuttgart.

GedL, M. 2004b: Die Fibeln in Polen. Prähistorische Bronzefunde 14/10. Stuttgart.

GedL, M. 2009: Die Lanzenspitzen in Polen. Prähistorische Bronzefunde 5/3. Mainz.

Glob, P. V. 1977: The Mound People: Danish Bronze Age Man Preserved. London.

GogÂltan, F. 2005: Zur Bronzeverarbeitung im Karpatenbecken. Die Tüllenhämmer und Tüllenambosse aus Rumänien. In: SoroceAnu, T. (Hrsg.): Bronzefunde aus Rumänien. Beiträge zur Veröffentlichung und Deutung bronze-und älterhallstattzeitlicher Metallfunde in europäischem Zusammenhang. Berlin, 343-386. 
Gogâltan, F. - Sava, V. 2010: Sântana cetatea Veche. O Fortificaţie de Pământ a Epocii Bronzului la Mureş de fos. A Bronze Age Earthwork on the Lower Mureș. Arad.

Gumă, M. - Dragomir, I. 1985: Un deposit de bronzuri din prima epocă a fierului descoperit la Liborajdea (com. Sicheviţa, jud. Caraş-Severin). Banatica 8, 107-122.

Hagl, M. 2008: Ein urnenfelderzeitlicher Depotfund vom Bullenheimer Berg in Franken (Horf F). Bayerische Vorgeschichtsblätter 19. München.

HÁjek, L. 1959: Kostěnáindustrie otomanské kultury z Barce. Slovenská Archeológia 7/2, 285-300.

Hampel, J. 1877: Antiquités Préhistoriques de la Hongrie. Esztergom.

HAMPEL, J. 1880: A Marmarosmegyei aranylelet. Archaeologiai Értesító 14, 29-32.

HAMPEL, J. 1886a: A bronzkor emlékei Magyarhonban I: Képes Atlasz. Budapest.

HAMPEL, J. 1886b: Sajó és Rimavidéki Bronzleletek. Archaeologiai Értesítő 6, 11-27.

HAMPEL, J. 1892: A bronzkor emlékei Magyarhonban II: A leletek statisztikája. Budapest.

HAMPEL, J. 1895: Három dunántúli bronzlelet. Archaeologiai Értesítő 15, 97-115.

HAMPEL, J. 1896: A bronzkor emlékei Magyarhonban III: Áttekintő ismertetés. Budapest.

HANSEN, S. 1994: Studien zu den Metalldeponierungen während der älteren Urnenfelderzeit zwischen RHÔNETAL und Karpatenbecken 1. Universitätsforschungen zur Prähistorischen Archäologie 5. Bonn.

Hansen, S. 1996: Bemerkungen zur Zeitlichen Stellung der Hortunde des Typus Gyermely. Archäologisches Korrespondenzblatt 26, 433-441.

HANsen, S. 2006: Elemente einer Geschichte der Hortung. In: J. V. KobaL' (Hrsg.): Bronzezeitlichen Depotfunde - Probleme der Interpretation. Materialien der Festkonferenz für Tovodor Lehoczky zum 175. Geburtstag. Ushhorod, 5-6. Oktobor 2005. - Скарби доби бронзи - проблема інтерпретації Матеріали Конференції присвяченоії 175-річчю від дня народження Тиводара Легоцького. Ужгород, 5-6 жовтня 2005 року. Užgorod/ Ужгород, 55-75.

Hansen, S. 2008: Bronzezeitliche Horte als Indikatoren für andere Orte. Das Altertum 53, 291-314.

HänSEL, A. 1999: Ein alterurnenfelderzeitliches Depot aus Pustakovec, Kot. Čakovec, Kroatien. Acta Praehistorica et Archaeologica 31, 76-92.

HäNSEL, B. 1968: Beiträge zur Chronologie der mittleren Bronzezeit im Karpatenbecken. Beiträge zur ur- und frühgeschichtlichen Archäologie des Mittelmeer-Kulturraumes 8. Bonn.

Hänsel, B. 1997: Das metallene Tafelgeschirr im Opfer. In: HäNSEL, A. - HäNSEL, B. (Hrsg.): Gaben an die Götter. Schätze der Bronzezeit Europas. Austellung der Freien Universität Berlin in Verbindung mit dem Museum für Vor-und Frühgeschichte, Staatliche Museen zu Berlin Preußlicher Kulturbesitz. Berlin, 83-86.

Harding, A. F. 2007: Warriors and Weapons in Bronze Age Europe. Archaeolingua Series Minor 25. Budapest.

Harding, A. F. 2000: European Societies in the Bronze Age. Cambridge World Archaeology. Cambridge.

B. Hellebrandt, M. 1986: A II. sárospataki bronzlelet - Der II. Bronzefund von Sárospatak. Communicationes Archaeologicae Hungariae, 5-15.

B. Hellebrandt, M. 1989: A pácini IV. bronzlelet - Der Bronzefund von Pácin. Communicationes Archaeologicae Hungariae, 97-113. 
Hermann, R.-F. 1966: Die Funde der Urnenfelderkultur in Mittel-und Südhessen. Römisch-Germanische Forschungen 27. Berlin.

HETESI, Sz. 2004: Késő bronzkori lándzsacsúcs Csenéről (Cenei, Románia). Ösrégészeti Levelek - Prehistoric Newsletter 6, 58-61.

Holste, F. 1951: Hortfunde Südosteuropas. Marburg/Lahn.

Horváth, I. - Kelemen, H. - Torma, I. 1979: Komárom megye régészeti topográfiája. Esztergom és dorogi járás. Magyarország Régészeti Topográfiája 5. Budapest.

HöGlinger, P. 1991: Ein Depotfund aus Oberösterreich. Archäologie Österreichs 41, 35-38.

HöскмANN, O. 1980: Lanze und Speer im spätminoischen und mykenischen Griechenland. fahrbuch des Römisch-Germanischen Zentralmuseums 27, 13-159.

Hralová, J. - Hrala, J. 1971: Hromadný nález bronzů z Březovic u Chrudimi (S úvahou o mlado- a pozdně bronzových kladivech - Bronzehortfund von Březovice bei Chrudim (Mit der Erwägung über jung- und spätbronzezeitlicher Hämmer. Archeologické rozhledy 22/1, 3-26.

IloN, G. 1992: Keftiubarren ingot from an Urn-Grave Culture settlement at Gór-Kápolnadomb (c.Vas). Acta Archaeologica Acadaemiae Scientiarum Hungaricae 44, 239-254.

ILON, G. 2002: Ein spätbronzezeitlicher Hortfund aus Szombathely (Steinamanger). Kom. Vas (Ungarn). Das Altertum 47, 149-169.

ILON, G. 2011: Szombathely-Zanat késő urnamezős korú temetője és a lelőhely más ős-és középkori emlékei - The Late Urnfield period cemetery from Szombathely-Zanat supplemented by an assessment of prehistoric and Medieval settlement features. Budapest.

Јацановић, Д. 1986: Праисторијска остава бронзаних мредмета из села клења код Толупца. Старинар 37, 153-173.

JACANović, D. 1994-1995: Metallgefäße aus der späten Bronzezeit und frühen Eisenzeit in Serbien. Starinar 45-46, 101-112.

JACOB-Friesen, G. 1967: Bronzezeitlichen Lanzenspitzen Norddeutschland und Skandinaviens. Veröffentlichenungen der urgeschichtlichen Sammlungen des Landesmuseums zu Hannover 17. Hildesheim.

Jankovits, K. 1999-2000: Neue Angaben zu dem Depotfund von Pila del Brancon, Nogara (Verona). Zu den Bronzebelchen vom Depotfund. Acta Archaeologica Academiae Scientiarum Hungaricae $51,189-205$.

Jantzen, D. 2008: Quellen zur Metallverarbeitung im Nordischen Kreis der Bronzezeit. Prähistorische Bronzefunde 19/2. Stuttgart.

Jovanović, D. 2010: Ostave Vršačkog Gorja. Markovac-Grunjac. Vršac.

JósA, A. - Kemenczei, T. 1963-1964: Bronzkori Halmazleletek - Depotfunde aus der Bronzezeit. A Nyíregyházi fósa András Múzeum Évkönyve 6-7, 19-45.

Jungbert, B. 1986: Spätbronzezeitlicher Depotfund von Tatabánya-Ótelep. Communicationes Archaeologicae Hungariae, 17-25.

Kacsó, C. 1995: Der Hortfund von Arpăşel, Kr. Bihor. In: Soroceanu, T. (Hrsg.): Bronzefunde aus Rumänien. Prähistorische Archäologie in Südosteuropa 1. Berlin, 15-80.

KAcsó, C. 1996: Der Bronzefund von Crasna Vişeului. In: KovÁcs, T. (Hrsg.): Studien zur Metallindustrie im Karpatenbecken und den benachbarten Regionen. Festschrift für Amália Mozsolics zum 85. Geburtstag. Budapest, 249-263. 
Kacsó, C. 2006: Bronzefunde mit Goldgegenständen im Karpatenbecken. In: KoBAL', J. V. (Hrsg.): Bronzezeitlichen Depotfunde - Probleme der Interpretation. Materialien der Festkonferenz für Tovodor Lehoczky zum 175. Geburtstag. Ushhorod, 5.-6. Oktobor 2005. - Скарби доби бронзи проблема інтерпретації - Матеріали Конференції присвяченоії 175-річчю від дня народження Тиводара Легоцького. Ужгород, 5-6 жовтня 2005 року. Užgorod/Ужгород, 76-124.

KAlicz-Schreiber, R. 2010: Ein Gräberfeld der Spätbronzezeit von Budapest-Békásmegyer. Bearbeitet und fertigestellt von N. Kalicz und G. Váczi. Mit Beiträgen von B. Hänsel, B. Heußer. Budapest.

Kalla, G. 2000: Megjegyzések a Kárpát-medence „Keftiu-tömbök” és az őskori „pénz” kérdéséhez. Ósrégészeti Levelek - Prehistoric Newsletter 2, 83-89.

KARAVANIĆ, S. 2007: Slučajni nalaz brončanog pojasa iz naselja Mačkovac-Crišnjevi (Nova Gradiška) - Zufallsfund eines Bronzegürtels aus der Siedlung Mačkovac-Crišnjevi (Nova Gradiška). Izvorni znanstevi rad Prapovijesna arheologija 27, 59-67.

Karavanić, S. 2009: The Urnfield Culture in Continental Croatia. BAR International Series 2036. Oxford.

KARAVANIĆ, S. 2010: Sljepočničarke i struktura grobnih priloga na groblju u Velikoj Gorici. - Temple rings and the structure of grave goods found in the Velika Gorica graveyard. Prilozi Instituta za Arheologiju u Zagrebu 27, 83-94.

Karavanić, S. - Mihaljević, M. 2001: Ostava iz Mačkovca - Mačkovac Hoard. Vjesnik Arheoloskog muzeja u Zagrebu 34/3, 7-36.

KAšuba, M. 2008: Die ältesten Fibeln im Nordpontus. Versuch einer Typologie der einfachen Violinbogenfibeln in südlich Mittel-, Süd-und Südosteuropa. Eurasia Antiqua 14, 193-231

Kemenczei, T. 1966: Koravaskori bronz raktárleletek a Miskolci Múzeumban - Früheisenzeitliche Bronze-Depotfunde im Museum von Miskolc. A Herman Ottó Múzeum Évkönyve 6, 49-107.

Kemenczei, T. 1969: Újabb bronzleletek Borsod megyéből - Neue Bronzefunde im Komitat Borsod. Hermann Ottó Múzeum Évkönyve 8, 27-68.

KemenczeI, T. 1972: A Gyöngyössolymos-Kishegyi bronzleletek - Die Bronzefunde in Gyöngyössolymos-Kishegy. Agria. Egri Múzeum Évkönyve 8-9, 133-144.

Kemenczei, T. 1980: A Gyöngyössolymos-Kishegyi negyedik bronzlelet. - Der Vierte Bronzefund von Gyöngyössolymos - Kishegy. Agria. Az Egri Múzeum Ékönyve 16-17, 137-155.

KemenczeI, T. 1983: A Tatabánya-bánhidai bronzlelet - Der Bronzefund von Tatabánya-Bánhida. Archaeologiai Értesító 110, 61-68.

Kemenczei, T. 1984: Die Spätbronzezeit Nordostungarns. Archaeologia Hungarica 51. Budapest.

KemeczeI, T. 1996: Angaben ur Frage der endbronzezeitlichen Hortfundstufen im Donau-Theißgebiet. Communicationes Archaeologicae Hungariae, 53-92.

Kemenczei, T. 1999: Spätbronzezeitliche Goldschatzfunde. In: Kemenczei, T. - Raczky, P. (Hrsg.): Prähistorische Goldschätze aus dem Ungarischen Nationalmuseum. Budapest, 63-79.

Kemenczei, T. 2003: Der Erste Bronzefund von Bodrogkeresztúr. Archaeologiai Értesítő 128, 17-49.

KibBert, K. 1984: Die Äxte und Beile im mittleren Westdeutschland II. Prähistorische Bronzefunde 9/13. Frankfurt.

Kilian-Dirlmeier, I. 1975: Gürtelhaken, Gürtelbleche und Blechgürtel der Bronzezeit in Mitteleuropa. (Ostfrankreich, Schweiz, Süddeutschland, Österreich, Tsechoslowakei, Ungarn, Nordwest-fugoslawien). Prähistorische Bronzefunde 12/2. Frankfurt. 
Kiss, F. 1859: A karikapénz, mint fizetési és ékszer a történet előtti korban s annak szabályozott pénzrendszerre történt fokozatos átmenetele s végre megszűnése. Archaeologiai Közlemények $1,174-216$.

Koвal', J. V. 2000: Bronzezeitliche Depotfunde aus Transkarpatien (Ukraine). Prähistorische Bronzefunde 20/4. Frankfurt.

KopytofF, I. 1986: The cultural biography of things: commodization as process. In: AppaduraI, A. (ed.): The Social Life of Things. Cambridge, 64-91.

Коsснік, H. 1981: Ein Hortfund der späten Urnenfelderzeit von Fridolfing, Ldkr. Traunstein, Oberbayern. Bayerische Vorgeschichtsblätter 46, 37-56.

KNöPкE, S. 2009: Der urnenfelderzeitliche Männerfriedhof von Neckarsulm. Stuttgart.

KöNIG, P. 2004: Spätbronzezeitliche Hortfunde aus Bosnien und der Herzegowina. Prähistorische Bronzefunde 20/11. Stuttgart.

KözÉPEssy, G. 1901: Régészeti kutatások Ér-Köbölkúton Bihar vármegyében. Archaeologiai Értesitő $21,363-368$.

KősZEGi, F. 1984: A történelem küszöbén. Budapest.

Köszegr, F. 1988. A Dunántúl története a későbronzkorban - The History of Transdanubia during the Late Bronze Age. BTM Mühely 1. Budapest.

Kuijpers, M. H. G. 2008: Bronze Age Metalworking in the Netherlands (c. $2000-800$ BC). A research into the preservation of metallurgy related artefacts and the social position of the smith. Leiden.

Kuśnierz, J. 1998: Die Beile in Polen III. Prähistorische Bronzefunde 9/21. Stuttgart.

KuzsinszKy, B. 1920: A Balaton környékének archaeologiája. Lelőhelyek és leletek. Budapest.

KytuICovÁ, O. 1959: Př́íspěvek k otázce bronzových tepaných nádob z mladší a pozoní dobry bronzové - Ein Beitrag zum Problem der getriebenen Bronzegefäße aus der jüngeren und späten Bronzezeit. Památky Archeologické 50, 120-157.

KytuIcovÁ, O. 1991: Die Bronzegefäße in Böhmen. Prähistorische Bronzefunde 2/12. Stuttgart.

KytlicovÁ, O. 2007: Jungbronzezeitliche Hortfund in Böhmen. Prähistorische Bronzefunde 20/12. Stuttgart.

LANGENECKeR, U. 1994: Ein mittelbronzezeitlicher Blechgürtel vom Typ Sieding-Szeged aus Margarethen am Moos, Niederösterreich. Fundberichte aus Österreichs 33, 269-272.

LaUX, F. 1971: Die Bronzezeit in der Lüneburger Heide. Veröffentlichungen Urgeschichtlichen Slg. Landesmuseums Hannover 18. Hildesheim.

LÁzÁr, A. 1943: A sághegyi őskori telep bronzművessége - Die Bronzeindustrie der urzeitlichen Siedlung am Sághegy. Dunántúli Szemle 10, 280-287.

Leнóczky, T. 1892: A dankófalvai bronzleletről. Archaeologiai Értesító 12, 349-352.

Leshtakov, L. 2011: Late Bronze and Early Iron Age Bronze Spear-and Javelinheads in Bulgaria in the Context of Southeastern Europe - Бронзови върхове на копия от къснобронзовия и ранножелезния период в България в контекста на югоизточна Европа. Archaeologia Bulgarica 15/2, 25-52.

Lochner, M. 1991: Studien zur Urnenfelderkultur im Waldviertel - Niederösterreich. Wien.

Lochner, M. 1998 - 1999: Ein Schmuckdepot der Urnenfelderzeit aus Thunau am Kamp, Niederösterreich. Archaeologia Austriaca 82-83, 181-186. 
MAKARovÁ, E. 2008. Ženký kroj lužickej kultúry v dobe bronzovej na Slovensku. Pokus o rekonštrukciu na základe hrobových nálezov a depotov. - Female Costume of the Slovak Branch of the Lusatian Culture in the Bronze Age. An Attampt at the Reconstruction on the Ground of Grave and Hoard Findings. Študijné Zvesti AÚSAV 44, 65-188.

MakkaY, J. 2006: The Late Bronze Age Hoard of Nadap - A nadapi (Fejér megye) késő bronzkori raktárlelet. Fósa András Múzeum Évkönyve 68, 135-184.

Malim, T. - Boreham, S. - Knight, D. - Nash, G. - Preece, R. - Scwenninger, J.-L. 2010: The Environmental and Social Contet of the Isleham Hoard. The Antiquaries fournal 90, 73-130.

MARÁz, B. 1989: Az őskori bronzművesség virágkora a Dél-Dunántúlon. Baranya Történeti és Honismereti Folyóirat 2, 7-25.

Mayer, E. F. 1977: Die Äxte und Beile in Österreich. Prähistorische Bronzefunde 9/9. München.

MÁrton, L. 1907: A féregyházi őskori aranylelet. Archaeologiai Értesitő 27, 57-68.

MÁrton, L. 1911: A Magyarhoni fibulák osztályozása. Archaeologiai Értesítő 31, 329-352.

McGovern, P. 2009: Uncorking the Past: The Quest for Wine, Beer, and Other Alcoholic Beverages. California.

Menghin, O. 1937: Die vorgeschichtliche Fund Voralbergs. Wien.

MÉszÁros, Gy. 1971-1972: A nagyvejkei későbronzkori kincslelet - Die Hortfunde aus Spätbronzezeit von Nagyvejke. Szekszárdi Béri Balogh Ádám Múzeum Évkönyve 2-3, 19-66.

MészÁros, Gy. 1977-1978: Késő bronzkori kincslelet Dombóvár-Szarvasd pusztán - Spätbronezeitlicher Depotfund aus Dombóvár-Szarvas puszta. Szekszárdi Béri Balogh Ádám Múzeum Évkönyve 8-9, 3-22.

Милошевин, П. 1960: Бронзана остава из Пећинаца. Рад Војвоваансих Музеја 9, 156-175.

Miske, K. 1907: A Velem Szt. Vidi őstelep - Die Prähistorische Ansiedlung Velem St. Vid. Wien.

Miske, K. 1910: A Hallstatt-kor hazai és egyébb európai nevezetesebb kapcsolótüi. Múzeumi és Könyvtári Értesítő 4, 66-77.

MODRIJAN, W. 1953: Der urnenfedlerzeitliche Grabfund aus Wörschach im Ennstal und die steirischen Schwerter der Periode Hallstatt A. Schild von Steier 2, 24-48.

Montageagudo, I. 1977: Die Beile auf der Iberischen Halbinsel. Prähistorische Bronzefunde 9/6. München.

Motzoi-Chicideanu, I. - Iuga, G. 1995: Der Bronzefund von Bogdan Vodă, Kr. Maramureş. In: Soroceanu, T. (Hrsg.): Bronzefunde aus Rumanien. Prähistorische Archäologie in Südosteuropa 10. Berlin, 141-168.

Mozsolics, A. 1942: A magyarkeresztesi (Vas megye) bronzlelet. Archaeologiai Értesítő 3, 155-161.

Mozsolics, A. 1943: A magyarországi bronzkor kronológiájáról. Erdélyi Tudományos Füzetek 169. Kolozsvár.

Mozsolics, A. 1949: Két dunántúli bronzlelet a hallstattkorból. Archaeologiai Értesítő 76, 26-29.

Mozsolics, A. 1950: Der Goldfund von Velem Szentvid. Ein Beitrag zur Metallkunst der älteren Hallstattziet. Praehistorica 1. Basel.

Mozsolıcs, A. 1963a: Der Bronzefund von Ópályi. Acta Archaeologica Academiae Scientiarum Hungaricae $15,65-82$. 
Mozsolics, A. 1963b: A két nagykállói depotlelet és a telekoldali bronzlelet vizsgálata. - Zwei Depotfunde von Nagykálló (Kom. Szabolcs-Szatmár) und die Spektrographische Untersuchungen einiger Bronzen von Telekoldal. Archaeologiai Értesító 90, 252-263.

Mozsolics, A. 1967: Bronzefunde des Karpatenbeckens. Depotfundhorizonte von Hajdúsámson und Kosziderpadlás. Budapest.

Mozsolics, A. 1973: Bronze-und Goldfunde des Karpatenbeckens. Depotfundhorizonte von Forró und Ópályi. Budapest.

Mozsolics, A. 1975: Somogy megyei bronzleletek - Bronzefund aus Kom Somogy. Somogy Megyei Múzeumok Közleményei 2, 5-21.

Mozsolics, A. 1984: Ein Beitrag zum Metallhandwerk der ungarischen Bronzezeit. Bericht der Römisch-Germanischen Komission 65, 19-72.

Mozsolics, A. 1985: Bronzefunde aus Ungarn. Depotfundhorizonte von Aranyos, Kurd und Gyermely. Budapest.

Mozsolics, A. 2000: Bronzefunde aus Ungarn. Depotfundhorizonte Hajdúböszörmény, Románd und Bükkszentlászló. Prähistorische Archäologie in Südosteuropa 17. Kiel.

MöDlinger, M. 2011: Herstellung und Verwendung bronzezeitlicher Schwerter Mitteleuropas. Eine vertiefende Studie zur mittelbronze-und urnenfelderzeitlichen Bewaffnung und Sozialstruktur. Universitätsforschungen zur Prähistorischen Archäologie 193. Bonn.

MüLLER, R. 2006a: Késő bronzkori magaslati település kutatása Várvölgy, Nagyláz-hegyen (20032006) - Investigation of a hill settlement from the Late Bronze Age at Várvölgy, Nagyláz-hegy (2003-2006). Régészeti Kutatások Magyarországon, 5-26.

MüLLER, R. 2006b: Várvölgy-Nagy-Lázhegy késő bronzkori földvár kutatása - Erforschung des spätbronzezeitlichen Burgwalles von Várvölgy-Nagy-Lázhegy. In: KovÁcs, Gy. - MıkLós, Zs. (eds.): “Gondolják, látják az várnak nagy voltát..." Tanulmányok a 80 éves Nováki Gyula tiszteletére. Burgenkundliche Studien zum 80. Geburtsag von Gyula Nováki. Budapest, 227-236.

MÜLLER, R. 2011: Keménységvizsgálatok a Várvölgy-Nagy-Lázhegy-i késő bronzkori eszközökön. In: Kővári, K. - Miklós, Zs. (szerk.): Fél Évszázad terepen. Tanulmánykötet Torma István tiszteletére 70. születésnapja alkalmából. Budapest, 211-224.

Müller-KaRpe, H. 1959a: Beiträge zur Chronologie der Urnenfelderzeit nördlich und südlich der Alpen. Text. Römisch-Germanische Forschungen 22. Berlin.

Müller-Karpe, H. 1959b: Beiträge zur Chronologie der Urnenfederzeit nördlich und südlich der Alpen. Tafeln. Römisch-Germanische Forschungen 22. Berlin.

Nagler-Zainer, C. 2010: Neues zum bronzezeitlichen Depotfund von Weidachwies, Gemeinde Aschau i. Chiemgau. Bericht der Bayerischen Bodendenkmalpflege 51, 31-47.

НАђ, Ш. 1955: Бронзана остава из новог ъечеја. Рад војвотанских музеја 4 (1955) 43-61.

NAGY, M. 2007: Bronzkori kartekercs Hegyhátszentmárton határából. - Bronzezeitliche Armspirale in der Gemarkung von Hegyhátszentmárton. Savaria a Vas Megyei Múzeumok Értesítője 31, 279-299.

NAUE, J. 1887: Die Hügelgräber zwischen Ammer-und Staffelsee. Stuttgart.

Nebelsick, L. 1997: Auf Biegen und Brechen. Ekstatische Elemente bronzezeitlicher Materialopfer ein Deutungsversuch. In: Hänsel, A. - Hänsel, B. (Hrsg.): Gaben and die Götter. Schätze der Bronzezeit Europas. Bestandkataloge des Seminars für Ur-und Frühgeschichte der Freien Universität zu Berlin 4. Berlin, 35-41. 
Neumann, D. 2010: Depositions of the Bronze Age - Perception and Cultural Practice. Prehistoric Landscapes. In: Kiel Graduate School „Human Development in Landscapes” (ed.), Landscapes and Human Development: The Contribution of European Archaeology. Proceedings of the International Workshop „Socio-Environmental dynamics over the Last 12,000 Years: The Creation of Landscapes (1st-4th April 2009)". Bonn, 237-248.

Neuninger, H. 1976: Spektralanalytische Untersuchung eines Tüllenmeißels aus Feistritz, Kärnten. Archaeologia Austriaca 59/60, 441-443.

NesseL, B. 2012: Alltägliches Abfallprodukt oder Marker bevorzugter Gusstechnik? Zu bronzenen Gusszapfen zwischen Karpaten und Ostsee. In: Heske, I. - HoRejs, B. (Hrsg.): Bronzezeitliche Identitäten und Objekte. Beiträge aus den Sitzungen der AG Bronzezeit auf der 80. Tagung des West-und Süddeutschen Verbandes für Altertumsforschung in Nürnberg 2010 und dem 7. Deutschen Archäologiekongress in Bremen 2011. Universitätsforschungen zur prähistorischen Archäologie 221. Bonn, 145-159.

NestoR, J. 1932: Der Stand der Vorgeschichtsforschung in Rumänien. Bericht der Römisch-Germanischen Komission 22, 11-181.

Nienhuis, J. - Sietsma, J. - Arnoldussen, S. 2011: The Production Process and Potential Usage of Bronze Geistingen axes. Journal of Archaeology in the Low Countries 3-1/2, 47-63.

NovÁk, M. - VÁczi, G. 2012: Késő bronzkori fegyverlelet a Bakonyból - Megjegyzések az urnamezős művelődés fegyverdeponálási szokásaihoz - A Late Bronze Age weapon find from the Bakony region, Hungary - Notes on the weapon deposition practices of the Urnfield culture. Ósrégészeti Levelek - Prehistoric Newsletter 12, 94-114.

Novotná, M. 1970a: Die Bronzefunde in der Slowakei. Bratislava 1970.

NovotnÁ, M. 1970b: Die Äxte und Beile in der Slowakei. Prähistorische Bronzefunde 9/3. München.

NovotnÁ, M. 1980: Die Nadeln in der Slowakei. Prähistorische Bronzefunde 13/6. München.

NovotnÁ, M. 1981: Zur Stellung und Funktion Einiger Typen der Bronzeindustrie in der älteren Bronzezeit. - К месту и функции некоторых типов бронзовой индустурии раннего периода бронзы. Slovenská Archeológia 29/1, 121-129.

NovotnÁ, M. 1984: Halsringe und Diademe in der Slowakei. Prähistorische Bronzefunde 11/4, München.

NovotnÁ, M. 2000: K Depotom Horizontu Gyermely v Karpatskej Kotline - Zu den Bronzehortfunden des Horizontes Gyermely. Pravěk Nová Řada 10, 365-377.

NovotnÁ, M. 2001: Die Fibeln in der Slowakei. Prähistorische Bronzefunde 14/10. Stuttgart.

Oszvald, F. - Szabó, G. 1996: Késő bronzkori karikaleletek Kisdorog és Szakályból. Wosinszky Mór Múzeum Évkönyve 19, 89-113.

Ottaway, B. S. - Roberts, B. 2003: The Use and Significance of Socketed Axes during the Late Bronze Age. European Fournal of Archaeology 6/2, 119-140.

PABST, S. 2011: Die grossräumige Ausbreitung der Brillenfibeln am Übergang von Bronze-zur Eisenzeit - Kommunikationswege und soziale Hintergründe. In: Dietz, U. L. - Jockenhövel, A. (Hrsg.): Bronzen im Spannungsfeld zwischen praktischer Nutzung und symbolsicher Bedeutung. Beiträge zum internationalen Kolloquium am 9. und 10. Oktober 2008 in Münster. Prähistorische Bronzefunde 20/13. Stuttgart.

PANČíkovÁ, Z. 2008: Metalurgia v období popolnicových polí na Slovensku. - Urnenfelderzeitliche Metallurgie in der Slowakei. Památky Archeologické 99, 93-160. 
PARE, Ch. F. E. 1987: Wheels with thickened spokes, and the Problem of Cultural Contact between the Aegean World and Europe in the Late Bronze Age. Oxford fournal of Archaeology 6/1, 43-61.

Pare, Ch. F. E. 2004: Die Wagen der Bronzezeit in Mitteleuropa. In: FAnsa, M. - Burmeister, S. (eds.): Rad und Wagen. Der Ursprung einer Innovation Wagen im Vorderen Orient und Europa. Mainz, $355-372$.

Patay, P. 1964: A bokodi bronzlelet - Der Bronzefund von Bokod. Folia Archaeologia 16, 7-21.

PatAY, P. 1969: Der Bronzefund von Mezőkövesd. Acta Archaeologica Academiae Scientiarum Hungaricae $21,167-216$.

Patay, P. 1990: Die Bronzegefäße in Ungarn. Prähistorische Bronzefunde 2/10. München.

PAtek, E. 1968: Die Urnenfelderkultur in Transdanubien. Archaeologica Hungarica 44, Budapest.

Paul, I. 1994: Sîntana. In: MeIer-Arendt, W. (Hrsg.): Goldhelm, Schwert und Silberschätze: Reichtümer aus 6000 fahren rumänischen Vergangheit. Austellungskatalog Frankfurt am Main 1994. Frankfurt, 137.

PAulík, J. 1959: Ružicové spony zo Slovenska - Posamenteriefibeln in der Slowakei. Slovenská Archaeológia 7, 328-362.

PAulík, J. 1962: Das Velatice-Baierdorfer Hügelgrab in Očkov. Slovenská Archeológia 10/1, 5-96.

PAulík, J. 1965: Verzeichnis der Kupfer-und Bronzegegenstände im Heimatkundlichen Museum zu Rimavská Sobota. Studijné Zvesti AUSAV, 33-106.

PÁszthory, K. 1985: Der Bronzezeitlichen Arm-und Beinschmuck in der Schweiz. Prähistorische Bronzefunde 10/3. München.

PÁszthory, K. - Mayer, E. F. 1998: Die Äxte und Beile in Bayern. Prähistorische Bronzefunde 9/20. Stuttgart.

Perkić, D. - LožNJak Dizdar, D. 2005: Kasnobrončanodobna ostava Siča/Lučica - The Siča/Lučica Late Bronze Age Hoard. Opuscula Archaeologica 29, 41-119.

F. Petres, É. 1960: A Székesfehérvári kora vaskori kincslelet - Der früheisenzeitliche Schatzfund von Székesfehérvár. Folia Archaeologica 12, 35-43.

F. Petres, É. 1982: Neue Angaben über die Verbreitung der spätbronzezeitlichen Schutzwaffen. Savaria $18,57-80$.

Petrescu-Dîmboviţa, M. 1977: Depozitele de Bronzuri din România. București.

Petrescu-Dîmboviţa, M. 1978: Die Sicheln in Rumänien mit Corpus der jung-und spätbronzezeitliche Horte in Rumäniens. Prähistorische Bronzefunde 18/1. München.

Petrescu-Dîmboviţa, M. 1998: Der Arm- und Beinschmuck in Rumänien. Prähistorische Bronzefunde 10/4. Stuttgart.

PitTioni, R. 1941: Beiträge zur Urgeschichte der Landschaft Burgenand im Reichsgau Niederdonau. Wien.

Pittioni, R. 1967: Ein urnenfelderzeitliche Depotfund aus Donnerskirchen, p. B. Eisenstadt, Burgenland. Archaeologia Austriaca 41, 66-73.

Primas, M. 1986: Die Sicheln in Mitteleuropa I. (Österreich, Schweiz, Süddeutschland). Prähistorische Bronzefunde 18/2.

Prüssing, G. 1991: Die Bronzegefäße in Österreich. Prähistorische Bronzefunde 2/5. Stuttgart. 
Pulszky, F. 1883: A rézkor Magyarországon. Budapest.

Pulszky, F. 1897: Magyarország archaeológiája. Budapest.

Рашајски, Р. 1988: Остава бронзана предмета из Мајдана крај Вшца - Le trésor des objets de bronze de Majdan près de Vršac. Старинар 39, 15-28.

REINECKE, P. 1899: Tanulmányok a Magyarországi Bronzkor Chronologiájáról (Első közlemény) Studien zur Chronologie des ungarländischen Bronzealters. I. Teil. Prähistorisches aus Ungarn und den Nachbarländern. Ethnologishe Mitteilungen aus Ungarn. Archaeologiai Értesító 19, 225-251, 316-340.

REINECKE, P. 1900: Brandgräber vom Beginn der Hallstattzeit aus den östlichen Alpenländern und die Chronologie des Grabfeldes von Hallstatt. Mitteilungen der Anthropologischen Gesellschaft Wien 30, 44-52.

ReInecke, P. 1902: Zur Chronologie der 2. Hälfte des Bronzealters in Süd-und Norddeutschland. Korrespondenzblatt der deutschen Gesellschaft für Anthropologie, Ethnologie und Urgeschichte 33/3, 1732.

Rezi, B. 2009: Depozitul de Bronzuri de la Cetatea de Baltă (Jud. Alba) - The bronze Hoard from Cetatea de Baltă (Alba County). Analele Banatului 17, 47-65.

REzI, B. 2011: Voluntary Destruction and Fragmentation in Late Bronze Age Hoards from Central Europe. In: Berecki, S. - Németh, R. E. - Rezi, B. (eds.): Bronze Age Crafts and Craftsmen in the Carpathian Basin. Târgu Mureş, 303-314.

REzI, B. 2013: Reconstructing a Bronze Smith's Toolkit. Special Remarks Regarding the Decoration of the Bronze Belts from Band. In: Rezi, B. - Németh, R. E. - Berecki, S. (eds.): Bronze Age Crafts and Craftsmen in the Carpathian Basin.Târgu Mureş, 239-249.

Richter, I. 1970: Der Arm-und Beinschmuck der Bronze-und Urnenfelderzeit in Hessen und Rheinhessen. Prähistorische Bronzefunde 10/1. München.

ŘíHovskÝ, J. 1982: Základ středo dunajských popelnicovych ploi na Moravĕ. Studie Archeologického ústavu Československé Akademie věd v. Brné 10/1. Praha.

Ř́́tovsкÝ, J. 1989: Die Sicheln in Mähren. Prähistorische Bronzefunde 18/3. München.

Ř́́novsкý, J. 1992: Die Äxte, Beile, Meißel und Hämmer in Mähren. Prähistorische Bronzefunde 9/17. Stuttgart.

ŘínovsкÝ, J. 1993: Die Fibeln in Mähren. Prähistorische Bronzefunde 18/3. München.

Ř́́novsкÝ, J. 1996: Die Lanzen-, Speer-und Pfeilspitzen in Mähren. Prähistorische Bronzefunde 5/2. Stuttgart.

Rusu, M. 1963: Die Verbreitung der Bronzehorte in Transsilvanien vom Ende der Bronzezeit bis in die mittlere Hallstattzeit. Dacia 7, 177-210.

Rusu, M. 1981: Bemerkungen zu den großen Werkstätten-un Gießereifunden aus Siebenbürgen. In: LoRen, H. (Hrsg.): Studien zur Bronzezeit. Festschrift für Wilhelm Albert v. Brunn. Mainz/Rhein, 375-395.

Rychner, V. - Billamboz, A. - Bocguet, A. - Gassman, P. - Gebus, L. - Klac, Th. - Marcuet, A. SснӧвеL, C. 1995: Stand und Aufgaben Dendrochronologischer Forschung zur Urnenfelderzeit. In: Erbach, M. - Fokkens, H. - Gediga, B. (Hrsg.): Beiträge zur Urnenfelderzeit nördlich und südlich der Alpen. Monographie Römisch Germanischen Zentralmuseums 35. Bonn, 455-487. 
Salaš, M. 1997: Der Urnenfelderzeitliche Hortfund von Polešovice. Und die Frage der Stellung des Depotfundhorizonts in Mähren. Brno.

SALAš, M. 2005a: Bronzové depoty střední až pozdní doby bronzové na Moravĕ a ve Slezsku I. Text. Brno.

SALAŠ, M. 2005b: Bronzové depoty střední až pozdní doby bronzové na Moravĕ a ve Slezsku II. Tabulky. Brno.

SAlaš, M. - ŠMID, M. 1999: Der Bronzehortfund von Služín. Pravěk Supplementum 2, Brno.

SÁgI, J. 1909: Őstelep a Balaton partján. Archaeologiai Értesítő 29, 342-354.

Schauer, P. 1982: Deutungs-und Rekonstruktionsversuche Bronzezeitlicher Kompozitpanzer. Archäologisches Korrespondenzblatt 12, 335-349.

Schumacher-MattäUs, G. 1985: Studien zu bronzezeitlichen Schmucktrachten im Karpatenbecken. Ein Beitrag zu Deutung der Hortfunde im Karpatenbecken. Marburger Studien zur Vor-und Frühgeschichte 6. Mainz.

Sснмidt, H. 1904: Der Bronzesichelfund von Oberthau. Kr. Merseburg. Zeitschrift für Ethnologie 36, $416-452$.

Sennovitz, Gy. 1902: Geszti leletekről (Borsod m.). Archaeologiai Értesítő 22, 281-283.

ŠINKovec, I. 1995: Katalog posameznih kovinskih najdb bakrene in bronaste dobe - Catalogue of Individual Metal Finds from the Eneolithic and Bronze Ages. In: TeržAN, B. (ed.): Depojske in posamezne kovinske najdbe bakrene in bronaste dobe na Slovenskem - Hoards and Individual Metal Finds from the Eneolithic and Bronze Ages in Slovenia I. Ljubljana, 29-128.

Šimić, J. 2008. Die Bronzezeit im kontinentalen Kroatien. In: BAlen-Letunić, D. - BAder, T. STORк, S. (Hrsg.): Dreitausend Jahre Vorgeschichte. Meisterwerke der Metallzeit im kontinentalen Kroatien. Hochdorf/Enz/Eberdingen, 45-79.

Sommerfeld, C. 1994: Gerätegeld Sichel. Studien zur monetären Struktur bronzezeitlicher Horte im nördlichen Mitteleuropa. Berlin/New York.

Soroceanu, T. 1981: Der zweite Depotfund von Vîlcele, Rumanien. Praehistorische Zeitschrift 56/2, 249-261.

SoroceAnu, T. 1995: Die Fundumstande bronzezeitlicher Deponierungen - Ein Beitrag zur Hortdeutung beiderseits der Karpaten. In: Soroceanu, T. (Hrsg.): Bronzefunde aus Rumänien. Prähistorischen Archäologie in Südosteuropa 10. Berlin, 17-75.

Soroceanu, T. 2008: Die vorskythenzeitlichen Metallgefäße im Gebiet des heutigen Rumänien - Descoperiri de Bronzuri din România. Berlin.

SőREGI, J. 1930: Régészeti kutatások és ásatások 1930-ban. Debreceni Déri Múzeum évkönyve 21, 67-85.

SőTÉR, A. 1892: Mosony-Szolnok és mosony-jeselhofi bronzkori leletek. Archaeologiai Értesítő 12, 207-212.

Speciale, C. - Zanini, A. 2010: Cinceles en la Edad del Bronce italiana: aspectos technológicos y tipológicos. Trabajos de Prehistoria 67, 419-430.

SprocкноғF, E. 1941: Niedersachsens Bedeutung für der Bronzezeit Westeuropas. Zur Verankerung einer neuen Kulturprovinz. Bericht der Römisch-Germanischen Komission 31, 1-155.

Sprocкhoff, E. 1956: Jungbronzezeitliche Hortfunde. Der Südzone des Nordischen Kreises. (Periode V) 1. Mainz.

Sydow, W. 1995: Der Hallstattzeitliche Bronzehort von Fliess im Oberinntal, Tirol. Fundberichte aus Österreich Materialheft A/3. Wien. 
SzABó, G. 1993: Fémmegmunkálási nyomok a Regöly-Veravár késő bronzkori leletegyüttes tárgyain. Wosinsky Mór Múzeum Évkönyve 18, 169-224.

SzABó, G. 1996: The manufacture and useage of Late Bronze Age rings: two new hoards. In: Kovács, T. (Hrsg.): Studien zur Metallindustrie im Karpatenbekcen und den benachbarten Regionen. Festschrift für Amália Mozsolics zum 85. Geburtstag. Budapest, 207-230.

SzABó, G. 2013: A Dunántúli Urnamezős Kultúra Fémmúvessége az Archaeometallurgiai Vizsgálatok Tükrében. - The Metallurgy of the Transdanubian Urnfield Culture in Light of Archaeometallurgical Investigations. Pécs.

V. SzABó, G. 2009: Fémkereső műszeres kutatások kelet-magyarországi késő bronzkori és kora vaskori lelőhelyeken - Metal detection investigations at Eastern Hungarian Late Bronze Age and Early Iron Age sites. Régészeti Kutatások Magyarországon, 19-38.

V. Szabó, G. 2011: Spätbronzezeitliche Bronzehortfunde im Siedlungskontext - Neue Forschungsergebnisse aus Ostungarn. In: Berecki, S. - Németh, R. E. - Rezi, B. (eds.): Bronze Age Rites and Rituals in the Carpathian Basin. Târgu Mureş, 2011. Târgu Mureş, 335-356.

V. SzABó, G. 2013: Late Bronze Age Stolen. New Data on Illegal Acquisition and Trade of Bronze Age Artefacts in the Carpathain Basin. In: Anders, A. - Kulcsár, G. - Kalla, G. - Kiss, V. - V. SzABó, G. (eds.): Moments in Time. Papers Presented to Pál Raczky on His $60^{\text {th }}$ Birthday. Budapest, 793-815.

V. SzABó, G. - Bíró, P. 2009: Őskori magaslati erődített település Bükkzsérc-Hódos-tetőn. Előzetes jelentés a lelőhelyen végzett kutatásokról. Ösrégészeti Levelek - Prehistoric Newsletter 11, 72-84.

SzÁnTó, I. 1947: A Gyöngyössolymos-Kishegyi Koravaskori Bronzlelet. Magyar Múzeum, 1-8.

Szentmártoni Darnay, K. 1899: Sümegh vidékének őskora. Archaeologiai Közlemények 22, 19-26.

Szentmártoni Darnay, K. 1905: Fonyódi úrnasírról. Archaeologiai Értesítő 25, 160-161.

SzentmÁrtoni Darnay, K. 1910: Az Uzsavölgyi bronzkincs. Archaeologiai Értesítő 30, 426-431.

SzILAS, G. 2003: Késő bronzkori karikalelet a Dunából - Spätbronzezeitlicher Ringfund aus der Donau. Communicationes Archaeologicae Hungariae, 67-75.

Tarbay, J. G. 2011: Későbronzkori depó Kesztölcről. A feldolgozás első lépései. Unpublished BA-thesis. Budapest.

Tarbay, J. G. 2012: Újabb paszományos fibulák a Dunántúlról: Kesztölc és Dunaújváros. - New passementerie fibulae from Kesztölc and Dunaújváros in Transdanubia. Ösrégészeti Levelek Prehistoric Newsletter 12, 115-136.

Tarbay, J. G. 2013: Dunántúli későbronzkori depóegyüttesek elemzése: Kesztölc és Nagydobsza. Unpublished MA-thesis. Budapest.

Tarot, T. 2000: Die bronzezeitlichen Lanzenspitzen des Schweiz unter Einbeziehung von Lichtenstein und Vorarlberg. Universitätsforschungen zur Prähistorischen Archäologie 66. Bonn.

TARot, T. 2000: Die bronzezeitlichen Lanzenspitzen des Schweiz unter Einbeziehung von Lichtenstein und Vorarlberg. Universitätsforschungen zur Prähistorischen Archäologie 66. Bonn.

TÉGLÁs, G. 1885: Praehistorikus arany- vas, és kőbányászati eszközök Dáciában. Archaeológiai Közlemények 14, 106-115.

TÉGLÁs, G. 1887: Őskori nemes fémbányászatunk némely adalékai. Erdélyi Múzeum, 116-152.

TÉGLÁs, G. 1891: Újabb adatok a verespataki bányászat legrégibb történetéhez - Neuere Daten zur altesten Geschichte der Verespataker Berghauer. Földtani Közlöny 21, 181-184. 
TeRžAn, B. 1999: An Outline of the Urnfield Culture Period in Slovenia. Arheološki vestnik 50, 97-143.

TERŽAN, B. 2000: Bronzezeit und älteren Eisenzeit im östlichen Mitteleuropa zum Mittelmeergebiet. In: Beck, H. (Hrsg.): Fibel und Fibeltracht. Reallexikon der Germanischen Altertumskunde 8. Berlin, 34-46.

TомрA, F. 1923-1926: Velemszentvid bronzöntő ipara. Az Országos Magyar Régészeti Társulat Évkönyve 2, 41-53.

TöRöк, Gy. 1940: A Lengyelótiban előkerült bronzlelet. - Der Bronzefund aus Lengyeltóti. Dolgozatok $16,57-67$.

Trogmayer, O. 1975: Das Bronzezeitliche Gräberfeld von Tápé. Fontes Archaeologici Hungariae. Budapest.

TRŇÁčKovÁ, Z. 1965: Dva hromadné nálzey bronzových predmětů z Uničovska - Zwei Bronzehortunde aus der Umgebung von Uničov. Olomouc.

Turk, P. 1996: The Dating of Late Bronze Age Hoards. - Datacija poznobronastodobnih depojev. In: TERŽAN, B. (ed.): Depojske in posamezne kovinske najdbe bakrene in bronaste dobe na Slovenskem. Hoards and Individual Metal Finds from the Eneolithic and Bronze Ages in Slovenia. Ljubljana, 89-124.

UnDSET, I. 1880: Études sur l'Age de bronze de la Hongrie. Christiania.

UnDSET, I. 1884: Az oroszi lelet és a magyarországi bronzleletek. Archaeologiai Értesítő 4, 231-233.

VÁczI, G. 2014: A sióagárd-leányvári kincslelet. Megjegyzések a gyermelyi horizont időrendjéhez The hoards from Sióagárd-Leányvár. Notes on the chronology of the Gyermely horizon. In: Anders, A. - BAlogh, Cs. - Türk, A. (eds.): Avarok pusztái. Régészeti tanulmányok Lórinczy Gábor 60. születésnapjára - Avarum Solitudines. Archaeological studies presented to Gábor Lörinczy on his sixtieth birthday. Budapest, 43-57.

VAsIĆ, R. 1982: Spätbronzezeitliche und älterhallstattzeitliche Hortfunde im östlichen Jugoslawien. In: Hänsel, B. (ed.): Südosteuropa zwischen 1600 und 1000 v. Chr. Berlin, 267-285.

VAsIć, R. 1994: Die Sicheln im Zentralbalkan. (Vojvodina, Serbien, Kosovo und Mazedonien). Prähistorische Bronzefunde 18/5. Stuttgart.

VAsić, R. 1999: Die Fibeln im Zentralbalkan (Vojvodina, Serbien, Kosovo und Mazedonien). Prähistorische Bronzefunde 14/12. Stuttgart.

VAsIć, R. 2010: Die Halsringe im Zentralbalkan. (Vojvodina, Serbien Kosovo und Mazedonien). Prähistorische Bronzefunde 11/7. Stuttgart.

VÁsÁrhelyi, I. 1889: A gyermeli bronzleletről. Archaeologiai Értesítő 9, 61-66.

VINSKi-GASPARINI, S. 1973: Kultura polja sa žarama u sjevemoj Hrvatskoj - Die Urnenfelderkultur in Nordkroatien. Zadar.

WaGner, S. Nordtiroler Urnenfelderzeit. Römisch-Germanische Forschungen 15. Berlin.

WanzeK, B. 1989: Die Gußmodel für Tüllenbeile im südöstlichen Europa. Universitätsforschung zur prähistorischen Archäologie 2. Bonn.

WanzeK, B. 1992: Der älturnenfelderzeitliche Hortfund von Lengyeltóti („Lengyeltóti II”) Komitat Somogy, Ungarn. Eine Vorlage. Acta Praehistorica et Archaeologica 24, 249-288.

WanZeK, B. 2002: Zur Syntax der Muster auf Griffzungensicheln im bronzezeitlichen Südosteuropa. European Archaeology - online. Feb. 2002, 1 - 43. (www.archaeology.ro/bwan.htm). 
Wels-Weyrauch, U. 1978: Die Anhänger und Halsringe in Südwestdeutshland und Nordbayern. Prähistorische Bronzefunde 11/1. München.

Willvonseder, K. 1935: Zur Datierung des bronzegürtels von Tetétlen. Dolgozatok Szeged 11, 22-226.

Willvonseder, K. 1937: Die mittlere Bronzezeit in Österreich. Bücher zu Ur-und Frühgeschichte 3. Wien-Leipzig.

WindholZ-KonRad, M. 2008: Ein prähistorische Depotfund vom Brandgraben im Kainischtal, Steiermark. Schätze. Gräber. Opferplätze. Traunkirchen 08. Archäologie im Salzkammergut. Fundberiche aus Österreich Materialheft A, Sonderheft 6, 48-54.

Windholz-Konrad, M. - Preßlinger, H. 2005: Die Rabenwand - ein neuer prahistorischer Depotfundplazt im Ausseerland, Steiermark. Fundberichte aus Österreich 43, 289-349.

Wosinsky, M. 1896: Tolnavármegye az őskortól a honfoglalásig I. Budapest.

ZacCAGnini, C. 1977: Pferde und Streitwagen in Nuzi. Jahresbericht des Instituts für Vorgeschichte der Universität Frankfurt am Main, 21-38.

ŽeravicA, Z. 1993: Äxte und Beile aus Dalmatien und anderen Teilen Kroatiens, Montenegro, Bosnien und Herzegowina. Prähistorische Bronzefunde 9/18. Stuttgart.

ZiEgerT, H. 1964: Archäologie und Ethnologie. Zur Zusammenarbeit zwier Wissenschaften. Berliner Jahrbuch für Vor-und Frühgeschichte 4, 102-149. 


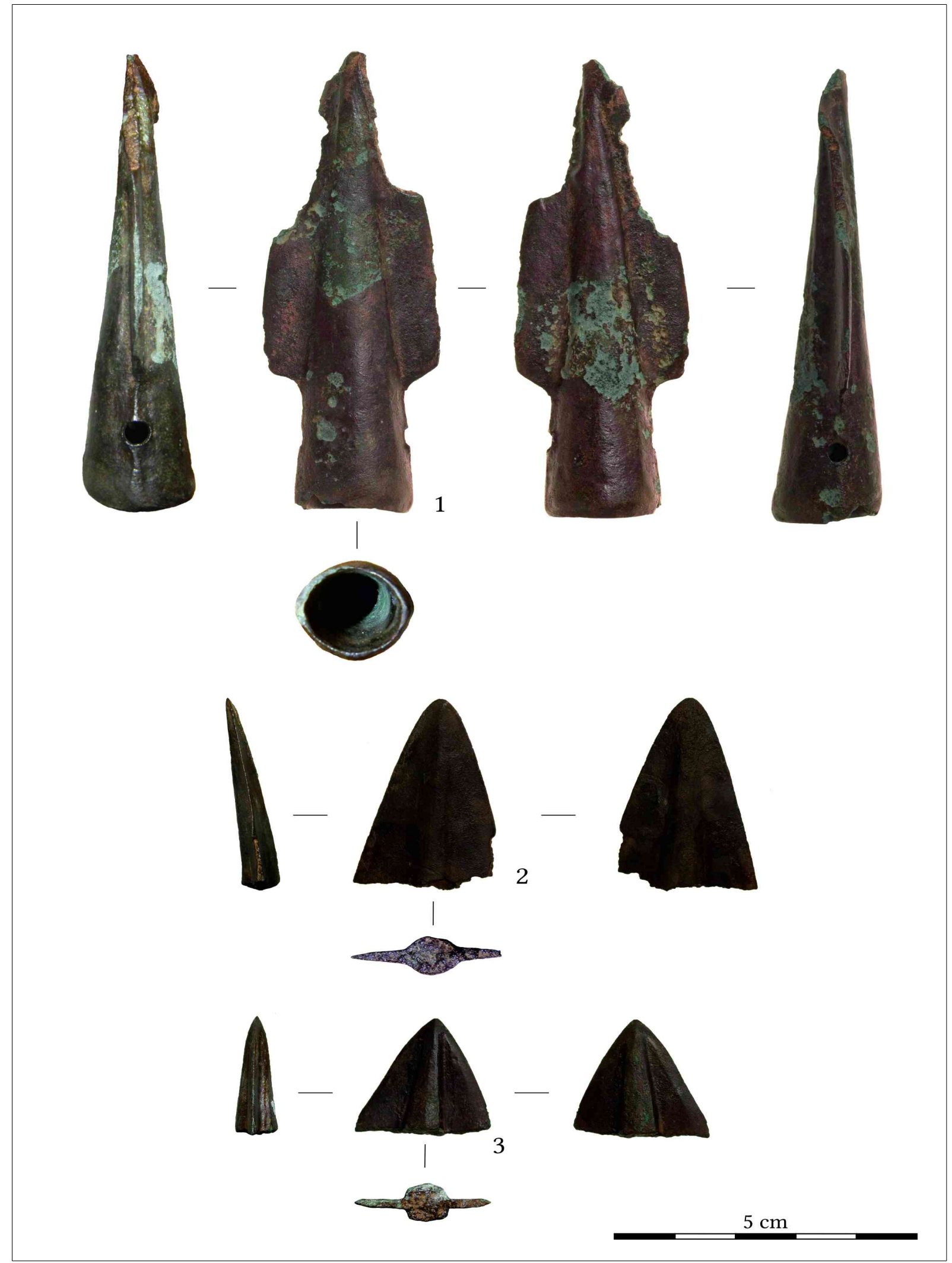

Fig. 45. 1-3. Spear and spear fragments. 


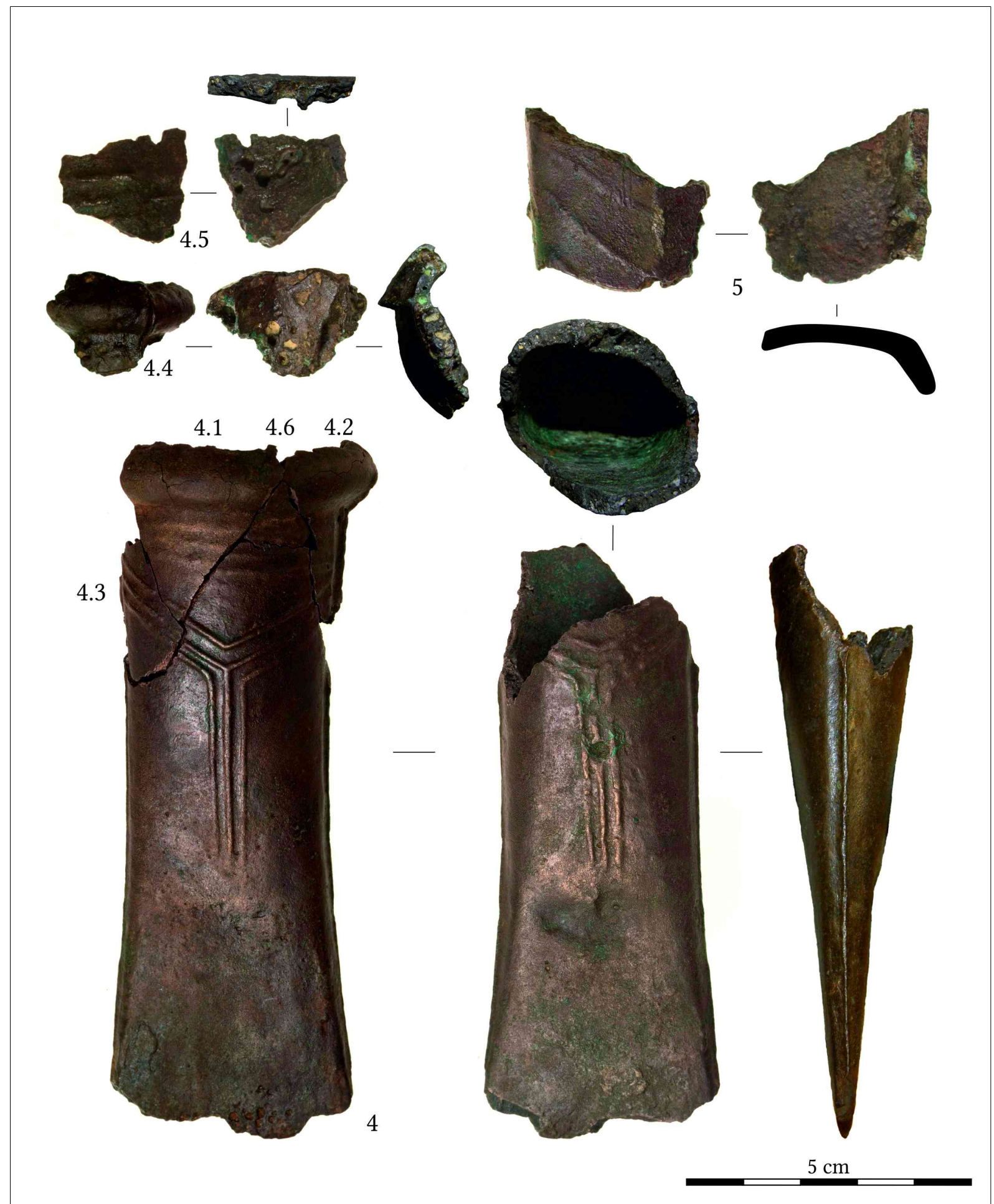

Fig. 46. 4-5. Socketed axes. 


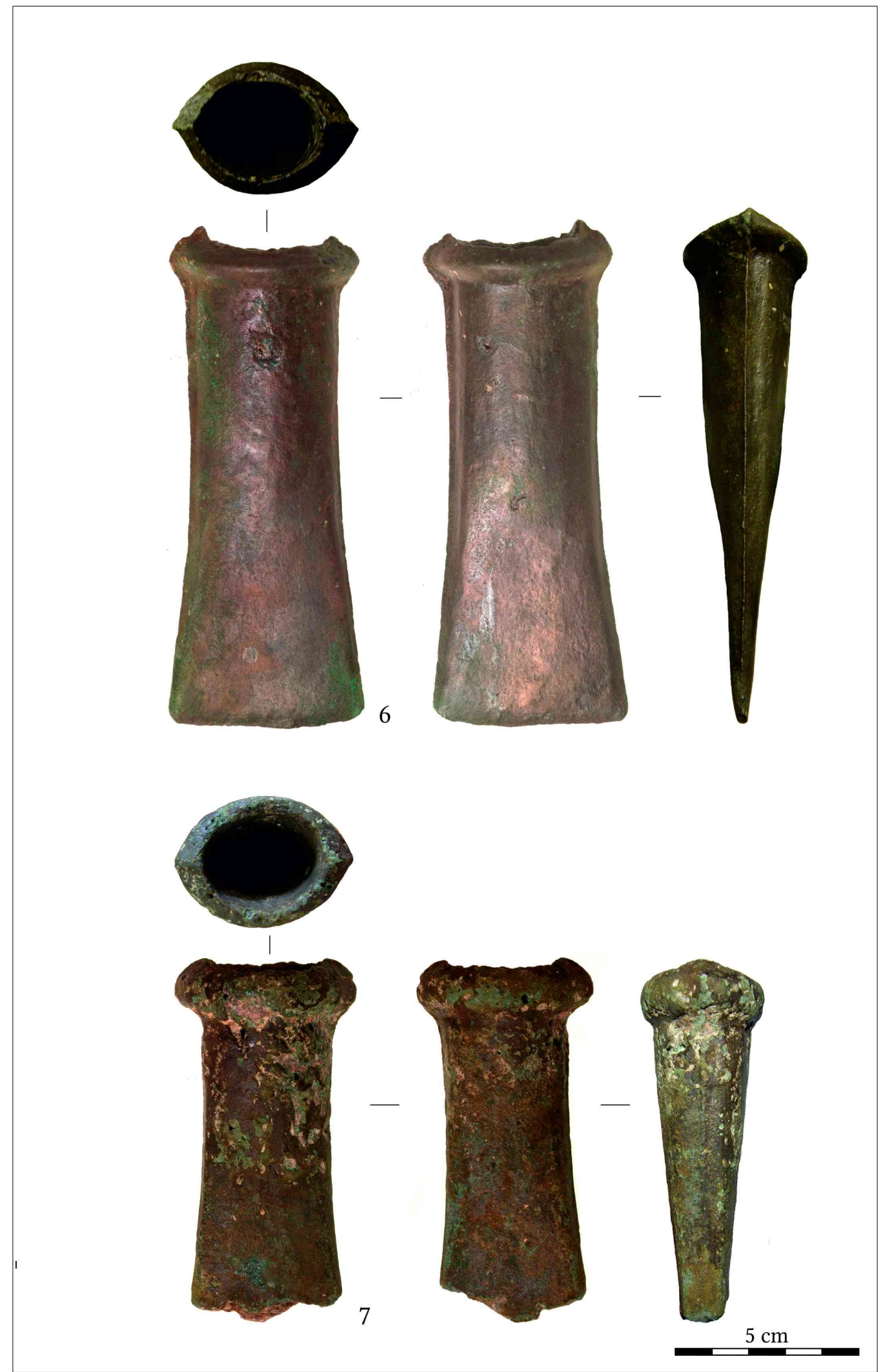

Fig. 47. 6-7. Socketed axes. 


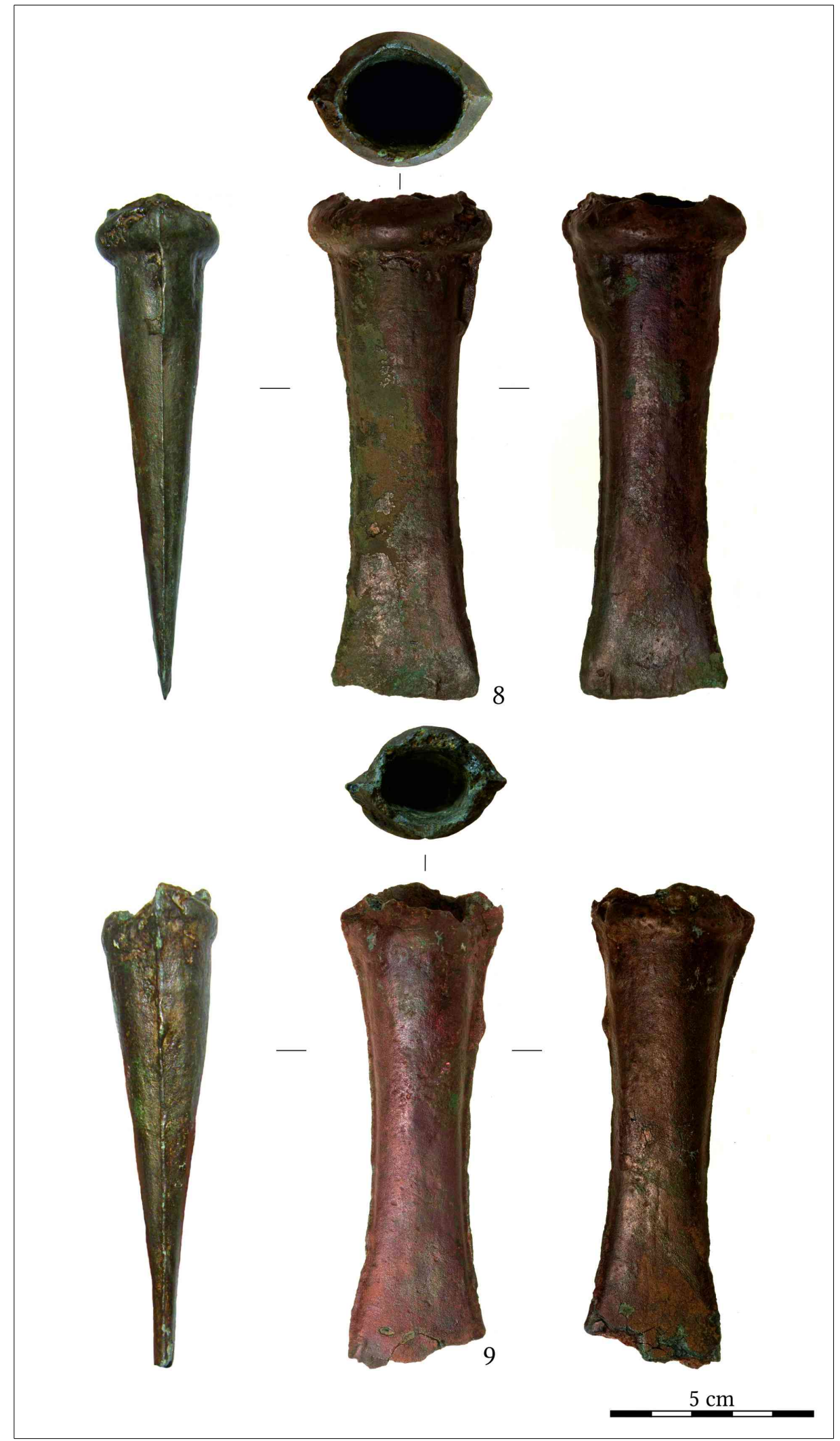

Fig. 48. 8-9. Socketed axes. 


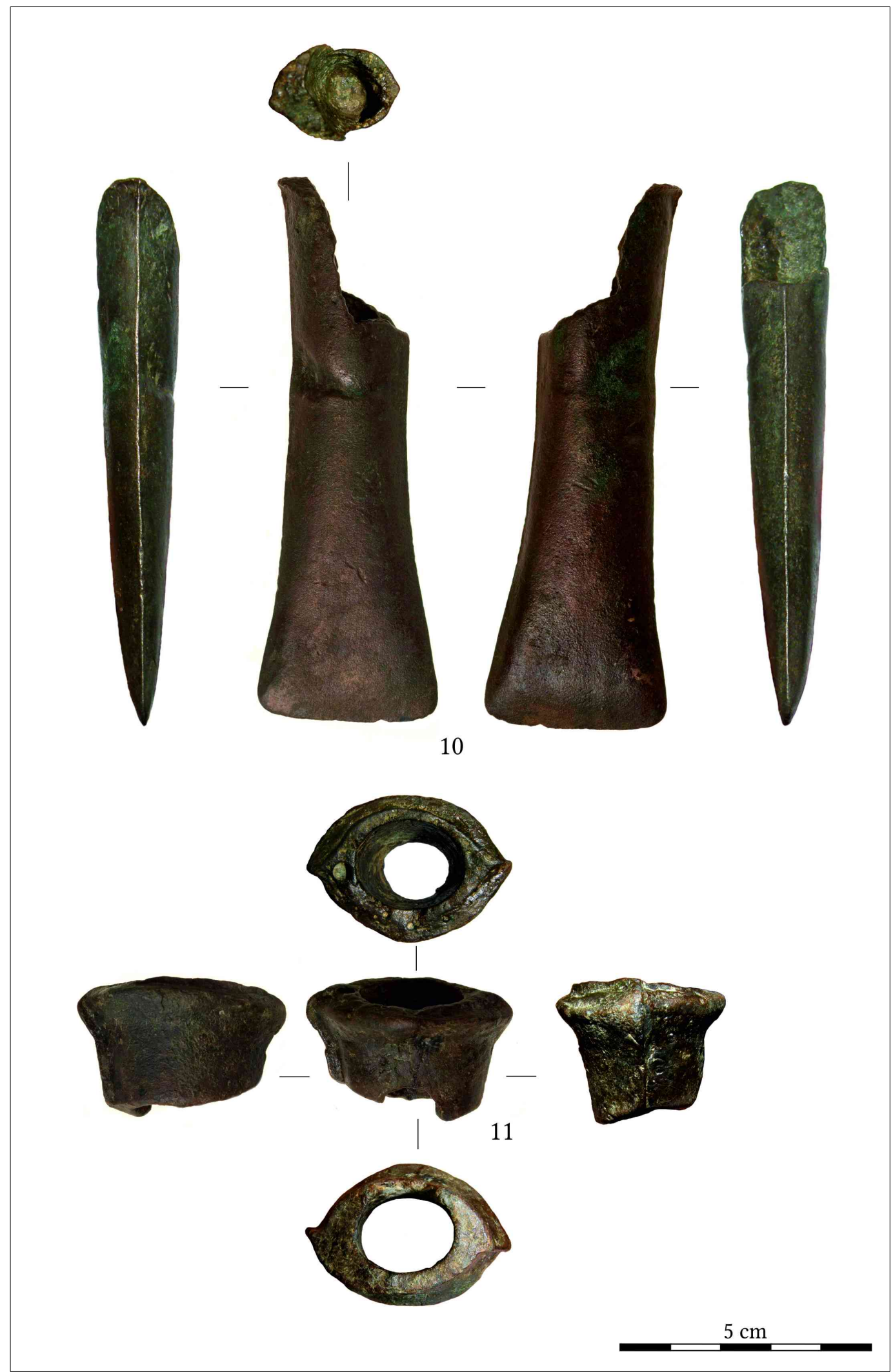

Fig. 49. 10-11. Socketed axes. 


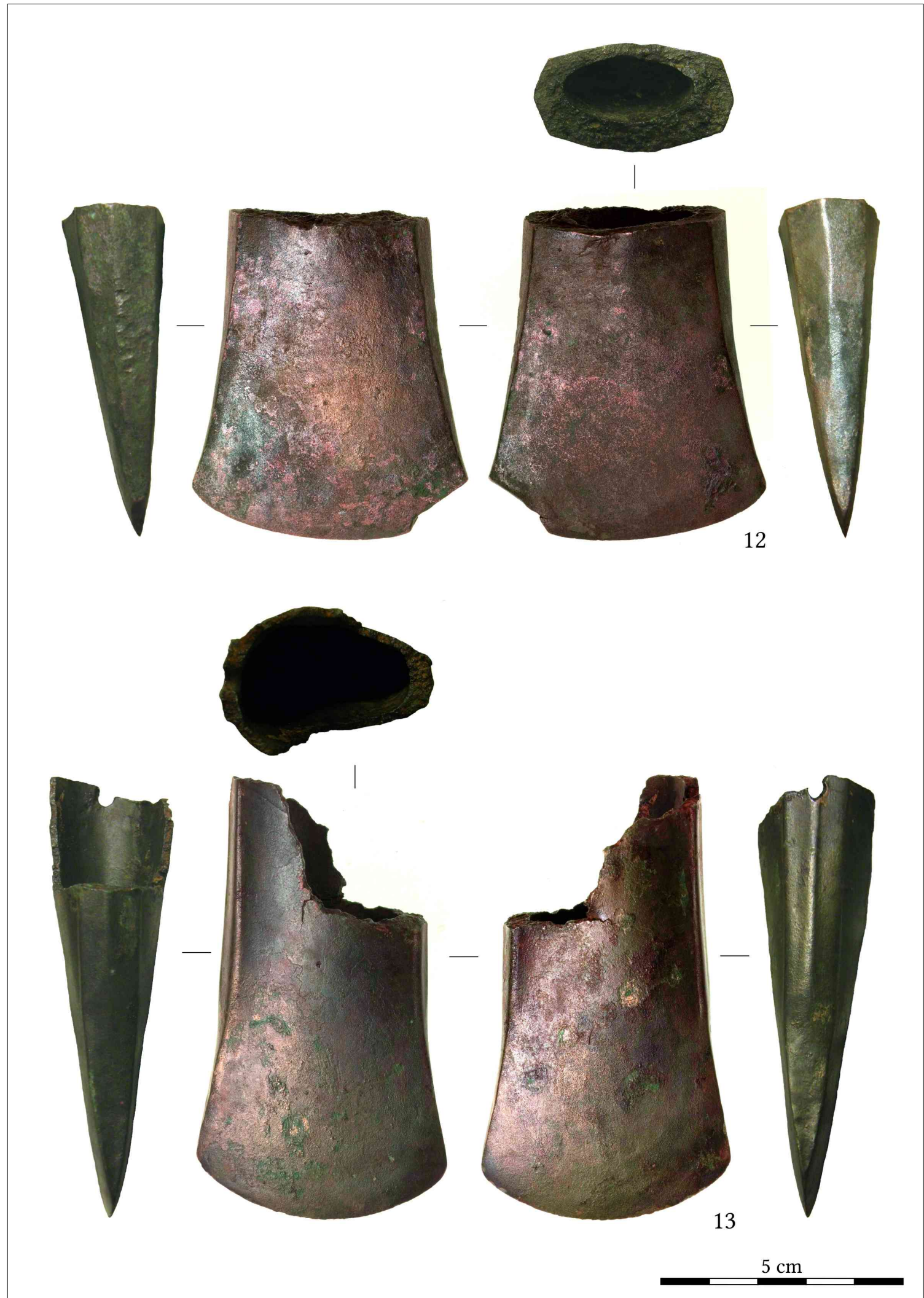

Fig. 50. 12-13. Socketed axes. 


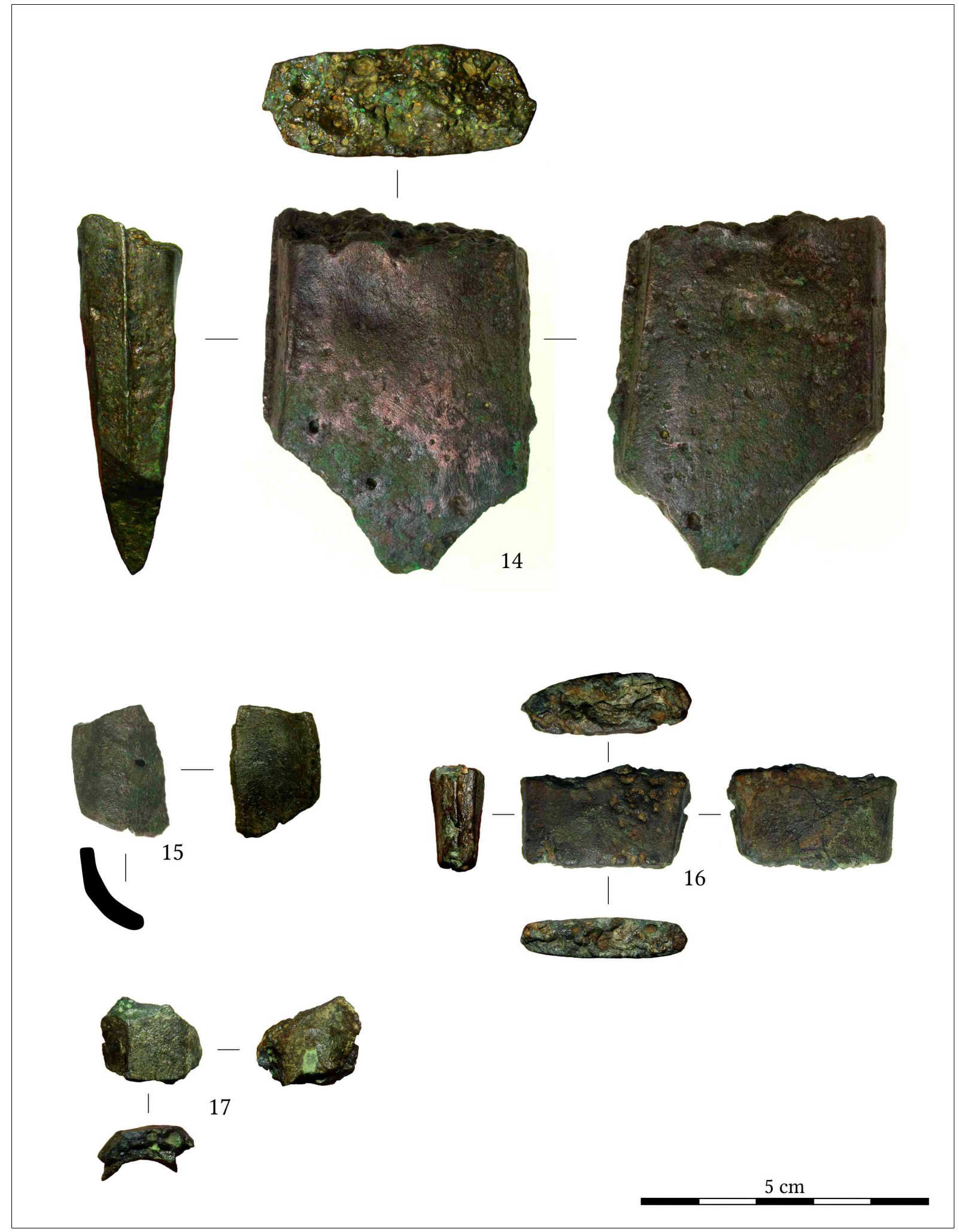

Fig. 51. 14-17. Socketed axes. 


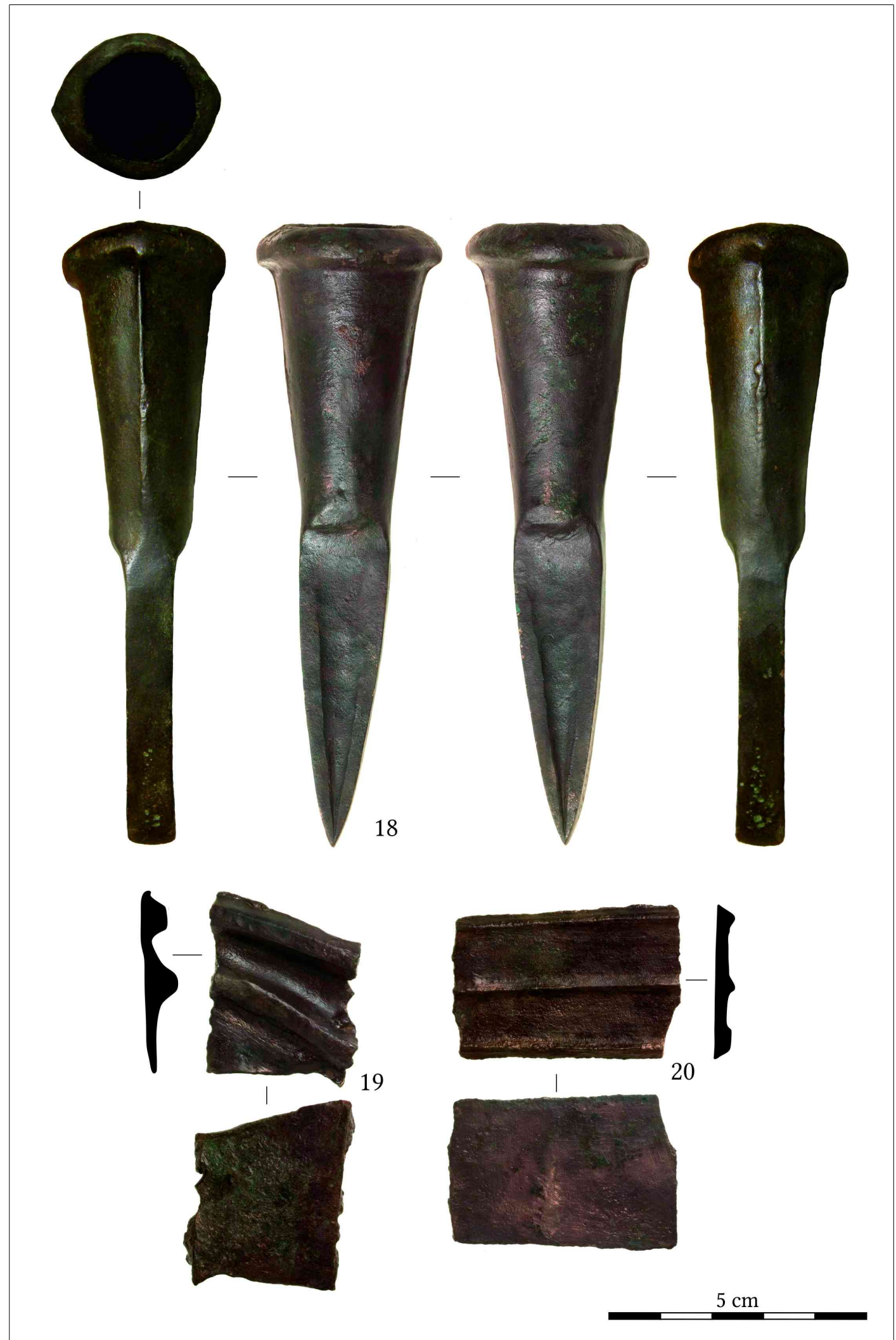

Fig. 52. 18. Socketed chisel 19-20. Flange-handled sickle fragments. 
J. G. TARbAY: Late Bronze Age depot from the foothills of the Pilis Mountains

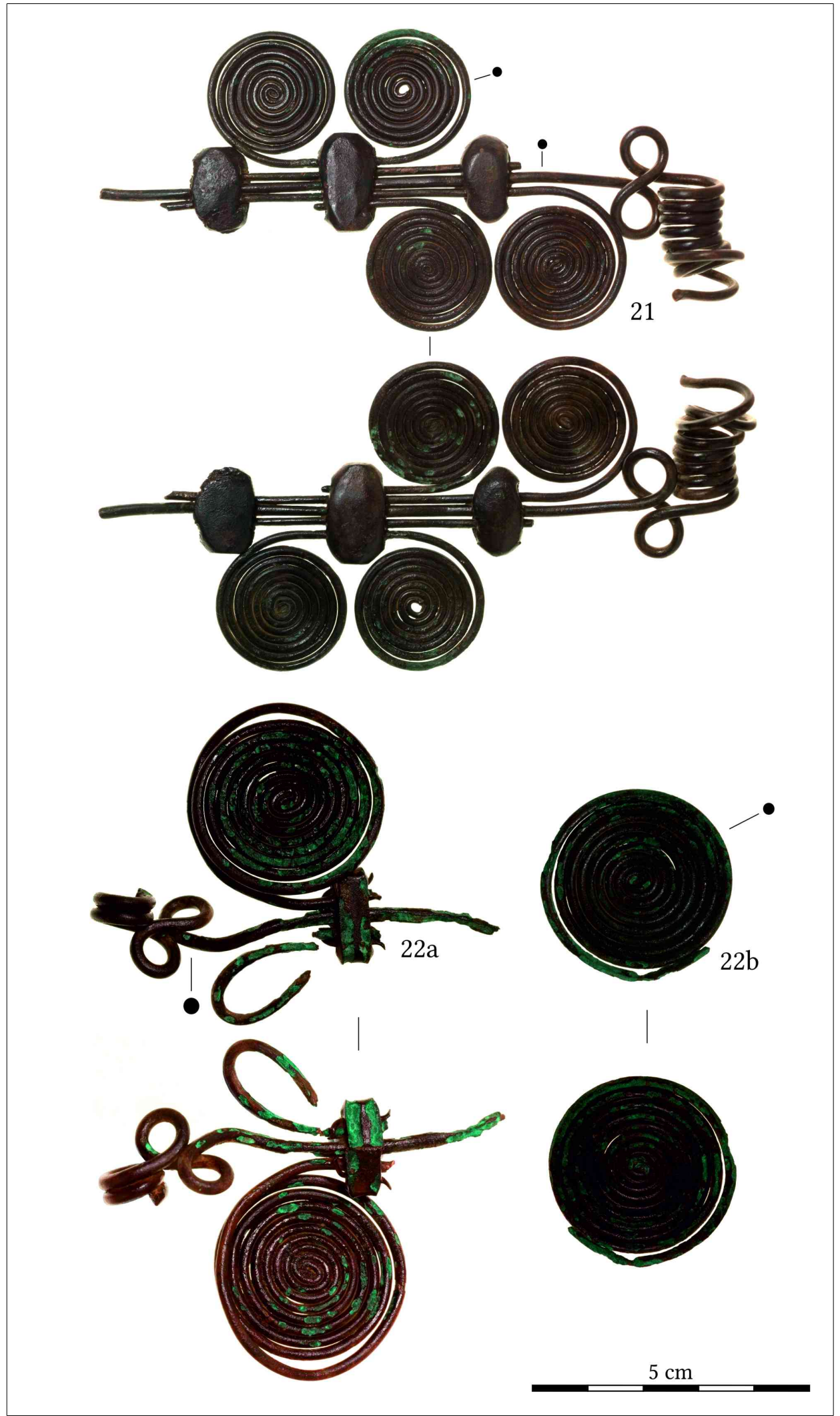

Fig. 53. 21-22a. Passementerie fibulae. 


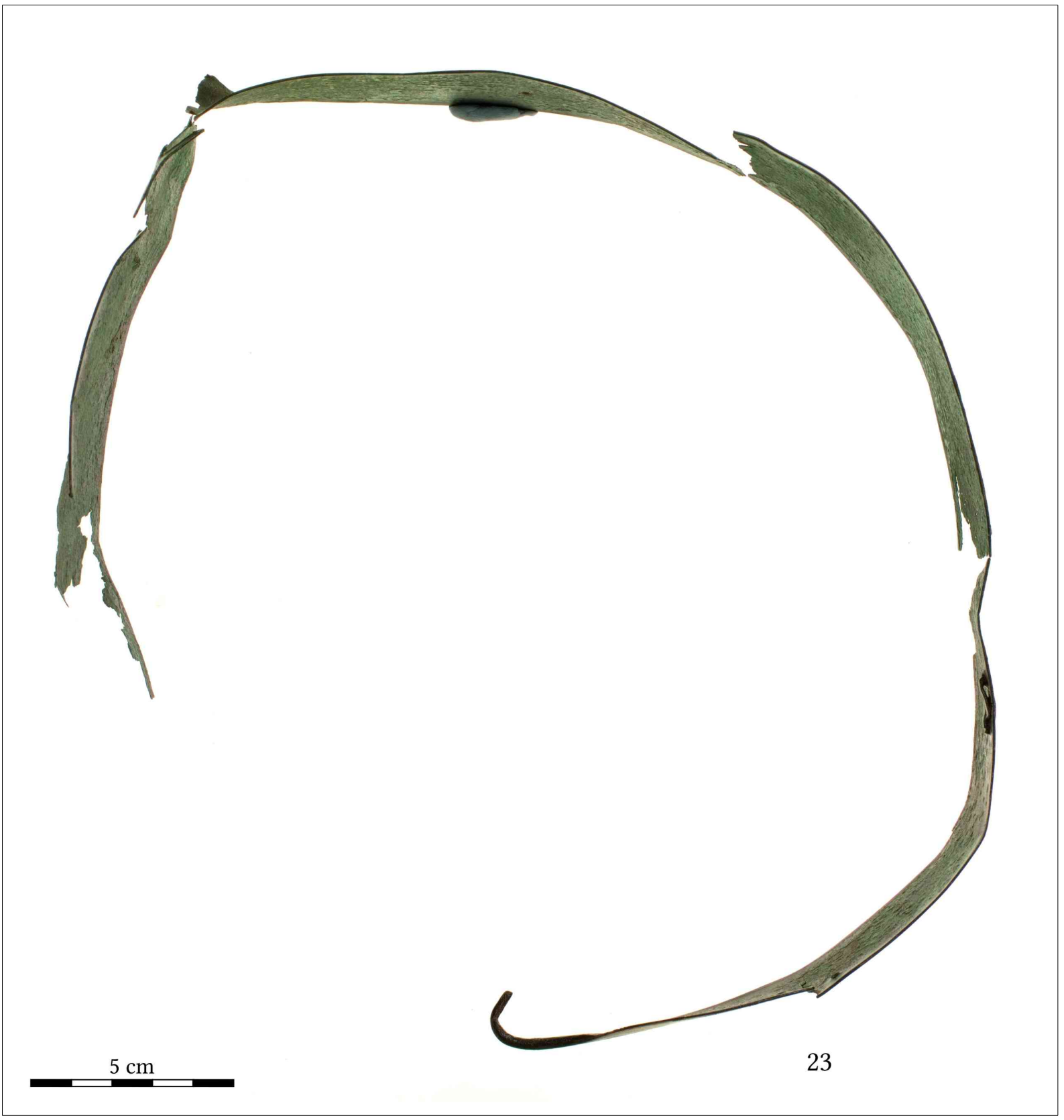

Fig. 54. 23. The reconstructed belt. 


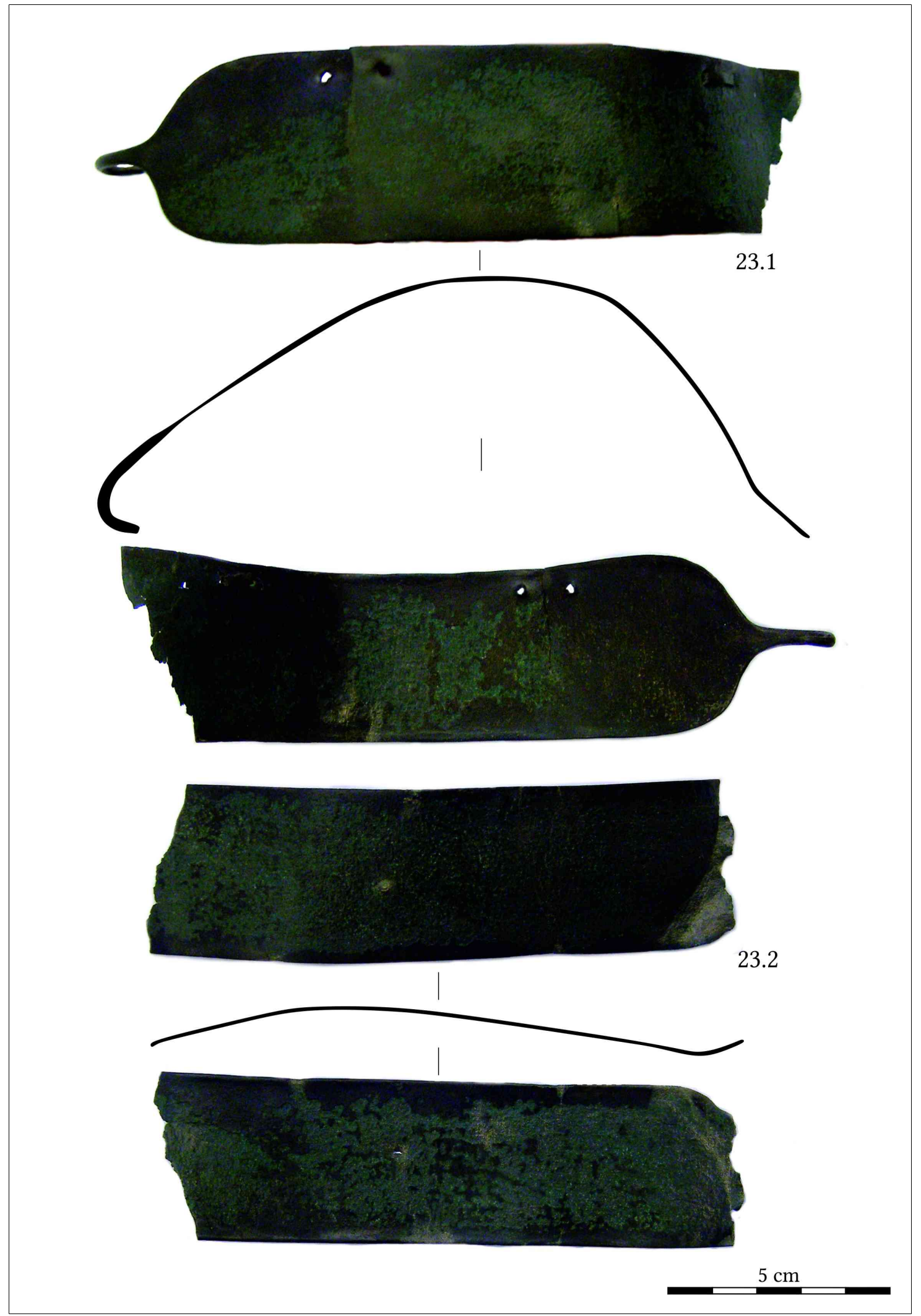

Fig. 55. 23.1-23.2. Fragments of the belt. 
J. G. TARBAY: Late Bronze Age depot from the foothills of the Pilis Mountains

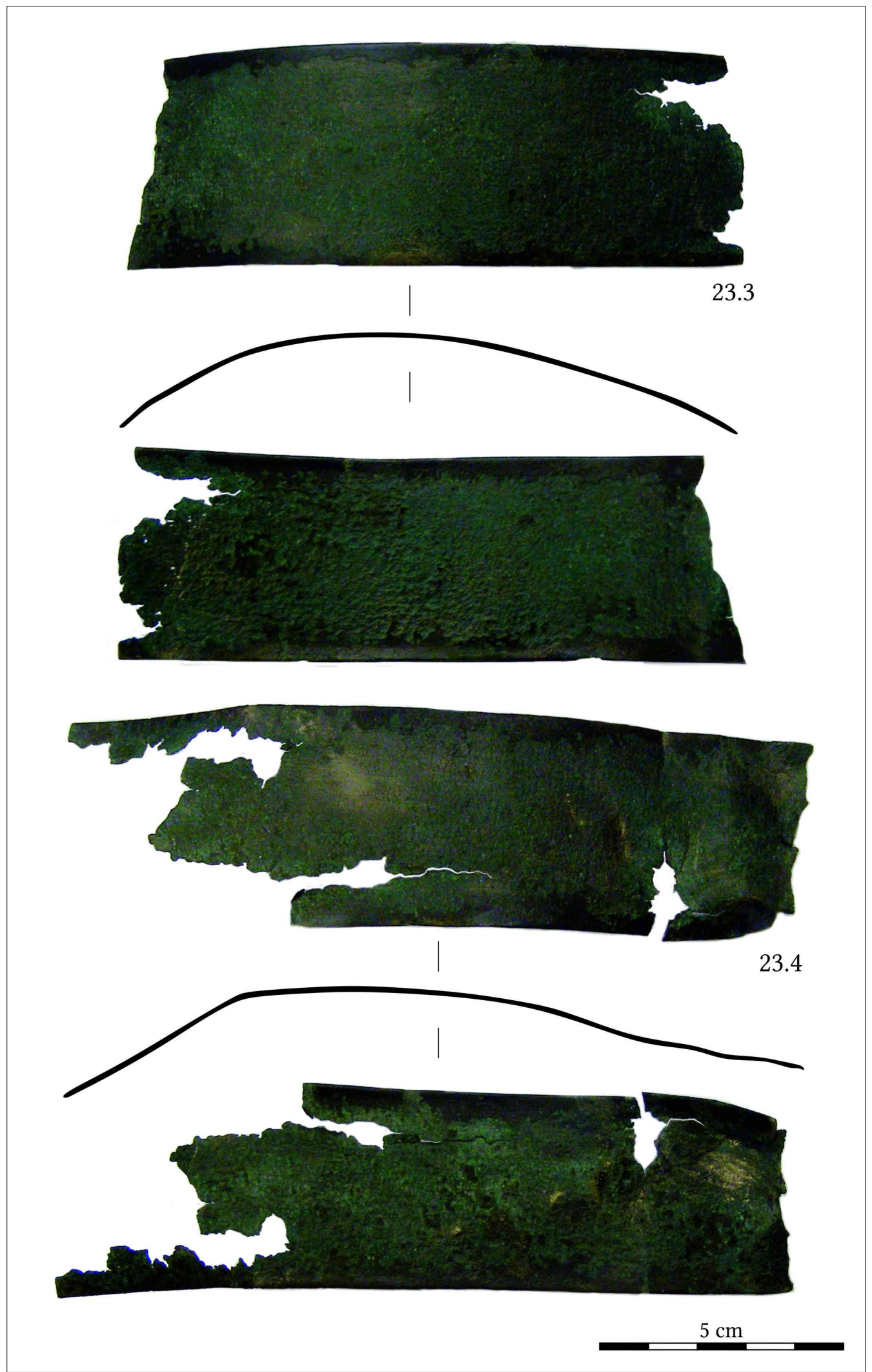

Fig. 56. 23.3-23.4 Fragments of the belt. 
J. G. TARBAY: Late Bronze Age depot from the foothills of the Pilis Mountains

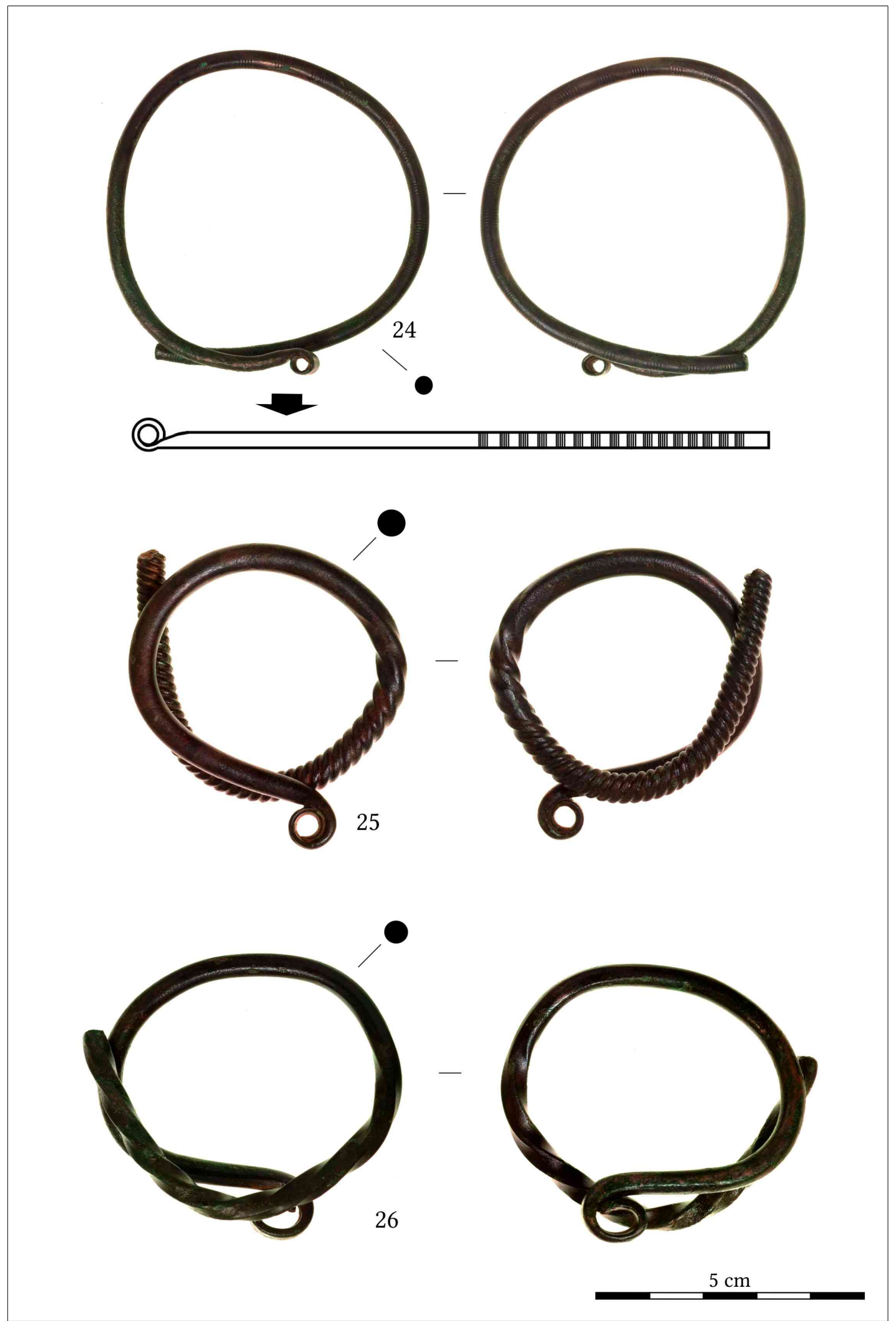

Fig. 57. 24-26. Torques fragments. 


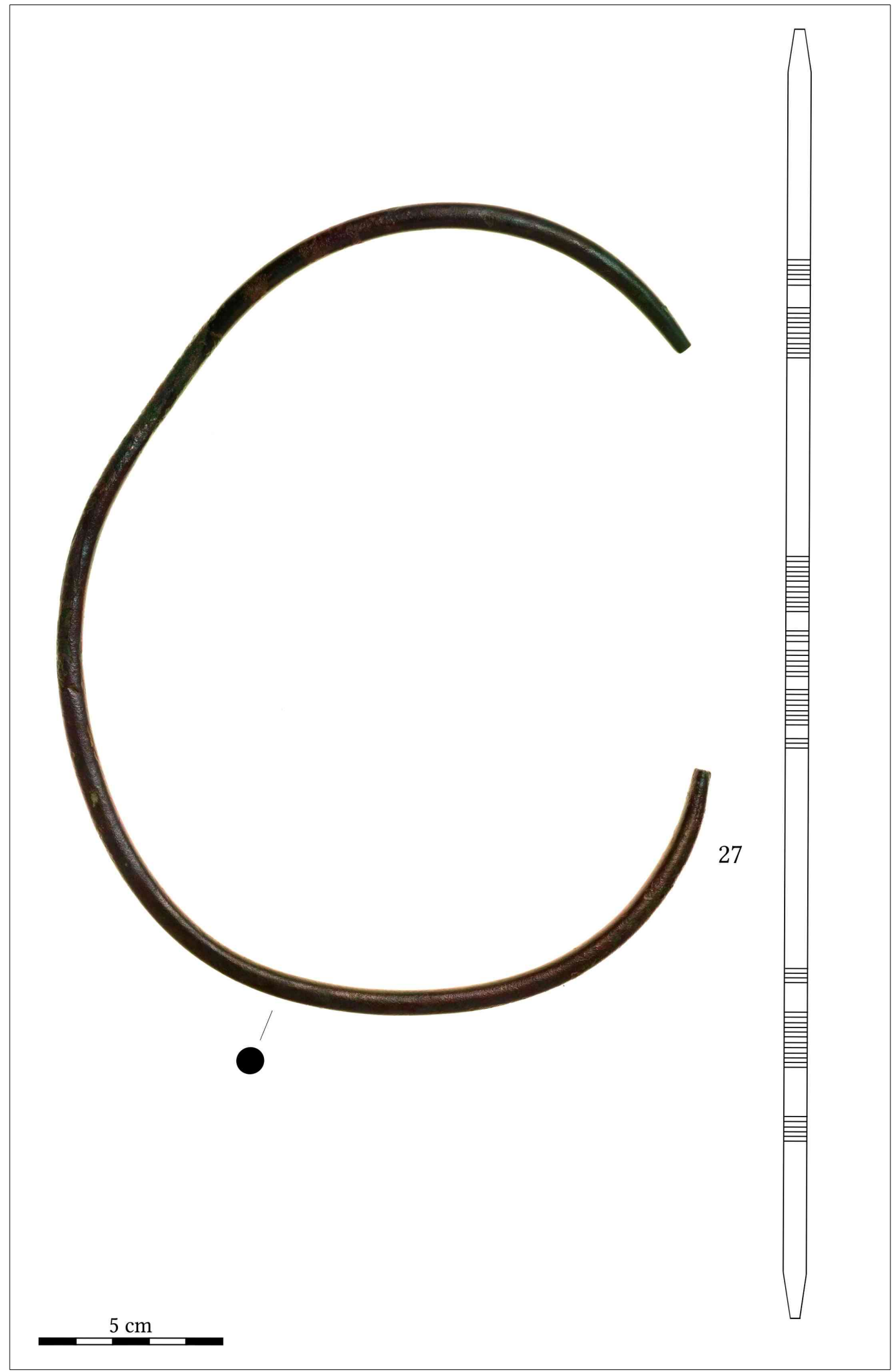

Fig. 58. Round-sectioned ring with line decoration. 


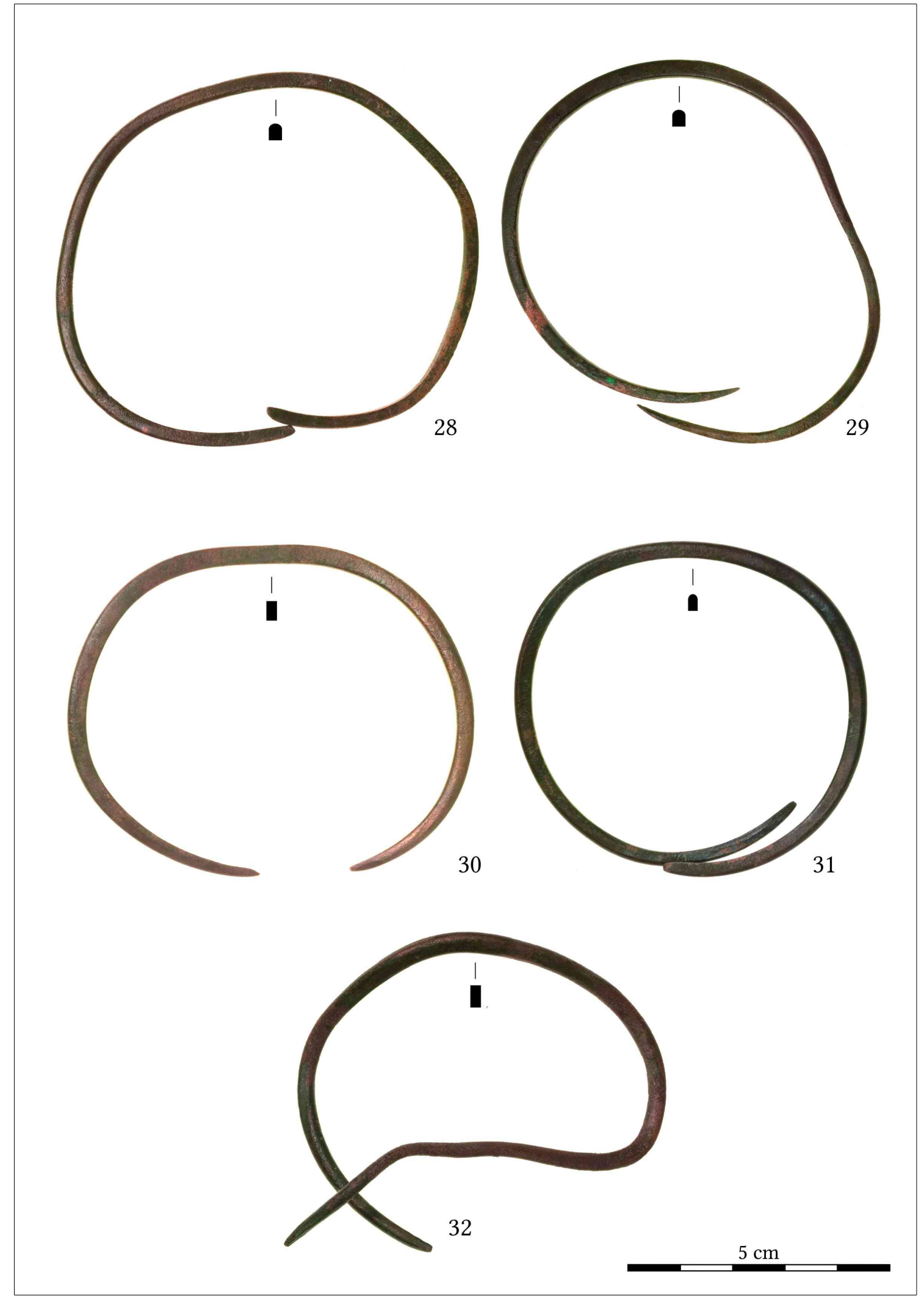

Fig. 59. 28-32. Rings with pointed-terminals. 

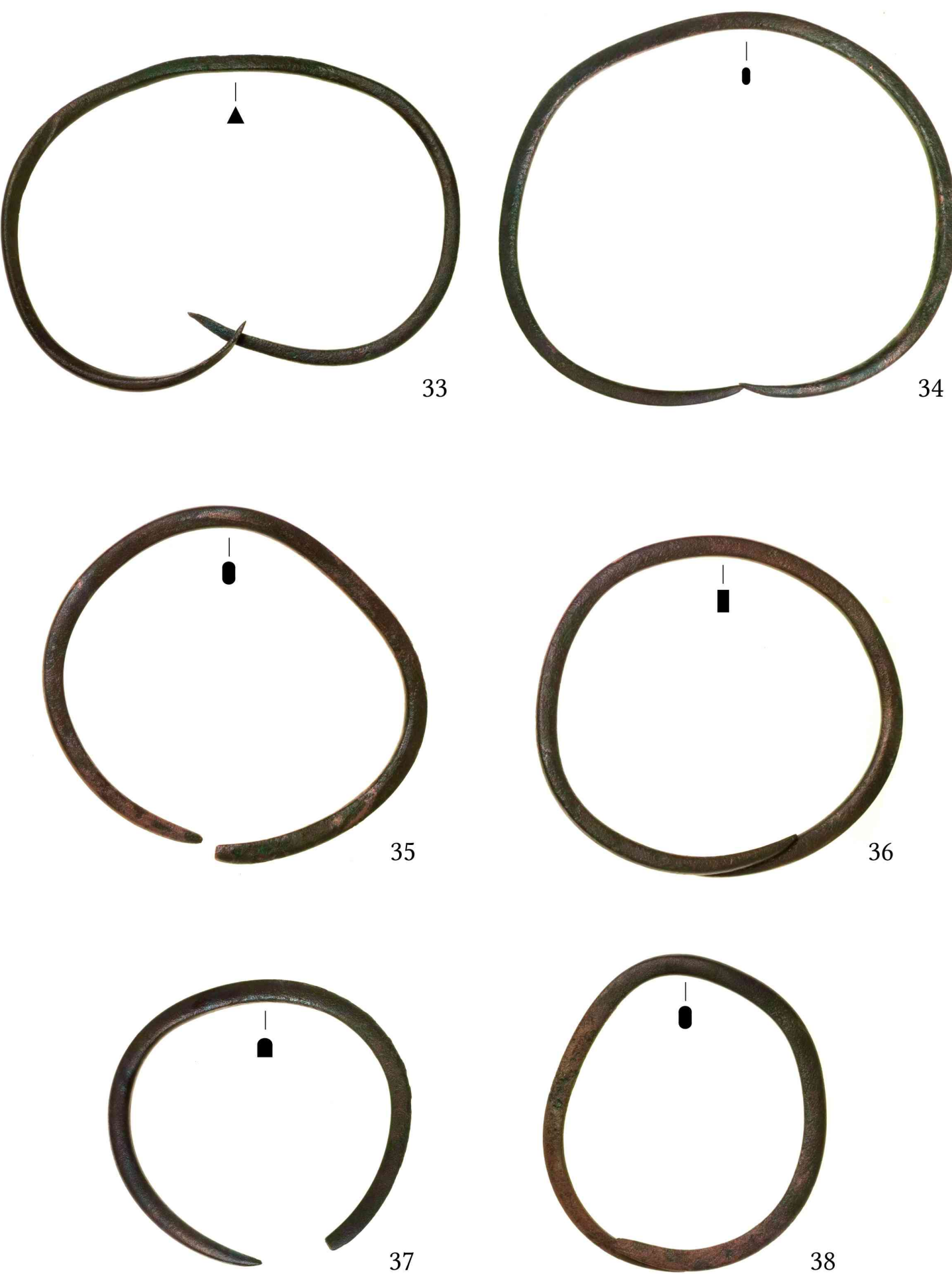

$5 \mathrm{~cm}$

Fig. 60. 33-38 Rings with pointed-terminals. 

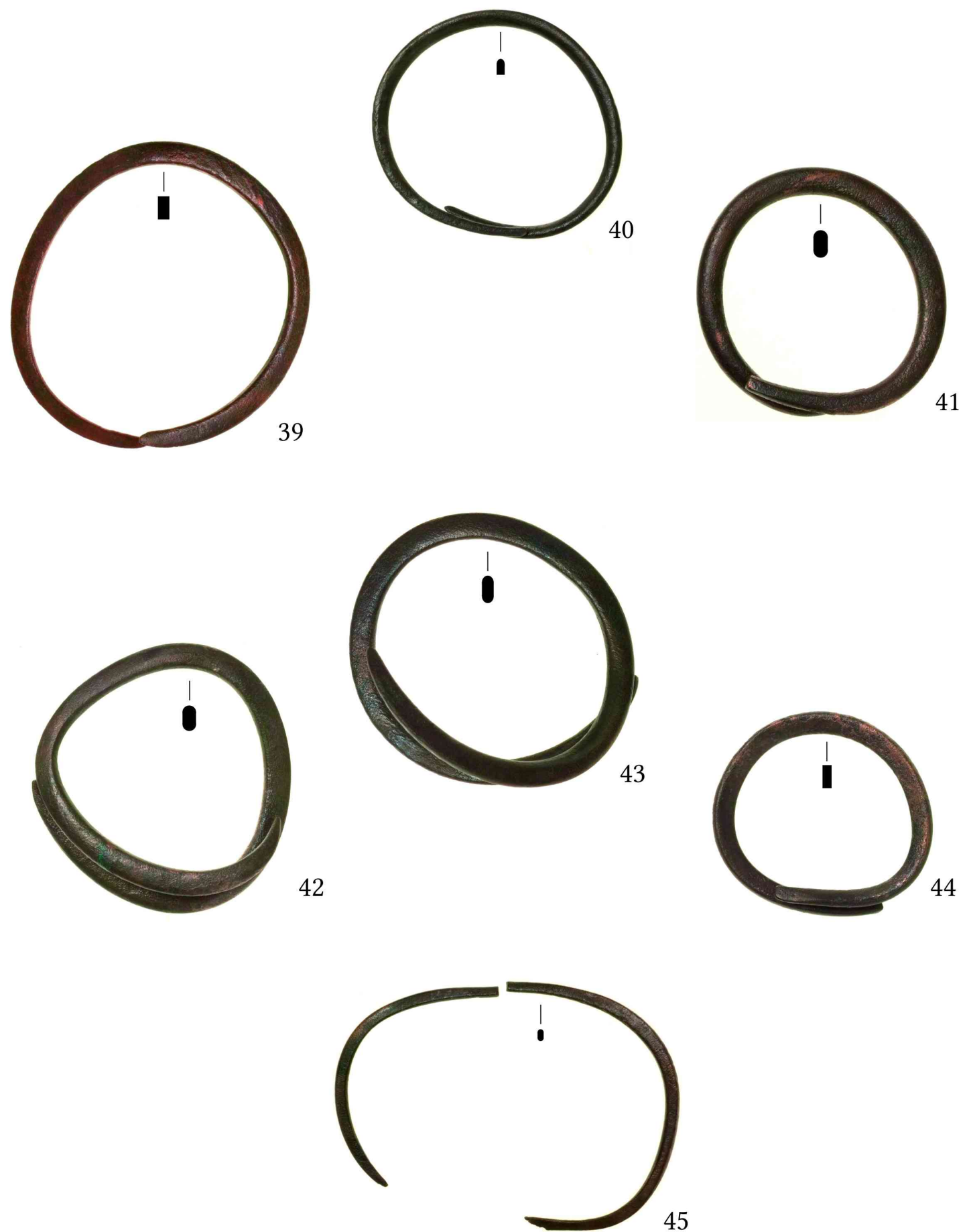

$5 \mathrm{~cm}$

Fig. 61. 39-45. Rings with pointed-terminals. 


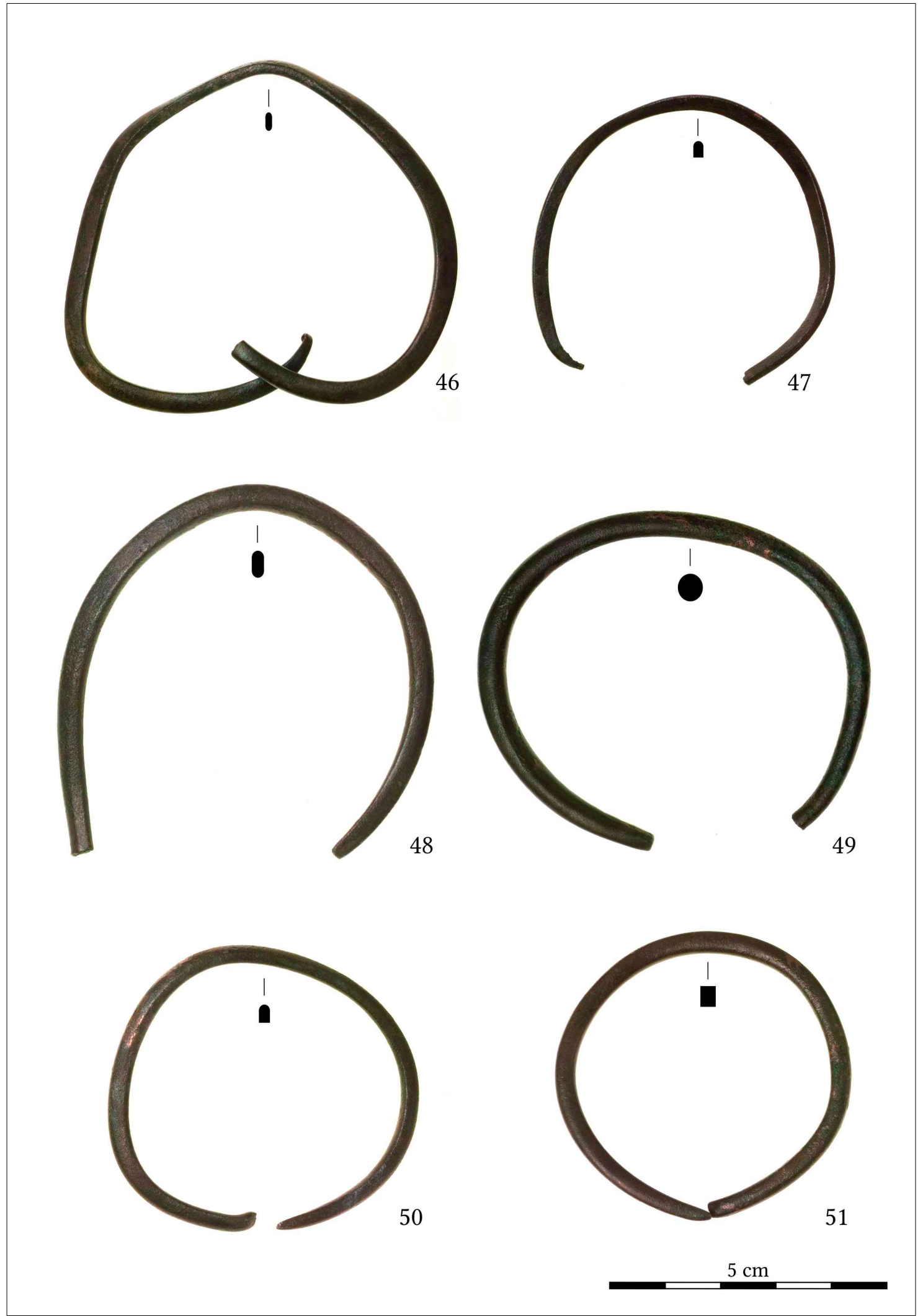

Fig. 62. 46-51. Rings with pointed-terminals. 


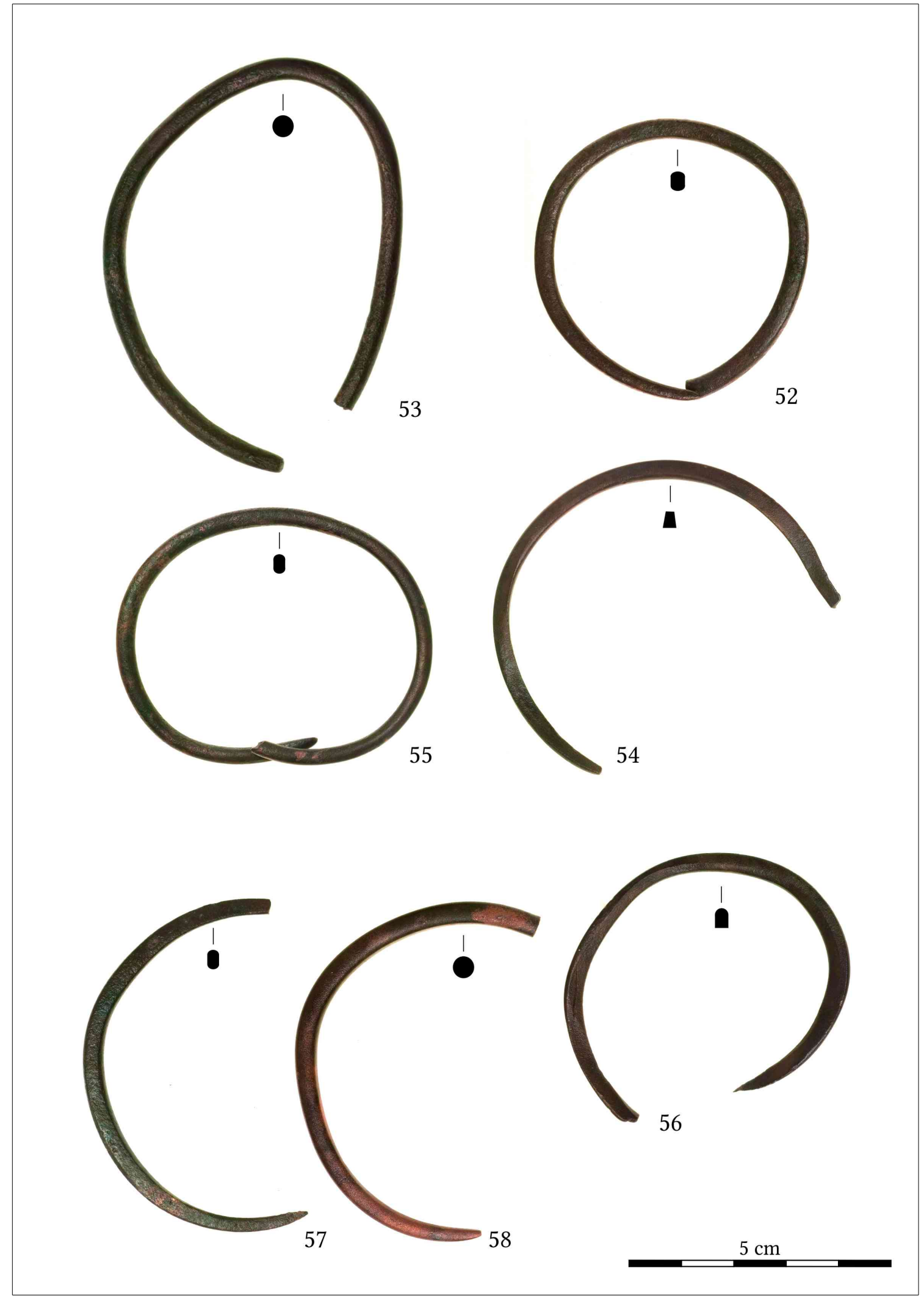

Fig. 63. 53-58. Rings with pointed-terminals. 


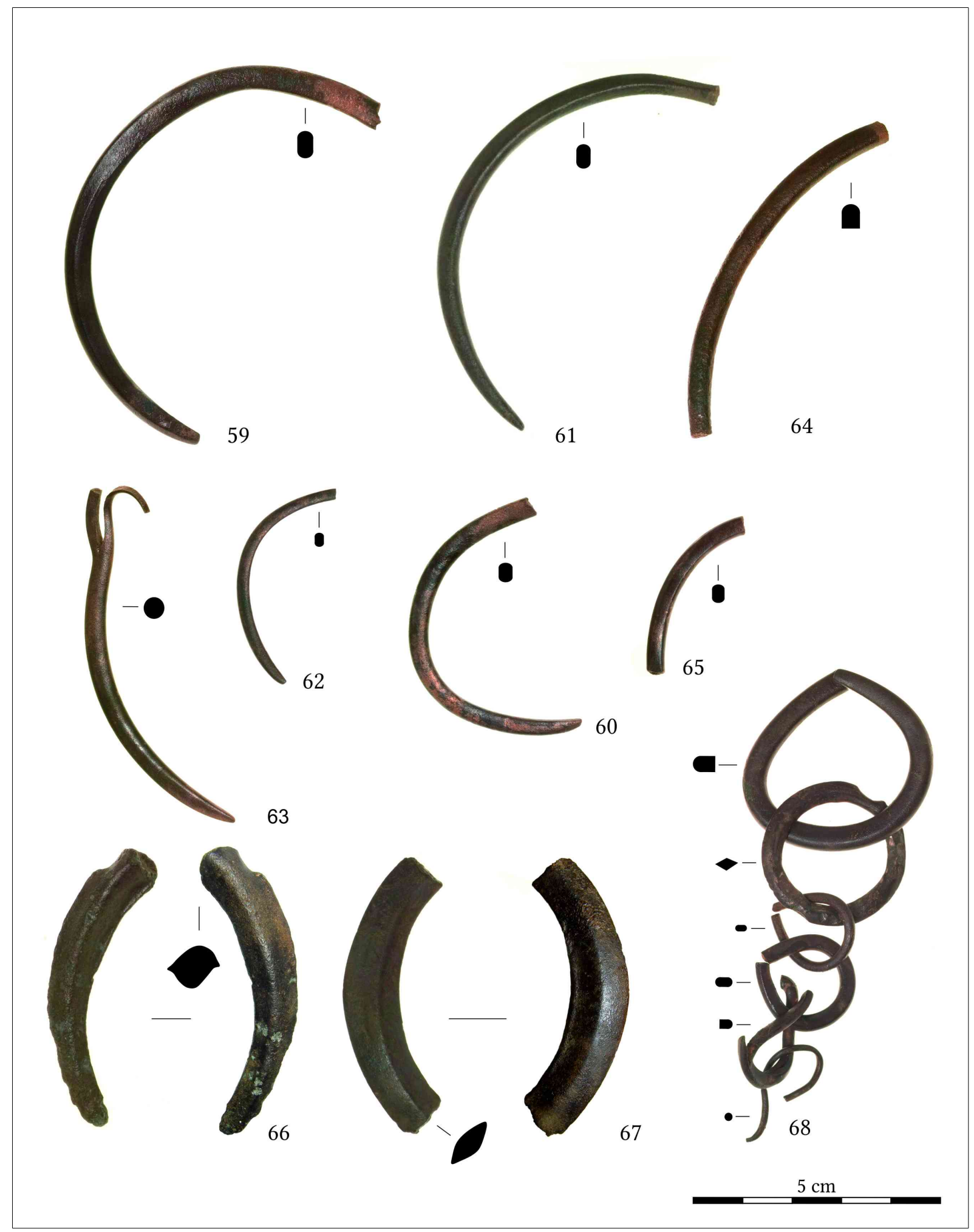

Fig. 64. 59-64. Rings with pointed-terminals 66-67. fragments of rhomboid-sectioned rings 68. chained objects. 


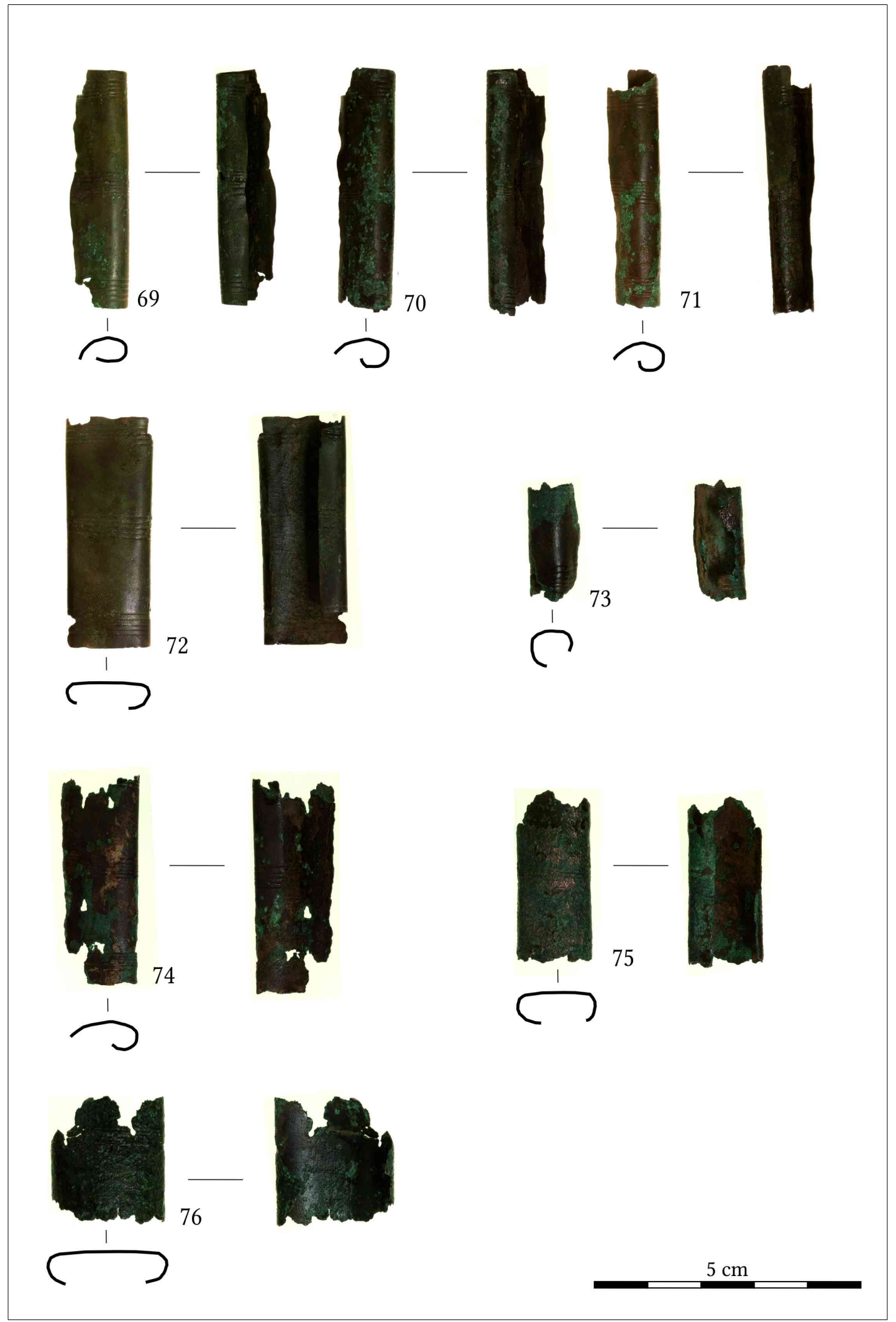

Fig. 65. 69-76. Metal sheet tubes with line decoration. 


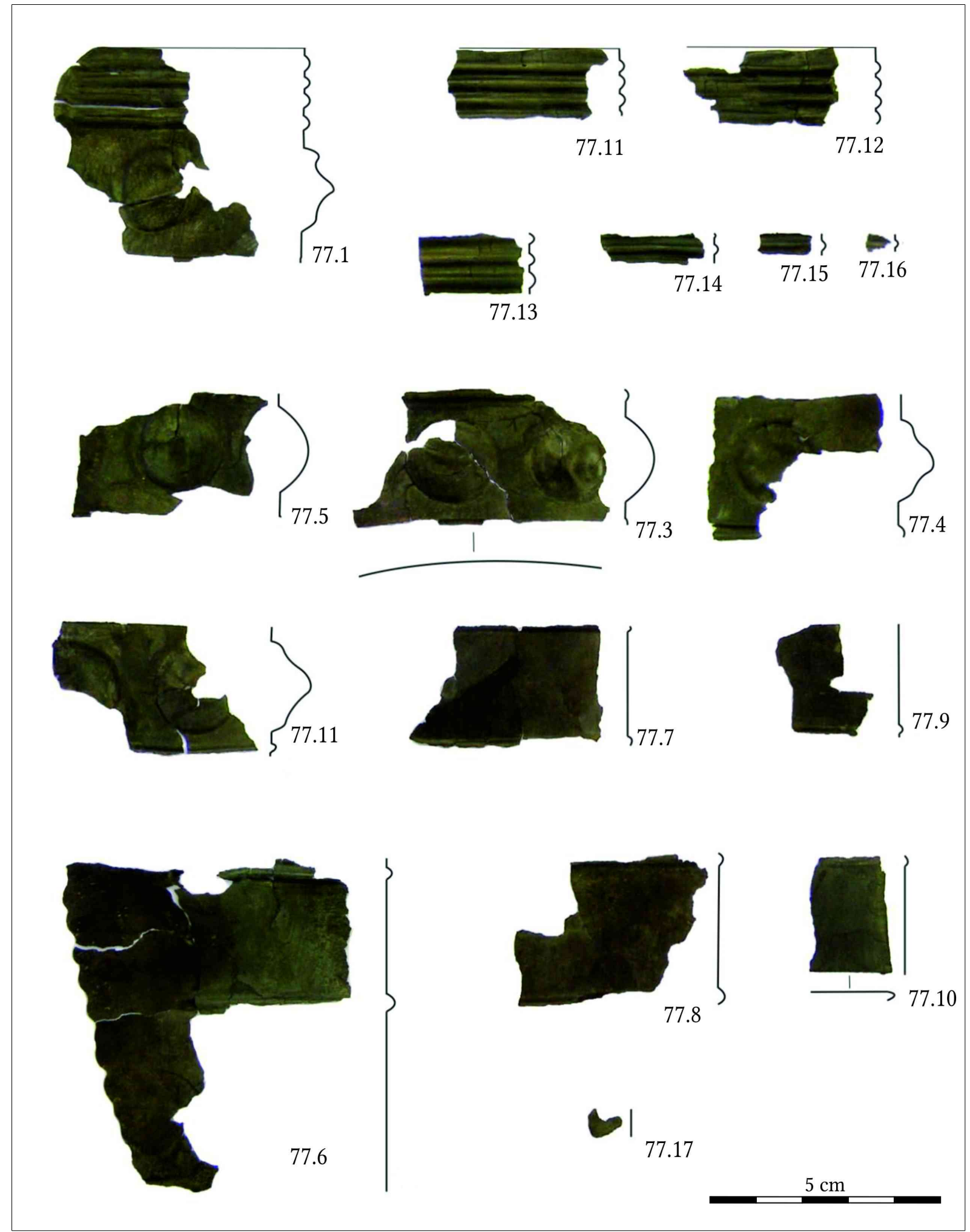

Fig. 66. 77.1-77.17. Fragments of a Žatec-Type bucket. 


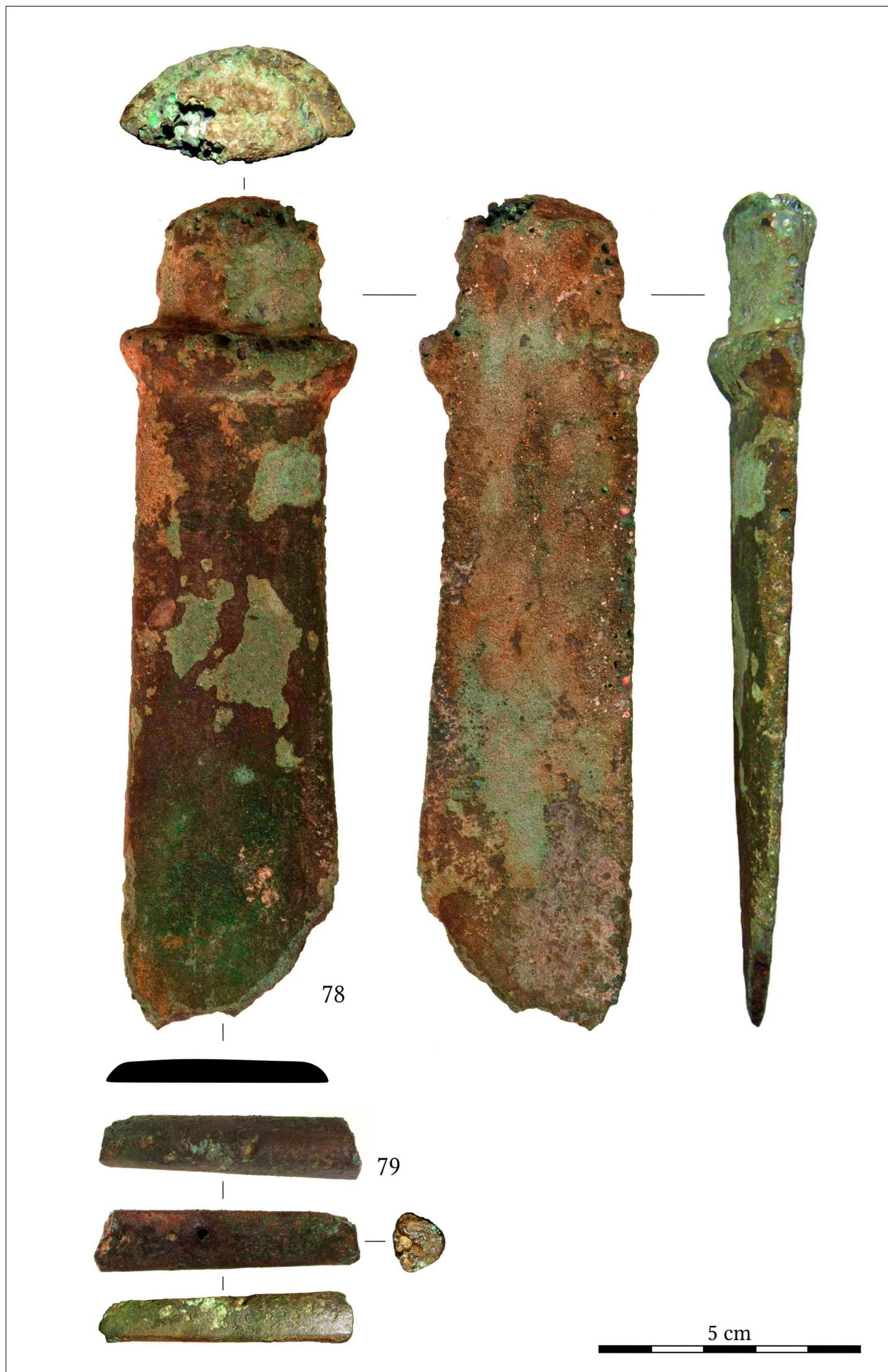

Fig. 67. 78. Axe half-form 79. Rod ingot. 


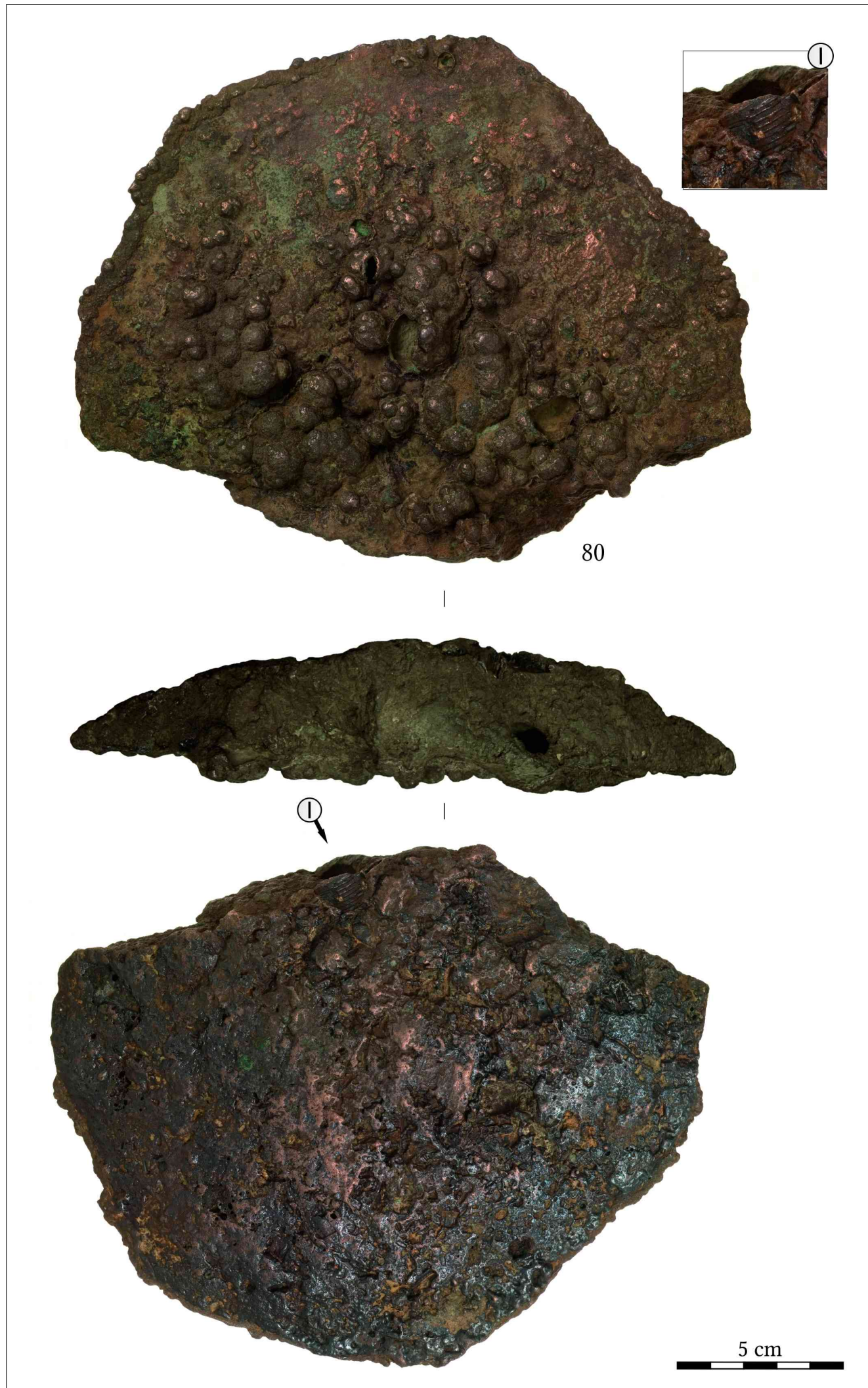

Fig. 68. 80. Fragment of a plano-convex ingot. 


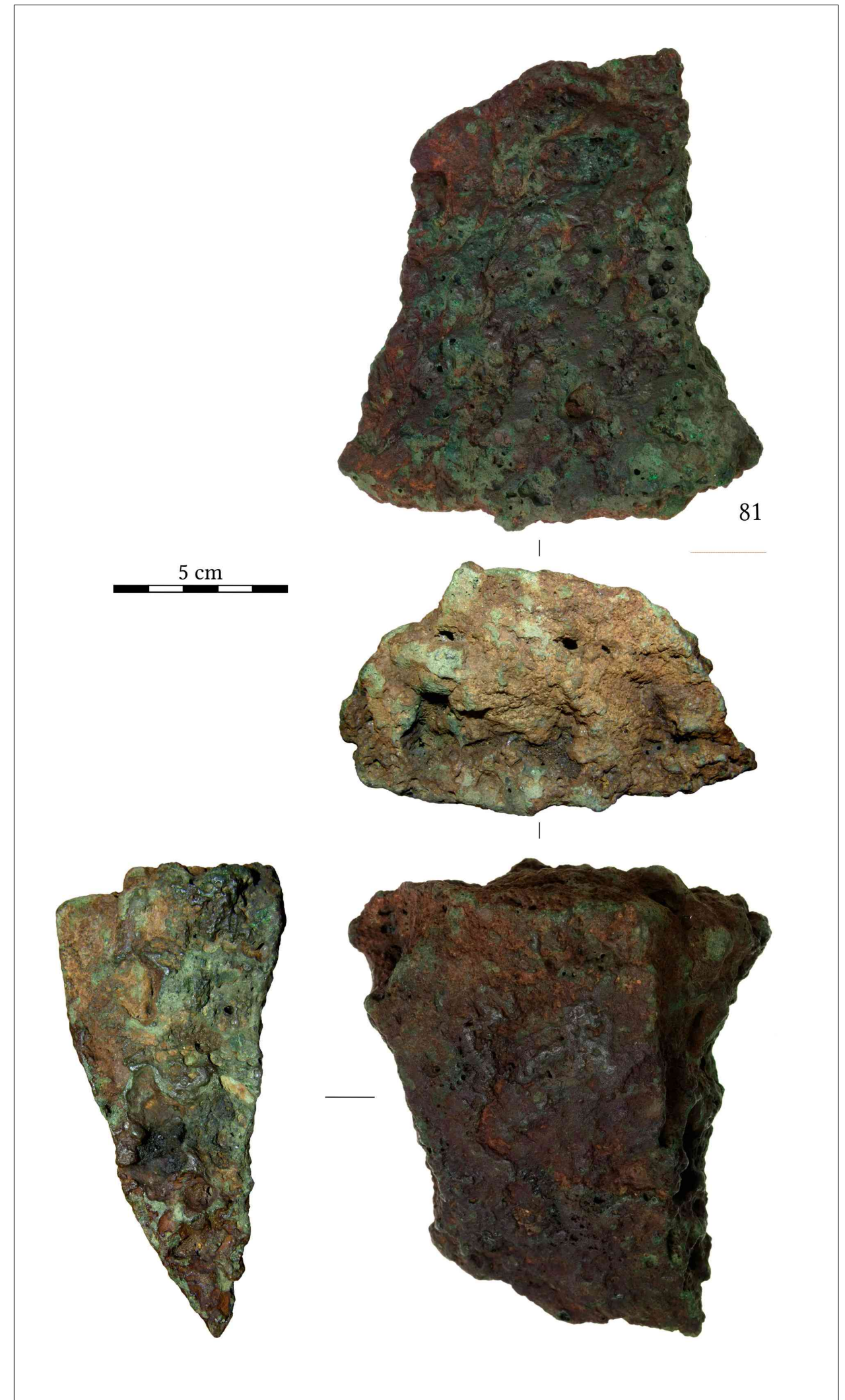

Fig. 69. 81. Fragment of a plano-convex ingot. 


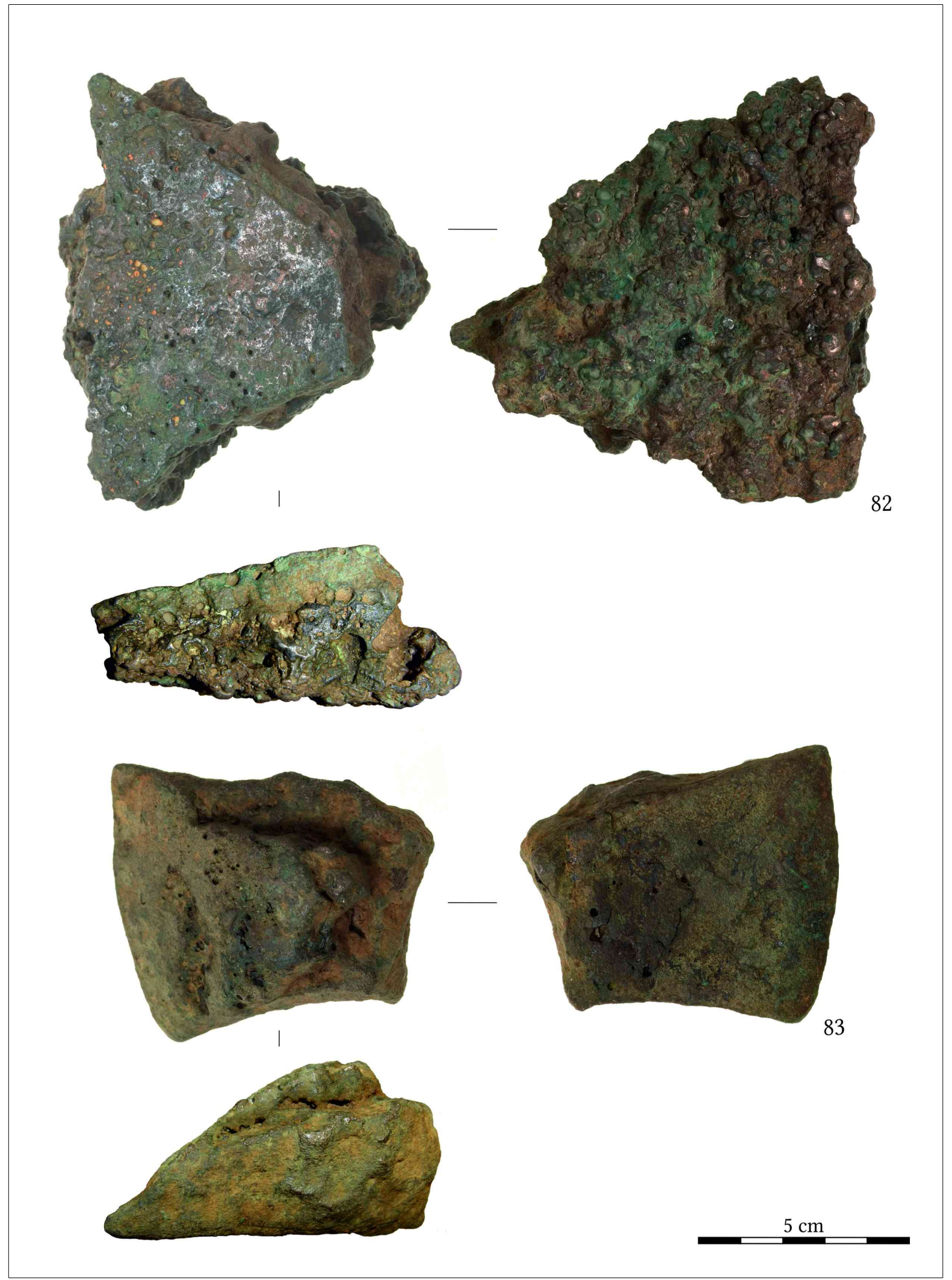

Fig. 70. 82-83. Fragments of plano-convex ingots. 


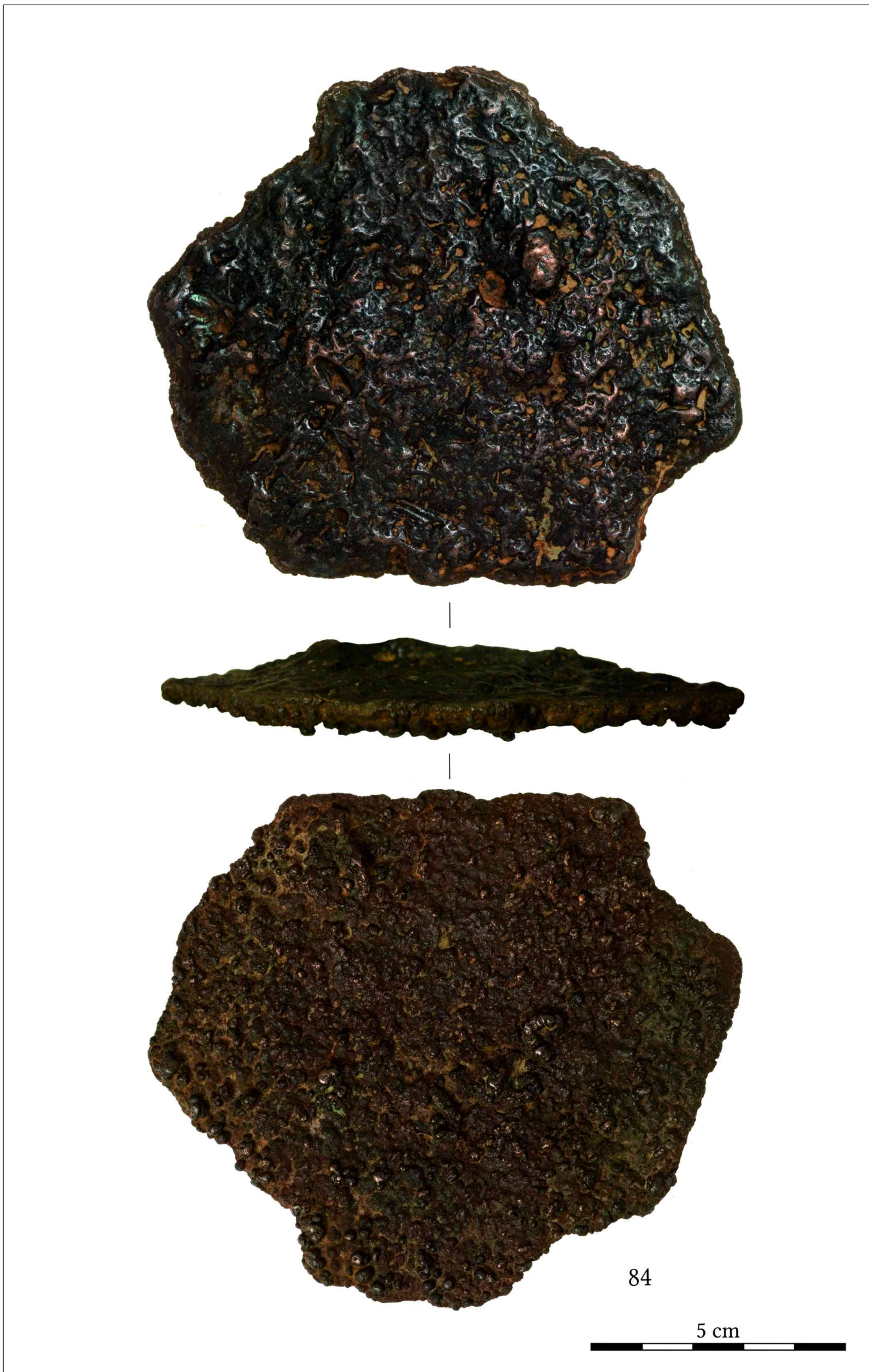

Fig. 71. 84. Plano-convex ingot. 


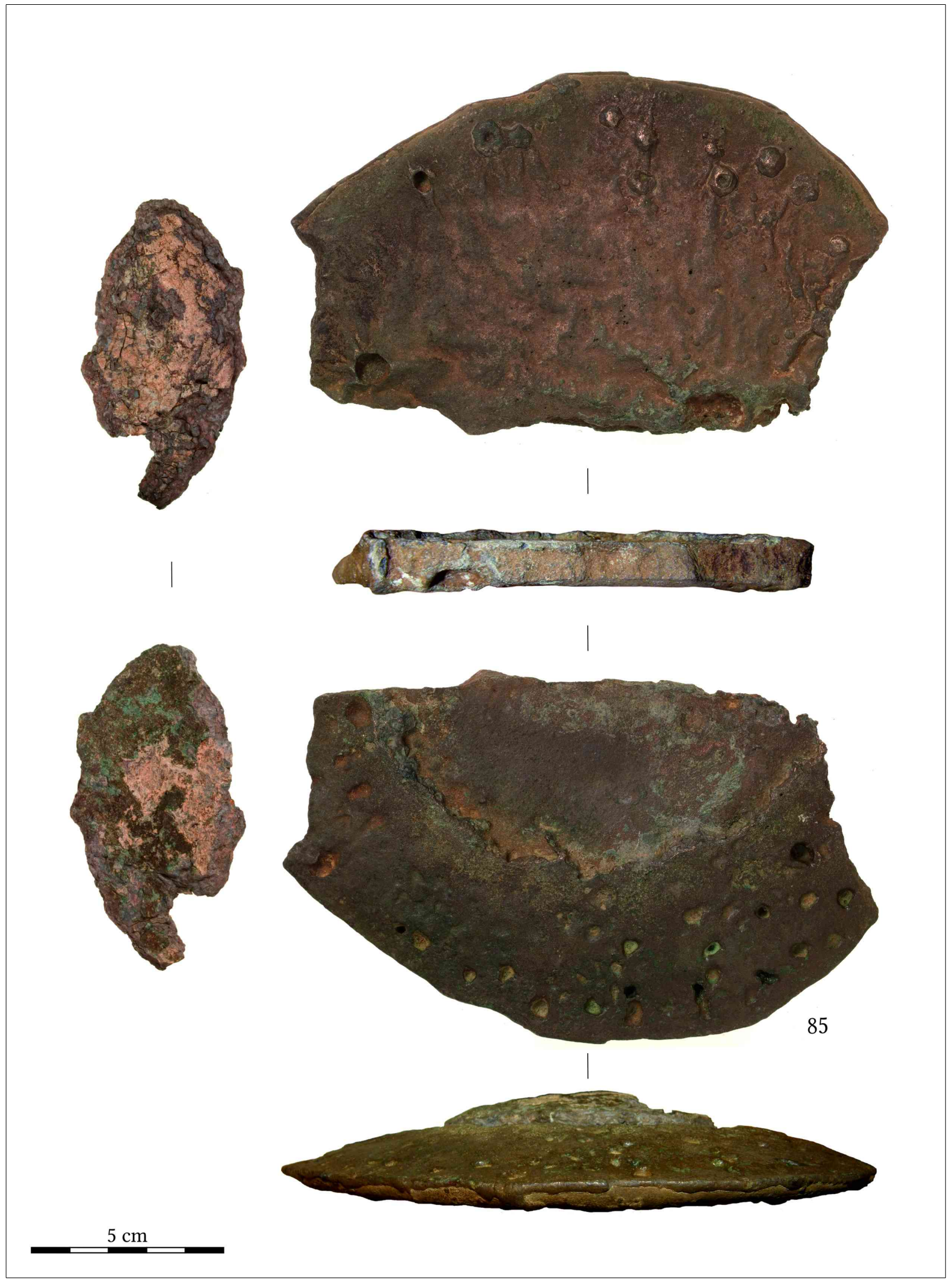

Fig. 72. 85. Fragments of a plano-convex ingot. 


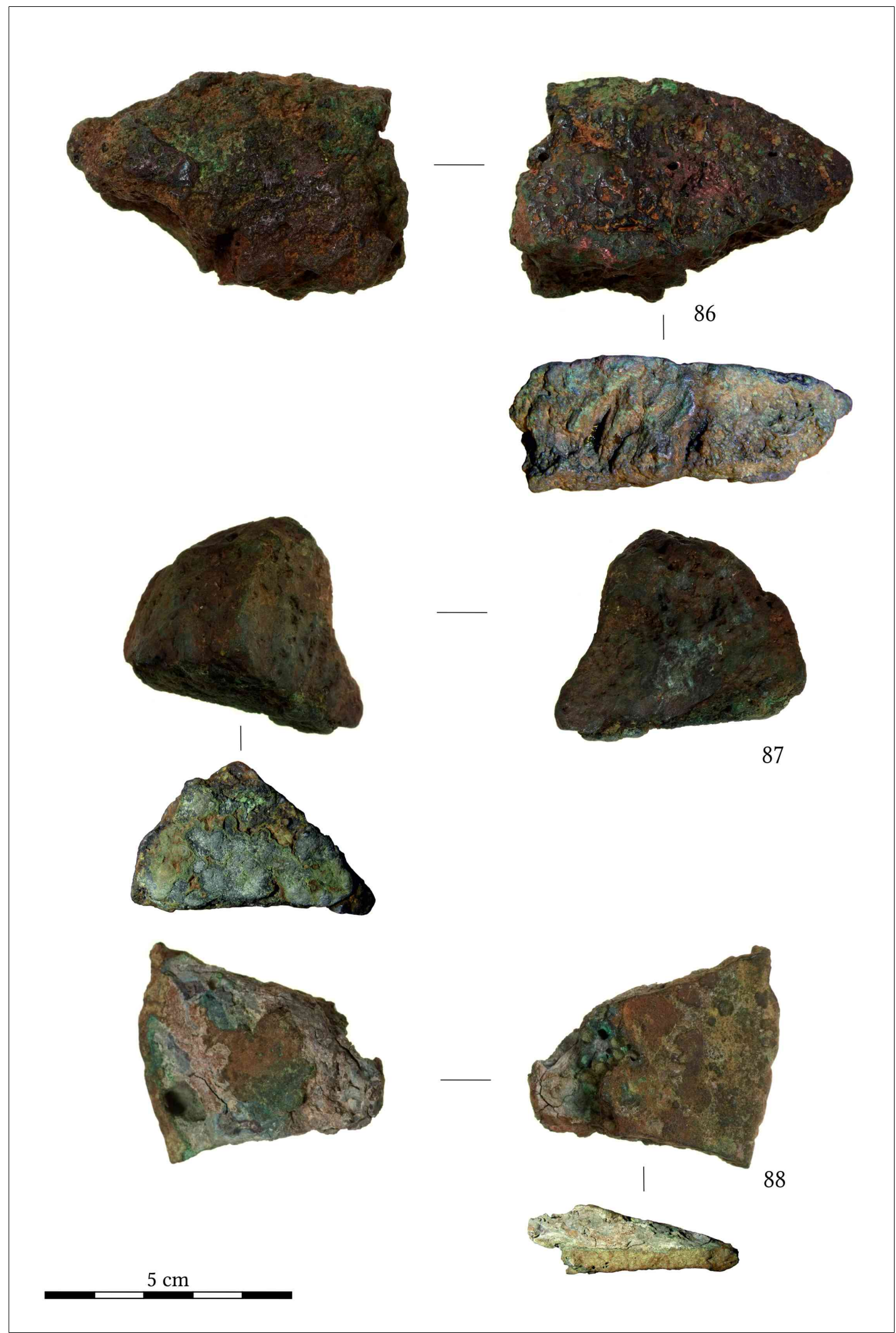

Fig. 73. 86-88. Fragments of plano-convex ingots. 


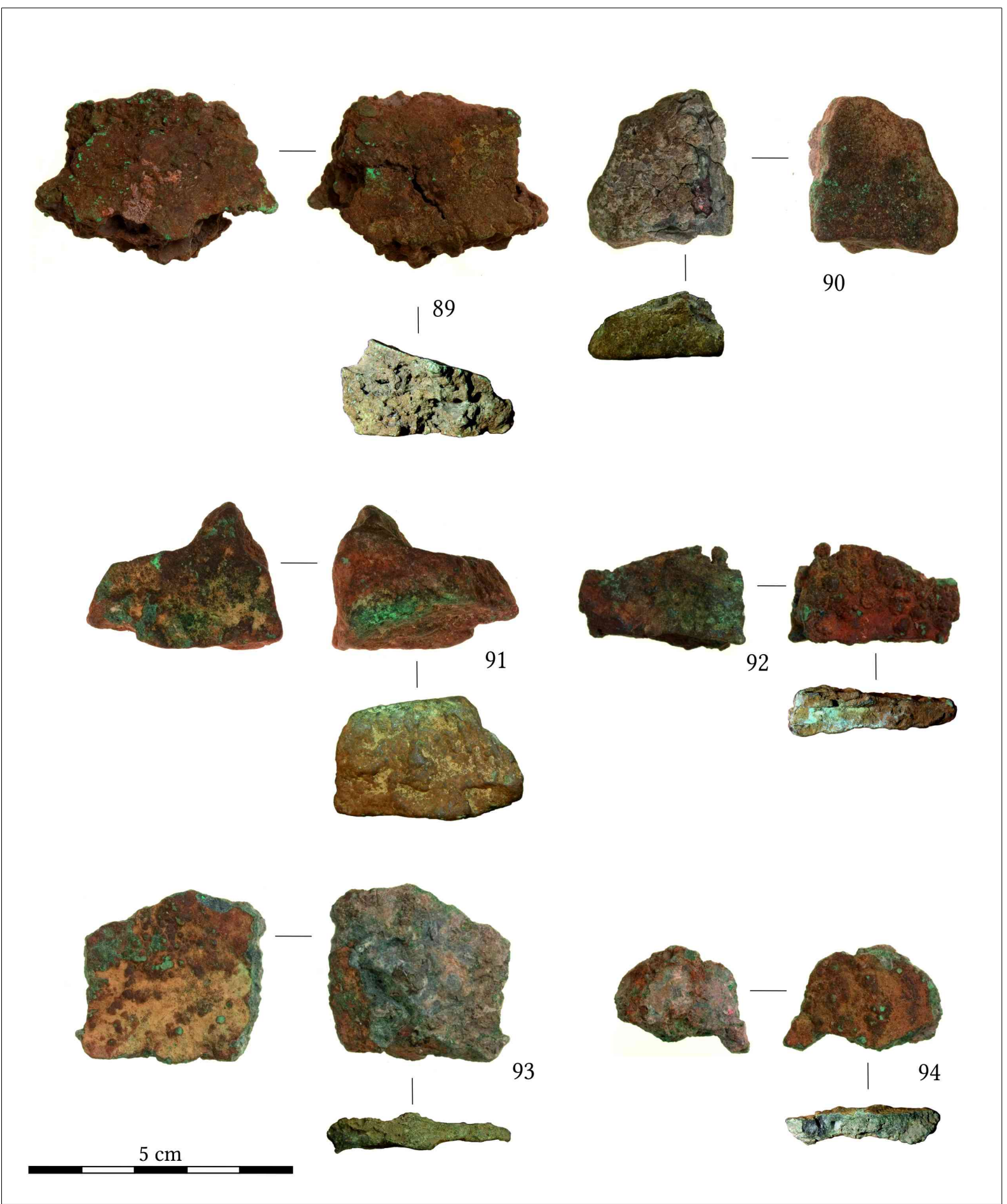

Fig. 74. 89-94. Fragments of plano-convex ingots. 


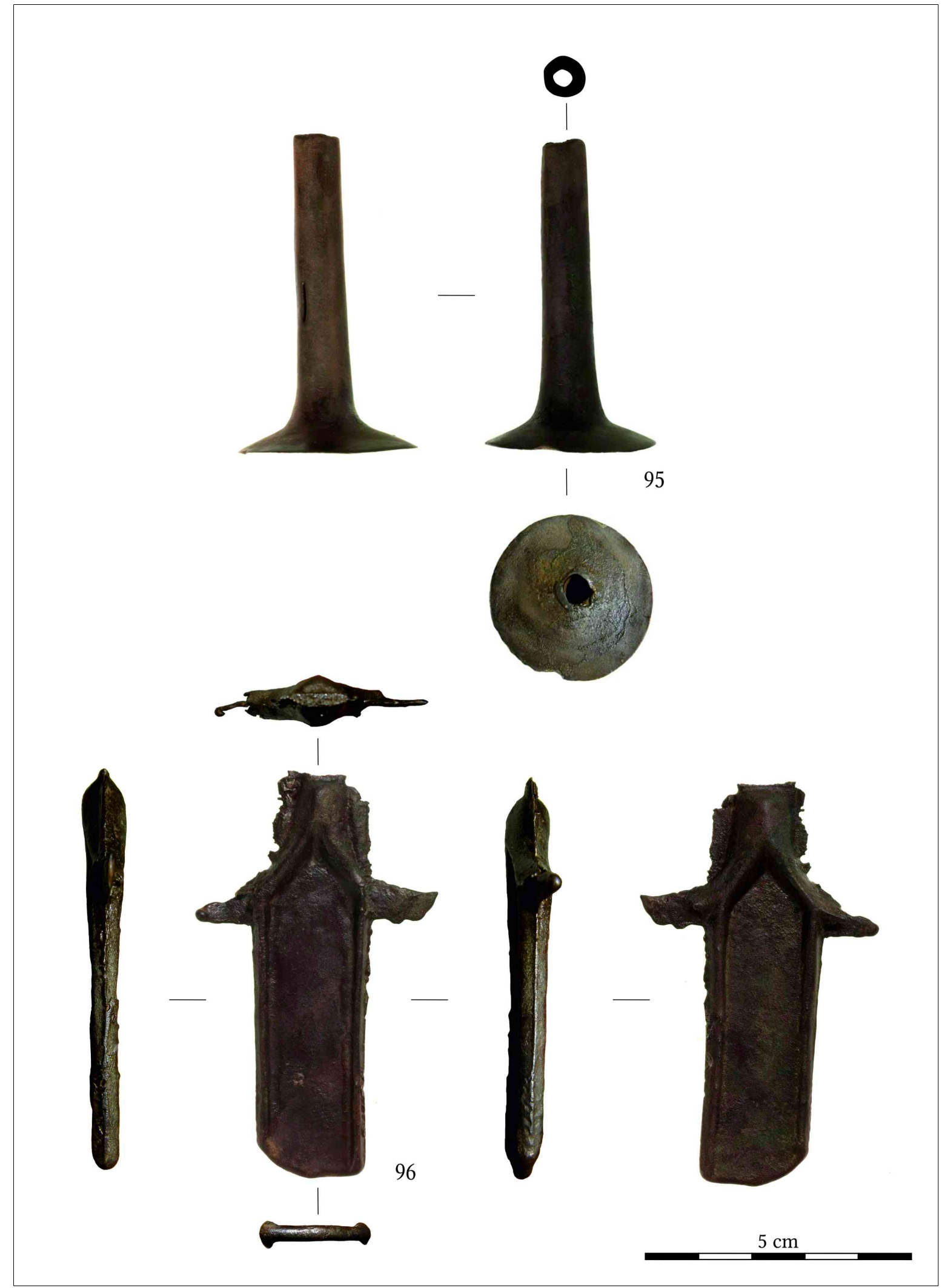

Fig. 75. 95. Tube with widened rim 96. Casting jet. 


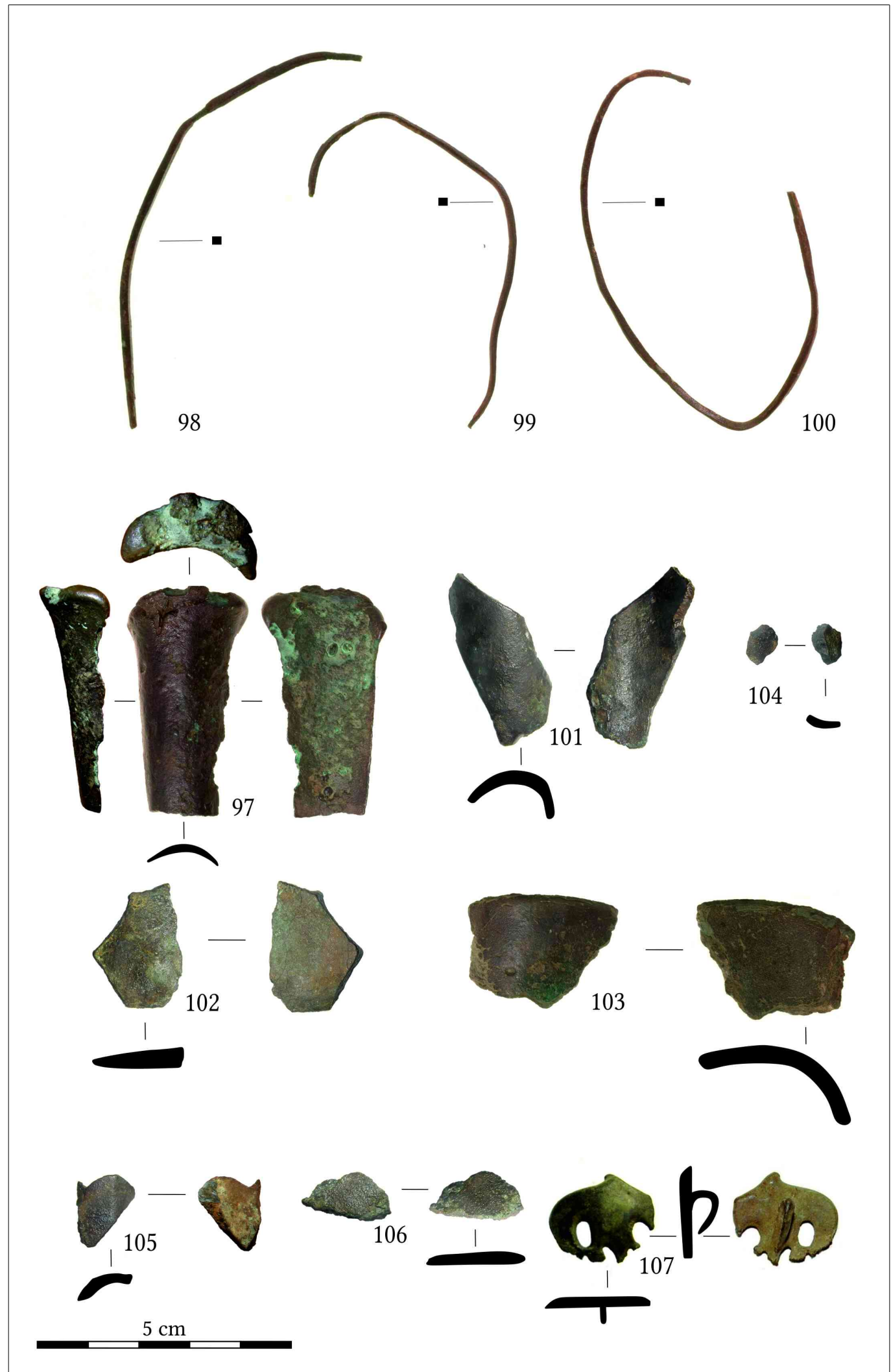

Fig. 76. 97-99. Wire fragments. 100. Casting jet. 101-106. Fragments of socketed utensils. 107. Uncassifiable object (belt hook?). 